Unclassified Source Term and

Radionuclide Data for the

Groundwater Flow and

Contaminant Transport Model of

Corrective Action Units 101 and

102: Central and Western Pahute

Mesa, Nye County, Nevada

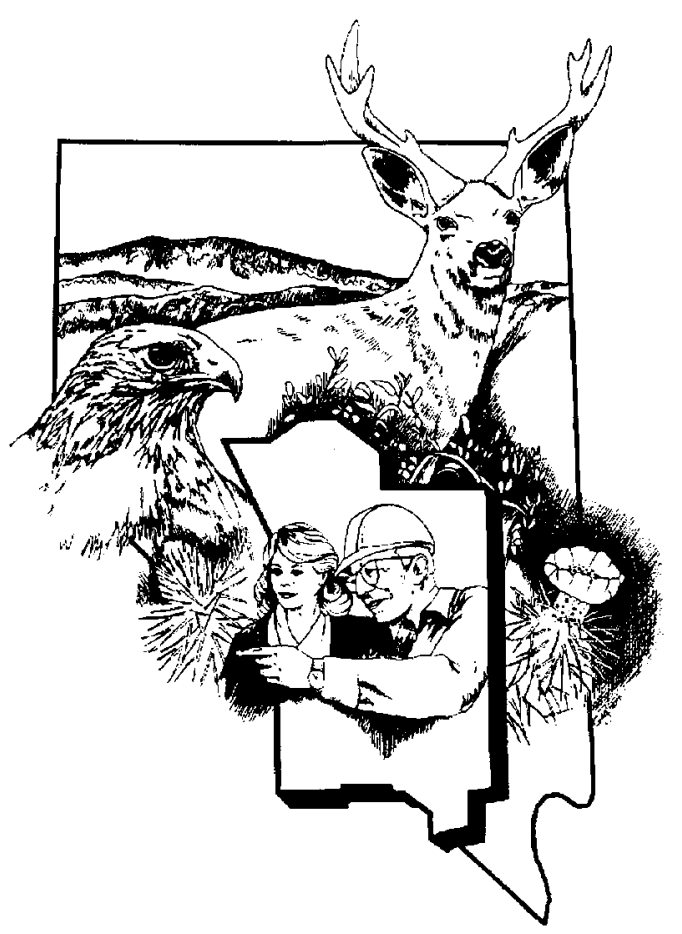

Revision No.: 0

Prepared for U.S. Department of Energy under Contract No. DE-AC52-03NA99205

Approved for public release; further dissemination unlimited. 
Available for sale to the public from:

U.S. Department of Commerce

National Technical Information Service

5301 Shawnee Road

Alexandria, VA 22312

Telephone: 800.553 .6847

Fax: 703.605.6900

E-mail:orders@ntis.gov

Online Ordering: http://www.ntis.gov/help/

ordermethods.aspx

Available electronically at http://www.osti.gov/bridge

Available for a processing fee to U.S. Department of Energy and its contractors, in paper, from:

$\underline{\text { U.S. Department of Energy }}$

Office of Scientific and Technical Information

P.O. Box 62

Oak Ridge, TN 37831-0062

Phone: 865.576 .8401

Fax: 865.576 .5728

Email: reports@adonis.osti.gov

Reference herein to any specific commercial product, process, or service by trade name, trademark, manufacturer, or otherwise, does not necessarily constitute or imply its endorsement, recommendation, or favoring by the United States Government or any agency thereof or its contractors or subcontractors 


\section{UNCLASSIFIED SOURCE TERM AND RADIONUCLIDE DATA FOR THE GROUNDWATER FLOW AND CONTAMINANT TRANSPORT MODEL OF CORRECTIVE ACTION UNITS 101 AND 102: CENTRAL AND WESTERN PAHUTE MESA, NYE COUNTY, NEVADA}

Revision No.: 0

August 2004

Stoller-Navarro Joint Venture

7710 W. Cheyenne, Bldg 3

Las Vegas, NV 89129 
UNCLASSIFIED SOURCE TERM AND RADIONUCLIDE DATA FOR THE GROUNDWATER FLOW AND CONTAMINANT TRANSPORT MODEL OF CORRECTIVE ACTION UNITS 101 AND 102:

CENTRAL AND WESTERN PAHUTE MESA, NYE COUNTY, NEVADA

Approved by: Signature Approved

Date: 8/05/04

John McCord, UGTA Project Manager

Stoller-Navarro Joint Venture 


\section{Table of Contents}

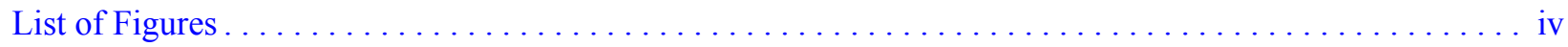

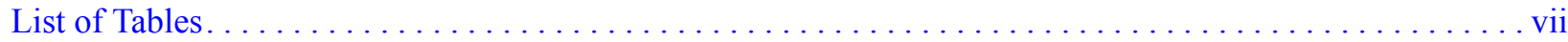

List of Acronyms and Abbreviations $\ldots \ldots \ldots \ldots \ldots \ldots \ldots \ldots \ldots \ldots \ldots \ldots \ldots \ldots \ldots \ldots \ldots \ldots \ldots \ldots \ldots \ldots \ldots$

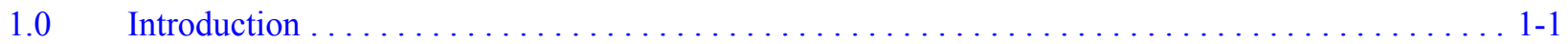

$1.1 \quad$ Site Background. . . . . . . . . . . . . . .

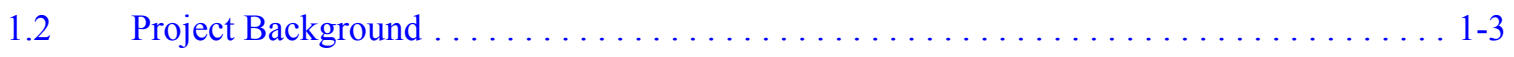

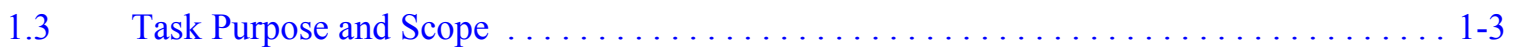

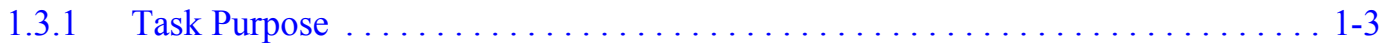

1.3.2 Scope of Work ............................... 1-4

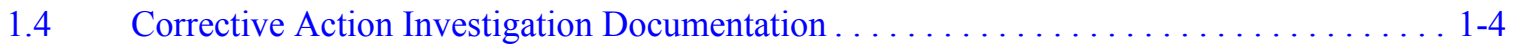

1.5 Document Organization. . . . . . . . . . . . . . . . . . . . . . . . . . . .

$2.0 \quad$ Corrective Action Unit Modeling Approach. ........................... 2-1

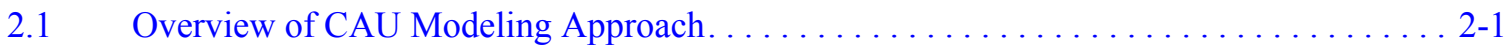

2.1.1 Selected Code. . . . . . . . . . . . . . . . . . . . . . . . . . . . . . . . . . . . . 2-2

2.1.2 Data Requirements............................... 2-3

2.2 Transport Modeling Approach and Data Requirements . . . . . . . . . . . . . . . 2-4

2.2.1 Modeling Approach . . . . . . . . . . . . . . . . . . . . . . . 2-4

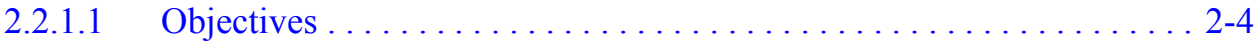

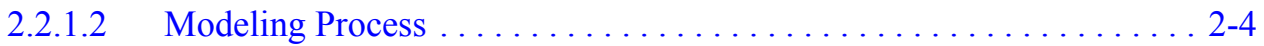

2.2.2 Data Requirements ............................. 2-6

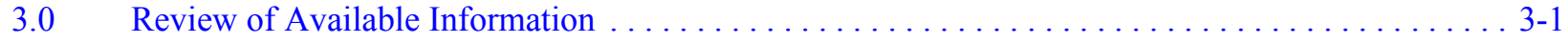

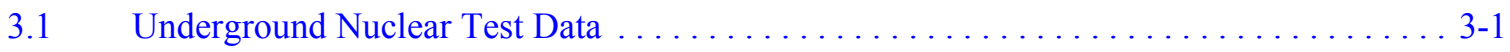

3.2 Phenomenology and Phenomenological Models ..................... 3-3

3.2.1 Phenomenology of an Underground Nuclear Explosion . . . . . . . . . . . . 3-8

3.2.2 Phenomenological Models of Underground Nuclear Test on Pahute Mesa . . . . 3-10

$3.3 \quad$ Unclassified Radionuclide Inventory. . . . . . . . . . . . . . . . . . . . . . . 3-11

3.4 Radionuclide Distribution in the Subsurface . . . . . . . . . . . . . . . . . . 3-11

3.4.1 Groundwater Sampling Data . . . . . . . . . . . . . . $\ldots \ldots \ldots \ldots$

3.4.2 Radiochemistry of Cavity Water . . . . . . . . . . . . . . . . . . 3-13

3.4.3 Radionuclide Distribution Outside the Cavity Region. . . . . . . . . . . . . . 3-14

3.4.4 Closed System Behavior . . . . . . . . . . . . . . . . . . . . . . . 3-15

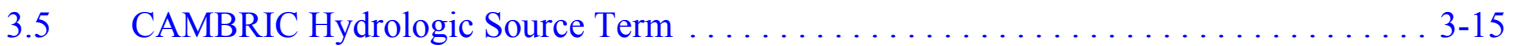

3.6 Simplified Frenchman Flat Hydrologic Source Term. ................... 3-16

3.7 CHESHIRE Hydrologic Source Term Model . . . . . . . . . . . . . . . . . 3-17 


\section{Table of Contents (Continued)}

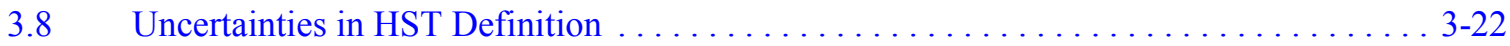

3.9 TYBO-BENHAM Model. . . . . . . . . . . . . . . . . . . . . . . . . . . . . . . . . 3-23

$4.0 \quad$ Source Term Process Model Simplifications $\ldots \ldots \ldots \ldots \ldots \ldots \ldots \ldots \ldots \ldots \ldots \ldots \ldots \ldots$

$4.1 \quad$ Simplified Source Term Model . . . . . . . . . . . . . . . . . . . . . . 4-1

4.1.1 Components of the Simplified Source Term Model . . . . . . . . . . . . . . 4 4-2

4.1.1.1 Dimensions of the Source Regions . . . . . . . . . . . . . . . . . 4-2

4.1.1.2 Volumes and Porosities of the Source Regions . . . . . . . . . . . . . . 4-4

$4.1 .2 \quad$ Hydrologic Model . . . . . . . . . . . . . . . . . . . . . . 4-4

4.1.3 SSM Radionuclide Inventory and Its Partitioning . . . . . . . . . . . . $4-7$

4.1.4 Sorption .................................. 4-10

4.1.5 Glass Dissolution .............................. 4-14

4.2 Mass Fluxes for Tracer Radionuclides. . . . . . . . . . . . . . . . . . . 4-15

4.2.1 Analytic Solution . . . . . . . . . . . . . . . . . . . . . . . . . . . . . 4-16

4.2.2 Comparison to ${ }^{14} \mathrm{C}$ Mass Flux From Process Model . . . . . . . . . . . . . . . 4-17

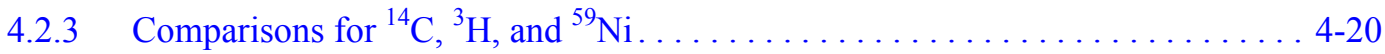

$4.3 \quad$ Mass Fluxes for Sorbed Radionuclides . . . . . . . . . . . . . . . . . . . . . . . 4-23

4.3.1 Initial Comparisons for Sorbed Radionuclides . . . . . . . . . . . . . . . . . 4-23

$4.4 \quad$ Recommendations . . . . . . . . . . . . . . . . . . . . . . . . . . . . . . . . 4-28

$5.0 \quad$ Unclassified Hydrologic Source Term Calculation Procedure $\ldots \ldots \ldots \ldots \ldots \ldots \ldots \ldots \ldots \ldots . \ldots \ldots$

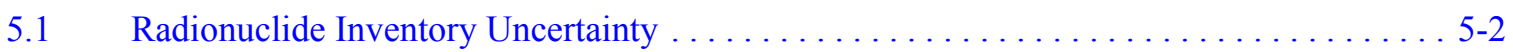

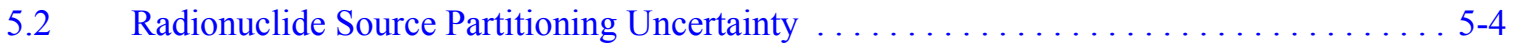

5.3 Uncertainty in Hydrologic Setting of Tests . . . . . . . . . . . . . . . . . . 5-5

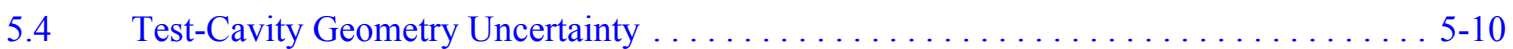

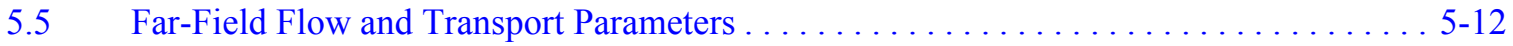

5.6 Proposed Approach to Applying the PM SSM . . . . . . . . . . . . . . . . . . 5 5-12

$6.0 \quad$ Evaluation of Radionuclide Data . . . . . . . . . . . . . . .

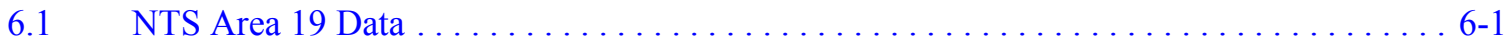

6.1.1 ALMENDRO (U19v) Sampling Data . . . . . . . . . . . . . . . . . . . . 6-1

6.1.2 CAMEMBERT Test (U19q) .......................... 6-3

6.1 .3 Water Supply Well UE-19c WW . . . . . . . . . . . . . . . . . 6-4

$6.2 \quad$ NTS Area 20 Data . . . . . . . . . . . . . . . . . . . . . . . . . . 6

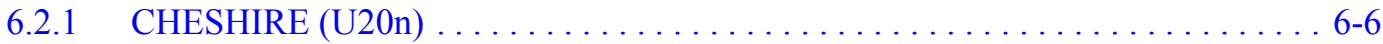

6.2 .2 TYBO (U20y)/BENHAM (U20c) . . . . . . . . . . . . . . . . 6-9

$6.2 .3 \quad$ ER-20-6 Well Cluster. . . . . . . . . . . . . . . . . . . . . . 6-14

6.2 .4 Water Supply Well U-20 WW ......................... 6-16

$6.2 .5 \quad$ Well PM-1 . . . . . . . . . . . . . . . . . . . . . . . . . . . . . 6-18 


\section{Table of Contents (Continued)}

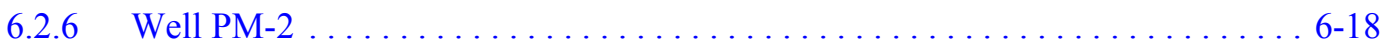

6.3 Offsite Radionuclide Data . . . . . . . . . . . . . . . . . . . . . . . . . 6-19

6.3.1 Oasis Valley Discharge Area Sampling Data .................. 6-20

6.3.2 Pahute Mesa CAI Wells . . . . . . . . . . . . . . . . . . . . . . . 6 6-20

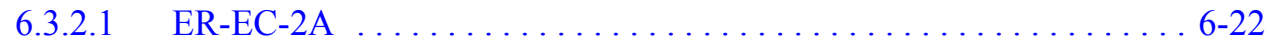

$6.3 .2 .2 \quad$ ER-EC-8 . . . . . . . . . . . . . . . . . . . . 6-23

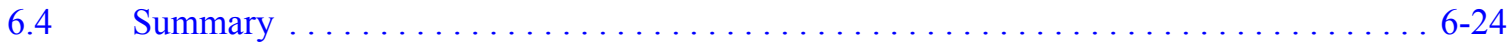

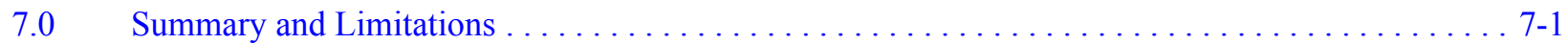

$8.0 \quad$ References . . . . . . . . . . . . . . . . .

\section{Appendix A - Hydrostratigraphic Model Supporting Information}

A.1.0 Description of the Pahute Mesa-Oasis Valley Model Layers . . . . . . . . . . . . . . . . . . . . . . . . A-1

A.2.0 References . . . . . . . . . . . . . . . . . . . . . . . . . . . . . . . . . . . . . . . . . . . A-1

\section{Appendix B - Summary Description of GoldSim ${ }^{\circledR}$ Software}

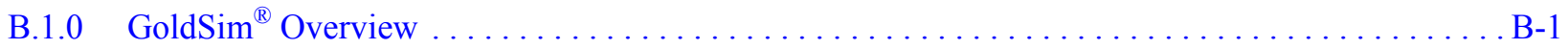

B.2.0 References . . . . . . . . . . . . . . . . . . . . . . . . . . . . . . . . . . . . . B-2

\section{Appendix C - Description of GeoChem Database}

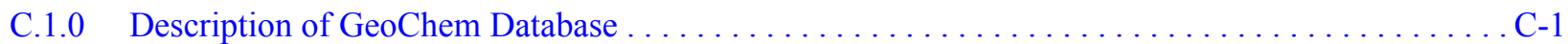

C.2.0 Reference. . . . . . . . . . . . . . . . . . . . . . . . . . . . . . . . . . . C-1

\section{Appendix D - Comparison of Mass Fluxes from the SSM and Particle Model} (Process Model) for 37 Radionuclides in the CHESHIRE Inventory

D.1.0 Comparisons of Mass Flux from the SSM with the Process (Particle) Model for Tracer Radionuclides . . . . . . . . . . . . . . . . . . . . . . . . . . . .

D.2.0 Comparisons of Mass Flux from the SSM with the Process (Particle) Model for Sorbing Radionuclides with a Fracture Spacing of 1.5 per Meter. . . . . . . . . . . . . . . D-9 


\section{List of Figures}

Number

1-1 Location of the Pahute Mesa Corrective Action Units . . . . . . . . . . . . . . . . $1-2$

1-2 Investigation and PM-OV Areas for the Pahute Mesa Corrective Action Units. . . . . . . . 1-5

3-1 Location of Underground Nuclear Tests on Pahute Mesa $\ldots \ldots \ldots \ldots \ldots \ldots \ldots \ldots \ldots .2$

4-1 Schematic Diagram of the Source Term Regions in the

CHESHIRE Process-Level Model and in the SSM. . . . . . . . . . . . . . . . . 4-3

4-2 Hydrologic Properties for the Process Model of CHESHIRE (Pawloski et al., 2002) . . . . . . 4-6

4-3 Schematic of the SSM Conceptual Model for the CHESHIRE TEST . . . . . . . . . . . . 4-7

4-4 Breakthrough Curves from the Process Model for ${ }^{14} \mathrm{C} \ldots \ldots \ldots \ldots \ldots \ldots \ldots . .4 .18$

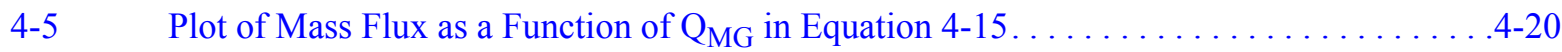

4-6 Comparison of ${ }^{14} \mathrm{C}$ Exit Mass Fluxes from the Process Model with the SSM. . . . . . . . . .4-21

4-7 Comparison of ${ }^{3} \mathrm{H}$ Mass Fluxes from the Process Model with the SSM. . . . . . . . . . . . 4-21

4-8 Comparison of ${ }^{59}$ Ni Mass Fluxes from the Process Model with the SSM. . . . . . . . . . 4-22

4-9 Comparison of ${ }^{234} \mathrm{U}$ Mass Fluxes from the Process Model with the SSM. . . . . . . . . . . .4-24

4-10 Comparison of ${ }^{237} \mathrm{~Np}$ Mass Fluxes from the Process Model with the SSM. . . . . . . . . . .4-24

4-11 Comparison of ${ }^{239} \mathrm{Pu}$ Mass Fluxes from the Process Model with the SSM............4-25

4-12 Comparison of ${ }^{151}$ Sm Mass Fluxes from the Process Model with the SSM. . . . . . . . . 4-25

4-13 Comparison of ${ }^{151}$ Am Mass Fluxes from the Process Model with the SSM............4-26

4-14 Comparison of ${ }^{151}$ Sm Mass Fluxes from the Process Model with the SSM. . . . . . . . . . .4-27

4-15 Comparison of ${ }^{241}$ Am Mass Fluxes from the Process Model with the SSM... . . . . . . . . 4-27

6-1 Groundwater Sampling Location within the Pahute Mesa-Oasis Valley Area . . . . . . . . . . . 6-2

D.1-1 Comparison of ${ }^{3} \mathrm{H}$ Exit Mass Fluxes from the Process Model with the SSM . . . . . . . . D-1

D.1-2 Comparison of ${ }^{14} \mathrm{C}$ Exist Mass Fluxes from the Process Model with the SSM . . . . . . . . D-2

D.1-3 Comparison of ${ }^{36} \mathrm{CI}$ Exist Mass Fluxes from the Process Model with the SSM ........ D-2

D.1-4 Comparison of ${ }^{39} \mathrm{C}$ Ar Exit Mass Fluxes from the Process Model with the SSM . . . . . . . D-3

D.1-5 Comparison of ${ }^{59} \mathrm{Ni}$ Exit Mass Fluxes from the Process Model with the SSM . . . . . . . . D-3

D.1-6 Comparison of ${ }^{63} \mathrm{Ni}$ Exit Mass Fluxes from the Process Model with the SSM . . . . . . . . D-4

D.1-7 Comparison of ${ }^{85} \mathrm{Kr}$ Exit Mass Fluxes from the Process Model with the SSM . . . . . . . . D-4

D.1-8 Comparison of ${ }^{93} \mathrm{Zr}$ Exit Mass Fluxes from the Process Model with the SSM . . . . . . . D-5

D.1-9 Comparison of ${ }^{93} \mathrm{Nb}$ Exit Mass Fluxes from the Process Model with the SSM. . . . . . . D-5

D.1-10 Comparison of ${ }^{94} \mathrm{Nb}$ Exit Mass Fluxes from the Process Model with the SSM . . . . . . . . D-6

D.1-11 Comparison of ${ }^{99}$ Tc Exit Mass Fluxes from the Process Model with the SSM . . . . . . . D-6 


\section{List of Figures (Continued)}

Number

D.1-12 Comparison of ${ }^{107}$ Pd Exit Mass Fluxes from the Process Model with the SSM . . . . . . . D-7

D.1-13 Comparison of ${ }^{121}$ Sn Exit Mass Fluxes from the Process Model with the SSM . . . . . . . D-7

D.1-14 Comparison of ${ }^{126}$ Sn Exit Mass Fluxes from the Process Model with the SSM . . . . . . . D-8

D.1-15 Comparison of ${ }^{129}$ I Exit Mass Fluxes from the Process Model with the SSM . . . . . . . . D-8

D.2-1 Comparison of ${ }^{41}$ Ca Exit Mass Fluxes from the Process Model with the SSM . . . . . . . . D D-9

D.2-2 Comparison of ${ }^{90} \mathrm{Sr}$ Exit Mass Fluxes from the Process Model with the SSM . . . . . . . D-10

D.2-3 Comparison of ${ }^{135}$ Cs Exit Mass Fluxes from the Process Model with the SSM . . . . . . D-10

D.2-4 Comparison of ${ }^{137}$ Cs Exit Mass Fluxes from the Process Model with the SSM . . . . . . D D-11

D.2-5 Comparison of ${ }^{151}$ Sm Exit Mass Fluxes from the Process Model with the SSM. ...... D-11

D.2-6 Comparison of ${ }^{150}$ Eu Exit Mass Fluxes from the Process Model with the SSM . . . . . . D-12

D.2-7 Comparison of ${ }^{152}$ Eu Exit Mass Fluxes from the Process Model with the SSM ....... D-12

D.2-8 Comparison of ${ }^{154}$ Eu Exit Mass Fluxes from the Process Model with the SSM ....... D-13

D.2-9 Comparison of ${ }^{166}$ Ho Exit Mass Fluxes from the Process Model with the SSM . . . . . . D D-13

D.2-10 Comparison of ${ }^{232} \mathrm{U}$ Exit Mass Fluxes from the Process Model with the SSM ........ D-14

D.2-11 Comparison of ${ }^{233} \mathrm{U}$ Exit Mass Fluxes from the Process Model with the SSM . . . . . . . . D-14

D.2-12 Comparison of ${ }^{234} \mathrm{U}$ Exit Mass Fluxes from the Process Model with the SSM . . . . . . . D - 15

D.2-13 Comparison of ${ }^{235} \mathrm{U}$ Exit Mass Fluxes from the Process Model with the SSM ........ D-15

D.2-14 Comparison of ${ }^{236} \mathrm{U}$ Exit Mass Fluxes from the Process Model with the SSM ........ D-16

D.2-15 Comparison of ${ }^{238} \mathrm{U}$ Exit Mass Fluxes from the Process Model with the SSM . . . . . . . D-16

D.2-16 Comparison of ${ }^{237} \mathrm{~Np}$ Exit Mass Fluxes from the Process Model with the SSM . . . . . . . D-17

D.2-17 Comparison of ${ }^{238} \mathrm{Pu}$ Exit Mass Fluxes from the Process Model with the SSM . . . . . . . D-17

D.2-18 Comparison of ${ }^{239} \mathrm{Pu}$ Exit Mass Fluxes from the Process Model with the SSM ....... D-18

D.2-19 Comparison of ${ }^{240} \mathrm{Pu}$ Exit Mass Fluxes from the Process Model with the SSM . . . . . . D-18

D.2-20 Comparison of ${ }^{241} \mathrm{Pu}$ Exit Mass Fluxes from the Process Model with the SSM . . . . . . . D-19

D.2-21 Comparison of ${ }^{241}$ Am Exit Mass Fluxes from the Process Model with the SSM ....... D-19

D.2-22 Comparison of ${ }^{244} \mathrm{Cm}$ Exit Mass Fluxes from the Process Model with the SSM. . . . . . . D-20 


\section{List of Tables}

Number

Title

Page

3-1 Largest Underground Nuclear Tests on Pahute Mesa. . . . . . . . . . . . . . . . 3-3

3-2 Underground Shaft Nuclear Tests Conducted in Central Pahute Mesa (CAU 101)...........3-4

3-3 Underground Shaft Nuclear Tests Conducted in Western Pahute Mesa (CAU 102) . . . . . . . . 3-7

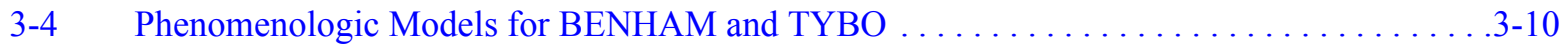

3-5 Radionuclide Inventory for Areas 19 and 20 of the Nevada Test Site . . . . . . . . . . . . . 3-12

3-6 Estimated Accuracies for Individual Nuclides in the Various Groups of Radionuclides. . . . . 3-13

3-7 Radionuclides Used in the CHESHIRE Hydrologic Source Term Model . . . . . . . . . . . . . 3-20

4-1 Volume, Porosity, and Pore Volume of Source Regions . . . . . . . . . . . . . . . . . . . 4-4

4-2 Initial Inventory and Distribution of Radionuclides for the Averaged Source Term for CHESHIRE (Pawloski et al. 2002, Table 4.3) . . . . . . . . . . . 4-8

4-3 Average Log Retardation Ratios for Heterogeneous Mineral Distributions

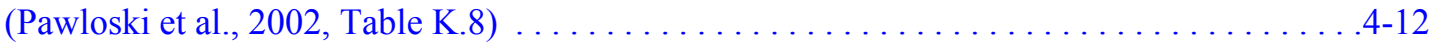

4-4 Definition of the Discrete Distribution for the Retardation Ratio of Americium in the Fracture Lining . . . . . . . . . . . . . . . . . . . . . . 43

4-5 Digitized Temperature Time History

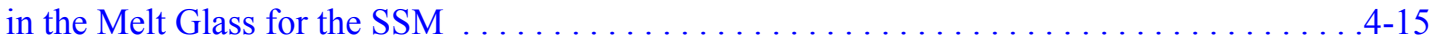

4-6 Estimate of $\mathrm{Q}_{\mathrm{EV}}$ Based on Peak Mass Fluxes for ${ }^{14} \mathrm{C} \ldots \ldots \ldots \ldots \ldots \ldots \ldots \ldots .4 .18$

4-7 Estimate of $\mathrm{Q}_{\mathrm{MG}}$ Based on Mass Fluxes at 1,000 Years for ${ }^{14} \mathrm{C} \ldots \ldots \ldots \ldots \ldots \ldots \ldots .4 .19$

5-1 Total and Average Radionuclide Inventory for Areas 19 and 20 of the Nevada Test Site. . . . .5-3

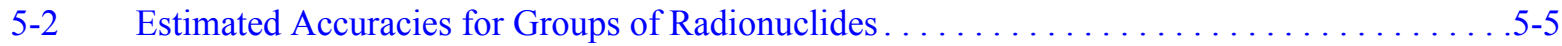

5-3 Summary of Radionuclides with Total Inventory (Curies) and Partitioning Percentages . . . . . 5-6

5-4 Probabilistic Distributions for Melt Glass/Exchange Volume Partitioning Coefficients in Terms of Melt Glass Fraction. . . . . . . . . . . . . . . . .5-7

5-5 Underground Shaft Nuclear Tests in Area 19 Classified by HSU Type. . . . . . . . . . . . . .5-8

5-6 Underground Shaft Nuclear Tests in Area 20 Classified by HSU Type. . . . . . . . . . . . . . .5-9

5-7 Summary of HSU Categories for Underground Nuclear Tests $\ldots \ldots \ldots \ldots \ldots \ldots \ldots . .11$

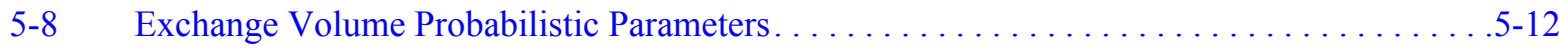

5-9 Far-Field Flow Parameters . . . . . . . . . . . . . . . . . . . . . . . . . . . . . . . 5-13

6-1 Radionuclides in Groundwater at ALMENDRO (Well U-19v PS-1 D) . . . . . . . . . . . .6-3

6-2 Average Annual Groundwater Activity Data for Well UE-19c WW from NTS Environmental Monitoring Program . . . . . . . . . . . . . . . . . . 6-5

6-3 Tritium Activities in Well UE-19c WW from the Long-Term Hydrological Monitoring Program $\ldots \ldots \ldots \ldots \ldots \ldots \ldots \ldots \ldots \ldots \ldots \ldots \ldots \ldots \ldots \ldots$

6-4 Radionuclides in Groundwater at CHESHIRE (Well U-20n PS\#1 DDH) . . . . . . . . . . . . 6-7 


\section{List of Tables (Continued)}

Number

Title

Page

6-5 Radionuclides in Groundwater at CHESHIRE

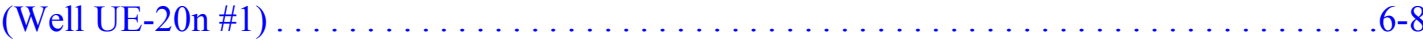

6-6 Filtration Results for Cavity Groundwater at CHESHIRE (Well U-20n PS\#1 DDH) . . . . . . .6-9

6-7 Filtration Results for Formation Groundwater at CHESHIRE (Well U-20n PS\#1 DDH) . . . .6-10

6-8 Radionuclides in Unfiltered Groundwater at Well ER-20-5 \#1 . . . . . . . . . . . . . . . . . . . 6-11

6-9 Radionuclides in Unfiltered Groundwater at Well ER-20-5 \#3 . . . . . . . . . . . . . . . .6-11

6-10 Filtration Results for Groundwater from Well ER-20-5 \#1 . . . . . . . . . . . . 6-12

6-11 Radionuclides in Groundwater at ER-20-5 Well Cluster . . . . . . . . . . . . . . . . . . . . .6-13

6-12 Radionuclides in Groundwater from Well ER-20-6 \#1 . . . . . . . . . . . . . . . . . . . . . .6-15

6-13 Radionuclides in Groundwater from Well ER-20-6 \#2 . . . . . . . . . . . . . . . . . . . . .6-15

6-14 Radionuclides in Groundwater at ER-20-6 Well Cluster

NNSA/NSO Environmental Restoration Program Sampling . . . . . . . . . . . . . .6-16

6-15 Average Annual Groundwater Activity Data for Well U-20 WW

from NTS Environmental Monitoring Program . . . . . . . . . . . . . . . . . . 6-17

6-16 Tritium Activities in Well U-20 WW from the Long-Term Hydrological

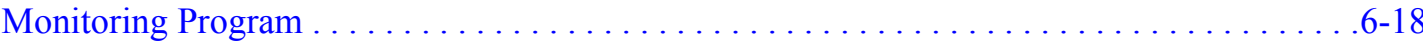

6-17 Tritium Activities in Well PM-1 Water . . . . . . . . . . . . . . . . . . . . . . .6-18

6-18 Radionuclides in Groundwater at Well PM-2. . . . . . . . . . . . . . . . . . . . . . . . .6-19

6-19 Tritium Activities in Oasis Valley Water from the

Long-Term Hydrological Monitoring Program. . . . . . . . . . . . . . . . . . . . . . . .6-21

6-20 Tritium Activity of Oasis Valley Water Samples . . . . . . . . . . . . . . . . . . 6-22

6-21 Results of Analysis for ER-EC-8 Water Samples:

Radiological Indicator Parameters . . . . . . . . . . . . . . . . . . . . . . . . 6-23

6-22 Results of Plutonium Analyses for Well ER-EC-8 Discrete Bailer Samples . . . . . . . . . . . . 6-24

7-1 Source Model Assumptions or Simplifications and Associated Limitations . . . . . . . . . . . . . . . 7-2

A.1-1 Hydrostratigraphic Units of the Pahute Mesa-Oasis Valley Hydrostratigraphic Framework Model . . . . . . . . . . . . . . . . . . . . . . . . . . . . . . . . . . . A-2

A.1-2 Hydrogeologic Units of the UGTA Regional Model in the PM-OV Model Area . . . . . . . . . A-8

A.1-3 Additional and Modified Hydrogeologic Units of the PM-OV Model $\ldots \ldots \ldots \ldots \ldots \ldots$ A-8 


\section{List of Acronyms and Abbreviations}

$\mathrm{Al}$

Am

$\mathrm{Ar}$

$\mathrm{Ba}$

bgs

$\mathrm{BN}$

C

CAI

CAS

CAU

$\mathrm{Ce}$

$\mathrm{Cl}$

Co

Cs

DOE

DRI

$\mathrm{Eu}$

EV

FEHM

FFACO

$\mathrm{ft}$

$\mathrm{g}$

$\mathrm{g} / \mathrm{cm}^{3}$

Gd

GDPM

gm

$\mathrm{H}$

HRMP

HST

HSU

I

IAEA
Aluminum

Americium

Argon

Becquerel

Below ground surface

Bechtel Nevada

Carbon

Corrective Action Investigation

Corrective Action Site

Corrective Action Unit

Cerium

Chlorine

Cobalt

Cesium

U.S. Department of Energy

Desert Research Institute

Europium

Exchange volume

Finite-element heat mass transfer code

Federal Facility Agreement and Consent Order

Foot (feet)

Gram

Grams per cubic centimeter

Gadolinium

Generalized Dual-Porosity Model

Gram

Tritium

Hydrologic Resources Management Plan

Hydrologic source term

Hydrostratigraphic Unit

Iodine

International Atomic Energy Agency 


\begin{tabular}{|c|c|}
\hline $\mathrm{K}$ & Hydraulic Conductivity \\
\hline $\mathrm{K}_{\mathrm{d}}$ & Distribution coefficient \\
\hline kcal & Kilo calorie \\
\hline $\mathrm{Kr}$ & Krypton \\
\hline $\mathrm{kt}$ & Kiloton \\
\hline LaGriT & Los Alamos Grid Toolbox \\
\hline LANL & Los Alamos National Laboratory \\
\hline LLNL & Lawrence Livermore National Laboratory \\
\hline LTHMP & Long-Term Hydrologic Monitoring Program \\
\hline $\mathrm{m}$ & Meter \\
\hline $\mathrm{m}^{2}$ & Square meters \\
\hline $\mathrm{m}^{3}$ & Cubic meters \\
\hline $\mathrm{m}^{3} / \mathrm{d}$ & Cubic meters per day \\
\hline $\mathrm{m}^{3} / \mathrm{kg}$ & Cubic meters per kilogram \\
\hline $\mathrm{m} / \mathrm{d}$ & Meters per day \\
\hline MDA & Minimum detectable activity \\
\hline MG & Melt glass \\
\hline $\mathrm{mg} / \mathrm{L}$ & Milligrams per liter \\
\hline $\mathrm{mL} / \mathrm{g}$ & Milliliters per gram \\
\hline $\mathrm{Mn}$ & Manganese \\
\hline Mt & Megaton \\
\hline $\mathrm{Na}$ & Sodium \\
\hline NDEP & Nevada Division of Environmental Protection \\
\hline NNSA/NSO & U.S. Department of Energy, National Nuclear Security Administration Nevada Site Office \\
\hline NTS & Nevada Test Site \\
\hline NUFT & Nonisothermal Unsaturated-Saturated Flow and Transport Model \\
\hline $\mathrm{O}$ & Oxygen \\
\hline $\mathrm{pCi} / \mathrm{L}$ & Picocuries per liter \\
\hline $\mathrm{Pd}$ & Palladium \\
\hline pdf & Probability density function \\
\hline PEST & Parameter estimation \\
\hline pfd & Probability frequency distribution \\
\hline Plfa & Paintbrush Lava-Flow Aquifer \\
\hline
\end{tabular}




\begin{tabular}{|c|c|}
\hline pmc & Percent modern carbon \\
\hline PM-OV & Pahute Mesa-Oasis Valley \\
\hline $\mathrm{Pu}$ & Plutonium \\
\hline $\mathrm{R}$ & Retardation Coefficients \\
\hline $\mathrm{Rb}$ & Rubidium \\
\hline RST & Radiological Source Term \\
\hline $\mathrm{Ru}$ & Ruthenium \\
\hline $\mathrm{Sb}$ & Antimony \\
\hline SEM & Scanning electron microscope \\
\hline Shaw & Shaw Environmental, Inc. \\
\hline $\mathrm{Sm}$ & Samarium \\
\hline Sn & Tin \\
\hline SNJV & Stoller-Navarro Joint Venture \\
\hline $\mathrm{Sr}$ & Strontium \\
\hline SSM & Simplified source model \\
\hline $\mathrm{Tc}$ & Technetium \\
\hline THC & Thermal-hydrologic-chemical \\
\hline TNT & Trinitrotoluene \\
\hline TWG & Technical Working Group \\
\hline $\mathrm{U}$ & Uranium \\
\hline UGTA & Underground Test Area \\
\hline USGS & U.S. Geological Survey \\
\hline XRD & $\mathrm{X}$-ray diffraction \\
\hline $1-\mathrm{D}$ & One-dimensional \\
\hline $3-\mathrm{D}$ & Three-dimensional \\
\hline$\mu \mathrm{m}$ & Micrometer \\
\hline$\delta$ & Delta \\
\hline
\end{tabular}




\subsection{Introduction}

This report documents the evaluation of the information and data available on the unclassified source term and radionuclide contamination for Central and Western Pahute Mesa: Corrective Action Units (CAUs) 101 and 102. The methodology to estimate hydrologic source terms (HSTs) for these CAUs is also documented. The HST of an underground nuclear test is the portion of the total inventory of radionuclides that is released into the groundwater over time following the explosion of an underground nuclear test. The total inventory of radionuclides is known as the radiologic source term (RST). The evaluation was conducted in support of the development of a CAU contaminant transport model for these two CAUs. Central and Western Pahute Mesa constitute one of several areas of the Nevada Test Site (NTS) used for underground nuclear testing (Figure 1-1). These nuclear tests resulted in groundwater contamination in the vicinity of the underground test areas. As a result, the U.S. Department of Energy (DOE), National Nuclear Security Administration Nevada Site Office (NNSA/NSO) is currently conducting a corrective action investigation of the Pahute Mesa underground test areas. A brief summary of the site and project background are provided, followed by a presentation of the purpose and scope of the work described in this document. A brief description of this document's contents is provided at the end of this section.

\subsection{Site Background}

Between 1951 and 1992 the DOE and the U.S. Department of Defense (DoD) conducted underground nuclear testing at the NTS. Pahute Mesa was used as an underground nuclear testing area for 27 years. Nuclear testing on Pahute Mesa began with Operation Whetstone in 1965 and ended with Operation Julin in 1992 (DOE/NV, 2000).

Nuclear tests conducted at Pahute Mesa that are of interest to the Underground Test Area (UGTA) Project were detonated in deep vertical shafts, drilled into volcanic rock near or below the water table. Of the total of 85 nuclear tests conducted on Pahute Mesa, three were cratering tests and 82 were conducted underground. The three cratering tests are not part of the UGTA Project. Sixty-four of the 82 underground tests were detonated on Central Pahute Mesa (CAU 101), and eighteen tests were detonated in Western Pahute Mesa (CAU 102) (DOE/NV, 1999). Media contaminated by the underground nuclear tests of Pahute Mesa are portions of the unsaturated and saturated zones. Transport in groundwater is the primary mechanism for migration of the subsurface contamination away from the Pahute Mesa underground nuclear test areas. 


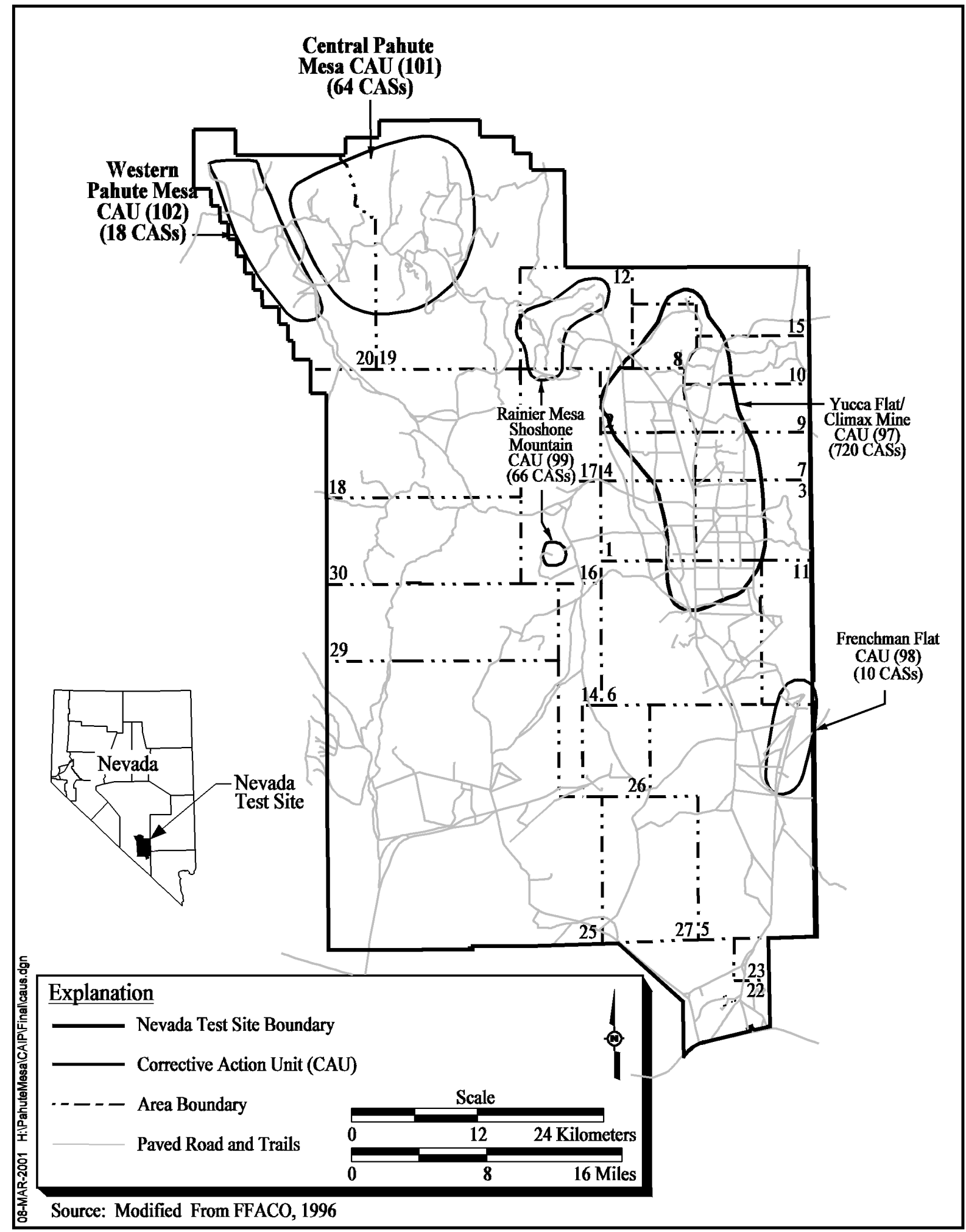

Figure 1-1

Location of the Pahute Mesa Corrective Action Units 


\subsection{Project Background}

To ensure protection of the public and the environment, NNSA/NSO established a long-term program to monitor groundwater for the presence of radionuclides, and the UGTA project to investigate and remediate the underground test areas. The UGTA Project is a component of the Nevada Environmental Restoration Program (NV ERP).

UGTA activities are conducted under the direction of the NNSA/NSO UGTA Project Manager. A Technical Working Group (TWG) was formed to assist the NNSA/NSO UGTA Project Manager with technical management issues. The TWG consists of representatives from the participating organizations which include Bechtel Nevada (BN), Desert Research Institute (DRI), Stoller-Navarro Joint Venture (SNJV), Lawrence Livermore National Laboratory (LLNL), Los Alamos National Laboratory (LANL), and the U.S. Geological Survey (USGS). The TWG serves as a technical advisory group to the NNSA/NSO UGTA Project Manager. Tasks assigned to the TWG committee include providing technical recommendations to NNSA/NSO, providing expert technical support in specific UGTA tasks via subcommittees, and serving as internal peer reviewers of UGTA products.

Since 1996, the Nevada Division of Environmental Protection (NDEP) regulates NNSA/NSO's corrective actions through the Federal Facility Agreement and Consent Order (FFACO) (1996). Appendix VI of this agreement, "The Corrective Action Strategy," was revised in 2000 and describes the processes that will be used to complete corrective actions, including those in the UGTA Project. The individual locations covered by the agreement are known as Corrective Action Sites (CASs), and they are grouped into Corrective Action Units. The UGTA CAUs are Frenchman Flat, Central Pahute Mesa, Western Pahute Mesa, Yucca Flat/Climax Mine, and Rainier Mesa/Shoshone Mountain (Figure 1-1). Central Pahute Mesa (CAU 101) and Western Pahute Mesa (CAU 102) are addressed together due to their adjacent locations, common groundwater regime, and similarities in testing practices, geology, and hydrology.

\subsection{Task Purpose and Scope}

This section describes the purpose and scope of the unclassified hydrologic source term and radionuclide data analysis task documented in this report.

\subsubsection{Task Purpose}

The purpose of this task is to analyze available information on the unclassified hydrologic source term and data on radionuclides relevant to the Pahute Mesa CAUs. The results of this analysis will support the development of the CAU transport model. 
Specific task objectives are as follows:

- Compile and review available information and data relating to the unclassified source term and radionuclide contamination.

- Develop a method for abstracting the hydrologic source term for incorporation into the CAU model.

- Evaluate the available radionuclide data to estimate the current extent of radionuclide contamination in support of the CAU contaminant transport model.

\subsubsection{Scope of Work}

The scope of this task includes the analysis of information and data relevant to the radionuclides present in the groundwater system of the Pahute Mesa CAUs.

Information relating to the unclassified radiologic and hydrologic source terms is of primary interest. Data of interest include observed radionuclide activities at various wells and springs located on Pahute Mesa and vicinity. Other information of interest includes various studies relating to the migration of radionuclides in groundwater away from the nuclear test locations. Descriptions of the available information and data are provided in Section 3.0 and Section 6.0.

Data evaluation includes: (1) literature searches, (2) information and data compilation, and (3) data analysis activities. Data analysis includes estimating uncertainty associated with the available information.

The area of investigation, as described in the CAIP (Figure 1-2), was selected to encompass the Pahute Mesa CAUs and areas located downgradient that may be impacted by these CAUs. The investigation area includes the Pahute Mesa-Oasis Valley (PM-OV) area and a portion of the Amargosa Desert located downgradient of the Pahute Mesa CAUs. This area of over 2,700 square kilometers encompasses the northwestern portion of the NTS and adjacent lands to the west managed by the U.S. Air Force and the Bureau of Land Management. The PM-OV area includes Timber Mountain, Black Mountain, Oasis Valley, Beatty Wash, and the northern parts of Yucca Mountain and Fortymile Canyon. The groundwater flow model area is virtually the same as the PM-OV area (Figure 1-2).

\subsection{Corrective Action Investigation Documentation}

The Pahute Mesa Corrective Action Investigation (CAI) activities will be documented in various reports describing the results of the characterization 


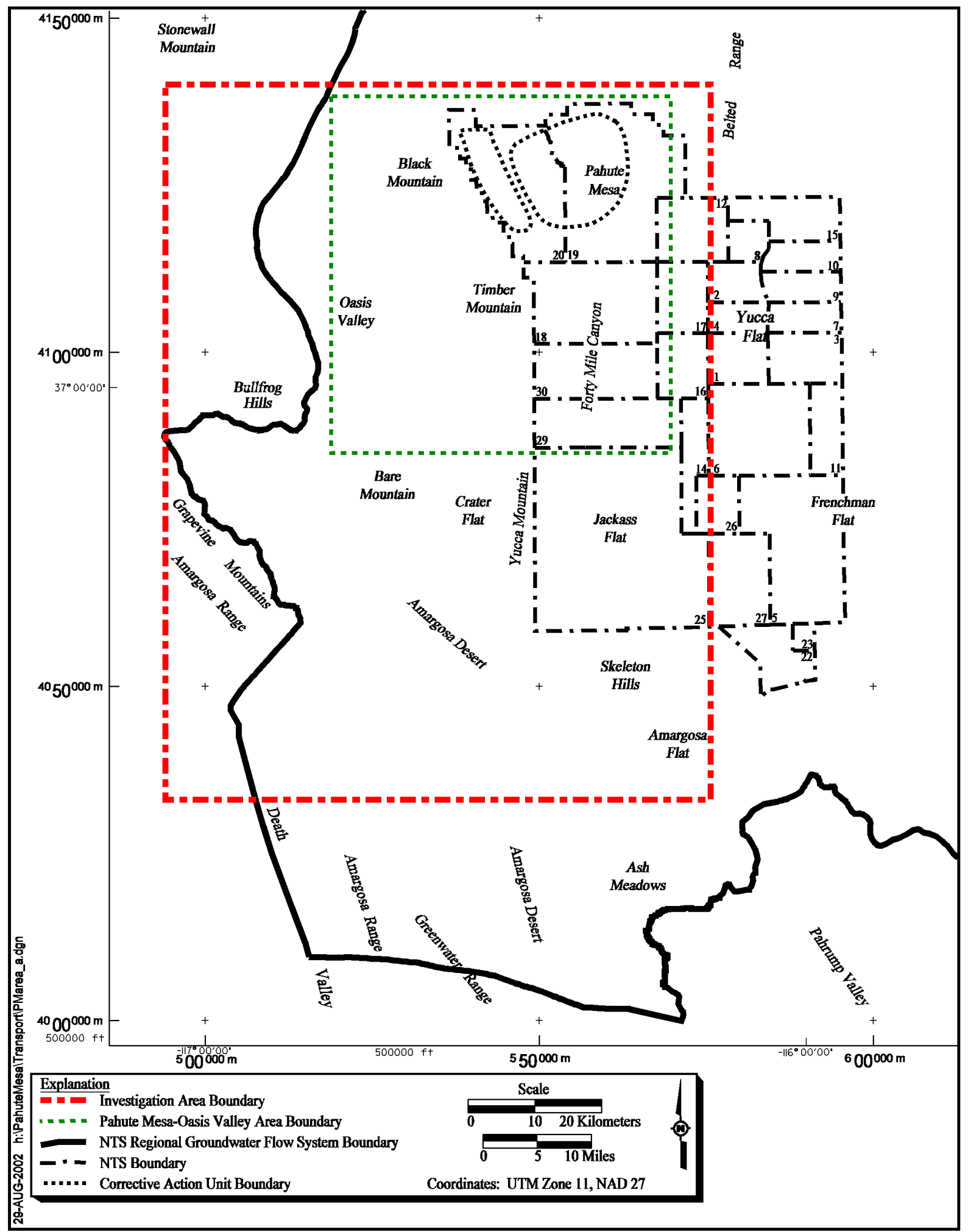

Figure 1-2

Investigation and PM-OV Areas for the Pahute Mesa Corrective Action Units 
activities and a series of reports describing the CAU model, associated data, and results. The CAU model documentation consists of the following reports:

- A report describing the assessment of geologic data and the resulting hydrostratigraphic model titled A Hydrostratigraphic Model and Alternatives for the Groundwater Flow and Contaminant Transport Model of Corrective Action Units 101 and 102: Central and Western Pahute Mesa, Nye County, Nevada (BN, 2002).

- A report describing the analysis of hydrologic data in support of the CAU groundwater flow model.

- A report describing the analysis of contaminant transport parameter data titled Contaminant Transport Parameters for the Groundwater Flow and Contaminant Transport Model of Corrective Action Units 101 and 102: Central and Western Pahute Mesa, Nye County, Nevada (Rehfeldt et al., 2003).

- This report which describes the analysis of the data available on the unclassified hydrologic source term and radionuclide concentrations for the PM-OV area.

- A report describing the groundwater flow model developed for the PM-OV area.

- A report describing the radionuclide transport model developed for the PM-OV area.

- A report summarizing all data analysis and modeling activities. This document will include a summary of the information presented in the six documents listed above.

\subsection{Document Organization}

This document consists of eight sections and four appendices. Summaries of the section contents follow:

- Section 1.0 provides a description of the project background, the purpose and scope of this data analysis task, and this summary of the document.

- Section 2.0 provides a summary description of the modeling approach proposed for the Pahute Mesa CAUs.

- Section 3.0 provides summary descriptions of the information available on radionuclide contamination sources and extent for the Pahute Mesa CAUs.

- Section 4.0 presents the approach used to simplify the hydrologic source term process model. 
- Section 5.0 describes the process that will be used to quantify the hydrologic source term prior to input in the CAU models.

- Section 6.0 presents the radionuclide data available to date, along with a discussion on the nature and extent of radionuclide contamination originating from the Pahute Mesa CAUs.

- Section 7.0 provides a summary and describes the limitations associated with the information presented in this document.

- Section 8.0 provides a list of references used in this document.

- Appendix A contains a description of the Pahute Mesa hydrostratigraphic unit model layers.

- Appendix B contains a description of the GoldSim ${ }^{\circledR}$ software package used to develop the simplified source term model.

- Appendix C contains a description of the GeoChem database which includes radionuclide data for the Pahute Mesa CAUs.

- Appendix D provides comparisons of mass fluxes from the simplified source term model and the CHESHIRE process model 


\subsection{Corrective Action Unit Modeling Approach}

This section presents an overview of the CAU modeling approach and descriptions of the contaminant transport modeling approach and data requirements. This information provides a basis for understanding the importance of the hydrologic source term, the contamination data and various other groundwater flow and transport parameters, and their use in the CAU models.

\subsection{Overview of CAU Modeling Approach}

Underground nuclear testing at the NTS included a total of 908 detonations in shafts and tunnels with approximately one-third of these tests conducted near or below the water table (DOE/NV, 1997b). Groundwater flow through these sources occurs through diverse and structurally complex rocks (Laczniak et al., 1996). Given the complexity of the system, contamination sources, and processes controlling transport, computer models will be required to meet the objectives of the FFACO strategy. The modeling approach used to develop an integrated three-dimensional (3-D) model for flow and transport begins with characterization of the system, development of conceptual models based on assumptions of system processes, and representation of these processes mathematically. Mathematical models are then implemented on a computer to represent the system.

The CAU flow and transport models will consist of an integrated set of models. Some of these models focus on a small-scale (relative to the CAU) process such as radionuclide release from source regions and others simplifying CAU-scale processes (e.g., reactive transport in fractures to an abstraction for system sensitivity analysis). Combined, the models (referred to as component models) constitute the CAU predictive model.

The integrating numerical model will be a 3-D finite-element flow and transport simulator that captures the complex geologic structure including units of variable thickness, faults, and offsets, as well as complex transport processes associated with reactive solutes and fractured rock. The CAU groundwater flow model component requires two other component models: the NTS regional groundwater flow model and the recharge model. The CAU contaminant transport model component requires the hydrologic source term model.

To ensure fidelity of the CAU model to the physical system, a 10-step protocol will be utilized. These ten steps are: (1) establishment of model purpose, (2) development of conceptual model, (3) selection of a computer code and verification of the code, (4) model design, (5) model calibration, (6) sensitivity 
and uncertainty analyses, (7) model verification, (8) predictive simulations, (9) presentation of model results, and (10) postaudit.

\subsubsection{Selected Code}

The finite-element heat mass transfer (FEHM) code (Zyvoloski et al., 1997 a and b), developed by LANL, was chosen for the Pahute Mesa CAU-scale flow, and transport model (DOE/NV, 1999). FEHM simulates 3-D, time-dependent, multiphase, nonisothermal flow, and multicomponent, reactive groundwater transport through porous and fractured media. FEHM's finite-element formulation provides an accurate representation of complex 3-D geologic media and structures and their effects on subsurface flow and transport. Specific capabilities include:

- 3-D

- Flow of air, water, and heat

- Multiple chemically reactive and sorbing tracers

- Colloid transport

- Finite element/finite volume formulation

- Coupled stress module

- Saturated and unsaturated media

- Preconditioned conjugate gradient solution of coupled nonlinear equations

- Porous media equivalent model

- Double porosity and double porosity/double-permeability capabilities

- Complex geometries with unstructured grids

- Two different reactive, dual-porosity, particle-tracking modules

- Coupled to parameter estimation (PEST) software

- Linked with Los Alamos Grid Toolbox (LaGriT) grid generation software

- Supported on SUN, SGI, ALPHA, and Intel (windows)

Documentation includes a description of the mathematical models and numerical methods used by FEHM (Zyvoloski et al., 1997a), the user's manual (Zyvoloski et al., 1997b), documentation of the functional and performance requirements for FEHM, description of the FEHM software, and verification and validation reports (Dash et al., 1997; Dash, 2000 and 2001). Further, the software is maintained in configuration management at LANL. With each new release, the software is subjected to a rigorous verification test to ensure accuracy and functionality of all capabilities.

Assumptions for the flow and energy transport models in FEHM include fluid flow governed by Darcy's law, thermal equilibrium between fluid and rock, immovable rock phase, and negligible viscous heating. Specific assumptions are discussed further by Zyvoloski et al. (1997a).

Inputs to the flow model include the finite-element grid, initial conditions, lateral boundary conditions, recharge, and material properties for HSUs and faults. For application to isothermal groundwater flow, the calibrated FEHM model produces values of hydraulic head or pressure for each node in the grid. 
PEST, a software package developed by Watermark Computing (2000), provides a nonlinear parameter estimation routine that can be used to automatically calibrate a flow model. PEST can be used with any existing modeling computer code for model calibration without making any changes to that code. However, FEHM was recently modified to efficiently provide data needed by PEST in each iteration with no additional post-processing. LaGriT (George, 1997) is an auxiliary code to the FEHM code (Zyvoloski et al., 1997b), developed by LANL to generate finite-element meshes for FEHM models.

All three codes, FEHM (Zyvoloski et al., 1997b), PEST (Watermark Computing, 2000), and LaGriT (George, 1997) have been used in the Yucca Mountain Project modeling activities. Their usage in the development of the YMP saturated zone flow model is documented in a report titled: Calibration of the Site-Scale Saturated Zone Flow Model (CRWMS M\&O, 2000). All YMP models are developed under their quality assurance program (DOE, 2000).

\subsubsection{Data Requirements}

Data requirements for the CAU model fall into the three categories listed below.

\section{Groundwater Flow}

Data types required for the groundwater flow model include permeability (or hydraulic conductivity), storage parameters, precipitation recharge, lateral boundary fluxes, hydraulic heads, and groundwater chemistry. These data types are the subject of the hydrologic data report for Pahute Mesa.

\section{Contamination Sources and Extent}

Contaminants are currently located in the 82 test locations and downgradient areas in Western and Central Pahute Mesa. The information on the unclassified hydrologic source term and the radionuclide data for Central and Western Pahute Mesa are the subject of this report and detailed in Sections 3.0 through 6.0.

\section{Transport Parameters}

Major transport data types of interest include effective porosity, dispersivity, matrix porosity, matrix diffusion, sorption coefficients, and colloid-facilitated transport parameters. Note that for the purpose of modeling, effective porosity and matrix porosity are considered to be transport parameters rather than hydrologic parameters as they are required input variables in the contaminant transport model. Details for these parameters are the subject of Contaminant Transport Parameters for Groundwater Flow and Contaminant Transport Model of Corrective Action Units 101 and 102: Central and Western Pahute Mesa, Nye County, Nevada (Rehfeldt et al., 2003). 


\subsection{Transport Modeling Approach and Data Requirements}

This section describes the approach used for modeling the transport of contaminants in the groundwater flow system of the PM-OV area. The associated data requirements are also described.

\subsubsection{Modeling Approach}

The CAU transport model will be built upon the groundwater flow model using the contaminant transport capabilities of the FEHM code (Zyvoloski et al., 1997b). The CAU transport model will then be used to simulate the transport of radionuclides in the aquifer system of Pahute Mesa and vicinity. The objectives and modeling process are briefly described.

\subsubsection{Objectives}

Using the CAU transport model, mass fluxes and concentrations of radionuclides will be calculated for specified points located downgradient from the underground nuclear tests of Pahute Mesa. Simulated concentrations will then be used to estimate the location of the contaminant boundary as defined in the FFACO (1996).

\subsubsection{Modeling Process}

The contaminant transport modeling process will consist of the following steps:

- Identifying radionuclide transport processes at work

- Designing of a simulation strategy

- Conducting transport model simulations

- Conducting sensitivity analyses

- Conducting uncertainty analyses

\section{Transport Processes}

The Pahute Mesa CAU transport model will need to account for the following processes:

- Advective and dispersive solute transport

- Diffusion of solutes from fractures into matrix material

- Retardation of solutes on fracture minerals

- Retardation of solutes on matrix minerals

- Enhanced mobility of solutes due to colloids

- Retardation of colloids via filtration and attachment to fracture walls 


\section{Simulation Strategy}

Saturated zone transport can be simulated with continuity equations on a finite-element grid, with particle-tracking techniques, or with continuity equations along one-dimensional (1-D) grids, mapped to coincide with flow paths in a 3-D flow field.

Solving the continuity equations in 3-D or along 1-D pathways allows for the greatest flexibility in representing reactive processes. Fully coupled kinetic and equilibrium reactions describing multicomponent, aqueous-aqueous, and aqueous-solid reactions can be accommodated with a dual-porosity methodology suitable for capturing fracture-matrix interactions. However, such simulations are computationally demanding and may not be appropriate for extensive CAU-scale simulations, particularly when uncertainty is addressed with Monte Carlo-type simulations. In addition, as further shown in Section 4.0, equilibrium assumptions can still reasonably capture reactive transport processes. Although slightly more limited in the reactions that can be addressed, the 3-D streamline particle-tracking transport algorithm is significantly more efficient than finite-element solutions of the continuity equations, and is planned for use in transport uncertainty calculations.

The particle-tracking model is a full, dual-porosity method for simulating transport. It can be used to simulate dual-porosity transport with: (a) advection in fractures, (b) diffusion into the matrix, (c) solute retardation on fracture minerals, and (d) solute reaction with matrix minerals. Fracture properties such as aperture, spacing, and reactivity can vary spatially as can matrix reactivity.

The limitation of the particle-tracking solver compared to the continuity equation solver is that solute-solute reactions cannot be simulated with the particle-tracking model. This means that an abstraction of complex processes such as solute-colloid reactions must be developed prior to the simulations. Such an abstraction may be developed with a limited number of simulations of the complete set of continuity equations. It involves identifying the transport parameters associated with a new species, plutonium-colloid. The new species can then be simulated independently via particle tracking. Another limitation of the particle-tracking model is that it is incapable of considering kinetic sorption processes and filtration of colloids. Thus, one approach is to use an abstraction of the fully-coupled process model to justify equilibrium factors for such processes as colloid attachment and detachment to fracture walls.

\section{Radionuclide Transport Simulations}

Deterministic transport simulations will be conducted to predict the movement of contaminants in the groundwater.

The finite-element mesh will be refined around the test. A limited number of simulations may be conducted using the finite-element, dual-porosity, reactive transport module to condition and validate parameters that will be used in the particle-tracking simulations. Predictive simulations will be made using the dual-porosity, streamline, particle-tracking module of FEHM. 


\section{Sensitivity Analyses}

Sensitivity analyses will be performed after the deterministic part of the contaminant transport model is completed. The objective of the sensitivity analyses is to assess the response of the predicted concentration values as a result of changes in input parameter values.

The results of the sensitivity analyses will be used to guide potential additional data collection efforts or model validation data to ensure that meaningful data are collected. Results of the sensitivity analyses may also help define monitoring locations and the type of data to be collected for the monitoring network design.

For the transport calculations where predictions extend well into the future, the sensitivity provides different information. The most sensitive parameters for contaminant transport do not have reduced uncertainty because it is not possible to calibrate to future events. The most sensitive transport parameters identify the parameters of most concern because the range of uncertainty must be constrained by information external to the transport model.

\section{Uncertainty Analyses}

Uncertainty analyses will follow the sensitivity analyses. The purpose of these analyses is to quantify the level of uncertainty associated with the CAU-modeling results. The uncertainty of the predicted contaminant concentrations and the location of the contaminant boundary is caused by the uncertainties in the data used to build the CAU model. Model result uncertainties caused by uncertainties in the HSU model, hydrologic source term, transport parameter values, or boundary conditions will be evaluated.

The approach to quantifying the uncertainty in the hydrologic source term and transport parameter values is via the Monte Carlo approach. One Monte Carlo realization will consist of a set of input parameters sampled from their respective probability distributions, and a simulation using FEHM. The probability distribution of model response (contaminant concentrations) is determined from the simulations and provides an assessment of uncertainty in the model predictions. The Monte Carlo method can provide a quantitative measure of the uncertainty in the location of the contaminant boundary.

Assessment of sources of uncertainty that cannot be described via a probability distribution will be included in a different manner. For example, the alternative interpretations of the HSU model will actually be evaluated using separate models. In this case, the simulation of contaminant concentrations for each alternative provides a quantitative change in a measure (e.g., the contaminant boundary). Other sources of uncertainty that cannot be described by a probability function will be treated in a similar manner.

\subsubsection{Data Requirements}

A wide variety of data types are required to simulate radionuclide transport in the groundwater system. These data are summarized below. 


\section{Hydrologic Source Term}

The hydrologic source term is unknown but may be estimated using the radiologic source term. The individual radiologic source term is classified for all underground nuclear tests. Two estimates of the hydrologic source term, unclassified and classified, will be made for Pahute Mesa. The unclassified hydrologic source term will be derived from the unclassified version of the radiologic source term for Pahute Mesa. The unclassified hydrologic source term will be extrapolated to all underground tests on Pahute Mesa. The classified version of the hydrologic source term will be based on classified information from individual tests and will be used to calculate the final location of the contaminant boundary.

The source of radionuclides for the CAU transport model will be abstracted release functions from the underground nuclear tests of Pahute Mesa. These will be in the form of mass flux versus time at the working point of the tests and the intersection of aquifers with the cavity/chimney systems associated with the tests. For more details on the unclassified source term, see Sections 4.0 and 5.0 of this document. The classified version of the hydrologic source term and associated radionuclide transport simulations will be documented in a classified report.

\section{Transport Parameters}

Parameters needed to simulate the radionuclide transport processes at work in the Pahute Mesa flow system include effective porosity, dispersivity, radioactive decay constants, distribution coefficients, matrix diffusion coefficients, matrix porosity, description of the fracture geometry, and colloid-facilitated transport parameters. The various transport parameters are described in a report titled: Contaminant Transport Parameters for the Groundwater Flow and Contaminant Transport Model of Corrective Action Units 101 and 102: Central and Western Pahute Mesa, Nye County, Nevada (Rehfeldt et al., 2003).

\section{Observed Radionuclide Data}

Measurements of radionuclide concentrations in groundwater samples may be useful in evaluating the CAU-model predictions. These data may be used to constrain or calibrate transport models; thus, providing further confidence in the simulations. Evidence of radionuclide migration away from test locations, such as was observed near the TYBO test, could be compared with simulated results of the CAU model. The direct measurement of radionuclide concentrations in cavity water samples is used to constrain and validate hydrologic source term model predictions. Additionally, time series of radionuclide concentrations from cavity samples may be of sufficient quality to compare with simulated concentration declines at the same locations. 


\section{Review of Available Information}

Modeling the release of radionuclides from the radiologic source term and their migration within the Pahute Mesa groundwater system requires an understanding of the sources of radionuclides, their migration, and the processes involved. Currently, available information on the sources of radionuclide contamination includes (1) underground nuclear test data, (2) the phenomenology of underground nuclear tests, (3) the unclassified radionuclide inventory, and (4) radionuclide distribution in the nuclear test cavities and vicinity. Radionuclide distribution resulting from migration in groundwater may be derived from observed radionuclide activities. To better understand and quantify the processes involved in the release and migration of radionuclides within the near-field, LLNL developed near-field process models for Frenchman Flat and Pahute Mesa. LLNL defines the near-field as the subsurface environment located within several cavity radii of the test, with modeling domains ranging from about $500 \mathrm{~m}$ to $800 \mathrm{~m}$. Specifically, these models include: (1) the CAMBRIC hydrologic source-term (HST) model, (2) the Frenchman Flat Simplified HST model, and (3) the CHESHIRE HST Model. The various factors contributing to the uncertainties associated with defining the hydrologic source-term have been evaluated by Smith et al. (1995). A local groundwater flow and transport model of the TYBO-BENHAM area is available to help understand the processes of importance at the intermediate scale. A description of this information is presented in this section.

\subsection{Underground Nuclear Test Data}

Nuclear testing on Pahute Mesa began with Operation Whetstone in 1965 and ended with Operation Julin in 1992 (DOE/NV, 2000). The nuclear tests of interest to the UGTA Project were detonated in deep shafts, drilled into volcanic rock above or below the water table. Tests that were conducted in the shallow subsurface of Pahute Mesa are not part of the UGTA Project. These tests are PALANQUIN, CABRIOLET, and SCHOONER and are currently being addressed under the Soils Project.

A total of 82 shaft nuclear tests were conducted on Pahute Mesa. Only shaft tests were detonated on Pahute Mesa. Shaft nuclear devices were exploded in drilled or mined vertical holes. Of the 82 tests, 64 were detonated on Central Pahute Mesa, (CAU 101), and 18 were detonated on Western Pahute Mesa (CAU 102). In the FFACO (1996), each of the 82 shaft nuclear tests corresponds to a corrective action site. These locations of the shaft nuclear tests are shown in Figure 3-1. 


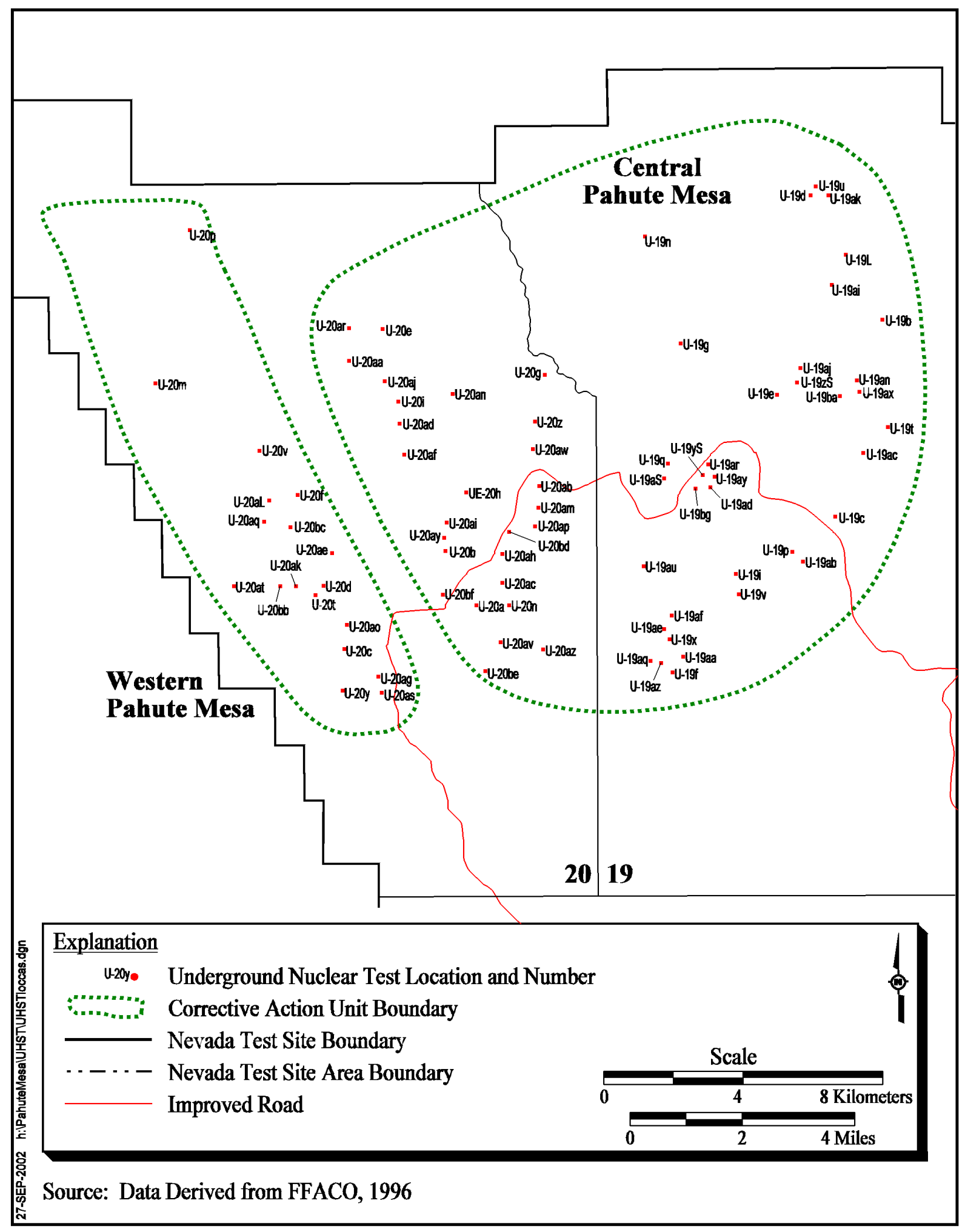

Figure 3-1

Location of Underground Nuclear Tests on Pahute Mesa 
Three tests (BOXCAR, BENHAM, and HANDLEY) resulted in the highest yield ranges in Pahute Mesa (Table 3-1). They exceeded the kiloton (kt) threshold and achieved megaton (Mt) status (DOE/NV, 2000). All 3 tests (Table 3-1), were detonated well below the water table. BENHAM, the deepest test of this group, was detonated 763 meters $(\mathrm{m})$ below the water table (Table 3-1).

Table 3-1

Largest Underground Nuclear Tests on Pahute Mesa

\begin{tabular}{|c|c|c|c|c|}
\hline $\begin{array}{c}\text { Test } \\
\text { Name }^{a}\end{array}$ & $\begin{array}{c}\text { Detonation } \\
\text { Date }^{\mathrm{a}}\end{array}$ & $\begin{array}{l}\text { Yield Range } \\
\qquad(\mathrm{Mt})^{\mathrm{a}}\end{array}$ & $\begin{array}{l}\text { Depth of } \\
\text { Burial }^{\text {b }} \\
\text { (m bgs) }\end{array}$ & $\begin{array}{c}\text { Depth-to-Water } \\
\text { (m bgs) }\end{array}$ \\
\hline BOXCAR & April 26,1968 & 1.3 & 1,166 & 595 \\
\hline BENHAM & December 19, 1968 & 1.15 & 1,402 & 639 \\
\hline HANDLEY & March 26, 1970 & More than 1 & 1,209 & 387 \\
\hline
\end{tabular}

aSource: DOE/NV, 2000

bSource: Pawloski, 2004

'Source: BN, 2002

$\mathrm{m}$ bgs $=$ Meters below ground surface

Table 3-2 and Table 3-3 identify each of the nuclear tests along with their individual features in CAU 101 and CAU 102, respectively. Each table lists the test name, emplacement hole name, CAS number, test coordinates, detonation date, yield range, calculated cavity radius (based on maximum announced yield), land surface elevation, water level elevation, and working point information. Most of the information was obtained from United States Nuclear Tests--July 1945 through September 1992 (DOE/NV, 2000). Note that the actual measured cavity radii are classified. Water levels at the test locations were derived from a water level map published in the HSU model report (BN, 2002). Based on the data presented in Table 3-2 and Table 3-3, 34 tests were conducted below the water table, and 48 tests above the water table (of which 45 were conducted within $100 \mathrm{~m}$ of the water table).

The term "yield range" refers to the total effective energy released in a nuclear explosion and is usually expressed in terms of equivalent tonnage of trinitrotoluene (TNT) required to produce the same energy release in an explosion. A kt yield range represents the energy of a nuclear explosion that is equivalent to the explosive power of one thousand tons of TNT, and a Mt is equivalent to one million tons of TNT (DOE/NV, 2000).

\subsection{Phenomenology and Phenomenological Models}

Phenomenology describes the effects of a nuclear explosion on the host media as a function of time. Phenomenological models describe the modifications to the media resulting from the explosion. An overview of the phenomenology of 
Table 3-2

Underground Shaft Nuclear Tests Conducted in Central Pahute Mesa (CAU 101)

(Page 1 of 3 )

\begin{tabular}{|c|c|c|c|c|c|c|c|c|c|c|c|c|}
\hline \multirow[b]{2}{*}{ Test Name ${ }^{a}$} & \multirow{2}{*}{ Hole Name $^{a}$} & \multirow{2}{*}{ CAS No. ${ }^{b}$} & \multirow{2}{*}{$\begin{array}{l}\text { Easting }^{c} \\
\quad(\mathrm{~m})\end{array}$} & \multirow{2}{*}{$\begin{array}{l}\text { Northing }^{c} \\
\quad(\mathrm{~m})\end{array}$} & \multirow{2}{*}{$\begin{array}{l}\text { Test } \\
\text { Date }^{\mathrm{a}}\end{array}$} & \multirow{2}{*}{$\begin{array}{c}\text { Yield } \\
\text { Range }^{\mathrm{a}} \\
\text { (kt) }\end{array}$} & \multirow{2}{*}{$\begin{array}{l}\text { Calculated } \\
\text { Cavity } \\
\text { Radius }^{\mathrm{d}} \\
(\mathrm{m})\end{array}$} & \multirow{2}{*}{$\begin{array}{c}\text { Land } \\
\text { Surface } \\
\text { Elevation }^{\mathrm{c}} \\
(\mathrm{m} \text { amsl) }\end{array}$} & \multirow{2}{*}{$\begin{array}{l}\text { Water Level } \\
\text { Elevation } \\
(\mathrm{m} \text { amsl })\end{array}$} & \multicolumn{3}{|c|}{ Working Point } \\
\hline & & & & & & & & & & $\begin{array}{l}\text { Elevation } \\
(\mathrm{m} \text { amsl })\end{array}$ & $\mathrm{HGU}^{\mathrm{g}}$ & HSU $^{\mathrm{h}}$ \\
\hline ALAMO & U19au & 19-57-014 & 555278.488 & 44122855.75 & $07 / 07 / 1988$ & $<150$ & 61 & 1,992 & 1,366 & 1,369 & LFA & $\overline{\mathrm{CHVCM}}$ \\
\hline ALMENDRO & U19v & $19-57-033$ & 558003.07 & 4122055.1 & 06/06/1973 & $200-1,000$ & 101 & 2,096 & 1,389 & 1,029 & TCU & BFCU \\
\hline AMARILLO & U19ay & $19-57-016$ & 557311.377 & 4125422.57 & $06 / 27 / 1989$ & $20-150$ & 61 & 2,046 & 1,398 & 1,406 & LFA & PLFA \\
\hline BACKBEACH & U19x & $19-57-034$ & 556020.555 & 4120757.93 & $04 / 11 / 1978$ & $20-150$ & 60 & 2,067 & 1,361 & 1,395 & LFA & PLFA \\
\hline BARNWELL & U20az & $20-57-026$ & 552392.361 & 4120468.47 & $12 / 08 / 1989$ & $20-150$ & 62 & 2,003 & 1,340 & 1,403 & TCU & $\mathrm{CHZCM}$ \\
\hline BEXAR & U19ba & $19-57-019$ & 560899.236 & 4127735.55 & 04/04/1991 & $20-150$ & 61 & 2,145 & 1,454 & 1,515 & LFA & $\mathrm{KA}$ \\
\hline BODIE & U20ap & $20-57-018$ & 552166.918 & 4124002.43 & $12 / 13 / 1986$ & $20-150$ & 61 & 2,018 & 1,359 & 1,383 & TCU & $\mathrm{CHVCM}$ \\
\hline BOXCAR & U20i & $20-57-039$ & 548242.936 & 4127580.93 & $04 / 26 / 1968$ & 1,300 & 108 & 1,942 & 1,356 & 776 & LFA & CFCM \\
\hline BULLION & U20bd & $20-57-030$ & 551420.292 & 4123847.44 & 06/13/1990 & $20-150$ & 60 & 1,977 & 1,356 & 1,303 & TCU & $\mathrm{CHZCM}$ \\
\hline CABRA & U20aj & $20-57-012$ & 547855.419 & 4128161.88 & 03/26/1983 & $20-150$ & 63 & 1,934 & 1,358 & 1,391 & LFA & $\mathrm{CHZCM}$ \\
\hline CAMEMBERT & U19q & $19-57-030$ & 555976.596 & 4125798.46 & 06/26/1975 & $200-1,000$ & 96 & 2,060 & 1,401 & 748 & $\mathrm{TCU}$ & BFCU \\
\hline CHANCELLOR & U19ad & $19-57-004$ & 557182.928 & 4125122.57 & 09/01/1983 & 143 & 60 & 2,040 & 1,396 & 1,416 & LFA & PLFA \\
\hline CHARTREUSE & U19d & $19-57-022$ & 560056.499 & 4133488.76 & 05/06/1966 & 73 & 47 & 2,091 & 1,450 & 1,424 & WTA & BRA \\
\hline CHESHIRE & U20n & $20-57-041$ & 551424.352 & 4121743.06 & $02 / 14 / 1976$ & $200-500$ & 78 & 1,974 & 1,344 & 807 & LFA & $\mathrm{CHZCM}$ \\
\hline COLBY & U20aa & $20-57-003$ & 546837.431 & 4128745.18 & 03/14/1976 & $500-1,000$ & 96 & 1,931 & 1,362 & 659 & TCU & CFCM \\
\hline COLWICK & U20ac & $20-57-005$ & 551226.464 & 4122384.41 & $04 / 26 / 1980$ & $20-150$ & 61 & 1,973 & 1,348 & 1,340 & LFA & $\mathrm{CHZCM}$ \\
\hline COMSTOCK & U20ay & $20-57-025$ & 549562.425 & 4123673.3 & 06/02/1988 & $<150$ & 61 & 1,988 & 1,355 & 1,367 & LFA & $\mathrm{CHZCM}$ \\
\hline CONTACT & U20aw & $20-57-024$ & 552097.886 & 4126211.4 & 06/22/1989 & $20-150$ & 63 & 2,007 & 1,364 & 1,463 & LFA & $\mathrm{CHZCM}$ \\
\hline CYBAR & U19ar & $19-57-012$ & 557127.293 & 4125777.83 & 07/17/1986 & 119 & 57 & 2,044 & 1,401 & 1,417 & LFA & PLFA \\
\hline DURYEA & U20a1 & $20-57-002$ & 550480.647 & 4121740.04 & $04 / 14 / 1966$ & 70 & 49 & 1,987 & 1,329 & 1,443 & LFA & $\mathrm{CHZCM}$ \\
\hline EGMONT & U20aL & $20-57-014$ & 544546.024 & 4124748.04 & $12 / 09 / 1984$ & $20-150$ & 63 & 1,867 & 1,323 & 1,320 & VTA & PVTA \\
\hline EMMENTHAL & U19t & $19-57-031$ & 562271.495 & 4126843.29 & $11 / 02 / 1978$ & $<20$ & 32 & 2,131 & 1,461 & 1,554 & LFA & $\mathrm{KA}$ \\
\hline ESTUARY & U19g & $19-57-025$ & 556340.474 & 4129243.99 & 03/09/1976 & $200-500$ & 84 & 2,052 & 1,430 & 1,196 & TCU & $\mathrm{BFCU}$ \\
\hline FARM & U20ab & $20-57-004$ & 552284.421 & 4125160.47 & $12 / 16 / 1978$ & $20-150$ & 60 & 2,006 & 1,368 & 1,317 & TCU & CHVCM \\
\hline
\end{tabular}


Table 3-2

Underground Shaft Nuclear Tests Conducted in Central Pahute Mesa (CAU 101)

(Page 2 of 3 )

\begin{tabular}{|c|c|c|c|c|c|c|c|c|c|c|c|c|}
\hline \multirow[b]{2}{*}{ Test Name $\mathrm{e}^{\mathrm{a}}$} & \multirow{2}{*}{ Hole Name ${ }^{a}$} & \multirow{2}{*}{ CAS No. ${ }^{b}$} & \multirow{2}{*}{$\begin{array}{l}\text { Easting }^{c} \\
\quad(\mathrm{~m})\end{array}$} & \multirow{2}{*}{$\begin{array}{l}\text { Northing }^{c} \\
\quad(\mathrm{~m})\end{array}$} & \multirow{2}{*}{$\begin{array}{l}\text { Test } \\
\text { Date }^{a}\end{array}$} & \multirow{2}{*}{$\begin{array}{c}\text { Yield } \\
\text { Range }^{\mathrm{a}} \\
\text { (kt) }\end{array}$} & \multirow{2}{*}{$\begin{array}{l}\text { Calculated } \\
\text { Cavity } \\
\text { Radius }^{\mathrm{d}} \\
(\mathrm{m})\end{array}$} & \multirow{2}{*}{$\begin{array}{c}\text { Land } \\
\text { Surface } \\
\text { Elevation }^{\mathrm{c}} \\
(\mathrm{m} \text { amsl) }\end{array}$} & \multirow{2}{*}{$\begin{array}{l}\text { Water Level } \\
\text { Elevation }^{\mathbf{e}} \\
(\mathrm{m} \text { amsl })\end{array}$} & \multicolumn{3}{|c|}{ Working Point } \\
\hline & & & & & & & & & & $\begin{array}{l}\text { Elevation }^{f} \\
(\mathrm{~m} \text { amsl })\end{array}$ & $\mathrm{HGU}^{\mathrm{g}}$ & HSU $^{\mathrm{h}}$ \\
\hline FONDUTTA & U19zs & 19-57-036 & 559673.51 & 44128120.36 & $04 / 11 / 1978$ & $20-150$ & 61 & 2,099 & 1,449 & 1,466 & 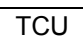 & BFCU \\
\hline GALVESTON & U19af & $19-57-006$ & 556079.061 & 4121450.46 & 09/04/1986 & $<20$ & 33 & 2,045 & 1,365 & 1,558 & LFA & PLFA \\
\hline GIBNE & U20ah & $20-57-010$ & 551224.787 & 4123206.53 & $04 / 25 / 1982$ & $20-150$ & 63 & 1,964 & 1,351 & 1,395 & TCU & $\mathrm{CHZCM}$ \\
\hline GREELEY & U20g & $20-57-037$ & 552440.188 & 4128343.51 & $12 / 20 / 1966$ & 870 & 93 & 1,972 & 1,368 & 756 & $\mathrm{TCU}$ & $\mathrm{BFCU}$ \\
\hline HALFBEAK & U19b & $19-57-018$ & 562117.382 & 4129932.93 & 06/30/1966 & 365 & 77 & 2,070 & 1,448 & 1,251 & WTA & BRA \\
\hline HARDIN & U20av & $20-57-023$ & 551172.747 & 4120677.79 & $04 / 30 / 1987$ & $20-150$ & 61 & 1,970 & 1,326 & 1,345 & TCU & LPCU \\
\hline HARZER & U19aj & $19-57-008$ & 559768.325 & 4128539.07 & 06/06/1981 & $20-150$ & 61 & 2,100 & 1,446 & 1,463 & TCU & BFCU \\
\hline HOSTA & U19ak & $19-57-009$ & 560573.909 & 4133490.59 & $02 / 12 / 1982$ & $20-150$ & 61 & 2,102 & 1,443 & 1,463 & LFA & BRA \\
\hline HOUSTON & U19az & $19-57-017$ & 555779.157 & 4120082.43 & $11 / 14 / 1990$ & $20-150$ & 62 & 2,058 & 1,355 & 1.464 & LFA & PLFA \\
\hline HOYA & U20be & $20-57-031$ & 550733.503 & 4119853.2 & 09/14/1991 & $20-150$ & 60 & 1,979 & 1,315 & 1,321 & TCU & $\mathrm{CHZCM}$ \\
\hline INLET & U19f & $19-57-024$ & 556107.38 & 4119811.47 & $11 / 20 / 1975$ & $200-1,000$ & 108 & 2,053 & 1,352 & 1,234 & TCU & $\mathrm{CHCU}$ \\
\hline JEFFERSON & U20ai & $20-57-011$ & 549637.352 & 4124115.4 & $04 / 22 / 1986$ & $20-150$ & 62 & 1,982 & 1,356 & 1,375 & LFA & $\mathrm{CHZCM}$ \\
\hline JORUM & U20e & $20-57-035$ & 547789.21 & 4129655.07 & $09 / 16 / 1969$ & $<1,000$ & 99 & 1,925 & 1,365 & 766 & TCU & $\mathrm{CHZCM}$ \\
\hline JUNCTION & U19bg & $19-57-020$ & 556762.545 & 4125085.14 & 03/26/1992 & $20-150$ & 61 & 2,040 & 1,394 & 1,418 & LFA & PLFA \\
\hline KAPPELI & U20am & $20-57-015$ & 552255.845 & 4124536 & 07/25/1984 & $20-150$ & 61 & 2,010 & 1,361 & 1,369 & LFA & $\mathrm{CHVCM}$ \\
\hline $\mathrm{KASH}$ & U20af & $20-57-008$ & 548415.607 & 4126054.29 & $06 / 12 / 1980$ & $20-150$ & 61 & 1,938 & 1,349 & 1,294 & LFA & $\mathrm{CHZCM}$ \\
\hline KASSERI & U20z & $20-57-046$ & 552160.289 & 4127007.85 & 10/28/1975 & $200-1,000$ & 97 & 1,984 & 1,366 & 719 & TCU & BFCU \\
\hline KEARSARGE & U19ax & $19-57-015$ & 561462.535 & 4127859.12 & 08/17/1988 & $100-150$ & 61 & 2,129 & 1,454 & 1,514 & LFA & $\mathrm{KA}$ \\
\hline KERNVILLE & U20ar & $20-57-020$ & 546832.3 & 4129681.86 & $02 / 15 / 1988$ & $20-150$ & 63 & 1,926 & 1,373 & 1,384 & VTA & PVTA \\
\hline LABQUARK & U19an & $19-57-010$ & 561381.251 & 4128183.06 & 09/30/1986 & $20-150$ & 61 & 2,127 & 1,453 & 1,511 & LFA & $\mathrm{KA}$ \\
\hline LOCKNEY & U19aq & $19-57-011$ & 555471.477 & 4120144.12 & $09 / 24 / 1987$ & $20-150$ & 61 & 2,072 & 1,354 & 1,458 & LFA & PLFA \\
\hline MAST & U19u & $19-57-032$ & 560207.323 & 4133751.35 & $06 / 19 / 1975$ & $200-1,000$ & 105 & 2,095 & 1,444 & 1,184 & LFA & BRA \\
\hline MONTELLO & U20bf & $20-57-032$ & 549522.46 & 4122042.6 & $04 / 16 / 1991$ & $20-150$ & 61 & 1,988 & 1,341 & 1,346 & TCU & $\mathrm{CHZCM}$ \\
\hline MUENSTER & U19e & 19-57-023 & 559100.938 & 4127774.92 & 01/03/1976 & $200-1,000$ & 93 & 2,109 & 1,442 & 657 & WTA & BRA \\
\hline
\end{tabular}


Table 3-2

Underground Shaft Nuclear Tests Conducted in Central Pahute Mesa (CAU 101)

(Page 3 of 3 )

\begin{tabular}{|c|c|c|c|c|c|c|c|c|c|c|c|c|}
\hline \multirow{2}{*}{ Test Name ${ }^{a}$} & \multirow{2}{*}{ Hole Name ${ }^{a}$} & \multirow{2}{*}{ CAS No. ${ }^{b}$} & \multirow{2}{*}{$\begin{array}{l}\text { Easting }^{c} \\
(\mathrm{~m})\end{array}$} & \multirow{2}{*}{$\begin{array}{l}\text { Northing } \\
\text { (m) }\end{array}$} & \multirow{2}{*}{$\begin{array}{l}\text { Test } \\
\text { Date }^{a}\end{array}$} & \multirow{2}{*}{$\begin{array}{c}\text { Yield } \\
\text { Range }^{\mathrm{a}} \\
(\mathrm{kt})\end{array}$} & \multirow{2}{*}{$\begin{array}{l}\text { Calculated } \\
\text { Cavity } \\
\text { Radius }^{\mathrm{d}} \\
(\mathrm{m})\end{array}$} & \multirow{2}{*}{$\begin{array}{c}\text { Land } \\
\text { Surface } \\
\text { Elevation } \\
(\mathrm{m} \text { amsl })\end{array}$} & \multirow{2}{*}{$\begin{array}{c}\text { Water Level } \\
\text { Elevation } \\
(\mathrm{m} \text { amsl) }\end{array}$} & \multicolumn{3}{|c|}{ Working Point } \\
\hline & & & & & & & & & & $\begin{array}{c}\text { Elevation }^{f} \\
(\mathrm{~m} \text { amsl })\end{array}$ & $\mathrm{HGU}^{\mathrm{g}}$ & HSU $^{h}$ \\
\hline NEBBIOLO & U19ae & 19-57-005 & 555867.135 & 4121059.06 & $06 / 24 / 1982$ & $20-150$ & 61 & 2,065 & 1,361 & 1,426 & LFA & PLFA \\
\hline PANIR & U19ys & $19-57-035$ & 556975.703 & 4125472.58 & $08 / 31 / 1978$ & $20-150$ & 60 & 2,040 & 1,398 & 1,359 & LFA & PLFA \\
\hline PEPATO & U20ad & $20-57-006$ & 548286.316 & 4126944.52 & $06 / 11 / 1979$ & $20-150$ & 60 & 1,940 & 1,356 & 1,258 & TCU & $\mathrm{CHZCM}$ \\
\hline PIPKIN & U20b & $20-57-027$ & 549594.537 & 4123294.03 & $10 / 08 / 1969$ & $200-1,000$ & 115 & 1,992 & 1,354 & 1,368 & LFA & $\mathrm{CHZCM}$ \\
\hline POOL & U19p & $19-57-029$ & 559541.604 & 4123266.91 & $03 / 17 / 1976$ & $200-500$ & 84 & 2,103 & 1,413 & 1,222 & $\mathrm{TCU}$ & $\mathrm{BFCU}$ \\
\hline REX & $\mathrm{U} 20 \mathrm{~h}(\mathrm{e})$ & $20-57-038$ & 550196.529 & 4124975.16 & $02 / 24 / 1966$ & 19 & 30 & 1,999 & 1,357 & 1,327 & TCU & $\mathrm{CHZCM}$ \\
\hline RICKEY & U19c & $19-57-021$ & 560769.426 & 4124276.51 & $06 / 15 / 1968$ & $20-200$ & 66 & 2,143 & 1,435 & 1,460 & VTA & CHVTA \\
\hline SCOTCH & U19as & $19-57-013$ & 555856.824 & 4125370.82 & $05 / 23 / 1967$ & 155 & 55 & 2,061 & 1,395 & 1,083 & TCU & CFCU \\
\hline SCROLL & U19n & $19-57-028$ & 555314.008 & 4132315.3 & $04 / 23 / 1968$ & $<20$ & 40 & 2,059 & 1,456 & 1,833 & CHVCM & VTA \\
\hline SERENA & U20an & $20-57-016$ & 549804.18 & 4127791.81 & $07 / 25 / 1985$ & $20-150$ & 62 & 1,970 & 1,359 & 1,372 & LFA & $\mathrm{CHZCM}$ \\
\hline SERPA & U19ai & $19-57-007$ & 560675.009 & 4130919.1 & $12 / 17 / 1980$ & $20-150$ & 63 & 2,055 & 1,444 & 1,482 & TCU & $\mathrm{BFCU}$ \\
\hline SHEEPSHEAD & U19aa & $19-57-001$ & 556415.668 & 4120269.64 & $09 / 26 / 1979$ & $20-150$ & 61 & 2,060 & 1,361 & 1,420 & LFA & PLFA \\
\hline SLED & U19i & $19-57-026$ & 557922.096 & 4122637.74 & $08 / 29 / 1968$ & $20-200$ & 65 & 2,084 & 1,396 & 1,355 & TCU & CFCU \\
\hline STINGER & U19l & $19-57-027$ & 561067.775 & 4131788.33 & $03 / 22 / 1968$ & $20-200$ & 66 & 2,062 & 1,442 & 1,394 & LFA & BRA \\
\hline TIERRA & U19ac & $19-57-003$ & 561575.056 & 4126107.67 & $12 / 15 / 1984$ & $20-150$ & 61 & 2,145 & 1,459 & 1,505 & LFA & $\mathrm{KA}$ \\
\hline TOWANDA & U19ab & $19-57-002$ & 559842.413 & 4122993.41 & $05 / 02 / 1985$ & $20-150$ & 60 & 2,112 & 1,415 & 1,451 & TCU & BFCU \\
\hline
\end{tabular}

${ }^{a}$ Source: DOE/NV, 2000

cSource: UGTA Borehole Index (in UTM, Zone 11, NAD 27)

${ }^{d}$ Calculated Cavity Radii $=\left[70.2^{*}(y)^{1 / 3}\right] /\left(\rho_{b}{ }^{*} \mathrm{DOB}\right)^{1 / 4}$ where $y=$ yield of the test $(\mathrm{kt}), \rho_{\mathrm{b}}=$ bulk density of the overburden $\left(\mathrm{g} / \mathrm{cm}^{3}\right)$, and DOB = Depth of Burial of the working point $(\mathrm{m})($ taken from Pawloski $[1999])$

e Source: BN, 2002

fWorking Point Elevation = Land Surface Elevation - Working Point Depth (taken from Pawloski, 2004)

${ }^{9}$ Hydrogeologic Unit (See Appendix A); BN, 2002

$h_{\text {Hydrostratigraphy (See Appendix A); BN, } 2002}$

HGU - Hydrogeologic unit

HSU - Hydrostratigraphic unit

amsl - Above mean sea level 
Table 3-3

Underground Shaft Nuclear Tests Conducted in Western Pahute Mesa (CAU 102)

\begin{tabular}{|c|c|c|c|c|c|c|c|c|c|c|c|c|}
\hline \multirow[b]{2}{*}{ Test Name ${ }^{a}$} & \multirow[b]{2}{*}{ Hole Name ${ }^{a}$} & \multirow[b]{2}{*}{ CAS No. ${ }^{b}$} & \multirow[b]{2}{*}{$\begin{array}{l}\text { Easting }^{\mathrm{c}} \\
(\mathrm{m})\end{array}$} & \multirow[b]{2}{*}{$\begin{array}{l}\text { Northing } \\
(\mathrm{m})\end{array}$} & \multirow[b]{2}{*}{$\begin{array}{l}\text { Test } \\
\text { Date }^{a}\end{array}$} & \multirow{2}{*}{$\begin{array}{c}\begin{array}{c}\text { Yield } \\
\text { Range } \\
\text { (kt) }\end{array}\end{array}$} & \multirow{2}{*}{$\begin{array}{c}\text { Calculated } \\
\text { Cavity } \\
\text { Radius }^{\mathrm{d}} \\
(\mathrm{m})\end{array}$} & \multirow{2}{*}{$\begin{array}{c}\text { Land } \\
\text { Surface } \\
\text { Elevation } \\
(\mathrm{m} \text { amsl) }\end{array}$} & \multirow{2}{*}{$\begin{array}{l}\text { Water Level } \\
\text { Elevatione } \\
\text { (m amsl) }\end{array}$} & \multicolumn{3}{|c|}{ Working Point } \\
\hline & & & & & & & & & & $\begin{array}{c}\text { Elevation }^{f} \\
(\mathrm{~m} \text { amsl })\end{array}$ & $\mathrm{HGU}^{\mathrm{g}}$ & HSU $^{h}$ \\
\hline BELMONT & U20as & $20-57-021$ & 547764.676 & 4119233.62 & $10 / 16 / 1986$ & $20-150$ & 62 & 1,898 & 1,289 & 1,293 & $\mathrm{TCU}$ & UPCU \\
\hline BENHAM & U20c & $20-57-033$ & 546698.659 & 4120477.68 & $12 / 19 / 1968$ & 1150 & 99 & 1,914 & 1,285 & 512 & TCU & $\mathrm{CHZCM}$ \\
\hline BUTEO & U20a & $20-57-001$ & 550480.647 & 4121740.04 & $05 / 12 / 1965$ & $<20$ & 30 & 1,987 & 1,339 & 1,292 & $\mathrm{TCU}$ & $\mathrm{CHZCM}$ \\
\hline $\begin{array}{l}\text { CHA- } \\
\text { TEAUGAY }\end{array}$ & $\mathrm{U} 20 \mathrm{t}$ & $20-57-043$ & 545866.189 & 4122030.04 & $06 / 28 / 1968$ & $20-200$ & 68 & 1,903 & 1,287 & 1,296 & LFA & BA \\
\hline DARWIN & U20aq & 20-57-019 & 544396.119 & 4124138.08 & $06 / 25 / 1986$ & $20-150$ & 63 & 1,876 & 1,315 & 1,327 & TCU & UPCU \\
\hline DELAMAR & U20at & $20-57-022$ & 543533.91 & 4122280.83 & $04 / 18 / 1987$ & $20-150$ & 63 & 1,902 & 1,297 & 1,358 & TCU & UPCU \\
\hline FONTINA & U20f & $20-57-036$ & 545355.123 & 4124900.2 & 02/12/1976 & $200-1,000$ & 98 & 1,864 & 1,326 & 646 & $\mathrm{TCU}$ & $\mathrm{CHZCM}$ \\
\hline $\begin{array}{l}\text { GOLD- } \\
\text { STONE }\end{array}$ & U20ao & $20-57-017$ & 546767.795 & 4121180 & $12 / 28 / 1985$ & $20-150$ & 63 & 1,914 & , 1287 & 1,365 & LFA & $\mathrm{BA}$ \\
\hline HANDLEY & $\mathrm{U} 20 \mathrm{~m}$ & $20-57-040$ & 541289.565 & 4128104.3 & $03 / 26 / 1970$ & $>1,000$ & 98 & 1,799 & 1,041 & 590 & TCU & PBRCM \\
\hline HORNITOS & $\mathrm{U} 20 \mathrm{bc}$ & $20-57-029$ & 545158.173 & 4123977.74 & $10 / 31 / 1989$ & $20-150$ & 63 & 1,873 & 1,306 & 1,309 & VTA & PVTA \\
\hline $\begin{array}{l}\text { KNICKER- } \\
\text { BOCKER }\end{array}$ & U20d & $20-57-034$ & 546102.61 & 4122300.85 & $05 / 26 / 1967$ & 76 & 49 & 1,906 & 1,293 & 1,273 & LFA & BA \\
\hline MOLBO & U20ag & 20-57-009 & 547671.959 & 4119690.06 & 02/12/1982 & $20-150$ & 61 & 1,900 & 1,290 & 1,262 & LFA & $\mathrm{BA}$ \\
\hline PURSE & U20v & $20-57-044$ & 544266.773 & 4126168.56 & 05/07/1969 & $20-200$ & 68 & 1,856 & 1,351 & 1,257 & TCU & UPCU \\
\hline SALUT & U20ak & $20-57-013$ & 545315.269 & 4122286.8 & $06 / 12 / 1985$ & $20-150$ & 62 & 1,900 & 1,288 & 1,292 & LFA & $\mathrm{BA}$ \\
\hline STILTON & U20p & $20-57-042$ & 542263.782 & 4132499.92 & 06/03/1975 & $20-200$ & 65 & 1,695 & 1,423 & 963 & UNK & PBRCM \\
\hline TAFI & U20ae & $20-57-007$ & 546343.106 & 4123232 & $07 / 25 / 1980$ & $20-150$ & 60 & 1,886 & 1,302 & 1,206 & VTA & PVTA \\
\hline TENABO & U20bb & $20-57-028$ & 544857.893 & 4122285.19 & $10 / 12 / 1990$ & $20-150$ & 62 & 1,898 & 1,289 & 1,298 & VTA & PVTA \\
\hline TYBO & U20y & $20-57-045$ & 546651.338 & 4119290.95 & $05 / 14 / 1975$ & $200-1,000$ & 110 & 1,907 & 1,283 & 1,142 & WTA & TSA \\
\hline
\end{tabular}

${ }^{a}$ Source: DOE/NV, 2000

Source: FFACO, 1996

'Source: UGTA Borehole Index (in UTM, Zone 11, NAD 27)

${ }^{d}$ Calculated Cavity Radius $=\left[70.2^{*}(\mathrm{y})^{1 / 3}\right] /\left(\rho_{\mathrm{b}}{ }^{*} \mathrm{DOB}\right)^{1 / 4}$ where $\mathrm{y}=$ yield of the test $(\mathrm{kt}), \rho_{\mathrm{b}}=$ bulk density of the overburden $\left(\mathrm{g} / \mathrm{cm}^{3}\right)$, and DOB $=$ Depth of Burial of the working point $(\mathrm{m})[$ taken from Pawloski (1999)]

'Working Point Elevation $=$ Land Surface Elevation - Working Point Depth (taken from Pawloski, 2004)

9Hydrogeologic Unit (See Appendix A); BN, 2002

Hydrostratigraphy (See Appendix A); BN, 2002

HGU - Hydrogeologic unit

HSU - Hydrostratigraphic unit 
underground nuclear tests is presented followed by a description of the phenomenological models recently developed for Pahute Mesa underground nuclear tests.

\subsubsection{Phenomenology of an Underground Nuclear Explosion}

This section includes an overview of the phenomenology of an underground nuclear explosion, followed by a description of the resulting distribution of materials introduced to the subsurface.

\section{Phenomenology Overview}

The testing of an underground nuclear explosion resulted in successive, physical phenomena that occurred within measured time frames. The time frames and corresponding phenomena that occur are described based on a report prepared by the U.S. Congress, Office of Technology Assessment (1989).

- Within microseconds (one-millionth of a second), billions of atoms release their energy, which results in the creation of a powerful shock wave that spreads outward from the point of origin.

- Within tens of milliseconds (thousandths of a second), vaporization occurs that forms high-pressure steam and gas in the shape of a bubble that results in the formation of a cavity.

- Within tenths of a second, an expanded cavity and reduced internal pressure are evident. After a few tenths of a second, the cavity reaches its fullest potential in terms of its growth. The shock wave generated by the explosion, fractures and crushes the rock as it extends outward from the cavity. The shock wave eventually loses its strength and momentum and becomes too weak to continue to crush rock. Thus, the crushed rock is characterized by a compression and relaxation phase that results in seismic waves that move through the earth.

- Within a few seconds, molten rock collects, solidifies, and forms at the bottom of the cavity. Cooling results in a decrease in the cavity's gas pressure.

- Within minutes to days, cavity collapse occurs because of the decreased gas pressure, which causes the overlying rock that supports the cavity to weaken. A process referred to, as "chimneying" is a result of rock debris and loose rubble falling into the cavity causing the void area to move upward. "Chimneying" is continuous until one of the following occurs to the void region: (1) the void becomes completely filled with loose rubble, (2) the void's shape in conjunction with the stability of the rock can sustain the overloaded material or (3) the chimney approaches ground surface. 
Other phenomena related to underground nuclear testing have occurred, including hydrofracturing, prompt injection of radionuclides, groundwater effects (such as mounding and pressurization), reflections off of impedance layers caused by material property differences (such as rock strength or air void content, bedding planes, or faults), and movement on preexisting structural features (such as faults). These may affect cavity growth, residual stress, collapse, and crater formation.

\section{Distribution of Materials Related to Testing}

The nuclear explosion phenomenology described above is responsible for the observed distribution of materials that were introduced into the subsurface during testing. Radioactive elements are not uniformly distributed in the chimney/cavity region, but are partitioned based on their physical and chemical characteristics.

Smith (1993) indicates that the partitioning can be described in terms of a three stage condensation process. The refractory radionuclides (e.g., actinides), whose melting points are significantly greater than the melting temperature of the adjacent geologic media, are scavenged by the molten material that lines the cavity. These nuclides are volumetrically deposited within the melt glass. Further condensation occurs as cavity gas moves into the crushed rubble and fractured material surrounding the working point. During this stage, the radioisotopes of intermediate volatility, often with gaseous precursors (e.g., cesium-137 $\left[{ }^{137} \mathrm{Cs}\right]$ ), condense and deposit on rubble and fracture surfaces. Final condensation occurs as residual gas ascends toward the ground surface. Condensation during this stage also occurs on surfaces. The above process leads to a distribution of radionuclides that is fractionated, with heavier refractory nuclides concentrated within the melt glass and lighter and volatile nuclides concentrated higher in the chimney (Smith, 1993). Tritium initially is distributed in the gas phase and later as molecular tritium oxide in steam (Smith, 1995a).

During tests conducted at or below the water table, groundwater is evacuated from the test cavity and then slowly seeps back into the cavity after the detonation (Borg et al., 1976). Where detonations are near or below the static water level, groundwater is impacted due to the prompt injection of radionuclides into surrounding fractures or the leaching of radionuclides as water seeps back into the test cavity and rubble chimney.

The distribution of radionuclides in the cavity/chimney region greatly influences the availability of potential contaminants for transport by groundwater.

Radionuclides volumetrically incorporated in the melt glass matrix are accessible to groundwater only through slow processes such as melt glass dissolution. Other radionuclides are predominantly associated with surfaces and are accessible to groundwater through relatively fast processes such as ion exchange (Smith, 1995b).

In addition, metals, drilling mud, and other organic material may be left within, or in close proximity to, the chimney or test cavity due to reentry operations. Nonradiological contaminants from these sources can also be leached into groundwater and potentially transported to environmental receptors. 


\subsubsection{Phenomenological Models of Underground Nuclear Test on Pahute Mesa}

In support of the Pahute Mesa CAI, Pawloski (1999) developed phenomenological models for the BENHAM and TYBO underground nuclear tests.

The main goal of this study was to identify the modifications to the media at a pertinent scale in support of modeling radionuclide transport at near-field and intermediate-field scales in Pahute Mesa (Pawloski, 1999).

The results are expressed as phenomenological models for the BENHAM and TYBO underground nuclear tests. Phenomenological models are conceptual models of the near-field region. They are subdivided into four components: the puddle region, the cavity region, the damage region, and the chimney region. The models provide detailed information about each of the components including geometry, volumes, and material properties. Phenomenological model parameters that are useful for radionuclide transport modeling at the intermediate and CAU scales include the geometry of each of the components, and estimations of relative permeabilities for each of the components.

The detailed phenomenological models developed for the BENHAM and TYBO underground nuclear tests may be found in the report prepared by Pawloski (1999). Parameters describing these phenomenologic models for input to groundwater flow and transport models at the intermediate and CAU scales are presented in Table 3-4. Zones for the cavity and volume of rock permanently damaged have been included as part of the outgoing shockwave and chimney dimensions (Pawloski, 1999).

Table 3-4

Phenomenologic Models for BENHAM and TYBO

\begin{tabular}{|c|c|c|c|c|}
\hline \multirow{2}{*}{$\begin{array}{c}\text { Phenomenological } \\
\text { Model Components }\end{array}$} & BENHAM & \multicolumn{2}{c|}{ Permeability } \\
\cline { 2 - 5 } & TYBO & BENHAM & TYBO \\
\hline \hline Puddle Region & $\begin{array}{c}8.05 \times 10^{5} \text { megagrams }(\mathrm{Mg}) \text { melt } \\
\text { glass over lower cavity }\end{array}$ & $\begin{array}{c}7.0 \times 10^{5} \mathrm{Mg} \text { melt glass } \\
\text { over lower cavity }\end{array}$ & $\begin{array}{c}\text { Lower than } \\
\text { pretest }\end{array}$ & $\begin{array}{c}\text { Lower than } \\
\text { pretest }\end{array}$ \\
\hline Cavity Region & 99 -m radius sphere & 112 -m radius & $\begin{array}{c}\text { Higher than } \\
\text { pretest }\end{array}$ & $\begin{array}{c}\text { Higher than } \\
\text { pretest }\end{array}$ \\
\hline Damage Region & 297 -m radius sphere & $224-m$ radius & $\begin{array}{c}\text { Higher than } \\
\text { pretest }\end{array}$ & $\begin{array}{c}\text { Higher than } \\
\text { pretest }\end{array}$ \\
\hline Chimney Region & $\begin{array}{c}99-m \text { radius cylinder from } \\
\text { working point to } 640 \mathrm{~m}\end{array}$ & Outside saturated area & $\begin{array}{c}\text { Higher than } \\
\text { pretest }\end{array}$ & Not applicable \\
\hline
\end{tabular}

\footnotetext{
${ }^{\mathrm{a}}$ The phenomenological model for TYBO is for a maximum yield of 1,000 kt.
}

Source: Pawloski, 1999 


\subsection{Unclassified Radionuclide Inventory}

The most recent inventory of the radionuclide source term may be found in a report titled, "Nevada Test Site Radionuclide Inventory, 1951-1992"

(Bowen et al., 2001). The inventory includes radionuclides produced by the 828 underground nuclear tests conducted at the NTS between 1951 and 1992. The inventory was subdivided into five areas roughly corresponding to the UGTA CAUs. The inventory for Yucca Flat was further subdivided by tests based on the depth of the working point relative to that of the water table. The inventory for Pahute Mesa was subdivided by NTS area. The inventory includes tritium, fission products, actinides, and activation products and provides an estimate of radioactivity remaining underground after nuclear testing.

The list of nuclides including the remaining radioactivity values for Areas 19 and 20 of Pahute Mesa is provided in Table 3-5. The list includes 43 radiological contaminants that have half-lives greater than 10 years (with the exception of Europium-154 $\left.\left[{ }^{154} \mathrm{Eu}\right]\right)$. Criteria for inclusion of radionuclides in the inventory may be found in the report prepared by Bowen et al. (2001). Remaining radioactivity values have been decay-corrected to September 23, 1992, the date of the last underground nuclear test. The estimated accuracies for individual nuclides are provided in Table 3-6 by group of nuclides, as reported by Bowen et al. (2001).

The list of radionuclides provided in Table 3-5 serves as the preliminary list of potential contaminants for the Pahute Mesa CAUs. This lists supersedes the list of potential contaminants presented in the Pahute Mesa Corrective Action Investigation Plan (CAIP) (DOE/NV, 1999). Note that lead had previously been included in the list of potential contaminants for the Pahute Mesa CAUs because it is known to have been used in significant quantities in underground nuclear tests (DOE/NV, 1999). Lead has since been deleted from the list because it has not been found in groundwater samples.

\subsection{Radionuclide Distribution in the Subsurface}

Information available on radionuclide distribution within the subsurface include observed radionuclide activities from analysis of groundwater samples and various reports containing evaluations of the sampling data. The groundwater sampling data and the findings of several reports that are pertinent to the HST are discussed in this section. Reports containing results of evaluations of the radiochemistry of cavity water, groundwater samples, and the closed system behavior of selected cavities are summarized in this section.

\subsubsection{Groundwater Sampling Data}

Observed radionuclide concentrations in groundwater samples may be used to constrain or validate predictions made by transport models. Groundwater sampling data for the NTS and vicinity are available from various programs sponsored by NNSA/NSO and other organizations. Groundwater sample analysis 
Table 3-5

Radionuclide Inventory for Areas 19 and 20 of the Nevada Test Site

\begin{tabular}{|c|c|c|c|c|}
\hline \multirow{2}{*}{ Radionuclide } & Curies $^{a}$ & Atoms $^{a}$ & Curies $^{a}$ & Atoms $^{a}$ \\
\hline & Area 19 & Area 19 & Area 20 & Area 20 \\
\hline${ }^{3} \mathrm{H}$ & $1.778 \mathrm{E}+07$ & $3.689 \mathrm{E}+26$ & $5.903 \mathrm{E}+07$ & $1.225 \mathrm{E}+27$ \\
\hline${ }^{14} \mathrm{C}$ & $2.193 \mathrm{E}+02$ & $2.111 \mathrm{E}+24$ & $4.693 \mathrm{E}+02$ & $4.518 \mathrm{E}+24$ \\
\hline${ }^{26} \mathrm{Al}$ & 8.975E-04 & $1.073 \mathrm{E}+21$ & 8.370E-03 & $1.001 \mathrm{E}+22$ \\
\hline${ }^{36} \mathrm{Cl}$ & $9.108 \mathrm{E}+01$ & $4.618 \mathrm{E}+25$ & $1.573 \mathrm{E}+02$ & $7.973 \mathrm{E}+25$ \\
\hline${ }^{39} \mathrm{Ar}$ & $6.398 \mathrm{E}+02$ & $2.899 \mathrm{E}+23$ & $1.247 \mathrm{E}+03$ & $5.652 \mathrm{E}+23$ \\
\hline${ }^{40} \mathrm{~K}$ & $1.588 \mathrm{E}+02$ & $3.398 \mathrm{E}+29$ & $3.171 \mathrm{E}+02$ & $6.783 \mathrm{E}+29$ \\
\hline${ }^{41} \mathrm{Ca}$ & $5.050 \mathrm{E}+02$ & $8.763 \mathrm{E}+25$ & $1.273 \mathrm{E}+03$ & $2.208 \mathrm{E}+26$ \\
\hline${ }^{59} \mathrm{Ni}$ & $1.596 \mathrm{E}+01$ & $2.043 E+24$ & $2.976 \mathrm{E}+01$ & $3.810 \mathrm{E}+24$ \\
\hline${ }^{63} \mathrm{Ni}$ & $1.724 \mathrm{E}+03$ & $2.904 \mathrm{E}+23$ & $3.126 \mathrm{E}+03$ & $5.266 \mathrm{E}+23$ \\
\hline${ }^{85} \mathrm{Kr}$ & $4.981 \mathrm{E}+04$ & $9.028 \mathrm{E}+23$ & $5.706 \mathrm{E}+04$ & $1.034 \mathrm{E}+24$ \\
\hline${ }^{90} \mathrm{Sr}$ & $5.804 \mathrm{E}+05$ & $2.814 \mathrm{E}+25$ & $6.835 \mathrm{E}+05$ & $3.314 \mathrm{E}+25$ \\
\hline${ }^{93} \mathrm{Zr}$ & $1.887 \mathrm{E}+01$ & $4.767 \mathrm{E}+25$ & $2.372 \mathrm{E}+01$ & $5.993 \mathrm{E}+25$ \\
\hline${ }^{93 \mathrm{~m}} \mathrm{Nb}$ & $2.969 \mathrm{E}+03$ & $8.053 E+22$ & $5.100 \mathrm{E}+03$ & $1.383 \mathrm{E}+23$ \\
\hline${ }^{94} \mathrm{Nb}$ & $7.938 \mathrm{E}+01$ & $2.674 \mathrm{E}+24$ & $9.852 \mathrm{E}+01$ & $3.319 \mathrm{E}+24$ \\
\hline${ }^{99} \mathrm{Tc}$ & $1.344 \mathrm{E}+02$ & $4.821 \mathrm{E}+25$ & $1.782 \mathrm{E}+02$ & $6.394 \mathrm{E}+25$ \\
\hline${ }^{107} \mathrm{Pd}$ & 5.957E-01 & $6.523 E+24$ & $1.002 \mathrm{E}+00$ & $1.097 \mathrm{E}+25$ \\
\hline${ }^{113 m} \mathrm{Cd}$ & $5.017 \mathrm{E}+02$ & 1.192E+22 & $7.469 \mathrm{E}+02$ & $1.774 \mathrm{E}+22$ \\
\hline${ }^{121 \mathrm{~m}} \mathrm{Sn}$ & $1.782 \mathrm{E}+03$ & $1.651 \mathrm{E}+23$ & $2.667 \mathrm{E}+03$ & $2.470 \mathrm{E}+23$ \\
\hline${ }^{126} \mathrm{Sn}$ & $8.085 \mathrm{E}+00$ & $3.405 E+24$ & $1.188 \mathrm{E}+01$ & $5.002 \mathrm{E}+24$ \\
\hline 129 & 4.153E-01 & $1.098 \mathrm{E}+25$ & $5.596 \mathrm{E}-01$ & $1.480 \mathrm{E}+25$ \\
\hline${ }^{135} \mathrm{Cs}$ & $1.393 \mathrm{E}+01$ & $5.397 \mathrm{E}+25$ & $1.838 \mathrm{E}+01$ & $7.120 \mathrm{E}+25$ \\
\hline${ }^{137} \mathrm{Cs}$ & $6.971 \mathrm{E}+05$ & $3.531 \mathrm{E}+25$ & $8.957 E+05$ & $4.537 \mathrm{E}+25$ \\
\hline${ }^{151} \mathrm{Sm}$ & $2.307 \mathrm{E}+04$ & $3.498 \mathrm{E}+24$ & $3.568 \mathrm{E}+04$ & $5.409 \mathrm{E}+24$ \\
\hline${ }^{150} \mathrm{Eu}$ & $7.805 \mathrm{E}+01$ & $4.733 E+21$ & $1.069 \mathrm{E}+03$ & $6.483 E+22$ \\
\hline${ }^{152} \mathrm{Eu}$ & $\mathrm{I} .151 \mathrm{E}+04$ & $2.626 \mathrm{E}+23$ & $2.970 \mathrm{E}+04$ & $6.774 \mathrm{E}+23$ \\
\hline${ }^{154} \mathrm{Eu}$ & $7.099 \mathrm{E}+03$ & $1.028 \mathrm{E}+23$ & $1.327 \mathrm{E}+04$ & $1.921 \mathrm{E}+23$ \\
\hline${ }^{166 \mathrm{~m}} \mathrm{Ho}$ & $3.083 E+01$ & $6.231 \mathrm{E}+22$ & $2.892 \mathrm{E}+01$ & $5.846 \mathrm{E}+22$ \\
\hline${ }^{232} \mathrm{Th}$ & 1.147E+0I & $2.706 E+29$ & $2.319 \mathrm{E}+01$ & $5.468 \mathrm{E}+29$ \\
\hline${ }^{232} \mathrm{U}$ & $8.730 \mathrm{E}+01$ & $1.026 \mathrm{E}+22$ & $1.738 E+02$ & $2.044 \mathrm{E}+22$ \\
\hline${ }^{233} \mathrm{U}$ & $6.508 \mathrm{E}+01$ & $1.745 E+25$ & $1.176 \mathrm{E}+02$ & $3.154 \mathrm{E}+25$ \\
\hline${ }^{234} U$ & $1.421 \mathrm{E}+02$ & $5.888 E+25$ & $1.179 \mathrm{E}+02$ & $4.885 \mathrm{E}+25$ \\
\hline${ }^{235} \mathrm{U}$ & $1.293 \mathrm{E}+00$ & $1.533 E+27$ & $1.343 \mathrm{E}+00$ & $1.592 \mathrm{E}+27$ \\
\hline${ }^{236} U$ & $2.213 \mathrm{E}+00$ & $8.730 E+25$ & $2.647 \mathrm{E}+00$ & $1.044 \mathrm{E}+26$ \\
\hline${ }^{238} \mathrm{U}$ & $6.826 \mathrm{E}+00$ & $5.140 \mathrm{E}+28$ & $1.250 \mathrm{E}+01$ & $9.411 \mathrm{E}+28$ \\
\hline${ }^{237} \mathrm{~Np}$ & 1.196E+0I & $4.310 \mathrm{E}+25$ & $2.476 \mathrm{E}+01$ & $8.923 \mathrm{E}+25$ \\
\hline${ }^{238} \mathrm{Pu}$ & $2.857 \mathrm{E}+03$ & $4.220 \mathrm{E}+23$ & $4.768 E+03$ & $7.043 E+23$ \\
\hline${ }^{239} \mathrm{Pu}$ & $7.684 \mathrm{E}+03$ & $3.119 \mathrm{E}+26$ & $1.262 \mathrm{E}+04$ & $5.123 E+29$ \\
\hline${ }^{240} \mathrm{Pu}$ & $2.041 \mathrm{E}+03$ & $2.256 \mathrm{E}+25$ & $4.405 \mathrm{E}+03$ & $4.867 \mathrm{E}+25$ \\
\hline${ }^{241} \mathrm{Pu}$ & $2.946 \mathrm{E}+04$ & $7.145 \mathrm{E}+23$ & $6.952 \mathrm{E}+04$ & $1.686 \mathrm{E}+24$ \\
\hline${ }^{242} \mathrm{Pu}$ & $1.367 \mathrm{E}+00$ & $8.637 \mathrm{E}+23$ & $2.279 \mathrm{E}+00$ & $1.440 \mathrm{E}+24$ \\
\hline${ }^{241} \mathrm{Am}$ & $1.299 \mathrm{E}+03$ & $9.468 \mathrm{E}+23$ & $3.567 \mathrm{E}+03$ & $2.600 \mathrm{E}+24$ \\
\hline${ }^{243} \mathrm{Am}$ & 1.203E-02 & $1.493 \mathrm{E}+20$ & 1.772E-01 & $2.200 \mathrm{E}+21$ \\
\hline${ }^{244} \mathrm{Cm}$ & $1.190 \mathrm{E}+03$ & $3.629 E+22$ & $2.197 E+03$ & $6.700 \mathrm{E}+22$ \\
\hline Total & $1.920 \mathrm{E}+07$ & $6.646 E+29$ & $6.086 \mathrm{E}+07$ & $1.324 \mathrm{E}+30$ \\
\hline
\end{tabular}

${ }^{a}$ Decay-Corrected to September 23, 1992 (date of last underground nuclear test)

Source: Bowen et al., 2001 
Table 3-6

Estimated Accuracies for Individual Nuclides in the Various Groups of Radionuclides

\begin{tabular}{|c|c|}
\hline Radionuclide Group & Accuracy \\
\hline \hline Fission Products & $\sim 10$ to 30 percent \\
\hline Unspent Fuel Materials & $\sim 20$ percent or better \\
\hline Fuel Activation Products & $\sim 50$ percent or better \\
\hline Residual Tritium & $\sim 300$ percent or better \\
\hline Activation Products & $\sim$ a factor of 10 \\
\hline
\end{tabular}

Source: Bowen et al., 2001

results are stored and maintained in a centralized and comprehensive water chemistry database, GeoChem (IT, 2002a). This database was developed under the UGTA Project to support the environmental restoration activities of the underground test areas of the NTS. A brief description of the GeoChem database is provided in Appendix C. Details may be found in the GeoChem database user's guide (IT, 2002a).

Data on observed radionuclide activities in groundwater are available for various groundwater sites including boreholes and springs located within the PM-OV area. Many of the observed radionuclide activities are representative of normal environmental levels (tritium in Oasis Valley, for example) and are not indicative of contamination from underground nuclear tests. Section 6.0 provides a more detailed discussion of the available radionuclide data for the PM-OV area including cavity sampling.

\subsubsection{Radiochemistry of Cavity Water}

Smith (2002) conducted an evaluation of the radiochemistry of near-field water samples at the NTS. Smith (2002) defined "near-field" as including "the area extending radially 300 meters from surface ground zero (the firing point of an underground nuclear test projected upwards to the earth's surface)." The purpose of this evaluation was to summarize historical near-field data collection activities at the NTS, to describe the hydrogeologic and radiochemical environment of near-field sampling locations, to assemble a representative set of near-field radiochemical data, to review prior analyses of the data, and to assess the usability of the data in the development of a hydrologic source term.

Of the limited number of wells sampled, only three (CAMBRIC, CHESHIRE, and ALMENDRO) produce water from the cavity region. However, the results from the limited sampling events have provided valuable information. Conclusions of this evaluation are as follows:

- Widespread groundwater contamination from the underground nuclear tests is unlikely. 
- Soluble radionuclides: tritium $\left({ }^{3} \mathrm{H}\right)$, carbon-14 $\left({ }^{14} \mathrm{C}\right)$, chlorine-36 $\left({ }^{36} \mathrm{Cl}\right)$, krypton-85 $\left({ }^{85} \mathrm{Kr}\right)$, technetium-99 $\left({ }^{99} \mathrm{Tc}\right)$, and iodine-129 $\left({ }^{129} \mathrm{I}\right)$ are found as dissolved species and scale proportionately to the activities of tritium. Ionic radionuclides strontium-90 $\left({ }^{90} \mathrm{Sr}\right),{ }^{137} \mathrm{Cs},{ }^{152} \mathrm{Eu},{ }^{154} \mathrm{Eu}$, and plutonium-239 $\left({ }^{239} \mathrm{Pu}\right)$, although found at the sampling locations, are not readily transported outside of the cavity or chimney to the surrounding environment unless sorbed to colloids.

- Because of its higher hydraulic gradients, Pahute Mesa has a higher potential for lateral migration of radionuclides in groundwater than Yucca Flat or Frenchman Flat.

- Time-series analyses of radionuclide concentration data provide information on processes that control radionuclide migration in groundwater, which include dilution, dispersion, leaching, and precipitation.

- Plutonium and other relatively insoluble radionuclides may be transported at ambient groundwater velocities through sorption to clay and zeolite colloids suspended in fractured rock aquifers.

- Soluble species may ascend to more transmissive aquifers due to the residual heat from underground nuclear tests while other tests remain isolated for decades after the detonation.

- Radionuclides may be mobilized by prompt processes along specific and narrow passages related to rock strength and geologic structure. Volatile radionuclides may migrate to shallower intervals of the nuclear chimney through gas phase transport (Smith, 2002).

Based on the findings of this study, analytical results from cavity water samples provide useful information for hydrologic source term modeling. However, with only three sampling locations, translating the information to a larger area poses significant challenges.

\subsubsection{Radionuclide Distribution Outside the Cavity Region}

Nimz and Thompson (1992) present data and analyses to support the hypothesis of prompt fracture injection as a mechanism to transport radionuclides some distance away from an underground test cavity. On the basis of data from samples collected from several locations in Yucca Flat (i.e., U-3cn\#5, UE-4g\#2, U-9 ITS $\mathrm{U}-29, \mathrm{U}-3 \mathrm{kz}$, and UE-2ce) the transport of radionuclides over distances of 60 to perhaps $300 \mathrm{~m}$ may be attributable to prompt fracture injection. The Nimz and Thompson (1992) report also includes an interpretation of earlier data from Thompson and Gilmore (1991) that showed radionuclides had migrated a distance of $350 \mathrm{~m}$ from an underground test through volcanic tuff. 
Smith et al. (1996) suggest late time gaseous transport may also contribute to rapid migration of some radionuclides a short distance away from the cavities based on analyses from near the INGOT test in Yucca Flat.

Rose et al. (2000a) used secondary ion mass spectrometry to analyze geologic samples from the near field of the BULLION and TYBO tests. The results show correlated ${ }^{22} \mathrm{Na}$ and ${ }^{235} \mathrm{U}$ enrichments in the vadose zone at a distance of several hundred meters from the working point of the BULLION test. These results were interpreted as evidence for prompt injection.

These studies suggest that the initial distribution of radionuclides may extend beyond the edge of the cavity perhaps as much as several hundred meters.

\subsubsection{Closed System Behavior}

Rose et al. (2000b) conducted an evaluation of environmentally-closed nuclear test cavity-chimney systems. Direct measurements of anomalous chemical and temperature data at ALMENDRO and CAMEMBERT indicate that closed-system behavior is occurring in those cavities. The authors noted that both of these tests had relatively high announced yields $(>200 \mathrm{kt})$. This led them to evaluate the geologic conditions beneath Pahute Mesa to investigate whether unique conditions existed that led to the closed-system behavior. They concluded that low permeability conditions were the most likely cause of the observed closed system behavior. This finding was used to make predictions for other tests that may exhibit similar closed-system behavior (Pawloski, 2004).

\subsection{CAMBRIC Hydrologic Source Term}

In support of the Frenchman Flat CAU model, Tompson, et al. (1999) developed a process model of the unclassified CAMBRIC hydrologic source term. The objective of this model was to provide a modeling framework to quantitatively forecast the hydrologic source term within the near-field environment of an underground nuclear test (Tompson et al., 1999).

The radionuclides tritium, ${ }^{90} \mathrm{Sr},{ }^{137} \mathrm{Cs},{ }^{155} \mathrm{Eu},{ }^{239} \mathrm{Pu}$, and americium-241 $\left({ }^{241} \mathrm{Am}\right)$ were selected for the CAMBRIC source-term modeling because their inventories are unclassified (for this test) and available. These radionuclides have a varied initial distribution in the melt glass, chimney, and cavity areas, and they represent a cross-section of geochemical behavior in the subsurface environment.

The source-term model incorporates available information on the distribution and release of radionuclides. Radionuclides are partitioned among the melt glass, rubble zone, and water. The model assumes that essentially the entire inventory of potential radioactive contaminants in the rubble zone is available for leaching or dissolution and subsequent transport. The model also assumes the tritium inventory in the form of tritiated water is available for transport. A melt glass dissolution model is included to predict the release of potential contaminants from 
the melt glass. Geochemical reactions (e.g., aqueous and surface complexation, ion exchange, and precipitation/dissolution) are modeled to assess the influence of these reactions on release rates (Tompson et al., 1999).

\subsection{Simplified Frenchman Flat Hydrologic Source Term}

Tompson et al. (2004) developed an unclassified simplification of the hydrologic source term of the 10 underground nuclear tests conducted in Frenchman Flat. This simplified HST was developed from the results of the CAMBRIC HST previously described in this section, and the CHESHIRE HST discussed in the next subsection.

The basic elements of the simplified hydrologic source term model are as follows:

- Estimated volume of geologic material physically affected by the tests

- Identities, quantities, and distribution of the radionuclides of importance

- Description of simplified models of the release and retardation of these radionuclides in groundwater

As stated by Tompson et al. (2004), the HST of a specific underground test represents the flux of test-related radionuclides into groundwater, away from the underground testing point. The HST is a function of the following:

- Radionuclide inventory

- Spatial distribution of the radionuclide inventory around the test's working point

- Fractionation of the radionuclide inventory between melt glass and non-melt glass zones

- Melt glass or other material dissolution or solubility

- Rate of groundwater flow through the subsurface zones initially contaminated by the nuclear test

- Chemical mobility of the radionuclide inventory in groundwater

- Decay characteristics of the radionuclide inventory

Many of these characteristics can be estimated from the yield, depth of burial, and knowledge of the unclassified radionuclide inventories. Only unclassified information on test yields and the total Frenchman Flat radionuclide inventory were presented in this report. 
Principal assumptions include the following:

- Temperature is fixed (the impacts of residual test-related heat are not considered)

- Groundwater flow is in steady-state

- Groundwater $\mathrm{pH}$ is constant

- Radionuclide release from the melt glass occurs at a fixed rate

- Chemical sorption (via ion exchange and surface complexation) is assumed to be described by simple retardation coefficients that are functions of the geologic medium and ambient groundwater chemistry

- Radionuclide mineral precipitation/dissolution and formation of radionuclide-sorbing minerals in the melt glass elsewhere is ignored

The results of the simplified HST were compared to those of the CAMBRIC HST. The report acknowledges that the comparison was difficult because of several errors found in the CAMBRIC simulations and the limited understanding of the nature of the long-term simulated flux profiles. Based on the various examples of the simplified source term presented, it is concluded that the simplified HST appears to provide reasonable results for the conditions under which it was derived. For example, the predicted release of ${ }^{241} \mathrm{Am}$ from the CAMBRIC test using the simplified HST model compare well with the results of the CAMBRIC HST model (Tompson et al., 1999).

\subsection{CHESHIRE Hydrologic Source Term Model}

Pawloski et al. (2002) conducted an evaluation of the hydrologic source term of CHESHIRE as part of the data analysis activities for the Pahute Mesa CAUs. A summary of this analysis is presented including the purpose, approach, results and major conclusions.

The purpose of the analysis conducted by Pawloski et al. (2002) was to develop a basic understanding of how radionuclides move from the radiologic source term of underground nuclear tests into groundwater. As stated by Pawloski et al. (2002), the objectives were "to develop, summarize, and interpret a series of detailed unclassified simulations that forecast the nature and extent of radionuclide release and near-field migration in groundwater away from the CHESHIRE test over the next 1,000 years. Collectively, these results are called the CHESHIRE Hydrologic Source Term."

The approach included the development of a conceptual model of the near-field environment, a groundwater flow model, geochemical models, reactive transport models of radionuclides. The models were used to simulate radionuclide release into groundwater and migration away from the near field of the CHESHIRE test on Pahute Mesa. The approach included the following three tasks: 
- Estimate the abundance, spatial distribution, and chemical state of radionuclide contamination just after the test.

- Determine the mechanisms and rates of radionuclide release into the groundwater as a function of time.

- Forecast the rates of radionuclide movement away from the working point of the test for a 1,000-year period, as affected by groundwater flow and chemical reactions.

A conceptual model of the CHESHIRE near-field environment was developed using the maximum value of the announced yield range. This conceptual model includes a cavity ( $80-\mathrm{m}$ radius), the melt glass mass ( $3.5 \times 10^{5}$ metric tons), and a disturbed zone (128-m radius). The collapse zone is known to extend above the water table but not to the ground surface. The unclassified residual inventory is equal to the mean value of the unclassified radionuclide inventory for the 76 tests conducted below or near the water table in Areas 19 and 20 (Smith, 2001). Therefore, initial inventory is $1 / 76$ of the values in Smith (2001).

Pawloski et al. (2002) used the summed unclassified radionuclide inventory for saturated tests on Pahute Mesa which was averaged and applied at the CHESHIRE site. They used summed unclassified inventory data reported by Smith (2001) because the data reported by Bowen et al. (2001) were not available at the time.

The CHESHIRE model list of radionuclides was derived from three sources: a report on the unclassified radiologic source term (Smith, 2001), recommendations by the UGTA Source Term Subcommittee (Smith, 1997), and a set of reports containing radionuclide measurements in groundwater near CHESHIRE (Finkel et al., 1992; Daniels et al., 1993; Smith et al., 1998, 1999, and 2000; and Thompson, 2000). A total of 52 radionuclides were identified from these three sources of information. They include the 43 nuclides listed in Table 3-7. Five additional nuclides (Cobalt-60 [ $\left.{ }^{60} \mathrm{Co}\right]$, Ruthenium-106 [ $\left.{ }^{106} \mathrm{Ru}\right]$, Antimony-125 $\left[{ }^{125} \mathrm{Sb}\right],{ }^{134} \mathrm{Cs}$, and ${ }^{155} \mathrm{Eu}$ ) were obtained from the UGTA committee recommendations. Three additional nuclides (Sodium-22 [ $\left.{ }^{22} \mathrm{Na}\right]$, Manganese-54 $\left[{ }^{54} \mathrm{Mn}\right]$, and Cerium-144 $\left.\left[{ }^{144} \mathrm{Ce}\right]\right)$ were added based on the CHESHIRE radionuclide data.

Thirty seven out the 52 radionuclides were selected for incorporation into the unclassified CHESHIRE HST model (Table 3-7). Radionuclides were excluded from consideration either: (1) because they had no inventory or (2) they did not satisfy criteria related to their abundance (Pawloski et al., 2002). Abundance criteria are as follows:

1. The radionuclide must have a reported test-related inventory, as defined by the data in Smith (2001), and this inventory must equal or exceed any corresponding natural inventory in the rock.

2. For all alpha, beta, or electron capture/isomeric transition decay radionuclides, the ratio of the radionuclide's activity (in Becquerel [Bq]) or amount (in moles) to the activity or amount for all alpha, beta, or 
electron capture/isomeric transition radionuclides exceeds a value of 0.1 percent of the total, at some time during the 1,000-year period of interest.

3. The radionuclide has a reported concentration in groundwater taken from the CHESHIRE cavity, chimney, or near the CHESHIRE test.

The radiologic source term was either partitioned into the melt glass or distributed throughout an approximate spherical exchange volume surrounding the cavity and disturbed zone extending into portions of the chimney (Table 3-7). To reduce the number of transport simulations, the radionuclides were segregated into 13 groups based on similarities in partitioning and chemical reactivity characteristics.

The CHESHIRE flow model was based on the NUFT (Nonisothermal Unsaturated-Saturated Flow and Transport Model) code (Nitao, 1988 and 1989). NUFT is a computer model that solves the continuum balance equations for the conservation of mass, momentum, and thermal energy. The flow model was designed to account for the influence of test-related and geothermal heat. Model results indicated a strong tendency for rapid upward and dynamic movement of groundwater (mobile radionuclides) away from the cavity area for a period lasting several decades. Several models were evaluated; however, the geostatistically heterogeneous model was able to reproduce all measured temperature profiles and observed tracer pathways (Pawloski et al., 2002).

Mechanistic models were used to describe the geochemical interactions controlling the radionuclide release from the melt glass and the exchange volume, as well as the radionuclide-rock interactions along the flow path. These models were designed to simulate kinetically-controlled melt glass dissolution and radionuclide precipitation and equilibrium-controlled aqueous speciation, surface complexation, and ion exchange. To address the uncertainty in sorption related to natural mineral variability, the spatial distribution of reactive minerals in the fractured tuff was determined using geostatistical procedures. The resulting distributions were incorporated into the transport models.

Two models were used to simulate the transport of radionucludes in groundwater. A reactive streamline model and a more efficient particle-based model were used to develop reactive transport simulations of radionuclide migration away from the CHESHIRE cavity and melt glass region. The efficient particle-based model was used to handle the strong transient flow fields common during the first 100 years of a typical CHESHIRE flow simulation. The particle models were run for the first 100 years and provided the starting point for the streamline calculations.

Pawloski et al. (2002) identified several issues that need to be addressed when using the results of the CHESHIRE HST model in larger-scale radionuclide transport models. These issues are as follows:

- Flow rates used in the CHESHIRE HST model may be different from those used in larger-scale models. Thus, scaling of the CHESHIRE HST results may be required. 
Table 3-7

Radionuclides Used in the CHESHIRE Hydrologic Source Term Model

(Page 1 of 2)

\begin{tabular}{|c|c|c|c|c|c|c|c|c|c|c|}
\hline \multirow{2}{*}{ Isotope } & \multirow{2}{*}{$\begin{array}{l}\text { Half-life } \\
\text { (Years) }\end{array}$} & \multicolumn{2}{|c|}{ Reported Average Inventory } & \multicolumn{4}{|c|}{$\begin{array}{c}\text { Distribution } \\
\text { (Percent) }\end{array}$} & \multicolumn{3}{|c|}{ Initial Distribution } \\
\hline & & $\begin{array}{c}\text { Activity } \\
\text { (Bq) }\end{array}$ & $\begin{array}{c}\text { Amount } \\
\text { (Mole) }\end{array}$ & $\operatorname{Lava}^{a}$ & Rubble & Gas & Water & $\begin{array}{c}\text { Melt glass } \\
\text { (Mole/Gram) }\end{array}$ & $\begin{array}{l}\text { Cavity/Exchange } \\
\text { Volume Water, } \\
\text { (Mole/Liter) }\end{array}$ & $\begin{array}{l}\text { Melt Glass Water } \\
\text { (Mole/Liter) }\end{array}$ \\
\hline Tritium & $1.23 \times 10^{1}$ & $3.40 \times 10^{16}$ & $3.16 \times 10^{1}$ & 0 & 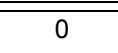 & 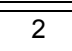 & 98 & 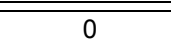 & $6.95 \times 10^{-8}$ & $6.95 \times 10^{-8}$ \\
\hline Carbon-14 & $5.730 \times 10^{3}$ & $2.70 \times 10^{11}$ & $1.17 \times 10^{-1}$ & 0 & 10 & 80 & 10 & 0 & $2.60 \times 10^{-10}$ & $2.32 \times 10^{-10}$ \\
\hline Chlorine-36 & $3.01 \times 10^{5}$ & $1.04 \times 10^{11}$ & 2.37 & 50 & 40 & 0 & 10 & $3.39 \times 10^{-12}$ & $2.81 \times 10^{-9}$ & $5.21 \times 10^{-10}$ \\
\hline Argon-39 & $2.69 \times 10^{2}$ & $8.99 \times 10^{11}$ & $1.83 \times 10^{-2}$ & 0 & 10 & 80 & 10 & 0 & $4.06 \times 10^{-11}$ & $3.62 \times 10^{-11}$ \\
\hline Calcium-41 & $1.03 \times 10^{5}$ & $7.99 \times 10^{11}$ & 6.22 & 70 & 30 & 0 & 0 & $1.24 \times 10^{-11}$ & $4.51 \times 10^{-9}$ & 0 \\
\hline Nickel-59 & $7.6 \times 10^{4}$ & $1.94 \times 10^{10}$ & $1.12 \times 10^{-1}$ & 95 & 5 & 0 & 0 & $3.04 \times 10^{-13}$ & $1.35 \times 10^{-11}$ & 0 \\
\hline Nickel-63 & $1.00 \times 10^{2}$ & $2.05 \times 10^{12}$ & $1.55 \times 10^{-2}$ & 95 & 5 & 0 & 0 & $4.21 \times 10^{-14}$ & $1.87 \times 10^{-12}$ & 0 \\
\hline Krypton-85 & $1.073 \times 10^{1}$ & $4.66 \times 10^{13}$ & $3.78 \times 10^{-2}$ & 0 & 10 & 80 & 10 & 0 & $8.39 \times 10^{-11}$ & $7.48 \times 10^{-11}$ \\
\hline Strontium-90 & $2.91 \times 10^{1}$ & $5.81 \times 10^{14}$ & 1.28 & 40 & 60 & 0 & 0 & $1.46 \times 10^{-12}$ & $1.86 \times 10^{-9}$ & 0 \\
\hline Zirconium-93 & $1.5 \times 10^{6}$ & $2.03 \times 10^{10}$ & 2.3 & 95 & 5 & 0 & 0 & $6.24 \times 10^{-12}$ & $2.78 \times 10^{-10}$ & 0 \\
\hline Niobium-93m & $1.61 \times 10^{1}$ & $3.70 \times 10^{12}$ & $4.50 \times 10^{-3}$ & 95 & 5 & 0 & 0 & $1.22 \times 10^{-14}$ & $5.44 \times 10^{-13}$ & 0 \\
\hline Niobium-94 & $2.0 \times 10^{4}$ & $8.44 \times 10^{10}$ & $1.27 \times 10^{-1}$ & 95 & 5 & 0 & 0 & $3.45 \times 10^{-13}$ & $1.53 \times 10^{-11}$ & 0 \\
\hline Technetium-99 & $2.13 \times 10^{5}$ & $1.49 \times 10^{11}$ & 2.41 & 80 & 20 & 0 & 0 & $5.51 \times 10^{-12}$ & $1.16 \times 10^{-9}$ & 0 \\
\hline Palladium-107 & $6.5 \times 10^{6}$ & $7.66 \times 10^{8}$ & $3.76 \times 10^{-1}$ & 70 & 30 & 0 & 0 & $7.52 \times 10^{-13}$ & $2.73 \times 10^{-10}$ & 0 \\
\hline Tin-121m & $\sim 5.5 \times 10^{1}$ & $2.10 \times 10^{12}$ & $8.72 \times 10^{-3}$ & 60 & 40 & 0 & 0 & $1.49 \times 10^{-14}$ & $8.43 \times 10^{-12}$ & 0 \\
\hline Tin-126 & $\sim 1 \times 10^{5}$ & $2.39 \times 10^{10}$ & $1.81 \times 10^{-1}$ & 70 & 30 & 0 & 0 & $3.62 \times 10^{-13}$ & $1.31 \times 10^{-10}$ & 0 \\
\hline lodine-129 & $1.57 \times 10^{7}$ & $4.59 \times 10^{8}$ & $5.44 \times 10^{-1}$ & 50 & 40 & 0 & 10 & $7.77 \times 10^{-13}$ & $6.45 \times 10^{-10}$ & $1.20 \times 10^{-10}$ \\
\hline Cesium-135 & $2.3 \times 10^{6}$ & $1.54 \times 10^{10}$ & 2.68 & 20 & 80 & 0 & 0 & $1.53 \times 10^{-12}$ & $5.18 \times 10^{-9}$ & 0 \\
\hline Cesium-137 & $3.017 \times 10^{1}$ & $7.36 \times 10^{14}$ & 1.68 & 20 & 80 & 0 & 0 & $9.60 \times 10^{-13}$ & $3.25 \times 10^{-9}$ & 0 \\
\hline Samarium-151 & $9.0 \times 10^{1}$ & $2.78 \times 10^{13}$ & $1.89 \times 10^{-1}$ & 95 & 5 & 0 & 0 & $5.13 \times 10^{-13}$ & $2.28 \times 10^{-11}$ & 0 \\
\hline Europium-150 & $3.6 \times 10^{1}$ & $5.40 \times 10^{11}$ & $1.47 \times 10^{-3}$ & 95 & 5 & 0 & 0 & $2.79 \times 10^{-15}$ & $1.24 \times 10^{-13}$ & 0 \\
\hline Europium-152 & $1.348 \times 10^{1}$ & $1.60 \times 10^{13}$ & $1.63 \times 10^{-2}$ & 95 & 5 & 0 & 0 & $4.42 \times 10^{-14}$ & $1.97 \times 10^{-12}$ & 0 \\
\hline Europium-154 & 8.59 & $7.55 \times 10^{12}$ & $4.90 \times 10^{-3}$ & 95 & 5 & 0 & 0 & $1.33 \times 10^{-14}$ & $5.92 \times 10^{-13}$ & 0 \\
\hline Holmium-166m & $1.2 \times 10^{3}$ & $2.18 \times 10^{10}$ & $1.98 \times 10^{-3}$ & 95 & 5 & 0 & 0 & $5.37 \times 10^{-15}$ & $2.39 \times 10^{-13}$ & 0 \\
\hline
\end{tabular}


Table 3-7

Radionuclides Used in the CHESHIRE Hydrologic Source Term Model

(Page 2 of 2)

\begin{tabular}{|c|c|c|c|c|c|c|c|c|c|c|}
\hline \multirow{2}{*}{ Isotope } & \multirow{2}{*}{$\begin{array}{l}\text { Half-life } \\
\text { (Years) }\end{array}$} & \multicolumn{2}{|c|}{ Reported Average Inventory } & \multicolumn{4}{|c|}{$\begin{array}{c}\text { Distribution } \\
\text { (Percent) }\end{array}$} & \multicolumn{3}{|c|}{ Initial Distribution } \\
\hline & & $\begin{array}{l}\text { Activity } \\
\text { (Bq) }\end{array}$ & $\begin{array}{c}\text { Amount } \\
\text { (Mole) }\end{array}$ & Lava $^{a}$ & Rubble & Gas & Water & $\begin{array}{c}\text { Melt glass } \\
\text { (Mole/Gram) }\end{array}$ & $\begin{array}{l}\text { Cavity/Exchange } \\
\text { Volume Water, } \\
\text { (Mole/Liter) }\end{array}$ & $\begin{array}{l}\text { Melt Glass Water } \\
\text { (Mole/Liter) }\end{array}$ \\
\hline Uranium-232 & $7.0 \times 10^{1}$ & $1.24 \times 10^{11}$ & $6.57 \times 10^{-4}$ & 90 & 10 & 0 & 0 & $1.69 \times 10^{-15}$ & $1.59 \times 10^{-13}$ & 0 \\
\hline Uranium-233 & $1.592 \times 10^{5}$ & $8.33 \times 10^{10}$ & 1 & 90 & 10 & 0 & 0 & $2.57 \times 10^{-12}$ & $2.42 \times 10^{-10}$ & 0 \\
\hline Uranium-234 & $2.46 \times 10^{5}$ & $5.99 \times 10^{10}$ & 1.11 & 90 & 10 & 0 & 0 & $2.85 \times 10^{-12}$ & $2.68 \times 10^{-10}$ & 0 \\
\hline Uranium-235 & $7.04 \times 10^{8}$ & $8.07 \times 10^{8}$ & $4.29 \times 10^{1}$ & 90 & 10 & 0 & 0 & $1.10 \times 10^{-10}$ & $1.04 \times 10^{-8}$ & 0 \\
\hline Uranium-236 & $2.342 \times 10^{7}$ & $2.30 \times 10^{9}$ & 4.07 & 90 & 10 & 0 & 0 & $1.05 \times 10^{-11}$ & $9.83 \times 10^{-10}$ & 0 \\
\hline Uranium-238 & $4.47 \times 10^{9}$ & $1.07 \times 10^{9}$ & $3.60 \times 10^{2}$ & 90 & 10 & 0 & 0 & $9.26 \times 10^{-10}$ & $8.70 \times 10^{-8}$ & 0 \\
\hline Neptunium-237 & $2.14 \times 10^{6}$ & $1.78 \times 10^{10}$ & 2.87 & 95 & 5 & 0 & 0 & $7.79 \times 10^{-12}$ & $3.47 \times 10^{-10}$ & 0 \\
\hline Plutonium-238 & $8.77 \times 10^{1}$ & $3.49 \times 10^{12}$ & $2.31 \times 10^{-2}$ & 95 & 5 & 0 & 0 & $6.27 \times 10^{-14}$ & $2.79 \times 10^{-12}$ & 0 \\
\hline Plutonium-239 & $2.410 \times 10^{4}$ & $9.40 \times 10^{12}$ & $1.71 \times 10^{1}$ & 95 & 5 & 0 & 0 & $4.64 \times 10^{-11}$ & $2.07 \times 10^{-9}$ & 0 \\
\hline Plutonium-240 & $6.56 \times 10^{3}$ & $3.02 \times 10^{12}$ & 1.5 & 95 & 5 & 0 & 0 & $4.07 \times 10^{-12}$ & $1.81 \times 10^{-10}$ & 0 \\
\hline Plutonium-241 & $1.44 \times 10^{1}$ & $4.37 \times 10^{13}$ & $4.75 \times 10^{-2}$ & 95 & 5 & 0 & 0 & $1.29 \times 10^{-13}$ & $5.74 \times 10^{-12}$ & 0 \\
\hline Americium-241 & $4.327 \times 10^{2}$ & $2.27 \times 10^{12}$ & $7.43 \times 10^{-2}$ & 95 & 5 & 0 & 0 & $2.02 \times 10^{-13}$ & $8.98 \times 10^{-12}$ & 0 \\
\hline Curium-244 & $1.81 \times 10^{1}$ & $1.45 \times 10^{12}$ & $1.98 \times 10^{-3}$ & 95 & 5 & 0 & 0 & $5.37 \times 10^{-15}$ & $2.39 \times 10^{-13}$ & 0 \\
\hline
\end{tabular}

Source: Adapted from Pawloski et al. (2002)

$\mathrm{Bq}=$ Becquerel

aln this report the term "melt glass" is synonomous with "Lava." 
- The dispersion of radionuclides is computed directly in the CHESHIRE HST model via a random-field approach. In this case, the heterogeneous material properties are included directly in the model which leads to a heterogeneous velocity field that produces dispersion. The computed dispersion is dependent of the scale of the model, thus these computed dispersion values should not be used directly in the larger-scale models where the dispersive effects should be specified in terms of macrodispersivities.

- The retardation properties are also directly calculated in the CHESHIRE HST model. These computed values should be used directly in the larger-scale models.

The main conclusions of the analysis conducted by Pawloski et al. (2002) were as follows:

- The release of radionuclides from the melt glass, although proportional to temperature, is generally slow and long-lasting, regardless of their retardation characteristics in the geologic medium.

- The release of radionuclides from the exchange volume is generally quicker and more short-lived, although significant radionuclide retention in the near field occurs for the more sorptive radionuclides.

- The flux of radionuclides past the UE-20n\#1 control plane is affected by heterogeneity in the physical and reactive properties of the geologic medium.

- The fluxes of several short-lived radionuclides past the UE-20n\#1 control plane decrease to a relatively insignificant level within 400 years from the test date.

\subsection{Uncertainties in HST Definition}

Uncertainties associated with the definition of the hydrologic source term have been evaluated by Smith et al. (1995).

The HST may be estimated from measurements of radionuclide activities observed in the cavity water, or it may be derived from the radiologic source term. According to Smith et al. (1995), its definition is complicated by a number of factors. The main factors are as follows:

- Samples of cavity water are affected by drilling and completion activities.

- Radionuclides with half-lives shorter than 10 years are not accounted for in the radiologic source term radionuclide inventory. 
- The transfer of radionuclides from the source term to the hydrologic source term involves the processes of leaching and sorption. The relative importance of these two processes is not well understood.

- Little information exists on the factors affecting melt glass leaching. These factors include melt glass composition, its initial distribution of radionuclides, its available surface area, the leachate's chemistry, and the cavity's temperature.

- Information on the geochemical controls of radionuclide sorption is lacking. Geochemical controls include groundwater composition; the specific radionuclide in solution and its oxidation state; the fluid temperature; and the abundance, composition, cation exchange capacity of the minerals present.

- Much more information on fracture systematics near test cavities is required. In addition, matrix diffusion coefficients are not available for all NTS lithologies.

- Extent of colloid loading in NTS is unknown. Colloid loading observed in well samples are affected by the well construction, its development, and groundwater production during sampling.

- For 100 to 200 years, tritium in or near the saturated zone has the highest activity of any radionuclide with a half life greater than 10 years.

- Tritium is an excellent measure of both the radiologic and hydrologic source terms.

The report concludes that knowledge necessary to define the hydrologic source term for fission and activation products is unavailable.

\subsection{TYBO-BENHAM Model}

Wolfsberg et al. (2002) conducted a modeling study to investigate the migration of radionuclides in the TYBO-BENHAM local groundwater system.

The purpose of this study was to develop a modeling framework to evaluate the processes and mechanisms that control radionuclide migration in Pahute Mesa groundwater. Specific objectives included tracing quantities of plutonium at TYBO observation wells that originated from BENHAM (Kersting et al., 1998), and providing a defensible predictive tool for other Pahute Mesa modeling needs.

A three-component approach was developed that integrates a sub-CAU flow model, source-term models, and site-scale transport models into a predictive framework. Modeling simulations were conducted that:

- Provide estimates of aquifer properties and flow solutions that match head observations 
- Predict radionuclide releases from cavity/chimney systems incorporating processes of melt glass dissolution and thermal convection

- Predict radionuclide concentrations consistent with field observations

- Provide sensitivity analysis for uncertain parameters

The sub-CAU Flow Model provides hydrologic control on the sub-CAU-scale domain while determining aquifer, aquitard, and fault-zone permeabilities needed to match head observations in boreholes. The Boxcar Fault is included to create a steep hydrologic gradient within the study domain. Low permeability aquitards preserve both an upward gradient from a deep, high-pressure unit and a downward gradient in the shallow units near the water table. The flow domain contains aquifer and aquitard properties that were estimated for HSUs in which no head measurements exist, because the model is incompletely constrained by the limited data. Greater confidence in results could be obtained if a larger domain with more head observations were modeled; however, the existing model reasonably predicts observations within the domain, highlights problems associated with fault zone hydraulics and provides reasonable boundary conditions for the CAU-scale models.

Two source-term models were developed, the thermal-hydrologic-chemical (THC) transport model and a 3-D source-term model, that compliment each other in predicting source releases to the site-scale domain. A two-dimensional, fully coupled, THC transport model predicts the rate of melt glass dissolution changes during the dynamic cooling process within the cavity-chimney system. Because melt glass dissolution controls the release of radionuclides into solution, the model accentuates the importance of modeling the early time processes that occur during cavity/chimney rewetting where dissolution rates will be extremely significant. A 3-D source-term model simulates the transient thermal flow and cooling processes in the cavity-chimney system and couples particle release in the melt glass to the temperature-dependent dissolution processes identified in the THC model.

Site-scale transport modeling is performed with process and abstraction models. The process model identifies the key processes and relationships while the abstraction model performs parameter sensitivity.

The first of the process models was designed to simulate the results of laboratory column experiments. The model is a dual-porosity transport model incorporating plutonium speciation, reactions with solutes and minerals, and reactions with colloids as well as colloid filtration. This model was extended to a larger domain (Benham site scale) by simulating reactive transport along streamtubes using the Generalized Dual-Porosity Model (GDPM) to represent fracture-matrix interactions. Transport simulations were conducted for 14 radionuclides in a 3-D heterogeneous site-scale model. The field-scale process model is abstracted to a more efficient simulator that utilizes dual-porosity reactive particle-tracking transport and convolution integrals to generate unit source-term breakthrough curves at the ER-20-5 observations wells and the NTS boundary. Because of its efficiency, the abstraction model is used in parameter sensitivity analysis. 
This site-scale reactive process model demonstrates that, with expected parameter values, migration of very low quantities of plutonium from BENHAM to the ER-20-5 observation wells can occur in less than 30 years if a continuous fractured aquifer exists. However, the pathways from the BENHAM chimney to ER-20-5\#1 encounter welded tuff, non-welded tuff, and bedded tuff that are not fractured. Along such pathways, rapid migration does not occur because (1) the velocities are lower in matrix-flow material and (2) retardation via matrix sorption is increased causing plutonium to desorb from the colloids and sorb onto immobile minerals when expected values for Pu-colloids desorption rates are used. Non-reactive radionuclides with the exception of tritium, which decays over time, all show substantial mobility with time. The sensitivity study also shows substantial variation with respect to Eh, colloid concentration and available reactive surface of fracture minerals.

Using expected values for parameters and the deterministic property model, simulated travel times and groundwater concentrations are consistent with the field observations for all radionuclides found in both ER-20-5 wells. The use of expected values for parameters and one of thirty heterogeneous property model results in prolonged travel times to ER-20-5\#1, because transport pathways leaving the BENHAM chimney at the upper release location encounter welded tuff, bedded tuff, and nonwelded tuff. The particle tracking results are consistent with the field observations (Kersting et al., 1998) in well ER-20-5\#3 in the lava formation and consistent with the results from the process level reactive transport model, with one exception. When expected values are used for transport parameters in the particle tracking model, $\mathrm{Pu}$-colloid is predicted to arrive at ER-20-5\#1 well beyond 30 years.

A detailed set of parameter sensitivity studies were conducted with the site-scale transport model. Key uncertainty parameters to which results are most sensitive include fracture porosity, matrix $\mathrm{K}_{\mathrm{d}}$, and the source term function. 


\section{Source Term Process Model Simplifications}

This section presents a description of an unclassified Simplified Source Term Model (SSM) developed to estimate radionuclide source inputs for the Pahute Mesa CAU model. More specifically, this section describes the development and testing of a SSM to represent the near-field source term releases from the CHESHIRE test. The development of this SSM is based on the detailed process model in Evaluation of the Hydrologic Source Term from Underground Nuclear Tests on Pahute Mesa at the Nevada Test Site: The CHESHIRE Test

(Pawloski et al., 2002).

\subsection{Simplified Source Term Model}

As presented in Section 3.0, source term process models simulate the thermal, hydrological, and chemical processes that govern the migration of radionuclides from underground test cavities through an aquifer system. These multi-dimensional process models have the potential to simulate radionuclide release from a specific underground test, assuming that adequate site-specific data are available to support classified simulations. The disadvantage of the process model approach is the large amount of information required and the time-consuming process of performing multiple simulations to explore the potential range of releases from a given test. Given these limitations, it is impractical to use the process models to perform source calculations for all the underground tests on Pahute Mesa. Therefore, a simpler source term model, called the SSM, was developed using the GoldSim ${ }^{\circledR}$ platform (Golder, 2002a and $2002 b$ ) to generate cavity source flux terms for use in the CAU-scale radionuclide transport model of the PM area. A brief description of the GoldSim ${ }^{\circledR}$ platform is provided in Appendix B.

The objective of the SSM is to provide an unclassified tool that captures the important processes and uncertainties of the source term in an efficient computational methodology. As such, the SSM is an alternate computational technique that provides insights into the range of potential radionuclide releases from individual underground tests. The SSM is not independent of the multi-dimensional process-level models because it is guided and calibrated by the results from the process-level models. In effect, the SSM is a parallel computational technique that can provide useful insights into the important processes and potential variability of source term release.

The initial step in developing the SSM for PM source term evaluations has been the development of an SSM that simulates the process level source term for the CHESHIRE test (Pawloski et al., 2002). The SSM for CHESHIRE captures the 
important hydrological and chemical processes in such a way that the range of output fluxes from the SSM will represent the range of fluxes from the detailed source model. The major stochastic parameters in the SSM are the groundwater flux through the exchange volume, the groundwater flux through the melt glass, the retardation ratios in the near-field fracture linings, and the retardation ratios in the chimney and cavity. These random parameters directly mirror the geostatistical representations of near-field permeability and near-field geochemistry in the process level CHESHIRE model (Pawloski et al., 2002).

While the unclassified yield of the CHESHIRE test is reported within a range (200 to 500 kilotons), a constant value of 500 kilotons is the basis for the process-level CHESHIRE model and the SSM. Similarly, the SSM has constant values for the radionuclide inventory, source parameters (i.e., volume, mass porosity), and for the partitioning of inventory between the source volumes that mirror the approach in the process-level CHESHIRE model. Future modifications to the SSM may incorporate variability in these parameters for calculations of other underground tests on Pahute Mesa.

\subsubsection{Components of the Simplified Source Term Model}

The SSM for CHESHIRE is comprised of a source region plus a small section of the surrounding near-field rock where the initial transport and mixing of waters flowing out of the source region takes place. The source region is divided into two subregions: (1) the cavity which includes the puddle of melt glass that forms at the bottom of the cavity and unconsolidated rubble from the collapsed chimney and disturbed zone and (2) the surrounding disturbed zone. The disturbed zone is further divided into "intact" rock that has had additional fracturing from the test but is not rubblized, and the rubblized rock in the collapsed chimney directly above the cavity. Figure 4-1 provides an illustration of these regions.

\subsubsection{Dimensions of the Source Regions}

For the SSM, the source is represented as two volumes: the puddle of melt glass and the exchange volume. The exchange volume consists of the cavity zone (i.e., the cavity excluding the melt glass) and the disturbed zone immediately surrounding the cavity.

The radii of the cavity and the disturbed zone are often determined as a function of yield. A standard equation relating yield and cavity radius is given by Pawloski (1999):

$$
R_{c}=\frac{70.2(Y)^{1 / 3}}{\left(\rho_{b} D O B\right)^{1 / 4}}
$$

where

$R_{C} \quad=$ The cavity radius in meters

$Y=$ The yield in kilotons 


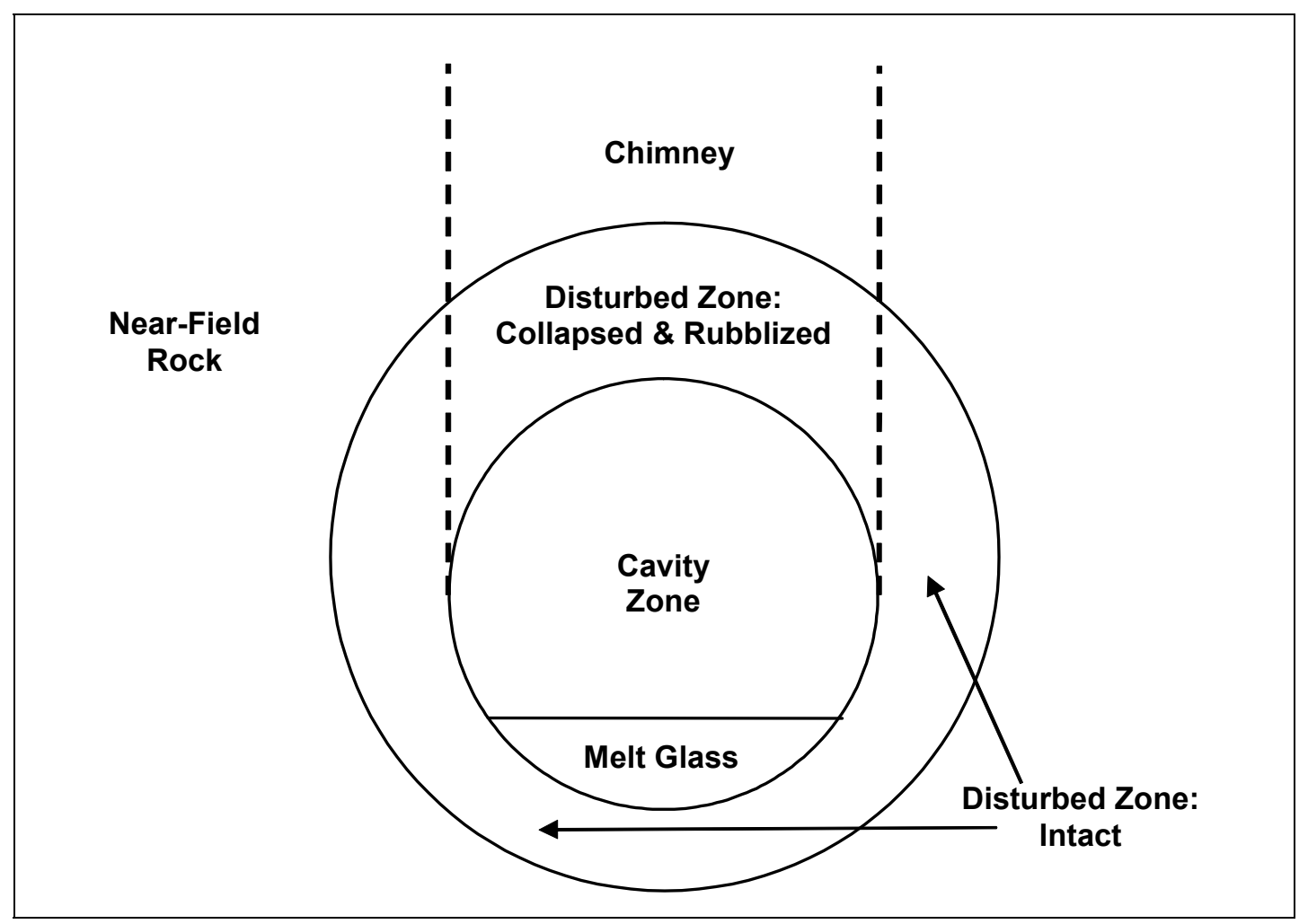

Figure 4-1

Schematic Diagram of the Source Term Regions in the CHESHIRE Process-Level Model and in the SSM.

$\rho_{b} \quad=$ The bulk density of the overlying rock and soils in grams per cubic centimeter $(\mathrm{g} / \mathrm{cc})$

$D O B=$ The depth of burial in meters.

Applying Equation (4-1) with the parameters for the CHESHIRE test (500 kilotons, $2.1 \mathrm{~g} / \mathrm{cc}$, and 1,167 meters), results in a value for $R_{C}$ of 79.19 meters. This value has been rounded up to 80 meters by Pawloski et al. (2002) for their process model, and the same constant value is used in the SSM. Similarly, Pawloski et al. (2002) assume that the radius of the disturbed zone is 60 percent greater than the radius of the cavity, or 128 meters, and the same constant value is used in the SSM. Finally, the radius of the cylindrical chimney is equal to the cavity radius, 80 meters.

The volume of the melt glass is estimated on the basis of 700 metric tons of melt glass produced per kiloton of yield. This results in a total mass of 350,000 metric tons of glass for CHESHIRE, or $3.5 \times 10^{8}$ kilograms $(\mathrm{kg})$. The volume of the melt glass is calculated, based on a density of 2,500 kilograms per cubic meter $\left(\mathrm{kg} / \mathrm{m}^{3}\right)$ and a porosity of 20 percent, as:

$$
V_{M G}=\frac{M_{M G}}{\left(1-\phi_{M G}\right) \rho_{M G}}=1.75 \times 10^{5} \mathrm{~m}^{3}
$$


The melt glass parameters are identical for the process model and for the SSM. Finally, the process model assumes that the cavity is centered 16 meters below the center of the disturbed zone. This shift affects the volumes of the intact disturbed zone and the rubblized disturbed zone, but not the cavity or the melt glass.

\subsubsection{Volumes and Porosities of the Source Regions}

Based on the information in Section 4.1.1.1, Table 4-1 lists the volumes and pore volumes of the cavity, intact disturbed zone, rubblized disturbed zone, and exchange volume for the CHESHIRE test. The pore volumes are based on constant porosity for the various regions, consistent with values defined in Table 4-2 of Pawloski et al. (2002). The pore volumes are assumed to be fully saturated. Although the test will initially vaporize any water in the cavity and possibly the disturbed zone, the pore volumes are fully saturated for the SSM because the CHESHIRE cavity is below the water table and because the cavity is anticipated to rapidly refill with groundwater.

Table 4-1

Volume, Porosity, and Pore Volume of Source Regions

\begin{tabular}{|c|c|c|c|}
\hline Region & Volume $\left.\mathbf{( m}^{3}\right)$ & Porosity (\%) & Pore Volume $\left.\mathbf{( m}^{3}\right)$ \\
\hline \hline Melt Glass & $1.75 \times 10^{5} \mathrm{~m}^{3}$ & 0.20 & $3.5 \times 10^{4} \mathrm{~m}^{3}$ \\
\hline Cavity Zone $^{\mathrm{a}}$ & $1.97 \times 10^{6} \mathrm{~m}^{3}$ & 0.10 & $1.97 \times 10^{5} \mathrm{~m}^{3}$ \\
\hline Disturbed Zone - Rubblized & $1.55 \times 10^{6} \mathrm{~m}^{3}$ & 0.10 & $1.55 \times 10^{5} \mathrm{~m}^{3}$ \\
\hline Disturbed Zone - Intact & $5.09 \times 10^{6} \mathrm{~m}^{3}$ & 0.01 & $5.09 \times 10^{4} \mathrm{~m}^{3}$ \\
\hline Exchange Volume $^{\mathrm{b}, \mathrm{c}}$ & $8.61 \times 10^{6} \mathrm{~m}^{3}$ & 0.0468 & $4.03 \times 10^{5} \mathrm{~m}^{3}$ \\
\hline
\end{tabular}

${ }^{a}$ Cavity zone is the region within the cavity, excluding the melt glass

${ }^{b}$ Exchange Volume is the sum of the cavity zone volume and the disturbed zone volumes

'Porosity of the Exchange Volume is the effective porosity of its three component parts.

The volumes and pore volumes in Table 4-1 do not exactly match the volumes in the process model for CHESHIRE (Pawloski et al. 2002, Table 4-2). The values in Table 4-1 are geometrically exact, while the values in Pawloski et al.

(2002, Table 4-2) are adjusted for the finite size (10 meters on a side) of the grid blocks in the model. The SSM uses the exact values in Table 4-1.

\subsubsection{Hydrologic Model}

Groundwater will flow through the far-field rock with a flux determined by the effective permeability and far-field hydraulic head in the formation. When the groundwater reaches the underground test region, it will flow through the exchange volume and the melt glass at different rates, depending on the hydraulic conductivity of those two regions relative to each other and the hydraulic conductivity of the unaltered host rock. The flowing groundwater removes 
radionuclides from the melt glass and exchange volume, and transports them through the near-field rock to the downgradient release boundary set at 305 meters from the center of the cavity for the CHESHIRE SSM simulations. This boundary is envisioned as the location where the SSM intersects the larger-scale model for Pahute Mesa. When applying the SSM as part of the PM source term evaluation, the distance to this boundary may be revised to reflect the mesh of the PM CAU-model.

The hydrologic process model simulates the individual regions within the cavity and disturbed zone. The permeability $(\mathrm{k})$ and porosity $(\phi)$ of the individual regions in the process model are defined in Figure 4-2 based on data in Table 5-3 of Pawloski et al. (2002). For hydrological purposes, the cavity zone is divided into an upper cavity zone and a lower cavity zone, each of which has unique physical flow properties. In addition, the permeability of the near-field rock is sampled from four distinct values: $7.2 \times 10^{-13}, 1.4 \times 10^{-14}, 2.6 \times 10^{-15}$, or $2.5 \times 10^{-16} \mathrm{~m}^{2}$. The two high-permeability values represent fracture flow with a porosity of 0.01 and the two small values of permeability represent matrix flow with a porosity of 0.15 .

The SSM represents this groundwater flow system with three basic components: the exchange volume, the melt glass, and the near-field transport pathway. It is reasonable within the context of the SSM to combine the multiple regions in the cavity and the disturbed zone into the exchange volume. First, the permeability of the cavity zones $\left(1 \times 10^{-12}\right.$ to $\left.5 \times 10^{-11} \mathrm{~m}^{2}\right)$ and the disturbed zones $\left(4 \times 10^{-12} \mathrm{~m}^{2}\right)$ lies within a reasonably narrow range. If the lower cavity zone, with a permeability of $1 \times 10^{-12} \mathrm{~m}^{2}$, is ignored because it has a relatively small volume compared to the other regions, then the range of permeability is reduced to $4 \times 10^{-12}$ to $5 \times 10^{-11} \mathrm{~m}^{2}$. Second, the range of permeability in the cavity zones and disturbed zones is greater than the permeability of the melt glass, $4 \times 10^{-14} \mathrm{~m}^{2}$, by a factor of at least 250 for the upper cavity zone and the disturbed zones. In this situation, the melt glass is a small, low-permeability kernel that is embedded within a much larger volume of higher-permeability rock that has been disturbed or rubblized by the underground test. It is then reasonable to represent the source regions as the melt glass and the exchange volume for the SSM.

Within the GoldSim ${ }^{\circledR}$ framework, the exchange volume and melt glass are represented as cell pathways with volume and porosity defined in Table 4-1. The near-field rock is represented as a GoldSim ${ }^{\circledR}$ pipe pathway. Figure 4-3 illustrates the conceptual model for the SSM within the GoldSim ${ }^{\circledR}$ framework.

Conceptually, the water flux through the melt glass and the exchange volume occur in parallel, each feeding the streamtube that represents flow in the aquifer as described in Tompson et al. (2004). In this manner the different time scales of radionuclide elution from the melt glass and the exchange volume are accounted for.

Each cell pathway (melt glass or exchange volume) is represented as a cubical volume. For a cube of volume, $V$, the characteristic length of each cubical volume is given by $\mathrm{V}^{1 / 3}$, or the length of an edge. The characteristic area of each face of the cube is given by $\mathrm{V}^{2 / 3}$. Based on the values in Table 4-1, the characteristic area and length of the 


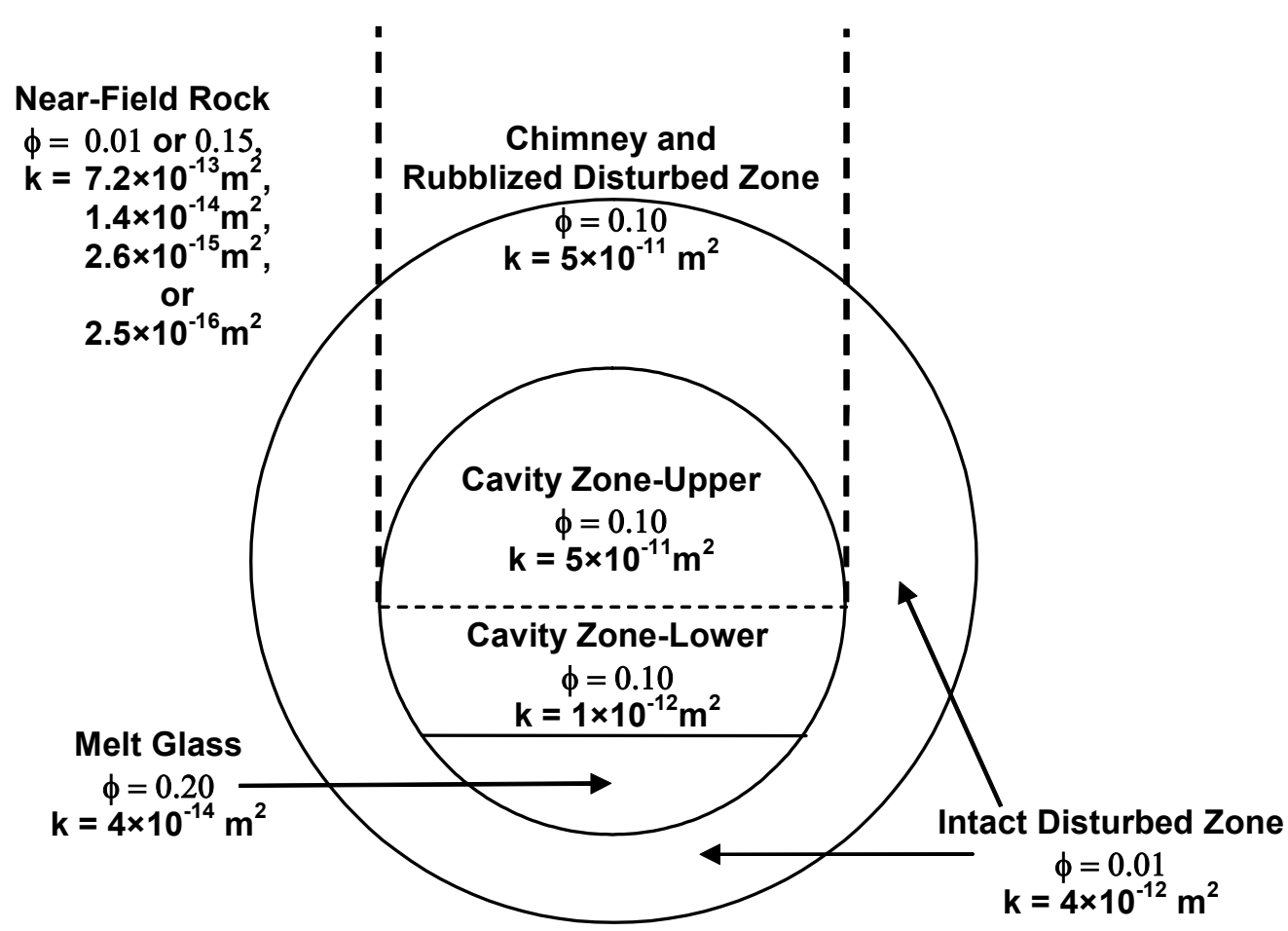

NOTES:

Melt glass, cavity, and chimney have matrix flow;

Intact disturbed zone has fracture flow;

Near-field rock has fracture flow if $\mathrm{k}=7.2 \times 10^{-13} \mathrm{~m}^{2}$ or $1.4 \times 10^{-14} \mathrm{~m}^{2}$ or matrix flow if $\mathrm{k}=2.6 \times 10^{-15} \mathrm{~m}^{2}$ or $2.5 \times 10^{-16} \mathrm{~m}^{2}$.

Figure 4-2

Hydrologic Properties for the Process Model of CHESHIRE (Pawloski et al., 2002)

exchange volume in the SSM is $42,007 \mathrm{~m}^{2}$ and 205.0 meters, respectively, and the characteristic area and length of the melt glass is $3,129 \mathrm{~m}^{2}$ and 55.9 meters, respectively. The concentration within each cell pathway is based on homogeneous conditions in chemical equilibrium with the sorption coefficients for the various radionuclides. Cell pathways also apply solubility and inventory constraints, although solubility constraints are not defined in the SSM (or in the process model) for CHESHIRE. The area of the pipe pathway is equal to the area of the exchange volume, $42,007 \mathrm{~m}^{2}$.

The fundamental output from GoldSim's ${ }^{\circledR}$ Contaminant Transport (CT) Module is the predicted mass fluxes at specified locations within the hydrological system. The CT Module is a mass transport model, not a flow model, and it does not directly solve for the movement of groundwater through the hydrological system. The fluxes between the exchange volume and the near-field pipe pathway, $Q_{E \text { b }}$ and between the melt glass and near-field pipe pathway, $Q_{M G}$ must be defined in an appropriate manner. In a sense, the quantities $Q_{E V}$ and $Q_{M G}$ are the fundamental 


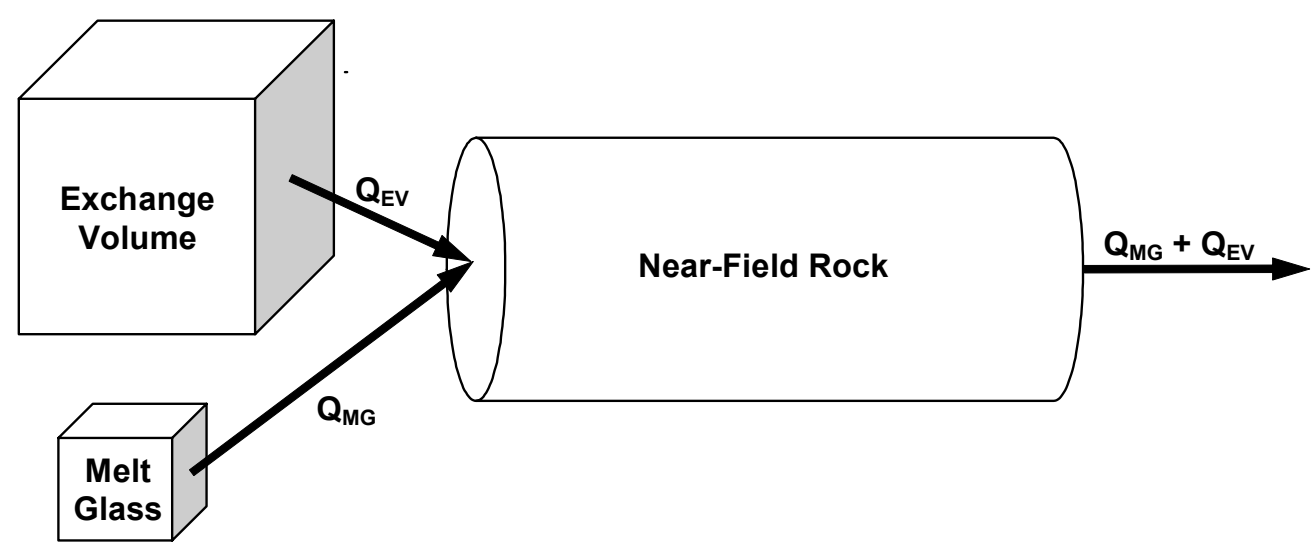

Figure 4-3

Schematic of the SSM Conceptual Model for the CHESHIRE TEST

inputs to the SSM, rather than the permeability of the various hydrologic media. Section 4.2 explains how the values of $Q_{E V}$ and $Q_{M G}$ are determined for the CHESHIRE test.

The SSM conceptual model is clearly a simplification of the flow system in the source region and in the near field. For example, the process model for CHESHIRE discretizes the individual source components (melt glass, cavity zone, and disturbed zone) with 10-meter zones, generating a complex, time-dependent flow field throughout the source. Similarly, the process-level model for CHESHIRE also creates 10 realizations of near-field permeability, based on a geostatistical approach that is calibrated with the measured thermal response in monitoring wells. The SSM assumes uniform conditions in each source zone (melt glass and exchange volume). In addition, the initial results reported here are based on a constant flux through the pipe pathway (i.e., a steady-state flow system as opposed to a transient flow system induced by thermal buoyancy effects). Thermal convection from the melt glass is not currently represented, although some initial testing was performed with a time dependent flux from the melt glass. Similarly, the single transport pipe does not represent the multiple pathways for flow and transport in the three-dimensional process model for CHESHIRE. In effect, the spatial variability of flow in a single realization of the process model for CHESHIRE is averaged into a single, randomly sampled value for the flux from the exchange volume.

\subsubsection{SSM Radionuclide Inventory and Its Partitioning}

The radionuclide inventory for the SSM is based on the 37 radionuclides identified by Pawloski et al. (2002, Table A-1) as appropriate for inclusion in the process model (see Table 4-2). The SSM inventory also represents decay and ingrowth for three radionuclide decay chains: 
Table 4-2

Initial Inventory and Distribution of Radionuclides for the Averaged Source Term for CHESHIRE (Pawloski et al. 2002, Table 4.3)

\begin{tabular}{|c|c|c|c|c|c|}
\hline \multirow{2}{*}{ Radionuclide } & \multirow{2}{*}{$\begin{array}{l}\text { Initial } \\
\text { Moles }\end{array}$} & \multicolumn{4}{|c|}{ Distribution (Percent of Initial Moles) } \\
\hline & & Lava $^{a}$ & Rubble & Gas & Water \\
\hline${ }^{3} \mathrm{H}$ & 31.6 & 0 & 0 & 2 & 98 \\
\hline${ }^{14} \mathrm{C}$ & 0.117 & 0 & 10 & 80 & 10 \\
\hline${ }^{36} \mathrm{Cl}$ & 2.37 & 50 & 40 & 0 & 10 \\
\hline${ }^{39} \mathrm{Ar}$ & 0.0183 & 0 & 10 & 80 & 10 \\
\hline${ }^{41} \mathrm{Ca}$ & 6.22 & 70 & 30 & 0 & 0 \\
\hline${ }^{59} \mathrm{Ni}$ & 0.112 & 95 & 5 & 0 & 0 \\
\hline${ }^{63} \mathrm{Ni}$ & 0.0155 & 95 & 5 & 0 & 0 \\
\hline${ }^{85} \mathrm{Kr}$ & 0.0378 & 0 & 10 & 80 & 10 \\
\hline${ }^{90} \mathrm{Sr}$ & 1.28 & 40 & 60 & 0 & 0 \\
\hline${ }^{93} \mathrm{Zr}$ & 2.30 & 95 & 5 & 0 & 0 \\
\hline${ }^{93 m} \mathrm{Nb}$ & 0.00450 & 95 & 5 & 0 & 0 \\
\hline${ }^{94} \mathrm{Nb}$ & 0.127 & 95 & 5 & 0 & 0 \\
\hline${ }^{99} \mathrm{Tc}$ & 2.41 & 80 & 20 & 0 & 0 \\
\hline${ }^{107} \mathrm{Pd}$ & 0.376 & 70 & 30 & 0 & 0 \\
\hline${ }^{121 \mathrm{~m}} \mathrm{Sn}$ & 0.00872 & 60 & 40 & 0 & 0 \\
\hline${ }^{126} \mathrm{Sn}$ & 0.181 & 70 & 30 & 0 & 0 \\
\hline${ }^{129} \mid$ & 0.544 & 50 & 40 & 0 & 10 \\
\hline${ }^{135} \mathrm{Cs}$ & 2.68 & 20 & 80 & 0 & 0 \\
\hline${ }^{137} \mathrm{Cs}$ & 1.68 & 20 & 80 & 0 & 0 \\
\hline${ }^{151} \mathrm{Sm}$ & 0.189 & 95 & 5 & 0 & 0 \\
\hline${ }^{150} \mathrm{Eu}$ & 0.00103 & 95 & 5 & 0 & 0 \\
\hline${ }^{152} \mathrm{Eu}$ & 0.0163 & 95 & 5 & 0 & 0 \\
\hline${ }^{154} \mathrm{Eu}$ & 0.00490 & 95 & 5 & 0 & 0 \\
\hline${ }^{166} \mathrm{Ho}$ & 0.00198 & 95 & 5 & 0 & 0 \\
\hline${ }^{232} U$ & 0.000657 & 90 & 10 & 0 & 0 \\
\hline${ }^{233} \mathrm{U}$ & 1.00 & 90 & 10 & 0 & 0 \\
\hline${ }^{234} U$ & 1.11 & 90 & 10 & 0 & 0 \\
\hline${ }^{235} U$ & 42.9 & 90 & 10 & 0 & 0 \\
\hline${ }^{236} \mathrm{U}$ & 4.07 & 90 & 10 & 0 & 0 \\
\hline${ }^{238} \mathrm{U}$ & 360 & 90 & 10 & 0 & 0 \\
\hline${ }^{237} \mathrm{~Np}$ & 2.87 & 95 & 5 & 0 & 0 \\
\hline${ }^{238} \mathrm{Pu}$ & 0.0231 & 95 & 5 & 0 & 0 \\
\hline${ }^{239} \mathrm{Pu}$ & 17.1 & 95 & 5 & 0 & 0 \\
\hline${ }^{240} \mathrm{Pu}$ & 1.50 & 95 & 5 & 0 & 0 \\
\hline${ }^{241} \mathrm{Pu}$ & 0.0475 & 95 & 5 & 0 & 0 \\
\hline${ }^{241} \mathrm{Am}$ & 0.0743 & 95 & 5 & 0 & 0 \\
\hline${ }^{244} \mathrm{Cm}$ & 0.00198 & 95 & 5 & 0 & 0 \\
\hline
\end{tabular}

an this report, "melt glass" is synonymous with the term "lava". 


$$
\begin{gathered}
{ }^{241} \mathrm{Pu} \rightarrow{ }^{241} \mathrm{Am} \rightarrow{ }^{237} \mathrm{~Np} \\
{ }^{238} \mathrm{Pu} \rightarrow{ }^{234} \mathrm{U} \\
{ }^{244} \mathrm{Cm} \rightarrow{ }^{240} \mathrm{Pu}
\end{gathered}
$$

The process model does not represent the second and third decay chains because the initial abundances of ${ }^{238} \mathrm{Pu}$ and ${ }^{244} \mathrm{Cm}$ are small relative to the abundances of the daughter products. However, the three chains are represented in the SSM because there is no significant computational penalty from maintaining the three decay chains in the SSM inventory.

A second difference between the process model inventory and the SSM inventory is that each of the 37 radionuclides listed in Table 4-2 is directly represented within GoldSim ${ }^{\circledR}$.

A third difference for the SSM inventory is that radioisotopes with half-lives greater than 70,000 years are not set as radioactive. A half-life greater than 70,000 years results in the decay of less than 1 percent of the initial inventory after 1,000 years. This change affects ${ }^{36} \mathrm{Cl},{ }^{41} \mathrm{Ca},{ }^{59} \mathrm{Ni},{ }^{93} \mathrm{Zr},{ }^{99} \mathrm{Tc},{ }^{107} \mathrm{Pd},{ }^{126} \mathrm{Sn},{ }^{129} \mathrm{I},{ }^{135} \mathrm{Cs}$, ${ }^{233} \mathrm{U},{ }^{234} \mathrm{U},{ }^{235} \mathrm{U},{ }^{236} \mathrm{U},{ }^{238} \mathrm{U}$, and ${ }^{237} \mathrm{~Np}$ in the SSM. If calculations with durations beyond 1,000 years are envisioned, this decision should be reevaluated. For example, a 10,000-year duration results in decay of less than 10 percent of the initial inventory for these radionuclides. Although this effect is modest, it will be simpler to allow radionuclide decay in long-duration calculations because the computational penalty is not significant.

The initial mass of each of the 37 radionuclides in Table 4-2 is based on an average of the inventories for 76 individual underground nuclear tests detonated below or within 100 meters of the water table in Areas 19 and 20 of Pahute Mesa on the Nevada Test Site (Pawloski et al., 2002, Section 4.4). This inventory provides an unclassified inventory for the SSM that is representative of a range of underground tests, but does not represent the actual inventory for the CHESHIRE test. This inventory was decay corrected to January 1, 1994. However, this is not time zero for CHESHIRE, but was used in the CHESHIRE HST process model without decay correction to time zero due to classification issues. Each of the radionuclides in Table 4-2 is directly represented as an individual radioisotope in the SSM, and the GoldSim ${ }^{\circledR}$ software automatically calculates decay (for half-life less than 70,000 years) and ingrowth of the three radionuclides decay chains identified at the beginning of this section.

The total inventory of each radionuclide is partitioned between the exchange volume and the melt glass, following the distribution of radionuclides into the lava, rubble, gas, and water developed by Pawloski et al. (2002, Table 4-3) for the process model. Thus, melt glass which has no ${ }^{14} \mathrm{C}$ inventory is saturated with water that does, resulting in ${ }^{14} \mathrm{C}$ in the melt glass pore space. The terms "lava", "rubble", "gas" and "water" are based on an International Atomic Energy Agency 
(IAEA) report (IAEA, 1998) and are interpreted (Tompson et al., 2004) as follows:

- "Lava" refers to the solidified melt glass. Radionuclides in the lava are not released until glass dissolution mobilizes them for transport in the groundwater.

- "Rubble" refers to the rubblized zones, excluding the melt glass. During the cooling process after a test, vaporized radionuclides in the rubble are assumed to condense throughout the pore spaces of the disturbed zone and the cavity zone (i.e., the exchange volume). These radionuclides are immediately available to dissolve and mobilize in the pore water when it returns after the test.

- "Water" refers to gaseous radionuclides in steam that would condense into liquid water as steam condensed. This condensation is assumed to occur in the pore spaces of the disturbed zone, the cavity zone, and the melt glass. These radionuclides are immediately available to dissolve and mobilize in the pore water when it returns after the test.

- "Gas" refers to noncondensible radionuclides that may exist as gases or coexist as bubbles in the pore fluids in the disturbed zone, cavity zone, and melt glass at normal pressures and temperatures. Again, these radionuclides are immediately available to dissolve and mobilize in the pore water when it returns after the test.

\subsubsection{Sorption}

The process model for CHESHIRE represents sorption of radionuclides using two different approaches: the GIMRT code and the particle code. The GIMRT code can incorporate surface complexation and ion exchange data, with varying groundwater chemistry. The particle code is limited to the simpler linear isotherm or partition coefficient $\left(\mathrm{K}_{\mathrm{d}}\right)$ approach and assumes that groundwater chemistry is constant at ambient conditions. The geochemistry for either code incorporates spatially varying mineralogic distributions, resulting in spatially heterogeneous sorbing mineral combinations in the fractures, cavity, chimney, and exchange volumes. Further details are provided in Chapter 6 and Appendices $F$ and $G$ of Pawloski et al. (2002).

The SSM represents near-field transport through a one-dimensional "pipe," assuming a linear isotherm with a constant value of the $\mathrm{K}_{\mathrm{d}}$ at ambient conditions. The SSM approach is similar to that for the particle code in that it is based on a linear isotherm and assumes constant groundwater chemistry. However, the SSM does not represent the three-dimensional spatial variability of sorption in either process model (GIMRT or particle code).

The retardation ratios (ratio of moles sorbed to moles in aqueous solution) for 11 elements (i.e., Am, Ca, Cm, Cs, Eu, Ho, Np, Pu, Sm, Sr, and U) for the SSM are presented in Table 4-3 in three media: fracture linings, cavity/chimney, and 
the rock matrix. The values in this table are based on the average log retardation ratios in Table K.8 of Pawloski et al. (2002). The partition coefficients in the fracture lining and cavity/chimney conditions are based on the presence or absence of 5 possible sorbing minerals: smectite, calcite, iron oxide, zeolite, and

illite/mica). For matrix flow, the selected minerals are always present, so the partition coefficient for the matrix is constant, without spatial variability. The use of the average log retardation ratios for the SSM is similar to the approach for the particle code in the process model, except that a single $\mathrm{K}_{\mathrm{d}}$ value is sampled for each realization, without spatial variability.

The SSM model represents the potential variability of retardation ratio for each of the 11 elements in the fracture lining and cavity/chimney by using a distribution for retardation ratio which is based on the presence or absence of the 5 minerals. For example, americium can be sorbed on smectite, calcite, and iron oxide (zeolite and illite/mica play no role in sorption of americium). The presence or absence of these minerals leads to $2^{3}$ or 8 possible states with 8 discrete values of the retardation ratio, each of which is assumed equally likely for the SSM. The calculation of the discrete values for the distribution is illustrated in Table 4-4.

The discrete distribution of $\mathrm{K}_{\mathrm{d}}$ values for americium in the SSM is essentially bimodal, with four lower values between 27 and 125, four upper values between 616 and 713, and no intermediate values. This feature arises because one mineral tends to have the dominant contribution to the retardation ratio, so that turning it on or off leads to a bimodal response. In the case of americium for fracture flow, this dominant mineral is calcite, but similar behavior is observed for all other elements. This bimodal behavior means that the SSM transport calculations are sampling the extremes of the $\mathrm{K}_{\mathrm{d}}$ values, rather than the full range of effective $\mathrm{K}_{\mathrm{d}}$ values that would likely occur with the three-dimensional, spatial distribution for the particle code. In other words, developing a three-dimensional spatial distribution will tend to average out the differences in the sampled $\mathrm{K}_{\mathrm{d}}$ values, while the SSM picks only a single value for each realization.

The retardation ratio $(R R)$ is defined as the ratio of moles sorbed to moles in aqueous solution (Pawloski et al., 2002, Appendix K.8). Since the retardation factor, $R F$, is defined as the ratio of total moles to moles in aqueous solution, $R F=R R+1$. The value of the $K_{\mathrm{d}}$ can then be determined from:

$$
R F=R R+1=1+\frac{\rho_{b} K_{\mathrm{d}}}{\phi}
$$

which implies that

$$
K_{\mathrm{d}}=\frac{\phi R R}{\rho_{b}}
$$

where

$\phi \quad=$ The porosity

$R R \quad=$ The retardation ratio

$\rho_{\mathrm{b}} \quad=$ The bulk density of the material. 
Table 4-3

Average Log Retardation Ratios for Heterogeneous Mineral Distributions

(Pawloski et al., 2002, Table K.8)

(Page 1 of 2)

\begin{tabular}{|c|c|c|c|c|c|}
\hline & \multicolumn{2}{|c|}{ Fracture Lining } & \multicolumn{2}{|c|}{ Cavity/Chimney Rubble } & \multirow{2}{*}{ Rock Matrix } \\
\hline & $1=0 n$ & $0=$ Off & $1=0 n$ & $0=0$ ff & \\
\hline \multicolumn{6}{|c|}{ Am } \\
\hline Smectite & 2.06 & 1.42 & 0.92 & -0.52 & 3.67 \\
\hline Calcite & 2.77 & -3.84 & 1.73 & -4.84 & -3.00 \\
\hline Iron Oxide & 0.99 & -0.05 & -0.08 & -1.99 & 2.20 \\
\hline Zeolite & -- & -- & -- & -- & -- \\
\hline Illite/mica & -- & -- & -- & -- & -- \\
\hline \multicolumn{6}{|c|}{$\mathrm{Ca}$} \\
\hline Smectite & 2.15 & 1.52 & 1.01 & -0.43 & 1.75 \\
\hline Calcite & 0.85 & -5.77 & -0.19 & -6.76 & -6.93 \\
\hline Iron Oxide & -- & -- & -- & -- & -- \\
\hline Zeolite & 2.65 & -26.81 & 1.61 & -26.81 & -26.81 \\
\hline Illite/mica & 0.07 & 0.07 & -1.87 & -1.87 & 0.31 \\
\hline \multicolumn{6}{|c|}{ Cs } \\
\hline Smectite & 1.16 & 0.52 & 0.02 & -1.42 & 0.76 \\
\hline Calcite & -- & -- & -- & -- & -- \\
\hline Iron Oxide & -- & -- & -- & -- & -- \\
\hline Zeolite & 2.71 & -26.76 & 1.67 & -26.76 & -26.76 \\
\hline Illite/mica & 2.48 & 2.48 & 0.53 & 0.53 & 2.71 \\
\hline \multicolumn{6}{|c|}{$\mathrm{Eu}, \mathrm{Ho}$, and $\mathrm{Cm}$} \\
\hline Smectite & 2.04 & 1.41 & 0.90 & -0.54 & 3.02 \\
\hline Calcite & 3.26 & -3.35 & 2.23 & -4.34 & -3.14 \\
\hline Iron Oxide & 1.57 & 0.54 & 0.50 & -1.41 & 2.15 \\
\hline Zeolite & -- & -- & -- & -- & -- \\
\hline Illite/mica & -- & -- & -- & -- & -- \\
\hline \multicolumn{6}{|c|}{$\mathrm{Np}$} \\
\hline Smectite & 0.37 & -0.27 & -0.77 & -2.21 & -0.02 \\
\hline Calcite & 2.12 & -4.50 & 1.08 & -5.49 & -5.66 \\
\hline Iron Oxide & 1.48 & 0.45 & 0.41 & -1.50 & 0.69 \\
\hline Zeolite & -- & -- & -- & -- & -- \\
\hline Illite/mica & -- & -- & -- & -- & -- \\
\hline \multicolumn{6}{|c|}{$\mathrm{Pu}$} \\
\hline Smectite & 1.14 & 0.51 & 0.00 & -1.44 & 0.80 \\
\hline Calcite & 2.04 & -4.57 & 1.00 & -5.56 & -5.68 \\
\hline
\end{tabular}


Table 4-3

Average Log Retardation Ratios for Heterogeneous Mineral Distributions

(Pawloski et al., 2002, Table K.8)

(Page 2 of 2)

\begin{tabular}{|c|c|c|c|c|c|}
\hline & \multicolumn{2}{|c|}{ Fracture Lining } & \multicolumn{2}{|c|}{ Cavity/Chimney Rubble } & \multirow{2}{*}{ Rock Matrix } \\
\hline & 1 = On & $0=$ Off & $1=0 n$ & $0=$ Off & \\
\hline Iron Oxide & 1.84 & 0.80 & 0.76 & -1.14 & 1.09 \\
\hline Zeolite & -- & -- & -- & -- & -- \\
\hline Illite/mica & -- & -- & -- & -- & -- \\
\hline \multicolumn{6}{|c|}{ Sm } \\
\hline Smectite & 2.05 & 1.41 & 0.91 & -0.53 & 3.18 \\
\hline Calcite & 3.64 & -2.97 & 2.60 & -3.97 & -2.60 \\
\hline Iron Oxide & 1.58 & 0.54 & 0.50 & -1.40 & 2.31 \\
\hline Zeolite & -- & -- & -- & -- & -- \\
\hline Illite/mica & -- & -- & -- & -- & -- \\
\hline \multicolumn{6}{|c|}{$\mathrm{Sr}$} \\
\hline Smectite & 2.15 & 1.52 & 1.01 & -0.43 & 1.75 \\
\hline Calcite & -0.90 & -7.52 & -1.94 & -8.51 & -8.68 \\
\hline Iron Oxide & -0.55 & -1.58 & -1.62 & -3.52 & -1.35 \\
\hline Zeolite & 2.80 & -26.67 & 1.76 & -26.67 & -26.67 \\
\hline Illite/mica & 0.07 & 0.07 & -1.87 & -1.87 & 0.30 \\
\hline \multicolumn{6}{|c|}{$\mathbf{U}$} \\
\hline Smectite & 0.62 & -0.02 & -0.52 & -1.96 & 0.23 \\
\hline Calcite & -1.74 & -8.36 & -2.78 & -9.35 & -9.51 \\
\hline Iron Oxide & 2.13 & 1.10 & 1.06 & -0.85 & 1.34 \\
\hline Zeolite & -- & -- & -- & -- & -- \\
\hline Illite/mica & -- & -- & -- & -- & -- \\
\hline
\end{tabular}

Table 4-4

Definition of the Discrete Distribution for the Retardation Ratio of Americium in the Fracture Lining

\begin{tabular}{|c|c|c|c|c|c|c|c|c|c|c|}
\hline \multicolumn{3}{|c|}{ Average Log Retardation Ratio } & \multirow{2}{*}{\multicolumn{8}{|c|}{ Mineralogic Condition }} \\
\hline Mineral & 1 (On State) & 2 (Off State) & & & & & & & & \\
\hline Smectite & 2.06 & 1.42 & 1 & 1 & 1 & 0 & 0 & 0 & 1 & 0 \\
\hline Calcite & 2.77 & -3.84 & 1 & 1 & 0 & 1 & 0 & 1 & 0 & 0 \\
\hline Iron oxide & 0.99 & -0.05 & 1 & 0 & 1 & 1 & 1 & 0 & 0 & 0 \\
\hline \multicolumn{3}{|c|}{ Total Retardation Ratio for the Given State } & 713.4 & 704.6 & 124.6 & 624.9 & 36.1 & 616.0 & 115.7 & 27.2 \\
\hline
\end{tabular}


Section 6.2.2.3 of Pawloski et al. (2002) provides a detailed development of the fracture morphology in the near field rock. Based on the requirement to match the porosity in the near-field hydrology and geochemistry process models, each side of a fracture has a 0.1 -millimeter $(\mathrm{mm})$ thick fracture lining on top of a $2.5-\mathrm{mm}$ thick matrix lining. Groundwater can flow through the fracture lining.

The SSM directly represents the fracture lining and matrix lining in the near field transport pathway. The flow area in the fractures in the near-field rock is set to provide 1 percent porosity, so the matrix lining is a diffusive zone but not an advective zone. In each realization of the SSM, the model samples the distributions for retardation ratio for each element. The retardation ratios for the fracture lining and the retardation ratios for the matrix are applied as matrix diffusion zones for the media lining the transport pathway. The constant values for retardation ratio for the cavity/chimney are applied throughout the exchange volume in the SSM.

\subsubsection{Glass Dissolution}

The SSM incorporates the same simplified temperature-dependent glass dissolution model that is used for the particle code in the process model. The glass reaction rate is based on a moderate rate at $25^{\circ} \mathrm{C}$ that represents a conservative estimate of the glass dissolution rate at near-ambient chemical conditions (Pawloski et al., 2002, Section 6.4.5.1 and Figure 6.20). The value of this rate per reactive surface area of glass is $6.693 \times 10^{-12}$ moles per square meter per second $\left(\mathrm{mol} / \mathrm{m}^{2} / \mathrm{s}\right)$ (Pawloski et al., 2002, Section 6.4.5.1.2). To calculate the bulk rate of dissolution for the melt glass, this rate is multiplied by the reactive surface area, defined as $0.001 \mathrm{~m}^{2}$ per gram of melt glass (Pawloski et al., 2002, Section 6.4.4.4.3); the molecular weight of the glass is defined as 100 grams (Pawloski et al., 2002, Figure 6.20). The Arrhenius equation (Pawloski et al. 2002, Section 6.4.5.2) is then used to calculate the dissolution rate at temperature T:

$$
\ln \left(\frac{k_{2}}{k_{1}}\right)=\frac{E_{a}}{R} \frac{T_{2}-T_{1}}{T_{2} T_{1}}
$$

where

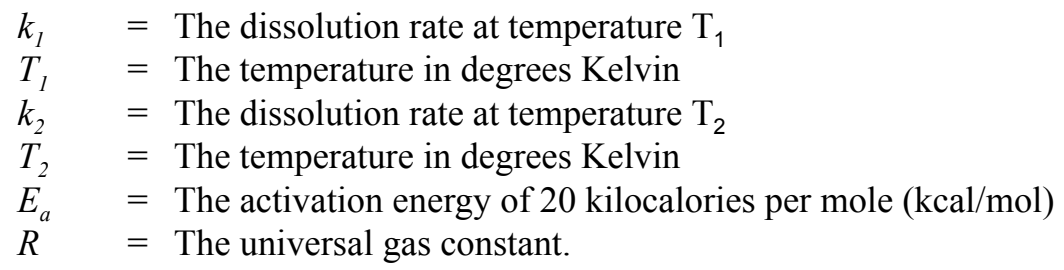

The temperature of the melt glass varies between $160{ }^{\circ} \mathrm{C}$ at early time to approximately $39^{\circ} \mathrm{C}$ at 1,000 years after the test (Pawloski et al., 2002, Figure E.5 in Appendix E). Since the dissolution rate from Equation (4-8) is sensitive to the value of temperature, a lookup table based on the digitized temperature time 
history is included in the SSM. The values for this digitized history are given in Table 4-5.

Table 4-5

Digitized Temperature Time History in the Melt Glass for the SSM

\begin{tabular}{|c|c|}
\hline Time (Years) & $\begin{array}{c}\text { Temperature } \\
\left({ }^{\circ} \mathbf{C}\right)\end{array}$ \\
\hline \hline 0.001 & 160 \\
\hline 0.01 & 160 \\
\hline 0.02 & 159.3 \\
\hline 0.05 & 158 \\
\hline 0.1 & 154.7 \\
\hline 0.2 & 149.7 \\
\hline 0.5 & 132 \\
\hline 1 & 118.7 \\
\hline 2 & 94.7 \\
\hline 5 & 70.7 \\
\hline 10 & 56 \\
\hline 20 & 48 \\
\hline 50 & 41.7 \\
\hline 100 & 39.3 \\
\hline 200 & 39 \\
\hline 500 & 38.7 \\
\hline 1000 & 38.7 \\
\hline
\end{tabular}

\subsection{Mass Fluxes for Tracer Radionuclides}

The cell and pipe pathways in the SSM are a mass transport model, not a flow model, and do not solve for the movement of groundwater through the hydrological system. In this situation, the fluxes between the exchange volume and the near-field pipe pathway, $Q_{E}$ and between the melt glass and near-field pipe pathway, $Q_{M G}$ must be defined in an appropriate manner. These flows approximate the true non-isothermal transient system.

The approach to defining $Q_{E V}$ and $Q_{M G}$ is to use an analytic solution for the conceptual model in Figure 4-3 to define the initial ranges for these parameters, followed by computational testing for three nonsorbing (tracer) radionuclides $\left({ }^{14} \mathrm{C}\right.$, ${ }^{3} \mathrm{H}$, and ${ }^{59} \mathrm{Ni}$ ). These three tracers were selected because they are likely to represent the extremes in behavior for all tracer radionuclides. ${ }^{14} \mathrm{C}$ and ${ }^{3} \mathrm{H}$ are distributed throughout the pore water in the exchange volume and melt glass, there is no inventory in the melt glass matrix. ${ }^{14} \mathrm{C}$ has a long half-life $(5,730$ years), while ${ }^{3} \mathrm{H}$ has a short half-life (12.3 years). ${ }^{59} \mathrm{Ni}$ has 95 percent of its initial inventory in the melt glass matrix, which is the maximum value among all tracer radioisotopes. ${ }^{59} \mathrm{Ni}$ also has a long half-life, 76,000 years, so decay is not a factor in its breakthrough curve. 


\subsubsection{Analytic Solution}

The analytic solution for release of ${ }^{3} \mathrm{H}$ or ${ }^{14} \mathrm{C}$ (or any tracer with no inventory in the melt glass matrix) from the exchange volume and cell pathways is very straight forward. Since there is no inventory in the melt glass matrix, the mass in each cell pathway is given by:

$$
\frac{d M_{i}(t)}{d t}=c_{i}(t) Q_{i}
$$

or

$$
\frac{d M_{i}(t)}{d t}=\frac{M_{i}(t)}{V_{p, i}} Q_{i} \text { for } i=\text { melt glass }(\mathrm{MG}) \text { or exchange volume (EV) }
$$

where

$M_{i}(t)=$ The mass at time $t(\mathrm{M})$

$c_{i}(t)=$ The concentration $\left(\mathrm{M} / \mathrm{L}^{3}\right)$

$Q_{i}=$ The outward flux $\left(\mathrm{L}^{3}\right)$

$V_{p, i}=$ The pore volume in the $i^{\text {th }}$ cell pathway (no units)

This relationship assumes a well-mixed condition that may or may not exist at the downgradient control plane, in the geostatistically-based process model.

Assuming that the flux $Q_{i}$ is constant, the mass in the cell pathway is given by:

$$
M_{i}(t)=M_{i}(0) e^{-\frac{Q_{i}}{V_{p, i}} t}
$$

and the time-dependent mass flux from the cell pathway, $F_{i}(t)$, is then:

$$
F_{i}(t)=\frac{M_{i}(t)}{V_{p, i}} Q_{i}=\frac{M_{i}(0) Q_{i}}{V_{p, i}} e^{-\frac{Q_{i}}{V_{p, i}}} .
$$

Since both the melt glass and exchange volume contribute to the flux, the total flux, $F(t)$, from the melt glass and exchange volume is given by:

$$
F(t)=\frac{M_{E V}(0) Q_{E V}}{V_{p, E V}} e^{-\frac{Q_{E V}}{V_{p, E V}} t}+\frac{M_{M G}(0) Q_{M G}}{V_{p, M G}} e^{-\frac{Q_{M G}}{V_{p, M G}} t}
$$

A key observation is that each of the cell pathways contributes over a different time scale to the flux. At early times, say less than the first 100 years, the first (EV) term is dominant. At 1,000 years, the second (MG) term is dominant. The relative magnitudes of $Q_{E V}$ versus $Q_{M G}$ can be estimated from the formula for steady-state flow in a saturated medium: $Q=K i A$, where $K$ is conductivity, $i$ is the head gradient, and $A$ is the cross-sectional area of the flow. The cross-sectional area of the exchange volume, $42,007 \mathrm{~m}^{2}$, is more than a factor of 13 greater than the cross-sectional area of the melt glass, $3,129 \mathrm{~m}^{2}$. The hydraulic conductivity of 
the disturbed zone and upper cavity zone is more than a factor of 250 greater than the hydraulic conductivity in the melt glass, based on the permeabilities in Section 4.1.2 and the fact that conductivity is proportional to permeability. Finally, the local head gradients should be similar in magnitude because the melt glass is physically embedded in the larger exchange volume. While this simple analysis is an approximation for a complex source, it is clear that $Q_{E V}$ will be several orders of magnitude greater than $Q_{M G}$ In this situation, radionuclides in the exchange volume are rapidly advected out of the exchange volume and transported to the release boundary shortly after the test, while the radionuclides in the melt glass leak out more slowly and dominate releases near 1,000 years.

The tracer radionuclides do not sorb in the exchange volume melt glass or near-field rock. Neglecting dispersion in the near-field pathway, the mass flux from the pipe pathway will be identical to Equation (4-13) except for a temporal shift due to the delay in mass advecting through the pipe pathway. This delay is relatively brief, as will be shown later, so it is ignored in this discussion.

\subsubsection{Comparison to ${ }^{14} \mathrm{C}$ Mass Flux From Process Model}

Equation (4-13) has been used to determine the value of $Q_{i}$ that matches the breakthrough flux from the process model for ${ }^{14} \mathrm{C}$. The decay-corrected breakthrough fluxes from the process model for all 37 radionuclides are available in Figures 7.40(a) through 7.40(e) of Pawloski et al. (2002). Figure 4-4 shows the breakthrough curve for ${ }^{14} \mathrm{C}$ from Pawloski et al. (2002).

The peak mass fluxes in Figure 4-4 ${ }^{1}$ can be used to determine a range of values for $Q_{E}$. As an approximation, the mass flux in Equation (4-13) is evaluated at time zero and the contribution from the melt glass is ignored. The initial mass flux, $F(0)$, is given by:

$$
F(0)=\frac{M_{E V}(0) Q_{E V}}{V_{p, E V}}
$$

The values of $Q_{E V}$ for the $5^{\text {th }}$, median, and $95^{\text {th }}$ percentile values of peak mass flux are given in Table 4-6.

A similar procedure can be applied to determine $Q_{M G}$ based on the mass flux of ${ }^{14} \mathrm{C}$ at 1,000 years, with the results shown in Table 4-7. Ignoring the contribution from the exchange volume, the mass flux at 1,000 years is given by:

$$
F(1,000 y r s)=\frac{M_{M G}(0) Q_{M G}}{V_{p, M G}} e^{-\frac{Q_{M G}}{V_{p, M G}} \times(1,000)}
$$

1. Digitized versions of all breakthrough curves were provided by LLNL and are the basis for the numerical values in Table 4-6. 


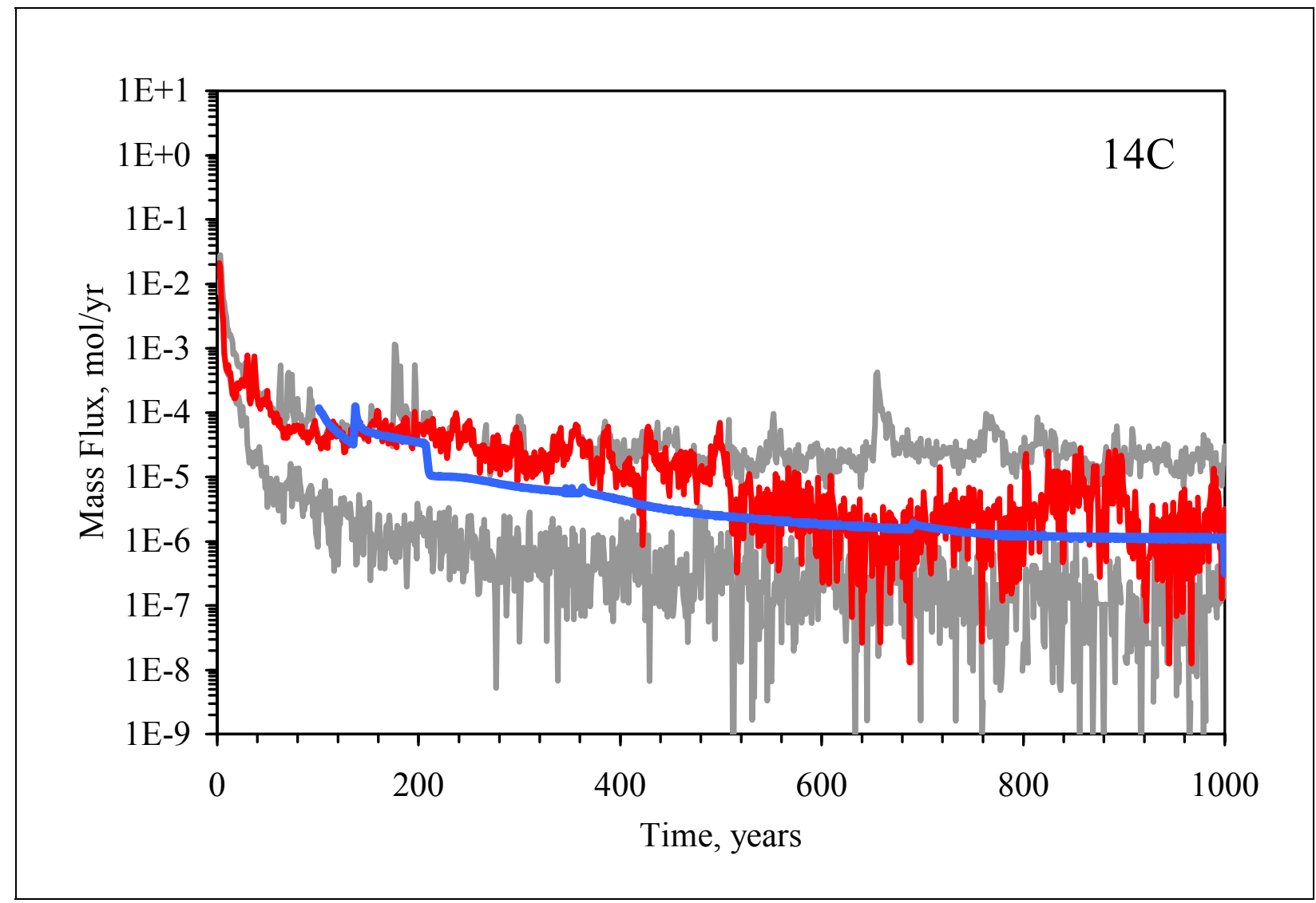

Figure 4-4

Breakthrough Curves from the Process Model for ${ }^{14} \mathrm{C}$.

GIMRT Results In Blue, Mean Particle Model Results In Red, $5^{\text {th }}$ and $95^{\text {th }}$ Percentiles of Particle Model Results In Grey

Table 4-6

Estimate of $Q_{E V}$ Based on Peak Mass Fluxes for ${ }^{14} \mathrm{C}$

\begin{tabular}{|c|c|c|}
\hline & $\begin{array}{c}\text { Peak Mass Flux } \\
\text { (mol/year) }\end{array}$ & $\begin{array}{c}\mathbf{Q}_{\mathrm{EV}} \\
\left.\text { ( } \mathbf{m}^{3} / \mathbf{y e a r}\right)\end{array}$ \\
\hline \hline $5^{\text {th }}$ Percentile & 0.0127 & $47,200$. \\
\hline Mean & 0.0185 & $68,600$. \\
\hline $95^{\text {th }}$ Percentile & 0.0278 & $103,000$. \\
\hline
\end{tabular}

NOTES:

$M_{E V}(0)=0.109$ moles based on partitioning in Table 4-2

$V_{p, E V}=4.03 \times 10^{5} \mathrm{~m}^{3}$ (see Table 4-1) 
Table 4-7

Estimate of $Q_{\mathrm{MG}}$ Based on Mass Fluxes at 1,000 Years for ${ }^{14} \mathrm{C}$

\begin{tabular}{|c|c|c|}
\hline & $\begin{array}{c}\text { Mass Flux at 1,000 Years } \\
\text { (mol/year) }\end{array}$ & $\begin{array}{c}\mathbf{Q}_{\text {MG }} \\
\left(\mathbf{m}^{3} / \mathbf{y e a r}\right)\end{array}$ \\
\hline \hline $5^{\text {th }}$ Percentile & $1.87 \times 10^{-7}$ & 190. \\
\hline Mean & $2.01 \times 10^{-6}$ & 78.6 \\
\hline $95^{\text {th }}$ Percentile & $2.05 \times 10^{-5}$ & No solution \\
\hline
\end{tabular}

NOTES:

$M_{M G}(0)=0.00841$ moles based on partitioning in Table 4-2

$V_{p, M G}=35,000 \cdot \mathrm{m}^{3}$ (see Table 4-1)

Given the large variability in the time histories in Figure 4-4, the flux from the process model at 1,000 years was determined by averaging 25 data points between 975 years and 1,000 years.

The results in Tables 4-6 and 4-7 confirm the argument that $\mathrm{Q}_{\mathrm{EV}}$ is several orders of magnitude greater than $\mathrm{Q}_{\mathrm{MG}}$ It is also useful to calculate $\left(V_{p, E V} / Q_{E V}\right)$, which is the characteristic time in the first exponential term in Equation (4-13). Based on the values of $Q_{E V}$ in Table 4-6, the characteristic time varies between 4 and 85 years, confirming that mass is quickly swept out of the exchange volume. The characteristic times for the melt glass, based on the values of $Q_{M G}$ in Table 4-7, vary between 184 and 445 years, confirming its slower release. It is clear that the first (EV) term in Equation (4-13) is dominant at early times whiles the second (MG) term in Equation (4-13) is dominant at 1,000 years.

The results in Table 4-7 indicate that there is no solution for the $95^{\text {th }}$ percentile flux with Equation (15). An analysis of Equation (15) as a function of $Q_{M G}$ indicates that the flux is zero when $Q_{M G}$ is 0 or very large, and has a maximum between these two values, as illustrated in Figure 4-5. The maximum value occurs at $Q_{M G}=V_{p, M G} /(1,000$ years $)=35 \mathrm{~m}^{3}$ per year, and results in a peak flux of $3.10 \times 10^{-6}$ moles per year.

The lack of a solution for the peak flux indicates that the conceptual model in Figure 4-3 does not represent all of the multiple radionuclide pathways and associated travel times generated by a three-dimensional permeability fields in the process model. This interpretation is confirmed by a simple calculation. The $95^{\text {th }}$ percentile flux in Figure 4-4 is always greater than $2.05 \times 10^{-5}$ moles per year, implying that the total release over 1,000 years is greater than 0.0205 moles. Since the initial ${ }^{14} \mathrm{C}$ inventory in the melt glass is only 0.0084 moles, some inventory in the exchange volume must be moving along slower pathways that are not represented in the present conceptual model.

A second observation from Figure 4-5 is that, when a solution does exist, there are two values of $Q_{M G}$ that will match a given value of the mass flux. The solutions in Tables 4-4 and 4-5 are based on the larger values of $Q_{M G}$ because the releases from the process model are usually dominated by the fast fracture pathways with higher 


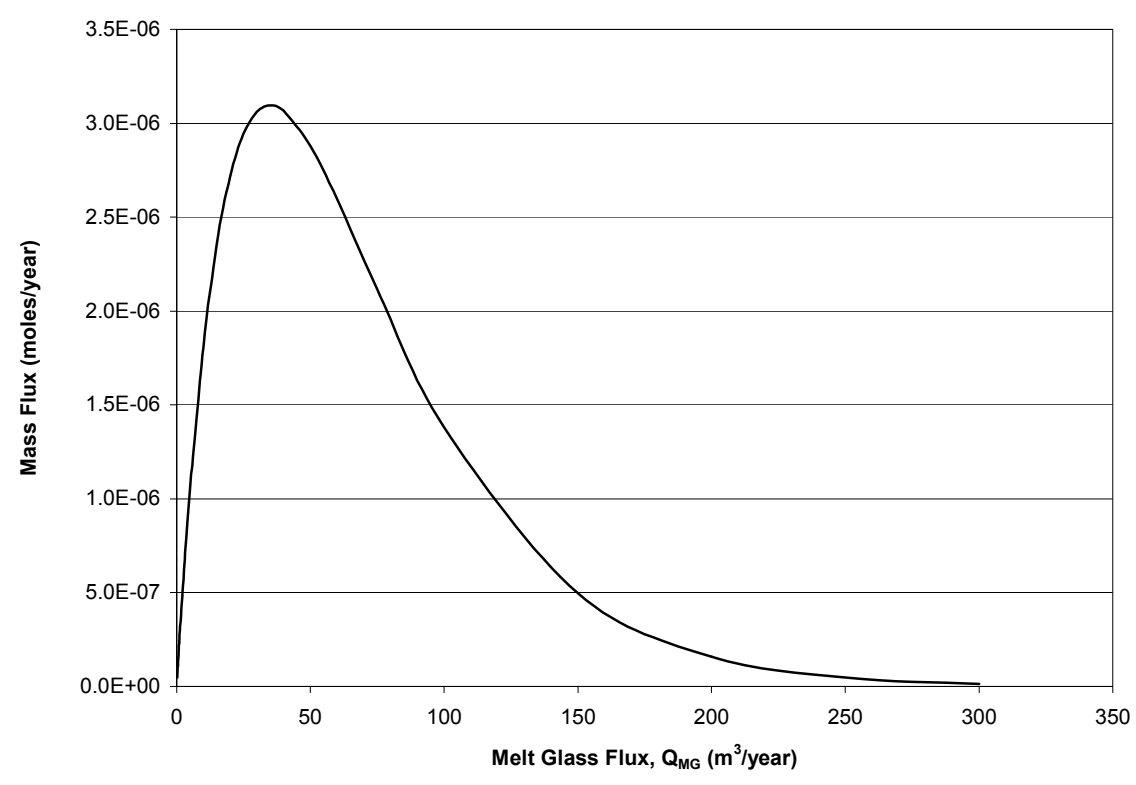

Figure 4-5

Plot of Mass Flux as a Function of $\mathbf{Q}_{\mathrm{MG}}$ in Equation 4-15

values for near-field permeability. However, the range of $Q_{M G}$ has been expanded during the numerical testing to produce a better match to the range of solutions for the process model.

\subsubsection{Comparisons for ${ }^{14} \mathrm{C},{ }^{3} \mathrm{H}$, and ${ }^{59} \mathrm{Ni}$}

Figures 4-6, 4-7, and 4-8 present comparisons of the SSM fluxes with the process model fluxes for ${ }^{14} \mathrm{C},{ }^{3} \mathrm{H}$, and ${ }^{59} \mathrm{Ni}$. The ranges of $Q_{E V}$ and $Q_{M G}$ defined in Tables 4-6 and 4-7 were the starting point for numerical testing. The goal of this testing was to determine appropriate ranges of $Q_{E V}$ and $Q_{M G}$ that provided the best fits to the peak fluxes at time zero and to the fluxes at 1,000 years for these radionuclides. The final range of $Q_{E V}$ is 60,000 to $140,000 \mathrm{~m}^{3} /$ year, which can be compared to the initial range of 47,000 to $103,000 \mathrm{~m}^{3} /$ year in Table $4-5$. The final range of $Q_{M G}$ is 1 to $250 \mathrm{~m}^{3} /$ year, which can be compared to the initial range of 79 to $190 \mathrm{~m}^{3} /$ year in Table 4-6. Note that the range of $Q_{M G}$ has been extended into the second set of low permeability solutions.

The range for $Q_{E V}$ defines the upper and lower bounds of a uniform distribution in the SSM. Similarly, the range $Q_{M G}$ defines the limits for a second uniform distribution in the SSM. A uniform distribution is appropriate here because this analysis defines the upper and lower bounds, with no insights into the distribution of $Q_{i}$ (or equivalently of travel times) from the three-dimensional process model. These distributions are sampled once during each realization of the SSM, providing a single, constant value for $Q_{E V}$ and a single constant value for $Q_{M G}$ 


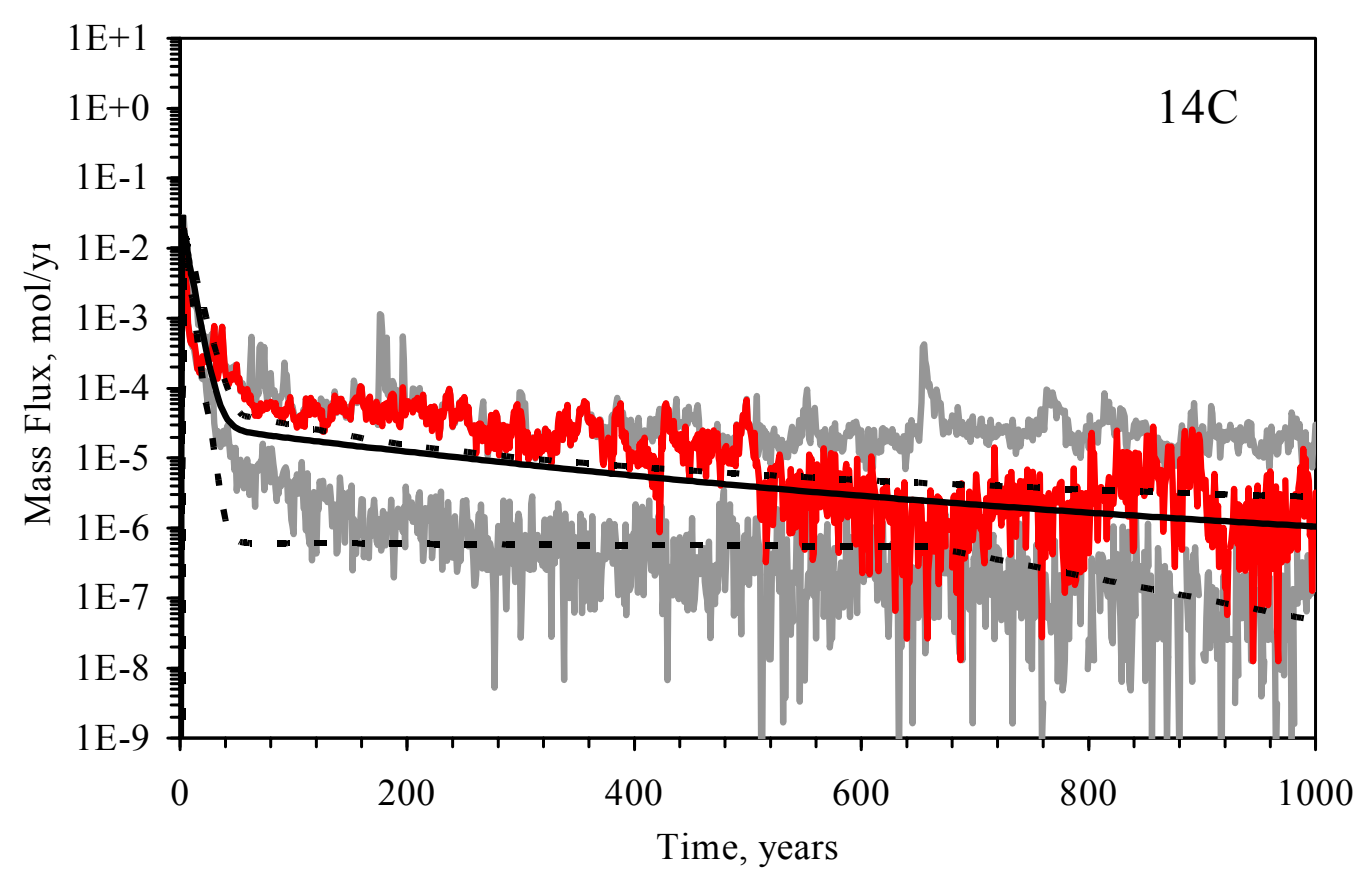

Figure 4-6

Comparison of ${ }^{14} \mathrm{C}$ Exit Mass Fluxes from the Process Model with the SSM.

Particle Model Results: Mean (Red), $5^{\text {th }}$ and $95^{\text {th }}$ Percentiles (Grey); SSM Results: Mean (Solid Black), Maximum and Minimum (Dashed Black)

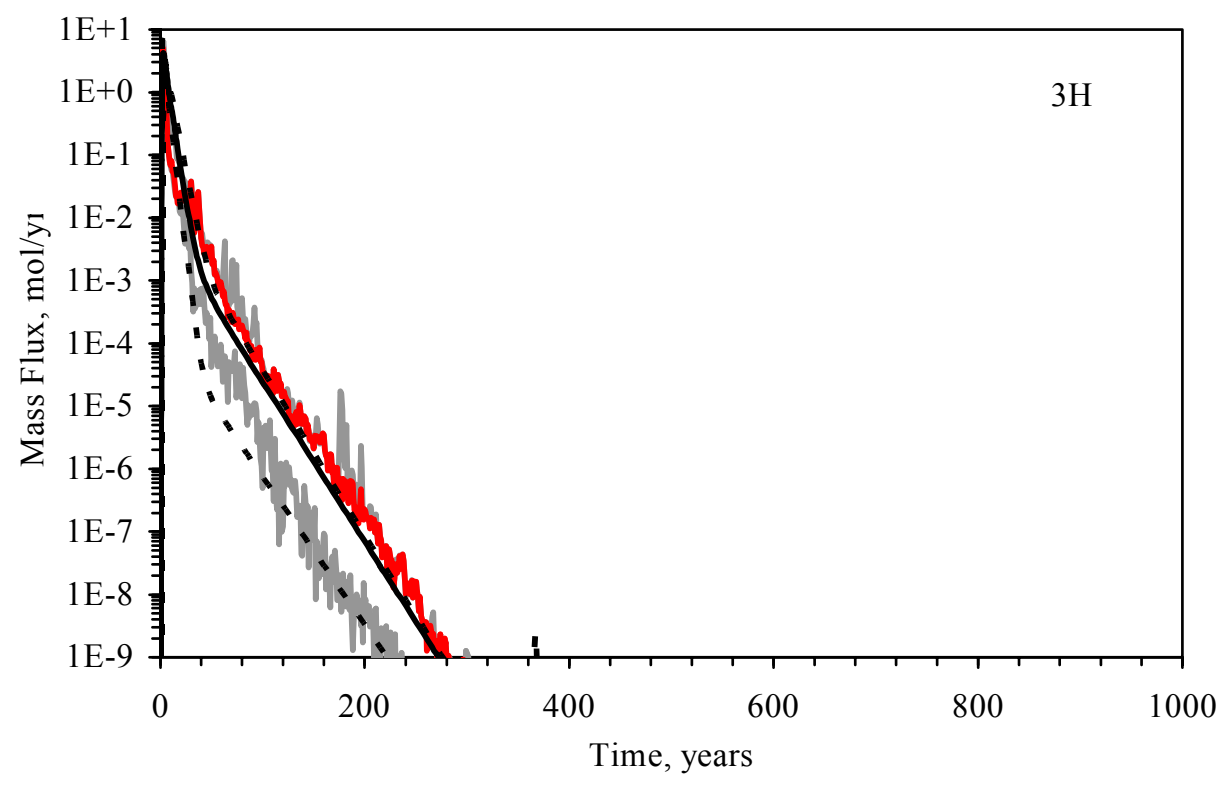

Figure 4-7

Comparison of ${ }^{3} \mathrm{H}$ Mass Fluxes from the Process Model with the SSM.

Particle Model Results: Mean (Red), $5^{\text {th }}$ and $95^{\text {th }}$ Percentiles (Grey); SSM Results: Mean (Solid Black), Maximum and Minimum (Dashed Black) 


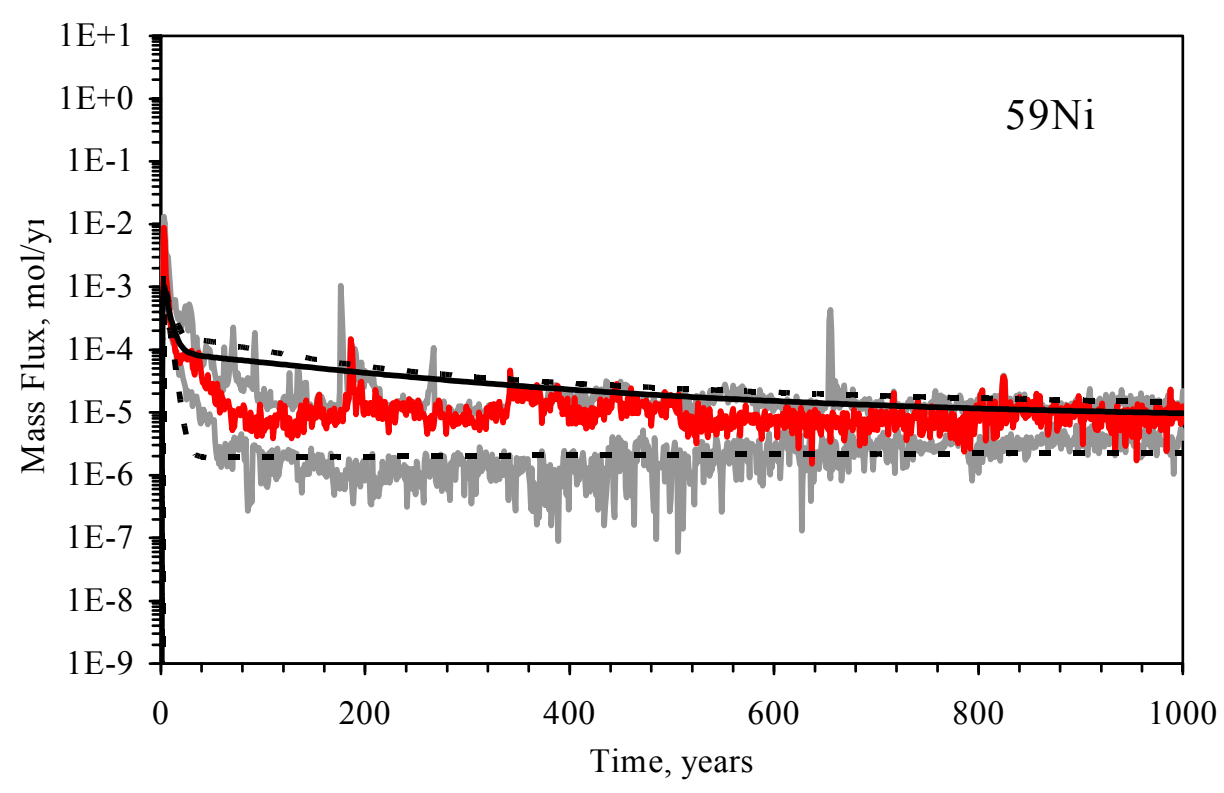

Figure 4-8

Comparison of ${ }^{59} \mathrm{Ni}$ Mass Fluxes from the Process Model with the SSM.

Particle Model Results: Mean (Red), $5^{\text {th }}$ and $95^{\text {th }}$ Percentiles (Grey);

SSM Results: Mean (Solid Black), Maximum and Minimum (Dashed Black)

A total of 40 realizations were performed using Latin Hypercube sampling for each SSM calculation. Each realization has 307 cycles, with time steps increasing from 0.00412 years at the start of the calculation to 4.22 years after 100 years. The variable time steps are designed to improve numerical accuracy when the melt glass degradation rates are highest, at the start of the calculation. Numerical testing with approximately 1,000 cycles indicated that the current approach, with 307 cycles, provided accurate predictions of the mass flux from the system. Each realization requires 8 seconds of (wall) clock time on an Intel Pentium ${ }^{\circledR} \mathrm{M}$ microprocessor with an internal clock speed of 1,600 Megahertz and 512 megabytes of RAM; the operating system is Windows XP Professional. Total run time for 40 realizations is about 5 minutes.

Figure 4-6 indicates good agreement for the peak (initial) mass fluxes for ${ }^{14} \mathrm{C}$ and for $5^{\text {th }}$ percentile and mean mass flux at 1,000 years. However, as explained above, the SSM cannot match the $95^{\text {th }}$ percentile mass flux at 1,000 years.

Figure 4-7 indicates very good agreement between the process model and the SSM for tritium release. Figure 4-8 indicates very good agreement between the process model and the SSM for the late-time releases of ${ }^{59} \mathrm{Ni}$. However, the peak initial fluxes from the SSM are substantially below the peak fluxes from the process model. As a reminder, ${ }^{59} \mathrm{Ni}$ has 95 percent of its mass in the melt glass matrix, so the underestimate by the SSM may indicate a small pathway with very rapid travel time or may indicate the effects of convection on the initial releases from the melt glass. Calculations with a simple convection model were not successful in increasing the peak flux of ${ }^{59} \mathrm{Ni}$ significantly, so this approach was not pursued further during the initial SSM development. 
Comparisons for other tracer radionuclides, as shown in Appendix D, are similar to the three examples presented here.

\subsection{Mass Fluxes for Sorbed Radionuclides}

\subsubsection{Initial Comparisons for Sorbed Radionuclides}

The SSM described in Section 4.2.3 also sampled nine distributions for sorption of $\mathrm{Am}, \mathrm{Ca}, \mathrm{Cs}, \mathrm{Eu}, \mathrm{Np}, \mathrm{Pu}, \mathrm{Sm}, \mathrm{Sr}$, and $\mathrm{U}$ in the fracture linings and nine distributions for sorption of these same radionuclides in the cavity/chimney. These distributions are discrete distributions, depending on the presence or absence of sorbing materials, as explained in Section 4.1.4. These distributions are sampled once during each realization of the SSM, providing a constant value for the $\mathrm{K}_{\mathrm{d}}$ of the various radionuclides in the two different media.

The total number of sampled distributions in the SSM is 20 , based on 2 for the fluxes from the exchange volume and melt glass, 9 for the partition coefficients in the fracture linings, and 9 for the partition coefficients in the cavity/chimney. The total number of realizations for each calculation, 40, was set to twice the number of stochastic (sampled) distributions, a typical rule of thumb for Monte Carlo analyses.

The basic SSM produces reasonable agreement for the isotopes of $\mathrm{U}, \mathrm{Np}$, and $\mathrm{Pu}$. Figures 4-9, 4-10, and 4-11 present the comparisons from the SSM to the process (particle) model for ${ }^{234} \mathrm{U},{ }^{237} \mathrm{~Np}$, and ${ }^{239} \mathrm{Pu}$. There is reasonable agreement for the peak fluxes and for the maximum or $95^{\text {th }}$ percentile releases between the SSM and the particle model. The minimum fluxes after 200 years from the SSM are generally higher than the $5^{\text {th }}$ percentile fluxes from the particle model by an order of magnitude after 200 years.

The isotopes of $\mathrm{U}, \mathrm{Np}$, and $\mathrm{Pu}$ have relatively small partition coefficients. Comparison of isotopes with greater partition coefficients, such as Sm or Am, shows major differences between the process model and the SSM. Figures 4-12 and 4-13 present the comparison of the data, which clearly indicates that the SSM has much greater sorption than the particle model.

In response to the comparisons in Figures 4-12 and 4-13, a series of SSM calculations were performed with zero partition coefficients, with partition coefficients only in the exchange volume, and with partition coefficients only in the pipe pathway. These calculations indicate that sorption in the pipe pathway is the major cause of retardation, with the sorption in the exchange volume (cavity/chimney) being a minor contributor. In addition, the (constant) $\mathrm{K}_{\mathrm{d}}$ in the matrix is often the major contributor to sorption in the pipe pathway. For example, the $K_{d}$ in the matrix for americium is an order of magnitude greater than the $K_{d}$ for Americium in the fracture lining, which is turn is much greater than the retardation ratio in the cavity/chimney (exchange volume). 


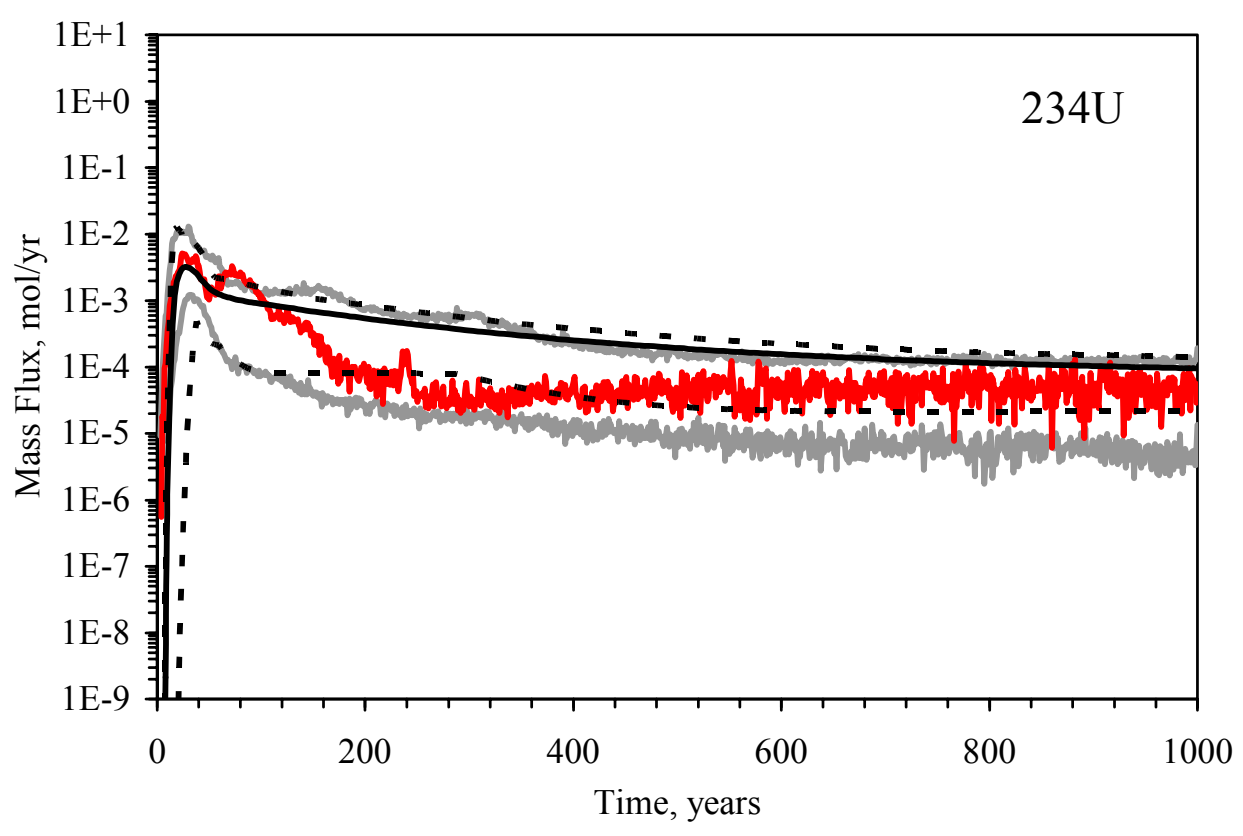

Figure 4-9

Comparison of ${ }^{234} \mathrm{U}$ Mass Fluxes from the Process Model with the SSM.

Particle Model Results: Mean (Red), $5^{\text {th }}$ and $95^{\text {th }}$ Percentiles (Grey);

SSM Results: Mean (Solid Black), Maximum and Minimum (Dashed Black)

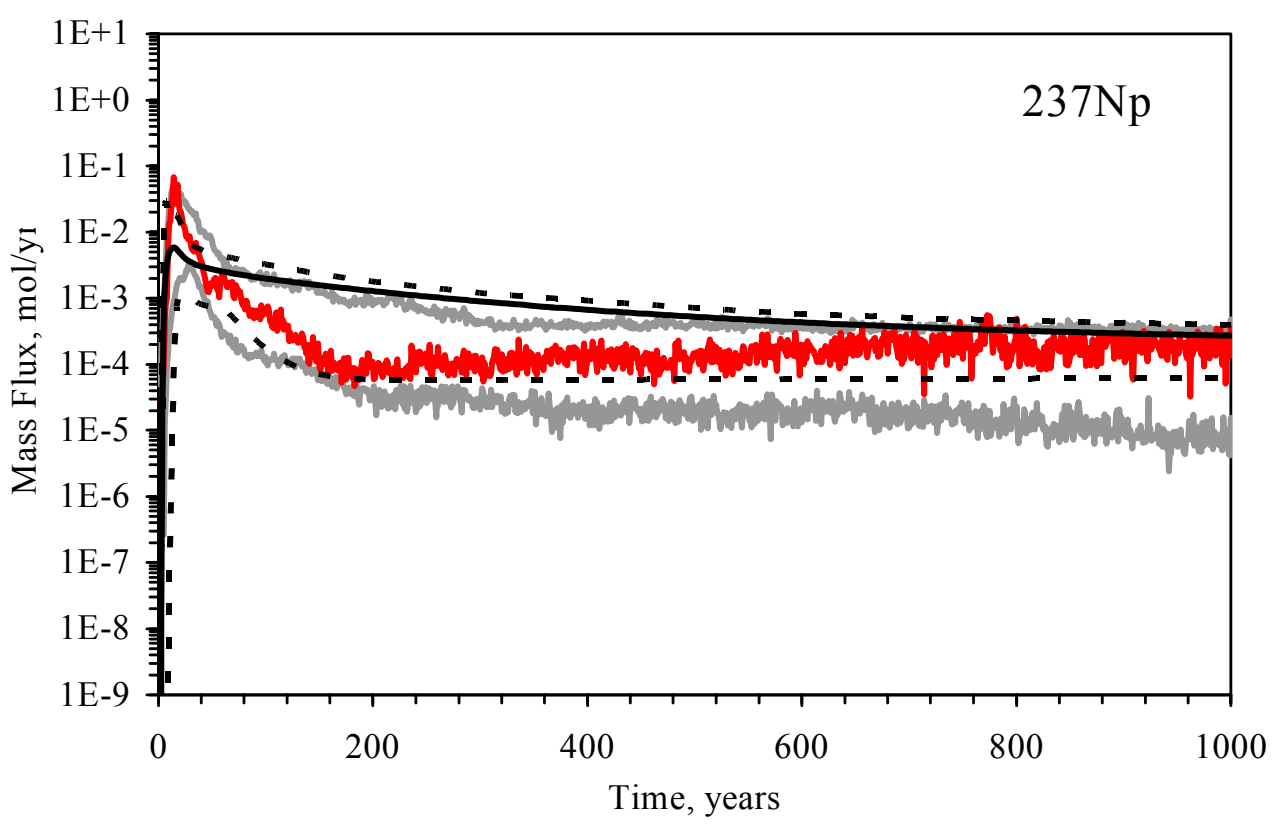

Figure 4-10

Comparison of ${ }^{237} \mathrm{~Np}$ Mass Fluxes from the Process Model with the SSM.

Particle Model Results: Mean (Red), $5^{\text {th }}$ and $95^{\text {th }}$ Percentiles (Grey);

SSM Results: Mean (Solid Black), Maximum and Minimum (Dashed Black) 


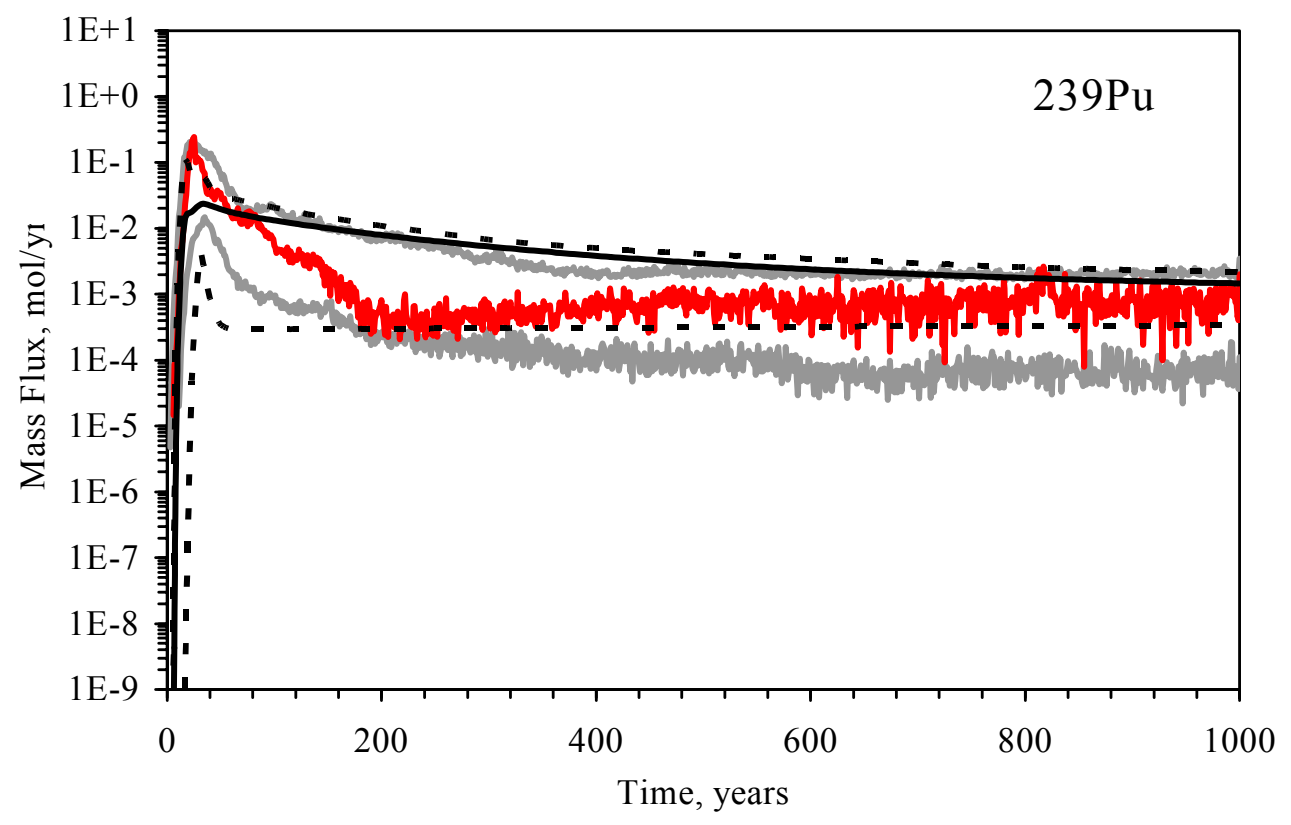

Figure 4-11

Comparison of ${ }^{239} \mathrm{Pu}$ Mass Fluxes from the Process Model with the SSM.

Particle Model Results: Mean (Red), $5^{\text {th }}$ and $95^{\text {th }}$ Percentiles (Grey);

SSM Results: Mean (Solid Black), Maximum and Minimum (Dashed Black)

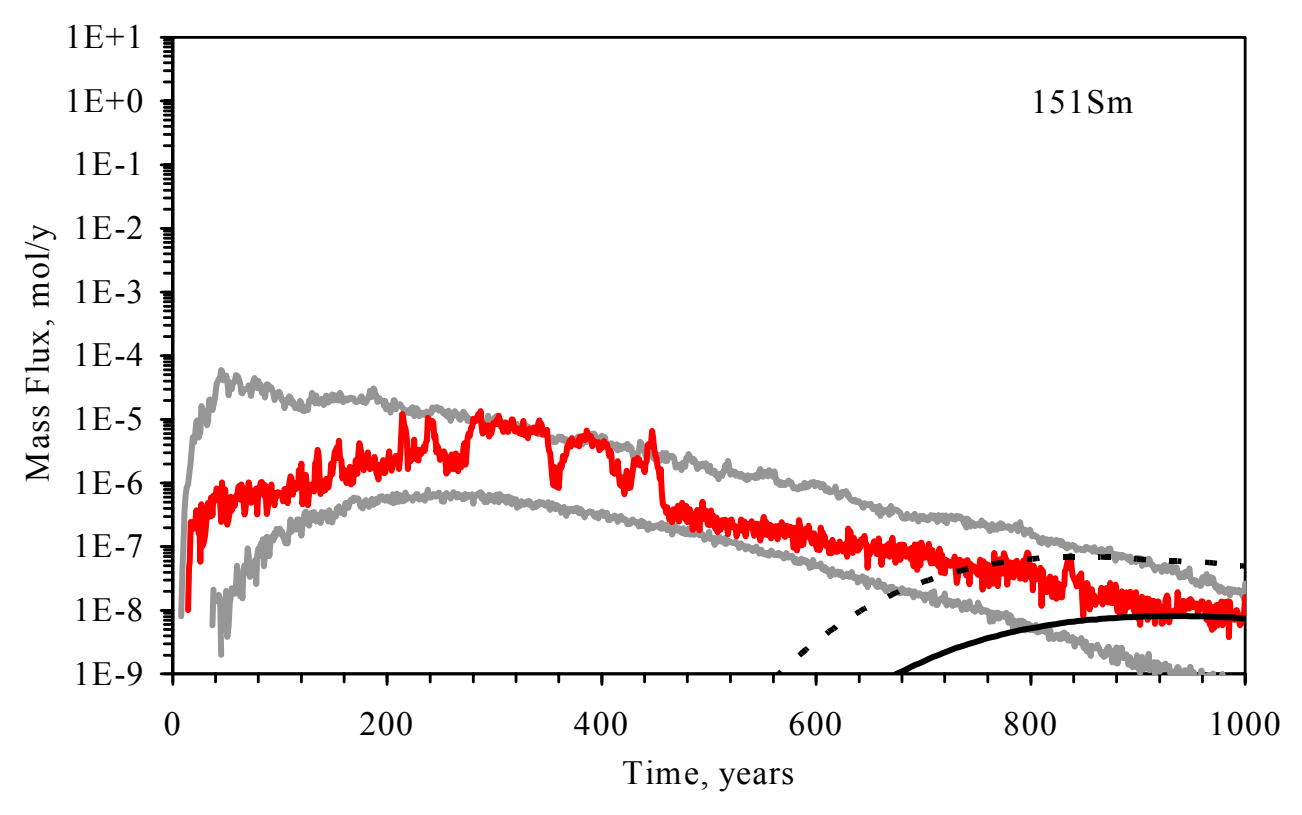

Figure 4-12

Comparison of ${ }^{151} \mathrm{Sm}$ Mass Fluxes from the Process Model with the SSM.

Particle Model Results: Mean (Red), $5^{\text {th }}$ and $95^{\text {th }}$ Percentiles (Grey);

SSM Results: Mean (Solid Black), Maximum (Dashed Black); Minimum Does Not Appear on This Scale 


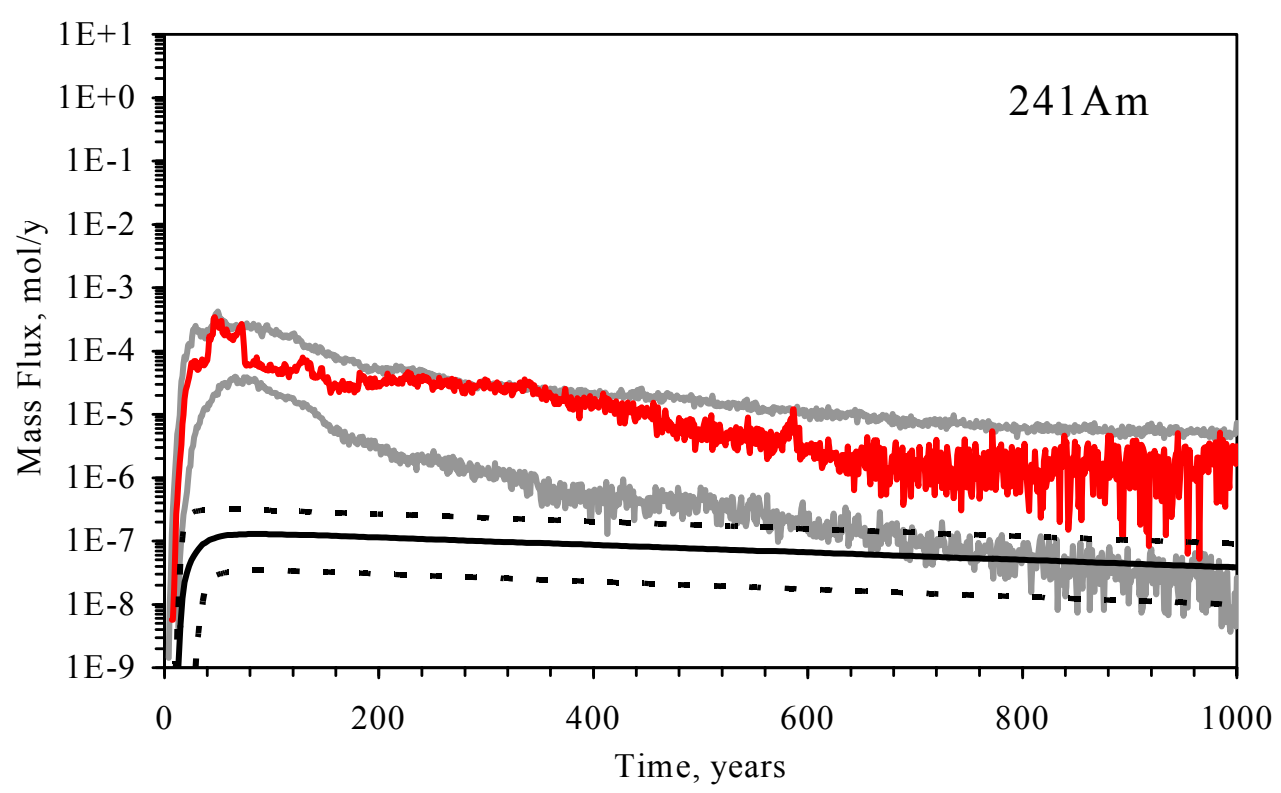

Figure 4-13

Comparison of ${ }^{151} \mathrm{Am}$ Mass Fluxes from the Process Model with the SSM.

Particle Model Results: Mean (Red), $5^{\text {th }}$ And $95^{\text {th }}$ Percentiles (Grey);

SSM Results: Mean (Solid Black), Maximum and Minimum (Dashed Black)

The excess retardation in the pipe pathway may be related to the use of a single pipe pathway in the SSM. The process model has multiple pathways from the source region to the release boundary. The effective flow area for the fast transport pathways in the process model is probably much less than the full area of the exchange volume, as represented in the SSM. A smaller effective flow area provides less mass of sorbing minerals along the fast transport pathways in the process model than in the single, large pipe pathway for the SSM, resulting in less sorption. Multiple pathways with longer travel times would also explain the broader range of mass fluxes from the process model, as demonstrated by the comparisons in Figures 4-9 through 4-11.

As a first approximation to the reduced sorption observed in the process model, the fracture spacing in the near-field rock was reduced from 8 per meter to 1.5 per meter in the SSM. The focus is on the near-field rock because the numerical testing indicated that sorption in the pipe pathway provides the major contribution to sorption. Figures 4-14 and 4-15 present the comparison of results for ${ }^{151} \mathrm{Sm}$ and ${ }^{241} \mathrm{Am}$ with 1.5 fractures per meter.

A fracture spacing of 1.5 per meter (as opposed to 8 per meter) produces substantial improvements in the agreement between the process model and the SSM for Sm and Am. These computational results (Figures 4-11 through 4-15) confirm that the comparison between the process model and the SSM would improve with less sorption. A full set of comparisons for the sorbed radionuclides with a fracture spacing of 1.5 per meter is presented in Appendix D. The general agreement demonstrated in Appendix D is satisfactory to good, with the exception 


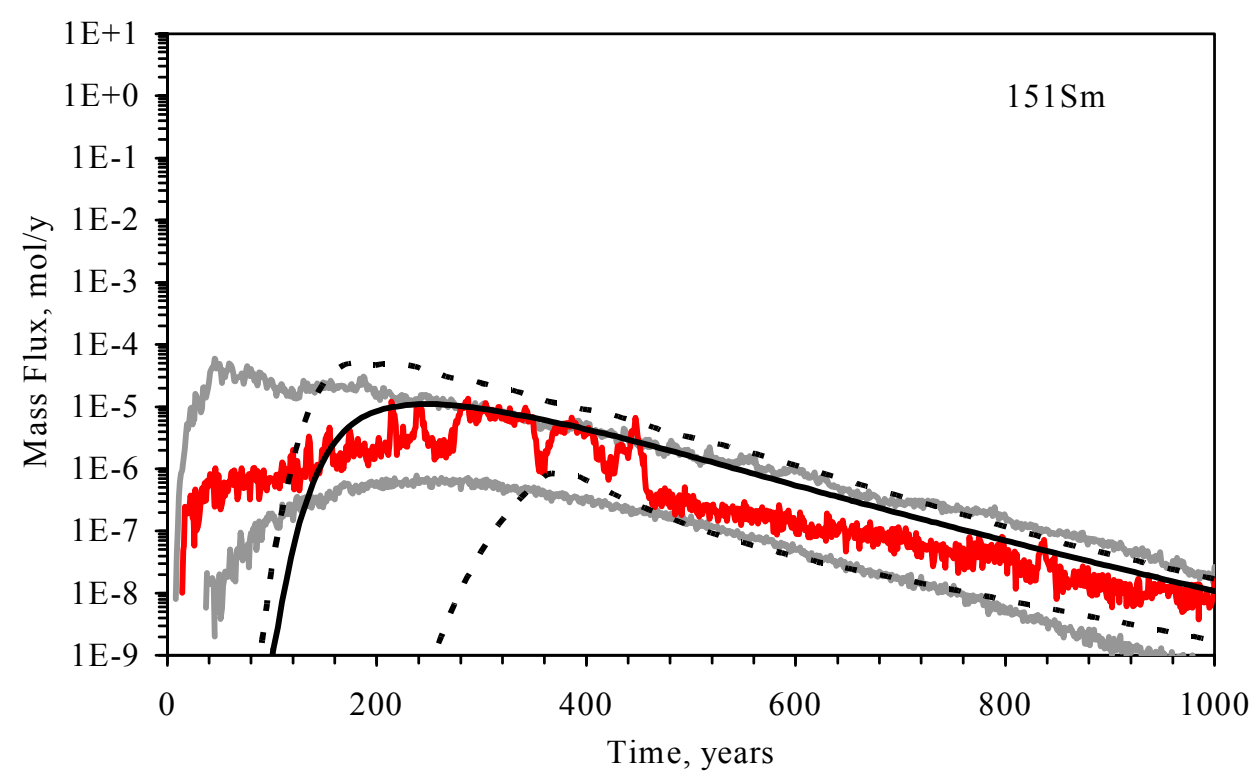

Figure 4-14

Comparison of ${ }^{151} \mathrm{Sm}$ Mass Fluxes from the Process Model with the SSM.

Fracture Spacing of 1.5 per meter. Particle Model Results: Mean (Red), $5^{\text {th }}$ and $95^{\text {th }}$ Percentiles (Grey); SSM Results: Mean (Solid Black), Maximum (Dashed Black); Minimum Does Not Appear on this Scale

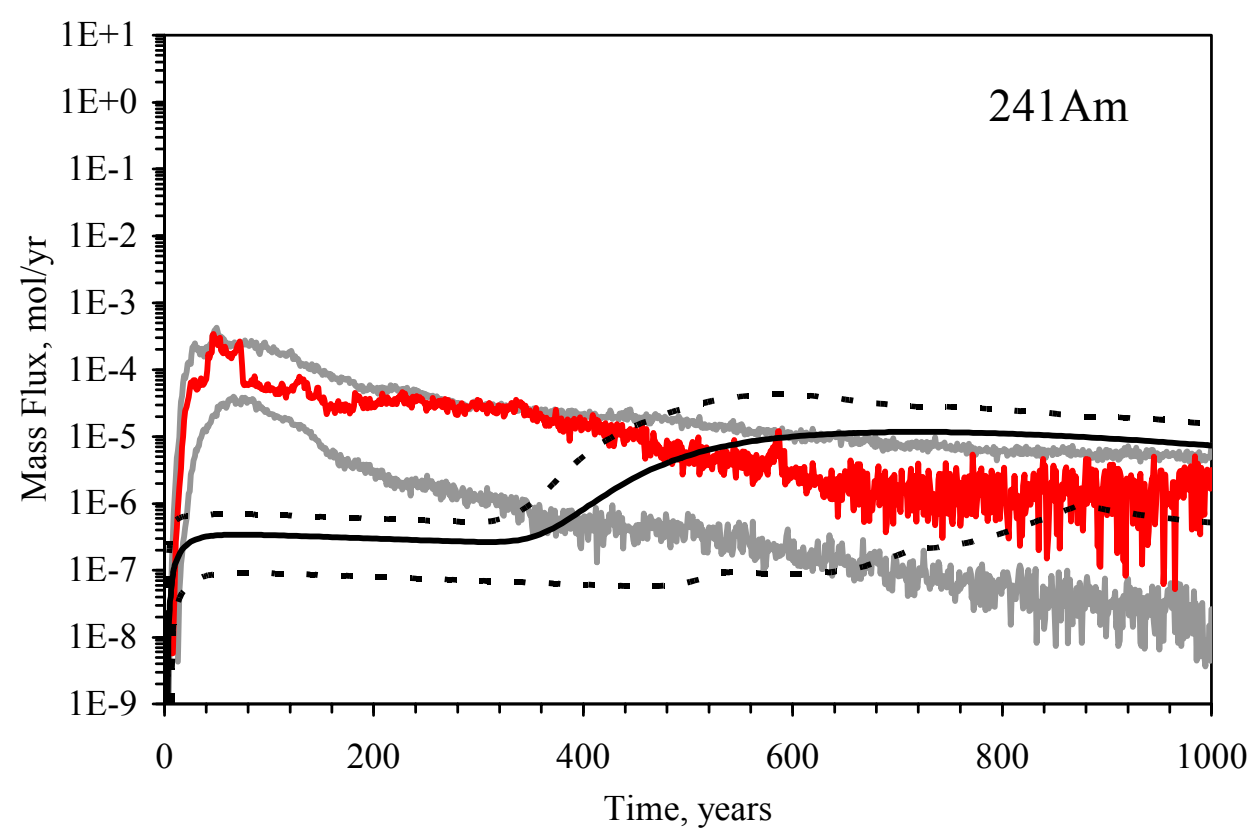

Figure 4-15

Comparison of ${ }^{241} \mathrm{Am}$ Mass Fluxes from the Process Model with the SSM.

Fracture Density of 1.5 per meter. Particle Model Results: Mean (Red), $5^{\text {th }}$ and $95^{\text {th }}$ Percentiles (Grey); SSM Results: Mean (Solid Black), Maximum (Dashed Black); Minimum Does Not Appear on This Scale 
of ${ }^{241} \mathrm{Am}$. The discrepancy for Am and Sm are likely caused by the use of discrete distributions for the retardation ratios. As noted in Section 4.1.4, the discrete distributions result in a bimodal behavior for the partition coefficients. This bimodal behavior means that the SSM transport calculations are sampling the extremes of the $K_{d}$ values, rather than the mid-range of effective $K_{d}$ values that would likely occur with the three-dimensional, spatial distribution for the particle code. In other words, partition coefficients that are appropriate for a three-dimensional spatial distribution will tend to average out the differences in the sampled $\mathrm{K}_{\mathrm{d}}$ values, while the SSM picks only a single value for each realization.

\subsection{Recommendations}

Based on the comparisons reported in Section 4.3, there are two modifications to the SSM that would improve its comparison with the CHESHIRE numerical process model HST. The first is to divide the single transport pipe in the SSM into multiple pipes with a range of travel times and fluxes. Slower pathways will help to improve the late-time comparisons for tracer radionuclides such as ${ }^{14} \mathrm{C}$, where the SSM cannot duplicate the $95^{\text {th }}$ percentile of releases from the particle code. The second modification is to adjust the discrete distribution for retardation ratios to better represent the mid-range of values that are likely to be sampled by the spatial variability in the particle code. 


\section{Unclassified Hydrologic Source Term Calculation Procedure}

Other underground tests in Areas 19 and 20 have features, such as their radionuclide source term, that are not represented in the SSM described in Section 4.0. The total inventory of radionuclides associated with each test is referred to as the radiologic source term. The subsequent release of these radionuclides over time is referred to as the hydrologic source term (HST). The uncertainties that should be considered in computing the unclassified HST with the SSM are discussed in this section, along with statistical distributions that represent such uncertainties. The general uncertainties include radionuclide inventory, radionuclide partitioning in the test cavity and exchange volume, test-cavity geometry, test cavity properties, and far-field hydraulic and transport parameters. Overall, the purpose of the SSM is to represent major uncertainties in the transport of radionuclides from underground tests, not to use probabilistic methods as a surrogate for deterministic variability (e.g., different burial depths) across tests. The planned application of the SSM to the Pahute Mesa CAU transport analysis is described.

As its name implies, the SSM is a simplification of very complex processes that is necessary to estimate the Pahute Mesa test HSTs with reasonable computational effort and time. The SSM does not explicitly model spatially-variable parameters within either stream tube or the cavity, and Goldsim ${ }^{\circledR}$ has only a limited ability in this regard. Exhaustive implementation of such a feature defeats the purpose of the abstraction approach used within the SSM. The SSM also does not simulate convection cells formed (as discussed in Section 4.0) by test heat; again, such a feature is best generated by a detailed process model, which can provide insight into how the complex process can be simplified. Finally, the SSM does not directly include colloid-facilitated transport. Colloid enhanced transport will be represented by adjusting the retardation of species subject to colloid-facilitated transport.

Finally, in the SSM the radionuclides move through the aquifer toward an arbitrarily defined boundary which is envisioned as the location where the source model intersects the larger-scale model. For the SSM simulations, the boundary is assumed to be 305 meters away from the center of the cavity. This assumption may be revised to reflect the actual PM CAU model mesh. 


\subsection{Radionuclide Inventory Uncertainty}

Table 5-1 is a list of 43 radionuclides reported for Areas 19 and 20, and the total inventory of each radionuclide for each area (Bowen et al., 2001). Each of these radionuclides will be individually considered within the inventory for the SSM.

Further discussion of these radionuclides, their total inventory, and their partitioning is provided in this section. Treatment of uncertainty in these quantities is also discussed.

The total (initial) amount of each radionuclide in Table 5-1 is presented separately for Areas 19 and 20. The total inventory number of atoms of each radionuclide is taken directly from Bowen et al. (2001). The values for moles and grams are calculated as indicated in the table footnotes. The total inventory in Table 5-1 must be divided among all the tests in an area (either 19 or 20) in order to provide an unclassified average source term for each specific test.

The total mass of radionuclide $\mathrm{j}\left(\mathrm{MT}_{\mathrm{j}}\right)$ for any specific underground nuclear test, is classified information and not available for analysis. An estimate for $\mathrm{MT}_{\mathrm{j}}$ for each underground test will be made from the total inventory data in Bowen et al. (2001) as the average of all the tests in Area 19 or Area 20, as appropriate. The equation for $\mathrm{MT}_{\mathrm{j}}$ for Areas 19 is given by:

$$
\mathrm{MT}_{\mathrm{j}}\left(\text { Area 19) }=\mathrm{MT}_{\text {all }}(\text { Area 19) } / \mathrm{Nt}(\text { Area 19) }\right.
$$

where:

$\mathrm{MT}_{\text {all }}($ Area 19) $=$ Total radionuclide inventory in Area 19

$\mathrm{MT}_{\mathrm{j}}($ Area 19) $=$ Averaged radionuclide inventory for any test in Area 19

$\mathrm{Nt}=$ Total number of tests in Area 19

The same equation is used for Area 20, where the total inventory and total number of tests are specific to Area 20.

The number of tests in each area is from the published list of "United States Nuclear Tests, July 1945 through September 1992" (DOE/NV, 2000). The number of underground nuclear tests conducted in Area 19 is 36, and 49 in Area 20.

The total inventory is subject to some uncertainty as described by Bowen et al. (2001) as shown in Table 5-2. Previous modeling analysis has shown that source term uncertainty dominates all other terms for near-field response (DOE/NV, 1997b). Thus, the inventory uncertainty must be accounted for in the HST. This will be accomplished by defining a uniform distribution that represents a multiplicative factor defining the range of inventory uncertainty for the radionuclide types, as shown in Table 5-2. When a radionuclide is present in more than one radionuclide group category its inventory will be sampled from the category with the largest uncertainty. During each realization of the HST, the range factor for each radionuclide will be sampled and multiplied by the initial radionuclide mass shown in Table 5-1 to incorporate inventory uncertainty directly into the HST. 
Table 5-1

Total and Average Radionuclide Inventory for Areas 19 and 20 of the Nevada Test Site (Page 1 of 2)

\begin{tabular}{|c|c|c|c|c|c|c|c|c|c|}
\hline \multirow{2}{*}{ Radionuclide } & \multirow{2}{*}{$\begin{array}{l}\text { Atomic } \\
\text { Weight }\end{array}$} & \multicolumn{6}{|c|}{ Total Inventory } & \multicolumn{2}{|c|}{ Average Inventory } \\
\hline & & $\begin{array}{l}\text { Area } 19 \\
\text { (Atoms) }^{a}\end{array}$ & $\begin{array}{c}\text { Area } 20 \\
\text { (Atoms) }^{\mathrm{a}}\end{array}$ & $\begin{array}{l}\text { Area } 19 \\
\text { (Moles) }^{\mathrm{b}}\end{array}$ & $\begin{array}{l}\text { Area } 20 \\
\text { (Moles) }^{b}\end{array}$ & $\begin{array}{c}\text { Area } 19 \\
\text { (Grams) }^{\mathrm{C}}\end{array}$ & $\begin{array}{c}\text { Area } 20 \\
\text { (Grams) }^{\mathrm{C}}\end{array}$ & $\begin{array}{c}\text { Area } 19 \\
\text { Inventory }^{\mathrm{d}}\end{array}$ & $\begin{array}{c}\text { Area } 20 \\
\text { Inventory }\end{array}$ \\
\hline${ }^{3} \mathrm{H}$ & 3.01605 & $3.689 \mathrm{E}+26$ & $1.225 \mathrm{E}+27$ & $6.13 E+02$ & $2.03 E+03$ & $1.85 \mathrm{E}+03$ & $6.14 \mathrm{E}+03$ & $4.87 \mathrm{E}+01$ & $1.31 \mathrm{E}+02$ \\
\hline${ }^{14} \mathrm{C}$ & 14.0032 & $2.111 \mathrm{E}+24$ & $4.518 \mathrm{E}+24$ & $3.51 \mathrm{E}+00$ & $7.50 \mathrm{E}+00$ & $4.91 \mathrm{E}+01$ & $1.05 E+02$ & $1.29 \mathrm{E}+00$ & $2.23 \mathrm{E}+00$ \\
\hline${ }^{26} \mathrm{Al}$ & 25.9869 & $1.073 E+21$ & $1.001 \mathrm{E}+22$ & 1.78E-03 & $1.66 \mathrm{E}-02$ & 4.63E-02 & 4.32E-01 & $1.22 \mathrm{E}-03$ & $9.19 \mathrm{E}-03$ \\
\hline${ }^{36} \mathrm{Cl}$ & 35.9683 & $4.618 \mathrm{E}+25$ & $7.973 E+25$ & $7.67 \mathrm{E}+01$ & $1.32 \mathrm{E}+02$ & $2.76 \mathrm{E}+03$ & $4.76 \mathrm{E}+03$ & $7.26 \mathrm{E}+01$ & $1.01 \mathrm{E}+02$ \\
\hline${ }^{39} \mathrm{Ar}$ & 38.9643 & $2.899 \mathrm{E}+23$ & $5.652 E+23$ & $4.81 \mathrm{E}-01$ & $9.39 \mathrm{E}-01$ & $1.88 \mathrm{E}+01$ & $3.66 \mathrm{E}+01$ & 4.95E-01 & $7.79 \mathrm{E}-01$ \\
\hline${ }^{40} \mathrm{~K}$ & 39.964 & $3.398 \mathrm{E}+29$ & $6.783 E+29$ & $5.64 \mathrm{E}+05$ & $1.13 E+06$ & $2.25 \mathrm{E}+07$ & $4.50 \mathrm{E}+07$ & $5.92 \mathrm{E}+05$ & $9.57 \mathrm{E}+05$ \\
\hline${ }^{41} \mathrm{Ca}$ & 40.9623 & $8.763 E+25$ & $2.208 \mathrm{E}+26$ & $1.46 \mathrm{E}+02$ & $3.67 E+02$ & $5.96 \mathrm{E}+03$ & $1.50 E+04$ & $1.57 \mathrm{E}+02$ & $3.19 \mathrm{E}+02$ \\
\hline${ }^{59} \mathrm{Ni}$ & 58.9343 & $2.043 E+24$ & $3.810 \mathrm{E}+24$ & $3.39 E+00$ & $6.33 \mathrm{E}+00$ & $2.00 \mathrm{E}+02$ & $3.73 E+02$ & $5.26 \mathrm{E}+00$ & $7.94 \mathrm{E}+00$ \\
\hline${ }^{63} \mathrm{Ni}$ & 62.9297 & $2.904 \mathrm{E}+23$ & $5.266 \mathrm{E}+23$ & 4.82E-01 & 8.74E-01 & $3.03 E+01$ & $5.50 E+01$ & 7.97E-01 & $1.17 \mathrm{E}+00$ \\
\hline${ }^{85} \mathrm{Kr}$ & 84.9124 & $9.028 \mathrm{E}+23$ & $1.034 \mathrm{E}+24$ & $1.63 E+00$ & $1.72 \mathrm{E}+00$ & $1.39 \mathrm{E}+02$ & $1.46 \mathrm{E}+02$ & $3.66 \mathrm{E}+00$ & $3.11 \mathrm{E}+00$ \\
\hline${ }^{90} \mathrm{Sr}$ & 89.9073 & $2.814 \mathrm{E}+25$ & $3.314 \mathrm{E}+25$ & 4.67E+01 & $5.50 \mathrm{E}+01$ & $4.20 \mathrm{E}+03$ & $4.95 E+03$ & $1.11 \mathrm{E}+02$ & $1.05 E+02$ \\
\hline${ }^{93} \mathrm{Zr}$ & 92.9061 & $4.767 \mathrm{E}+25$ & $5.993 E+23$ & $7.92 E+01$ & $9.95 \mathrm{E}-01$ & $7.35 \mathrm{E}+03$ & $9.25 E+01$ & $1.93 \mathrm{E}+02$ & $1.97 \mathrm{E}+00$ \\
\hline${ }^{93 m_{\mathrm{Nb}}}$ & 92.906 & $8.053 E+22$ & $1.383 E+23$ & 1.34E-01 & 2.30E-01 & $1.24 \mathrm{E}+01$ & $2.13 E+01$ & 3.26E-01 & 4.53E-01 \\
\hline${ }^{94} \mathrm{Nb}$ & 93.907 & $2.674 \mathrm{E}+24$ & $3.319 \mathrm{E}+24$ & $4.44 \mathrm{E}+00$ & $5.51 \mathrm{E}+00$ & 4.17E+02 & $5.18 \mathrm{E}+02$ & $1.10 \mathrm{E}+01$ & $1.10 \mathrm{E}+01$ \\
\hline${ }^{99} \mathrm{Tc}$ & 98.9064 & $4.821 \mathrm{E}+25$ & $6.394 \mathrm{E}+25$ & $8.01 \mathrm{E}+01$ & $1.06 \mathrm{E}+02$ & $7.92 \mathrm{E}+03$ & $1.05 \mathrm{E}+04$ & $2.08 \mathrm{E}+02$ & $2.23 \mathrm{E}+02$ \\
\hline${ }^{107} \mathrm{Pd}$ & 106.905 & $6.523 E+24$ & $1.097 \mathrm{E}+25$ & $1.08 \mathrm{E}+01$ & $1.82 \mathrm{E}+01$ & $1.16 \mathrm{E}+03$ & $1.95 E+03$ & $3.05 E+01$ & $4.15 \mathrm{E}+01$ \\
\hline${ }^{113 m} \mathrm{Cd}$ & 112.905 & $1.192 \mathrm{E}+22$ & $1.774 \mathrm{E}+22$ & 1.98E-02 & $2.95 \mathrm{E}-02$ & $2.23 E+00$ & $3.33 E+00$ & $5.87 \mathrm{E}-02$ & 7.09E-02 \\
\hline${ }^{121 m_{S n}}$ & 120.904 & $1.651 \mathrm{E}+23$ & $2.470 E+23$ & $2.74 \mathrm{E}-01$ & $4.10 \mathrm{E}-01$ & $3.31 \mathrm{E}+01$ & $4.96 \mathrm{E}+01$ & $8.71 \mathrm{E}-01$ & $1.06 \mathrm{E}+00$ \\
\hline${ }^{126} \mathrm{Sn}$ & 125.904 & $3.405 E+24$ & $5.002 \mathrm{E}+24$ & $5.65 \mathrm{E}+00$ & $8.31 \mathrm{E}+00$ & $7.12 \mathrm{E}+02$ & $1.05 E+03$ & $1.87 \mathrm{E}+01$ & $2.23 \mathrm{E}+01$ \\
\hline $129 \mathrm{I}$ & 128.905 & $1.098 \mathrm{E}+25$ & $1.480 \mathrm{E}+25$ & $1.82 \mathrm{E}+01$ & $2.46 \mathrm{E}+01$ & $2.35 \mathrm{E}+03$ & $3.17 \mathrm{E}+03$ & $6.18 \mathrm{E}+01$ & $6.74 \mathrm{E}+01$ \\
\hline${ }^{135} \mathrm{Cs}$ & 134.906 & $5.397 \mathrm{E}+25$ & $7.120 \mathrm{E}+25$ & $8.96 \mathrm{E}+01$ & $1.18 \mathrm{E}+02$ & $1.21 \mathrm{E}+04$ & $1.59 \mathrm{E}+04$ & $3.18 \mathrm{E}+02$ & $3.38 \mathrm{E}+02$ \\
\hline${ }^{137} \mathrm{Cs}$ & 136.907 & $3.531 \mathrm{E}+25$ & $4.537 \mathrm{E}+25$ & $5.86 \mathrm{E}+01$ & $7.53 E+01$ & $8.03 E+03$ & $1.03 E+04$ & $2.11 \mathrm{E}+02$ & 2.19E+02 \\
\hline${ }^{151} \mathrm{Sm}$ & 150.92 & $3.498 \mathrm{E}+24$ & $5.409 \mathrm{E}+24$ & $5.81 \mathrm{E}+00$ & $8.98 \mathrm{E}+00$ & $8.77 \mathrm{E}+02$ & $1.36 \mathrm{E}+03$ & $2.31 \mathrm{E}+01$ & $2.89 \mathrm{E}+01$ \\
\hline${ }^{150} \mathrm{Eu}$ & 149.92 & $4.733 E+21$ & $6.483 \mathrm{E}+22$ & 7.86E-03 & $1.08 \mathrm{E}-01$ & $1.18 \mathrm{E}+00$ & $1.61 \mathrm{E}+01$ & $3.11 \mathrm{E}-02$ & $3.43 \mathrm{E}-01$ \\
\hline${ }^{152} \mathrm{Eu}$ & 151.922 & $2.626 \mathrm{E}+23$ & $6.774 \mathrm{E}+23$ & 4.36E-01 & $1.12 \mathrm{E}+00$ & $6.62 \mathrm{E}+01$ & $1.71 \mathrm{E}+02$ & $1.74 \mathrm{E}+00$ & $3.64 \mathrm{E}+0$ \\
\hline${ }^{154} \mathrm{Eu}$ & 153.923 & $1.028 \mathrm{E}+23$ & $1.921 \mathrm{E}+23$ & 1.71E-01 & 3.19E-01 & $2.63 \mathrm{E}+01$ & $4.91 \mathrm{E}+01$ & $6.92 \mathrm{E}-01$ & $1.04 \mathrm{E}+00$ \\
\hline $166 m_{\mathrm{Ho}}$ & 165.932 & $6.231 \mathrm{E}+22$ & $5.846 \mathrm{E}+22$ & 1.03E-01 & $9.71 \mathrm{E}-02$ & $1.72 \mathrm{E}+01$ & $1.61 \mathrm{E}+01$ & 4.53E-01 & $3.43 \mathrm{E}-01$ \\
\hline${ }^{232} \mathrm{Th}$ & 232.038 & $2.706 \mathrm{E}+29$ & $5.468 \mathrm{E}+29$ & $4.49 \mathrm{E}+05$ & $9.08 \mathrm{E}+05$ & $1.04 \mathrm{E}+08$ & $2.11 \mathrm{E}+08$ & $2.74 \mathrm{E}+06$ & $4.49 \mathrm{E}+06$ \\
\hline${ }^{232} \mathrm{U}$ & 232.037 & $1.026 \mathrm{E}+22$ & $2.044 \mathrm{E}+22$ & 1.70E-02 & 3.39E-02 & $3.95 \mathrm{E}+00$ & $7.88 \mathrm{E}+00$ & $1.04 \mathrm{E}-01$ & $1.68 \mathrm{E}-01$ \\
\hline${ }^{233} U$ & 233.04 & $1.745 \mathrm{E}+25$ & $3.154 \mathrm{E}+25$ & $2.90 \mathrm{E}+01$ & $5.24 \mathrm{E}+01$ & $6.75 \mathrm{E}+03$ & $1.22 \mathrm{E}+04$ & $1.78 \mathrm{E}+02$ & $2.60 \mathrm{E}+02$ \\
\hline${ }^{234} U$ & 234.041 & $5.888 \mathrm{E}+25$ & $4.885 E+25$ & $9.78 \mathrm{E}+01$ & $8.11 \mathrm{E}+01$ & $2.29 \mathrm{E}+04$ & $1.90 \mathrm{E}+04$ & $6.03 E+02$ & $4.04 \mathrm{E}+02$ \\
\hline${ }^{235} \mathrm{U}$ & 235.044 & $1.533 \mathrm{E}+27$ & $1.592 \mathrm{E}+27$ & $2.55 E+03$ & $2.64 \mathrm{E}+03$ & $5.98 \mathrm{E}+05$ & $6.21 \mathrm{E}+05$ & $1.57 \mathrm{E}+04$ & $1.32 \mathrm{E}+04$ \\
\hline
\end{tabular}


Table 5-1

Total and Average Radionuclide Inventory for Areas 19 and 20 of the Nevada Test Site (Page 2 of 2)

\begin{tabular}{|c|c|c|c|c|c|c|c|c|c|}
\hline \multirow[b]{2}{*}{ Radionuclide } & \multirow{2}{*}{$\begin{array}{l}\text { Atomic } \\
\text { Weight }\end{array}$} & \multicolumn{6}{|c|}{ Total Inventory } & \multicolumn{2}{|c|}{ Average Inventory } \\
\hline & & $\begin{array}{l}\text { Area } 19 \\
\text { (Atoms) }^{a}\end{array}$ & $\begin{array}{c}\text { Area } 20 \\
\text { (Atoms) }^{\mathrm{a}}\end{array}$ & $\begin{array}{l}\text { Area } 19 \\
\text { (Moles) }^{\mathrm{b}}\end{array}$ & $\begin{array}{l}\text { Area } 20 \\
\text { (Moles) }^{\mathrm{b}}\end{array}$ & $\begin{array}{c}\text { Area } 19 \\
\text { (Grams) }^{\mathrm{C}}\end{array}$ & $\begin{array}{c}\text { Area } 20 \\
\text { (Grams) }^{\mathrm{C}}\end{array}$ & $\begin{array}{c}\text { Area } 19 \\
\text { Inventory }^{d}\end{array}$ & $\begin{array}{c}\text { Area } 20 \\
\text { Inventory }\end{array}$ \\
\hline${ }^{236} \mathrm{U}$ & 236.046 & $8.730 \mathrm{E}+25$ & $1.044 \mathrm{E}+26$ & $1.45 E+02$ & $1.73 E+02$ & $3.42 \mathrm{E}+04$ & $4.09 \mathrm{E}+04$ & $9.00 \mathrm{E}+02$ & $8.70 \mathrm{E}+02$ \\
\hline${ }^{238} \mathrm{U}$ & 238.051 & $5.140 \mathrm{E}+28$ & $9.411 \mathrm{E}+28$ & $8.54 \mathrm{E}+04$ & $1.56 \mathrm{E}+05$ & $2.03 \mathrm{E}+07$ & $3.72 \mathrm{E}+07$ & $5.34 \mathrm{E}+05$ & $7.91 \mathrm{E}+05$ \\
\hline${ }^{237} \mathrm{~Np}$ & 237.048 & $4.310 \mathrm{E}+25$ & $8.923 E+25$ & $7.16 \mathrm{E}+01$ & $1.48 \mathrm{E}+02$ & $1.70 \mathrm{E}+04$ & $3.51 \mathrm{E}+04$ & $4.47 \mathrm{E}+02$ & 7.47E+02 \\
\hline${ }^{238} \mathrm{Pu}$ & 238.05 & $4.220 E+23$ & $7.043 E+23$ & 7.01E-01 & 1.17E+00 & $1.67 E+02$ & $2.78 \mathrm{E}+02$ & $4.39 \mathrm{E}+00$ & $5.91 \mathrm{E}+00$ \\
\hline${ }^{239} \mathrm{Pu}$ & 239.052 & $3.119 E+26$ & $5.123 E+26$ & $5.18 \mathrm{E}+02$ & $8.51 \mathrm{E}+02$ & $1.24 \mathrm{E}+05$ & $2.03 E+05$ & $3.26 \mathrm{E}+03$ & $4.32 \mathrm{E}+03$ \\
\hline${ }^{240} \mathrm{Pu}$ & 240.054 & $2.256 \mathrm{E}+25$ & $4.867 \mathrm{E}+25$ & $3.75 \mathrm{E}+01$ & $8.08 \mathrm{E}+01$ & $8.99 E+03$ & $1.94 \mathrm{E}+04$ & $2.37 \mathrm{E}+02$ & $4.13 E+02$ \\
\hline${ }^{241} \mathrm{Pu}$ & 241.057 & $7.145 \mathrm{E}+23$ & $1.686 \mathrm{E}+24$ & $1.19 E+00$ & $2.80 \mathrm{E}+00$ & $2.86 \mathrm{E}+02$ & $6.75 \mathrm{E}+02$ & $7.53 \mathrm{E}+00$ & $1.44 \mathrm{E}+01$ \\
\hline${ }^{242} \mathrm{Pu}$ & 242.059 & $8.637 E+23$ & $1.440 \mathrm{E}+24$ & $1.43 \mathrm{E}+00$ & $2.39 \mathrm{E}+00$ & $3.47 \mathrm{E}+02$ & $5.79 \mathrm{E}+02$ & $9.13 E+00$ & $1.23 \mathrm{E}+01$ \\
\hline${ }^{241} \mathrm{Am}$ & 241.057 & $9.468 \mathrm{E}+23$ & $2.600 \mathrm{E}+24$ & $1.57 \mathrm{E}+00$ & $4.32 \mathrm{E}+00$ & $3.79 \mathrm{E}+02$ & $1.04 \mathrm{E}+03$ & $9.97 \mathrm{E}+00$ & $2.21 \mathrm{E}+01$ \\
\hline${ }^{243} \mathrm{Am}$ & 243.061 & $1.493 \mathrm{E}+20$ & $2.200 \mathrm{E}+21$ & $2.48 \mathrm{E}-04$ & 3.65E-03 & 6.03E-02 & 8.88E-01 & $1.59 \mathrm{E}-03$ & 1.89E-02 \\
\hline${ }^{244} \mathrm{Cm}$ & 244.063 & $3.629 \mathrm{E}+22$ & $6.700 \mathrm{E}+22$ & $6.03 \mathrm{E}-02$ & 1.11E-01 & $1.47 \mathrm{E}+01$ & $2.72 \mathrm{E}+01$ & 3.87E-01 & $5.79 \mathrm{E}-01$ \\
\hline
\end{tabular}

${ }^{\text {a }}$ Total inventory in atoms from Bowen et al. 2001.

${ }^{\mathrm{b}}$ Total inventory in moles calculated by dividing total inventory in atoms by $6.022 \times 10^{23}$ atoms $/ \mathrm{mole}$

${ }^{\mathrm{c}}$ Total inventory in grams calculated by multiplying total inventory in moles by the atomic weight $(\mathrm{gm} / \mathrm{mole})$

${ }^{d}$ Average radionuclide inventory for any test is calculated by dividing the total inventory in grams by the total number of underground tests for a given area (36 tests in Area 19 and 49 tests in Area 20

\subsection{Radionuclide Source Partitioning Uncertainty}

The partitioning of the radionuclides between glass, rubble, water, and gas is taken from Tompson et al. (2004) and summarized in Table 5-3. For the SSM analysis, the partitioning is further simplified by combining the percentages from rubble, gas, and water into one value designated the exchange volume; the percentage in the glass defines the inventory in the melt glass matrix. The melt glass partitioning is used as it was presented by Tompson et al. (2004).

The partitioning is not known with certainty. As noted in the work of Pawloski et al. (2002), the partition percentages are taken primarily from an IAEA report (IAEA, 1998) describing the distribution of radionuclides underground at the atolls of Mururoa and Fangataufa in the south Pacific Ocean. The extrapolation of the IAEA data to the NTS, and to radionuclides not addressed in the IAEA report (as noted by Pawloski et al., 2002), means that the percentages shown in Table 5-3 are "best estimates." The range of uncertainty itself is unknown, but certain to exist. 
Table 5-2

Estimated Accuracies for Groups of Radionuclides

\begin{tabular}{|c|c|c|c|c|}
\hline $\begin{array}{l}\text { Radionuclide } \\
\text { Group }\end{array}$ & Accuracy & Radionuclides & $\begin{array}{l}\text { Distribution } \\
\text { Type }\end{array}$ & $\begin{array}{l}\text { Range Multiplier for Upper } \\
\text { and Lower Bounds }\end{array}$ \\
\hline Fission Products & $\begin{array}{l}\sim 10 \text { to } 30 \\
\text { percent }\end{array}$ & $\begin{array}{c}{ }^{85} \mathrm{Kr},{ }^{90} \mathrm{Sr},{ }^{93} \mathrm{Zr},{ }^{93 \mathrm{~m}} \mathrm{Nb}, \\
{ }^{94} \mathrm{Nb},{ }^{99} \mathrm{Tc},{ }^{107} \mathrm{Pd},{ }^{121 \mathrm{~m}} \mathrm{Sn}, \\
{ }^{126} \mathrm{Sn},{ }^{129},{ }_{1}^{135} \cdot{ }^{135},{ }^{137} \mathrm{Cs}, \\
{ }^{151} \mathrm{Sm},{ }^{166 m}{ }_{\mathrm{Ho}}{ }^{39}{ }^{63},{ }^{59} \mathrm{Ni}, \\
{ }_{\mathrm{Ni},}{ }^{113 \mathrm{~m}} \mathrm{Cd}\end{array}$ & Uniform & $0.7-1.3$ \\
\hline $\begin{array}{l}\text { Unspent Fuel } \\
\text { Materials }\end{array}$ & $\begin{array}{l}\sim 20 \text { percent } \\
\text { or better }\end{array}$ & $\begin{array}{l}{ }^{232} \mathrm{Th},{ }^{232} \mathrm{U},{ }^{233} \mathrm{U},{ }^{234} \mathrm{U}, \\
{ }^{235} \mathrm{U},{ }^{236} \mathrm{U},{ }^{238} \mathrm{U},{ }^{238} \mathrm{Pu}, \\
{ }^{239} \mathrm{Pu}{ }^{240} \mathrm{Pu},{ }^{241} \mathrm{Pu},{ }^{242} \mathrm{Pu}, \\
{ }^{241} \mathrm{Am},{ }^{243} \mathrm{Am},{ }^{244} \mathrm{Cm}\end{array}$ & Uniform & $0.8-1.2$ \\
\hline $\begin{array}{l}\text { Fuel Activation } \\
\text { Products }\end{array}$ & $\begin{array}{l}\sim 50 \text { percent } \\
\text { or better }\end{array}$ & ${ }^{233} \mathrm{U},{ }^{238} \mathrm{Pu},{ }^{239} \mathrm{Pu},{ }^{237} \mathrm{~Np}$ & Uniform & $0.5-1.5$ \\
\hline Residual Tritium & $\begin{array}{l}\sim 300 \\
\text { percent or } \\
\text { better }\end{array}$ & ${ }^{3} \mathrm{H}$ & Uniform & $0.33-3$ \\
\hline $\begin{array}{l}\text { Activation } \\
\text { Products }\end{array}$ & $\begin{array}{c}\sim \text { a factor of } \\
10\end{array}$ & 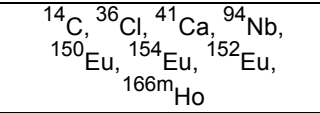 & Uniform & $0.1-10$ \\
\hline
\end{tabular}

Source: Bowen et al., 2001

${ }^{\mathrm{a}}$ Range based on maximum percent uncertainty.

To account for this uncertainty, the percentage of radionuclide partitioned in the melt glass will be allowed to vary according to Table 5-4. The corresponding exchange volume percentage was calculated as 100 percent minus the melt glass percentage. The range of values for each partitioning class are approximate and are used to assign additional variability to the calculations. Each of these distributions is sampled once per realization and the resulting value defines the initial distribution of radionuclides among the exchange volume and the melt glass. The ranges in Table 5-4 are judgement and sensitivity analysis will be conducted with the SSM to further assess the importance of this uncertainty.

\subsection{Uncertainty in Hydrologic Setting of Tests}

In this section, a strategy for categorizing the underground tests on Pahute Mesa is presented (Pawloski, 2004). This strategy is used as a way to simplify the creation and application of the hydrologic source term for the CAU model.

A key conclusion of their study was the division of the test locations on the basis of hydrostratigraphic unit (HSU). Two grouping were considered, aquifers and confining units. A third group, high yield tests, was also identified.

Pawloski (2004) separated this group because of the large yields and, thus, larger cavity sizes and the generally greater depth of these tests compared with most of the other tests on Pahute Mesa. Tables 5-5 and 5-6 summarize Pahute Mesa tests classified by HSU type. In addition, more detailed information related to these tests are provided in Tables 3-2 and 3-3. 
Table 5-3

Summary of Radionuclides with Total Inventory (Curies) and Partitioning Percentages (Page 1 of 2)

\begin{tabular}{|c|c|c|c|c|c|c|c|}
\hline \multirow{2}{*}{ Radionuclide } & \multirow{2}{*}{$\begin{array}{l}\text { Half-Life } \\
\text { (Years) }\end{array}$} & \multicolumn{2}{|c|}{ Radionuclide Amount ${ }^{\mathrm{a}}$ (Curies) } & \multicolumn{4}{|c|}{$\begin{array}{l}\text { Partitioning of Total Inventory } \\
\text { (Percent) }\end{array}$} \\
\hline & & $\begin{array}{l}\text { Pahute Mesa } \\
\text { Area } 19\end{array}$ & $\begin{array}{c}\text { Pahute Mesa } \\
\text { Area } 20\end{array}$ & $\begin{array}{l}\text { Melt } \\
\text { Glass }\end{array}$ & Rubble & Gas & Water \\
\hline${ }^{3} \mathrm{H}$ & $1.23 \mathrm{E}+01$ & $1.778 \mathrm{E}+07$ & $5.903 E+07$ & 0 & 0 & 2 & 98 \\
\hline${ }^{14} \mathrm{C}$ & $5.730 \mathrm{E}+03$ & $2.193 E+02$ & $4.693 E+02$ & 0 & 10 & 80 & 10 \\
\hline${ }^{36} \mathrm{Cl}$ & $3.01 \mathrm{E}+05$ & $9.108 \mathrm{E}+01$ & $1.573 \mathrm{E}+02$ & 50 & 40 & 0 & 10 \\
\hline${ }^{39} \mathrm{Ar}$ & $2.69 \mathrm{E}+02$ & $6.398 \mathrm{E}+02$ & $1.247 \mathrm{E}+03$ & 0 & 10 & 80 & 10 \\
\hline${ }^{41} \mathrm{Ca}$ & $1.03 \mathrm{E}+05$ & $5.050 \mathrm{E}+02$ & $1.273 \mathrm{E}+03$ & 70 & 30 & 0 & 0 \\
\hline${ }^{59} \mathrm{Ni}$ & $7.6 \mathrm{E}+04$ & $1.596 \mathrm{E}+01$ & $2.976 \mathrm{E}+01$ & 95 & 5 & 0 & 0 \\
\hline${ }^{63} \mathrm{Ni}$ & $1.00 \mathrm{E}+02$ & $1.724 \mathrm{E}+03$ & $3.126 \mathrm{E}+03$ & 95 & 5 & 0 & 0 \\
\hline${ }^{85} \mathrm{Kr}$ & $1.070 \mathrm{E}+01$ & $4.981 \mathrm{E}+04$ & $5.706 \mathrm{E}+04$ & 0 & 10 & 80 & 10 \\
\hline${ }^{90} \mathrm{Sr}$ & $2.91 \mathrm{E}+01$ & $5.804 \mathrm{E}+05$ & $6.835 \mathrm{E}+05$ & 40 & 60 & 0 & 0 \\
\hline${ }^{93} \mathrm{Zr}$ & $1.5 \mathrm{E}+06$ & $1.887 \mathrm{E}+01$ & $2.372 \mathrm{E}+01$ & 95 & 5 & 0 & 0 \\
\hline${ }^{93 m} \mathrm{Nb}$ & $1.61 \mathrm{E}+01$ & $2.969 \mathrm{E}+03$ & $5.100 \mathrm{E}+03$ & 95 & 5 & 0 & 0 \\
\hline${ }^{94} \mathrm{Nb}$ & $2.0 \mathrm{E}+04$ & $7.938 \mathrm{E}+01$ & $9.852 \mathrm{E}+01$ & 95 & 5 & 0 & 0 \\
\hline${ }^{99} \mathrm{Tc}$ & $2.13 E+05$ & $1.344 \mathrm{E}+02$ & $1.782 \mathrm{E}+02$ & 80 & 20 & 0 & 0 \\
\hline${ }^{107} \mathrm{Pd}$ & $6.5 \mathrm{E}+06$ & $5.957 \mathrm{E}-01$ & $1.002 \mathrm{E}+00$ & 70 & 30 & 0 & 0 \\
\hline${ }^{121 m_{S n}}$ & $5.5 \mathrm{E}+01$ & $1.782 \mathrm{E}+03$ & $2.667 E+03$ & 60 & 40 & 0 & 0 \\
\hline${ }^{126} \mathrm{Sn}$ & $1 \mathrm{E}+05$ & $8.085 E+00$ & $1.188 \mathrm{E}+01$ & 70 & 30 & 0 & 0 \\
\hline 129 & $1.57 \mathrm{E}+07$ & 4.153E-01 & $5.596 \mathrm{E}-01$ & 50 & 40 & 0 & 10 \\
\hline${ }^{135} \mathrm{Cs}$ & $2.3 E+06$ & $1.393 E+01$ & $1.838 \mathrm{E}+01$ & 20 & 80 & 0 & 0 \\
\hline${ }^{137} \mathrm{Cs}$ & $3.020 \mathrm{E}+01$ & $6.971 \mathrm{E}+05$ & $8.957 \mathrm{E}+05$ & 20 & 80 & 0 & 0 \\
\hline${ }^{151} \mathrm{Sm}$ & $9.0 \mathrm{E}+01$ & $2.307 \mathrm{E}+04$ & $3.568 \mathrm{E}+04$ & 95 & 5 & 0 & 0 \\
\hline${ }^{150} \mathrm{Eu}$ & $3.6 \mathrm{E}+01$ & $7.805 E+01$ & $1.069 \mathrm{E}+03$ & 95 & 5 & 0 & 0 \\
\hline${ }^{152} \mathrm{Eu}$ & $1.350 \mathrm{E}+01$ & $1.151 \mathrm{E}+04$ & $2.970 \mathrm{E}+04$ & 95 & 5 & 0 & 0 \\
\hline${ }^{154} \mathrm{Eu}$ & $8.59 \mathrm{E}+00$ & $7.099 \mathrm{E}+03$ & $1.327 \mathrm{E}+04$ & 95 & 5 & 0 & 0 \\
\hline${ }^{166 m_{\mathrm{Ho}}}$ & $1.2 \mathrm{E}+03$ & $3.083 E+01$ & $2.892 \mathrm{E}+01$ & 95 & 5 & 0 & 0 \\
\hline${ }^{232} \mathrm{U}$ & $7.0 \mathrm{E}+01$ & $8.730 \mathrm{E}+01$ & $1.738 \mathrm{E}+02$ & 90 & 10 & 0 & 0 \\
\hline${ }^{233} U$ & $1.590 \mathrm{E}+05$ & $6.508 \mathrm{E}+01$ & $1.176 \mathrm{E}+02$ & 90 & 10 & 0 & 0 \\
\hline${ }^{234} U$ & $2.46 \mathrm{E}+05$ & $1.421 \mathrm{E}+02$ & $1.179 \mathrm{E}+02$ & 90 & 10 & 0 & 0 \\
\hline${ }^{235} \mathrm{U}$ & $7.04 \mathrm{E}+08$ & $1.293 \mathrm{E}+00$ & $1.343 E+00$ & 90 & 10 & 0 & 0 \\
\hline${ }^{236} U$ & $2.340 \mathrm{E}+07$ & $2.213 \mathrm{E}+00$ & $2.647 E+00$ & 90 & 10 & 0 & 0 \\
\hline${ }^{238} U$ & $4.47 \mathrm{E}+09$ & $6.826 \mathrm{E}+00$ & $1.250 \mathrm{E}+01$ & 90 & 10 & 0 & 0 \\
\hline${ }^{237} \mathrm{~Np}$ & $2.14 \mathrm{E}+06$ & $1.196 \mathrm{E}+01$ & $2.476 \mathrm{E}+01$ & 95 & 5 & 0 & 0 \\
\hline${ }^{238} \mathrm{Pu}$ & $8.77 \mathrm{E}+01$ & $2.857 \mathrm{E}+03$ & $4.768 \mathrm{E}+03$ & 95 & 5 & 0 & 0 \\
\hline
\end{tabular}


Table 5-3

Summary of Radionuclides with Total Inventory (Curies) and Partitioning Percentages (Page 2 of 2)

\begin{tabular}{|c|c|c|c|c|c|c|c|}
\hline \multirow{2}{*}{ Radionuclide } & \multirow{2}{*}{$\begin{array}{l}\text { Half-Life } \\
\text { (Years) }\end{array}$} & \multicolumn{2}{|c|}{ Radionuclide Amount ${ }^{\mathrm{a}}$ (Curies) } & \multicolumn{4}{|c|}{$\begin{array}{l}\text { Partitioning of Total Inventory } \\
\text { (Percent) }\end{array}$} \\
\hline & & $\begin{array}{l}\text { Pahute Mesa } \\
\text { Area } 19\end{array}$ & $\begin{array}{l}\text { Pahute Mesa } \\
\text { Area } 20\end{array}$ & $\begin{array}{l}\text { Melt } \\
\text { Glass }\end{array}$ & Rubble & Gas & Water \\
\hline${ }^{239} \mathrm{Pu}$ & $2.410 \mathrm{E}+04$ & $7.684 \mathrm{E}+03$ & $1.262 \mathrm{E}+04$ & 95 & 5 & 0 & 0 \\
\hline${ }^{240} \mathrm{Pu}$ & $6.56 \mathrm{E}+03$ & $2.041 \mathrm{E}+03$ & $4.405 E+03$ & 95 & 5 & 0 & 0 \\
\hline${ }^{241} \mathrm{Pu}$ & $1.44 \mathrm{E}+01$ & $2.946 \mathrm{E}+04$ & $6.952 \mathrm{E}+04$ & 95 & 5 & 0 & 0 \\
\hline${ }^{241} \mathrm{Am}$ & $4.330 \mathrm{E}+02$ & $1.299 \mathrm{E}+03$ & $3.567 \mathrm{E}+03$ & 95 & 5 & 0 & 0 \\
\hline${ }^{244} \mathrm{Cm}$ & $1.81 \mathrm{E}+01$ & $1.190 \mathrm{E}+03$ & $2.197 \mathrm{E}+03$ & 95 & 5 & 0 & 0 \\
\hline
\end{tabular}

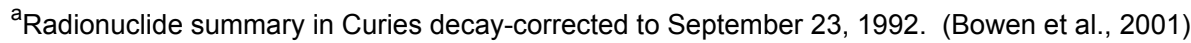

bSource: Tompson et al. (2004)

Table 5-4

Probabilistic Distributions for Melt Glass/Exchange Volume Partitioning Coefficients in Terms of Melt Glass Fraction

\begin{tabular}{||c|c|c|c|c||}
\hline $\begin{array}{c}\text { Statistical } \\
\text { Distribution } \\
\text { Type }\end{array}$ & Lower Limit & $\begin{array}{c}\text { Distribution } \\
\text { Fraction }\end{array}$ & Upper Limit & Radionuclides \\
\hline \hline Uniform & 0.0 & 0.0 & 0.05 & ${ }^{3} \mathrm{H},{ }^{14} \mathrm{C},{ }^{39} \mathrm{Ar},{ }^{85} \mathrm{Kr}$ \\
\hline Uniform & 0.1 & 0.2 & 0.3 & ${ }^{135} \mathrm{Cs},{ }^{137} \mathrm{Cs}$ \\
\hline Uniform & 0.3 & 0.4 & 0.5 & ${ }^{90} \mathrm{Sr}$ \\
\hline Uniform & 0.4 & 0.50 & 0.6 & ${ }^{36} \mathrm{Cl},{ }^{129} \mathrm{I}$ \\
\hline Uniform & 0.5 & 0.60 & 0.7 & ${ }^{121} \mathrm{Sn}$ \\
\hline Uniform & 0.6 & 0.70 & 0.8 & ${ }^{41} \mathrm{Ca},{ }^{107} \mathrm{Pd},{ }^{113} \mathrm{Cd},{ }^{126} \mathrm{Sn}$ \\
\hline Uniform & 0.7 & 0.80 & 0.9 & ${ }^{99} \mathrm{Tc}$ \\
\hline Uniform & 0.85 & 0.90 & 0.95 & ${ }^{232} \mathrm{U},{ }^{233} \mathrm{U},{ }^{234} \mathrm{U},{ }^{235} \mathrm{U},{ }^{236} \mathrm{U},{ }^{238} \mathrm{U}$ \\
\hline Uniform & 0.9 & 0.95 & 1.0 & ${ }^{59} \mathrm{Ni}^{153} \mathrm{Gd},{ }^{150} \mathrm{Eu},{ }^{152} \mathrm{Zr},{ }^{93 \mathrm{~m}} \mathrm{Nb},{ }^{94} \mathrm{Nb},{ }^{151} \mathrm{Sm},{ }^{154} \mathrm{Eu},{ }^{166} \mathrm{Ho},{ }^{237} \mathrm{~Np},{ }^{238} \mathrm{Pu}$, \\
\hline
\end{tabular}

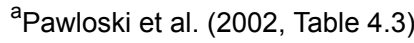


Table 5-5

Underground Shaft Nuclear Tests in Area 19 Classified by HSU Type

\begin{tabular}{|c|c|c|}
\hline Test Name & $\begin{array}{c}\text { Borehole } \\
\text { Name }\end{array}$ & $\begin{array}{l}\text { Overlying } \\
\text { Aquifer Present }\end{array}$ \\
\hline \multicolumn{3}{|c|}{ Aquifers } \\
\hline ALAMO & U19au & \\
\hline JUNCTION & U19bg & \\
\hline CHANCELLOR & U19ad & \\
\hline CYBAR & U19ar & \\
\hline SERPA & U19ai & \\
\hline HOSTA & U19ak & \\
\hline SLED & U19i & \\
\hline TIERRA & U19ac & \\
\hline AMARILLO & U19ay & \\
\hline CHARTREUSE & U19d & \\
\hline STINGER & U19L & \\
\hline PANIR & U19yS & \\
\hline RICKEY & U19c & \\
\hline \multicolumn{3}{|c|}{ Aquifers Large Tests } \\
\hline HALFBEAK & U19b & Yes \\
\hline MAST & U19u & Yes \\
\hline MUENSTER & U19e & Yes \\
\hline INLET & U19f & \\
\hline ESTUARY & U19g & \\
\hline \multicolumn{3}{|c|}{ Confining Units } \\
\hline BEXAR & U19ba & \\
\hline NEBBIOLO & U19ae & \\
\hline SHEEPSHEAD & U19aa & \\
\hline HOUSTON & U19az & \\
\hline LOCKNEY & U19aq & \\
\hline LABQUARK & U19an & \\
\hline KEARSARGE & U19ax & \\
\hline FONDUTTA & U19zS & \\
\hline HARZER & U19aj & \\
\hline TOWANDA & U19ab & \\
\hline BACKBEACH & U19x & \\
\hline SCOTCH & U19aS & Yes \\
\hline \multicolumn{3}{|c|}{ Confining Units - Large Tests } \\
\hline POOL & U19p & \\
\hline ALMENDRO & U19v & \\
\hline CAMEMBERT & U19q & Yes \\
\hline
\end{tabular}


Table 5-6

Underground Shaft Nuclear Tests in Area 20 Classified by HSU Type

\begin{tabular}{|c|c|c|}
\hline Test Name & $\begin{array}{c}\text { Borehole } \\
\text { Name }\end{array}$ & $\begin{array}{c}\text { Overlying } \\
\text { Aquifer Present }\end{array}$ \\
\hline \multicolumn{3}{|c|}{ Aquifers } \\
\hline KERNVILLE & U20ar & \\
\hline CABRA & U20aj & \\
\hline CONTACT & U20aw & \\
\hline EGMONT & U20aL & \\
\hline GOLDSTONE & U20ao & \\
\hline HORNITOS & U20bc & \\
\hline SERENA & U20an & \\
\hline TENABO & U20bb & \\
\hline JEFFERSON & U20ai & \\
\hline CHATEAUGAY & U20t & \\
\hline SALUT & U20ak & \\
\hline COMSTOCK & U20ay & \\
\hline KNICKERBOCKER & U20d & \\
\hline COLWICK & U20ac & \\
\hline MOLBO & U20ag & \\
\hline KAPPELI & U20am & \\
\hline $\mathrm{KASH}$ & U20af & \\
\hline TAFI & U20ae & \\
\hline STILTON & U20p & Yes \\
\hline GIBNE & U20ah & \\
\hline PURSE & U20v & \\
\hline BARNWELL & U20az & \\
\hline BELMONT & U20as & \\
\hline HARDIN & U20av & \\
\hline BODIE & U20ap & \\
\hline MONTELLO & U20bf & \\
\hline HOYA & U20be & \\
\hline REX & U20h(e) & Yes \\
\hline BULLION & U20bd & \\
\hline PEPATO & U20ad & \\
\hline FARM & U20ab & \\
\hline BUTEO & U20a & \\
\hline \multicolumn{3}{|c|}{ Aquifers - Large Tests } \\
\hline PIPKIN & U20b & \\
\hline BOXCAR & U20i & Yes \\
\hline CHESHIRE & U20n & Yes \\
\hline TYBO & U20y & \\
\hline JORUM & U20e & Yes \\
\hline HANDLEY & $\mathrm{U} 20 \mathrm{~m}$ & Yes \\
\hline FONTINA & U20f & Yes \\
\hline COLBY & U20aa & Yes \\
\hline BENHAM & U20c & Yes \\
\hline \multicolumn{3}{|c|}{ Confining Units } \\
\hline DELAMAR & U20at & \\
\hline DARWIN & U20aq & \\
\hline \multicolumn{3}{|c|}{ Confining Units - Large Tests } \\
\hline GREELEY & U20g & Yes \\
\hline KASSERI & U20z & Yes \\
\hline
\end{tabular}


The authors make additional note of the post test formation of a chimney which may allow radionuclides to migrate out of the cavity to overlying aquifers (see Pawloski, 2004 and Wolfsberg et al., 2002). Based on this categorization, underground tests are grouped into the following categories: (1) tests in aquifers, (2) tests in aquifers with overlying aquifers, (3) tests in confining units, and (4) tests in confining units with overlying aquifers.

Underground tests detonated in aquifer units, but without overlying aquifers between the cavity and the water table are the simplest case. In these situations, the groundwater flows through the exchange volume and melt glass. The groundwater will continue to remove radionclides during the entire 1,000-year time period of interest.

Underground tests detonated in aquifers, but with overlying aquifers are treated slightly differently. As Pawloski (2004) and Wolfsberg et al. (2002) have shown, test related heat creates convection cells in the chimneys that can carry radionuclides upward to overlying aquifers. This phenomenon is expected to occur for a period of time up to about 200 years following a test. For the simplified source term, radionuclides are released to all potentially impacted aquifers, weighted on the flux through each aquifer, for a period of 200 years. After 200 years, only the aquifer containing the test cavity will receive a radionuclide flux.

Underground tests detonated in confining units may not be considered as source locations. These locations are assumed to have no pathway to transport radionuclides away from the test within a period of 1,000 years. With no obvious pathway to aquifers, the radionuclides associated with underground tests in confining units may not contribute to any determination of a contaminant boundary.

Underground tests detonated in confining units, but with overlying aquifers will also be considered source locations, but for a limited period of time. When aquifers overlying the test are present, radionuclides will be assumed to migrate up the chimney and out into those aquifers for a period of up to 200 years. After 200 years the heat driven convection is assumed to stop and no further release of radionuclides occurs because the only remaining pathway is through the confining layer adjacent to the underground test.

The strategy on how to incorporate the tests in Categories (2) through (4) into the PM transport model will be developed in the future based on collaboration through the NNSA/NSO Underground Test Area Technical Working Group.

Table 5-7 summarizes the different cases to be considered during the creation of the source term for the CAU model.

\subsection{Test-Cavity Geometry Uncertainty}

The cavity volume is calculated from the maximum announced yield, the bulk overburden density, and the depth of burial (Pawloski, 1999): 
Table 5-7

Summary of HSU Categories for Underground Nuclear Tests

\begin{tabular}{||l|c|c||}
\hline \multicolumn{1}{|c|}{ Test Category } & $\begin{array}{c}\text { Radionuclides Released to } \\
\text { all Aquifer HSUs Above the } \\
\text { Cavity for 200 Years }\end{array}$ & $\begin{array}{c}\text { Radionuclides Released to } \\
\text { the Aquifer HSUs at the } \\
\text { Cavity Depth for 1,000 Years }\end{array}$ \\
\hline \hline Cavity in an Aquifer & $X$ & $X$ \\
\hline Cavity in an Aquifer with Overlying Aquifers & $X$ & $X$ \\
\hline Cavity in a Confining Unit & $X$ \\
\hline Cavity in a Confining Unit with Overlying Aquifers & $R_{C}=\frac{70.2(Y)^{1 / 3}}{\left(\rho_{b} D O B\right)^{1 / 4},}$ \\
\hline
\end{tabular}

where

$R_{C} \quad=$ The cavity radius in meters

$Y=$ The yield in kilotons

$\rho_{b} \quad=$ The bulk density of the overlying rock and soils in $\mathrm{g} / \mathrm{cc}$

$D O B=$ The depth of burst in meters

The yield is not allowed to vary outside the announced range, and all unclassified calculations must be done with the maximum announced yield. Thus, the only way to introduce uncertainty in the cavity volume is via the bulk overburden density or depth of burial. A single value is presented by Pawloski (2004) for depth of burial; no uncertainty is given although some could be assumed to exist from survey or other measurement. Overburden bulk density has some uncertainty associated with it as well. As shown in Section 4.0, the SSM reasonably replicates the CHESHIRE HST process model results as well as its 5 and 95 percent confidence limits without considering any variation in cavity radius. This result is consistent with the process-level calculations for the CHESHIRE test (Pawloski et al., 2002), which also assumed constant values for the cavity volume.

The radius of the exchange volume is a function of the calculated cavity radius and is defined as the product of the calculated cavity radius and a multiplier reflecting the amount of volume around the cavity immediately affected by the underground test and the subsequent radionuclide emplacement:

$$
R_{E V}=M R_{C}
$$

where

$R_{E V} \quad=\quad$ The exchange volume radius in meters

$M \quad=$ The value of the multiplicative factor.

The exchange volume multiplier accounts for the uncertainty in the estimate of the mixing volume outside the test cavity. Due to prompt injection and other mechanisms, it is expected that in some cases, the volume associated with radionuclides will be larger than the exchange volume itself. The probabilistic 
distribution reflecting the uncertainty in the exchange-volume multiplier is shown in Table 5-8.

The mass of the melt glass $\left(\mathrm{M}_{\mathrm{MG}}\right)$ is estimated to be 700 tons per kiloton of yield. To account for the uncertainty associated with this parameter, a range of 700 to 1,300 tons/kilotons (Tompson et al., 1999) will be used in the SSM, as shown in Table 5-8.

Table 5-8

Exchange Volume Probabilistic Parameters

\begin{tabular}{||l|c|c|c|c|c|}
\hline \multicolumn{1}{|c|}{ Parameter } & Distribution & Mean & $\begin{array}{c}\text { Standard } \\
\text { Deviation }\end{array}$ & $\begin{array}{c}\text { Lower } \\
\text { Limit }\end{array}$ & $\begin{array}{c}\text { Upper } \\
\text { Limit }\end{array}$ \\
\hline \hline $\begin{array}{l}\text { Cavity Radius (impacts exchange } \\
\text { volume, cavity volume, and melt } \\
\text { glass volume) }^{\mathrm{a}}\end{array}$ & Truncated Normal & 1.5 & 0.2 & 1.3 & 2.0 \\
\hline Melt Glass Multiplier $^{\mathrm{b}}$ & Uniform & - & - & 700 & 1,300 \\
\hline
\end{tabular}

a Borg et al., 1976

${ }^{\mathrm{b}}$ Tompson et al., 1999

\subsection{Far-Field Flow and Transport Parameters}

Groundwater flow into the vicinity of the test depends on the far-field, or HSU-scale, hydraulic gradient and hydraulic conductivity for Pahute Mesa HSUs. Pawloski (2004) presents the working-point HSU for each Pahute Mesa test, and the Pahute Mesa Hydrologic Data Document (Rehfeldt et al., 2003) presents the expected HSU hydraulic conductivity and standard deviation. Table 5-9 shows the distribution types and parameters for the hydraulic gradient and HSU hydraulic conductivity in which tests were conducted. These parameters will be sampled to determine the inflow of water into the exchange volume, scaled by the ratios of the sampled values of hydraulic gradient and hydraulic conductivity to the relevant values from the SSM.

The uncertainty in retardation ratios and associated partition coefficients for Am, $\mathrm{Ca}, \mathrm{Cm}, \mathrm{Cs}, \mathrm{Eu}, \mathrm{Ho}, \mathrm{Np}, \mathrm{Pu}, \mathrm{Sm}, \mathrm{Sr}$, and $\mathrm{U}$ in the cavity-chimney rubble, for the rock matrix, and for the fracture linings is already represented in the SSM for CHESHIRE. Note that retardation was reduced in the CHESHIRE process model HST to reflect colloidal-facilitated transport. Since the SSM was abstracted from the CHESHIRE process model results for all radionuclides, the SSM incorporates these effects. The values will be used for the SSM until additional information becomes available.

\subsection{Proposed Approach to Applying the PM SSM}

The latest generation of the SSM is very computationally efficient, and defining test-specific parameters such as HSU hydraulic conductivity for the calculation of 
Table 5-9

Far-Field Flow Parameters

\begin{tabular}{|l|c|c|c|c|c|}
\hline \multicolumn{1}{|c|}{ Parameter } & Distribution & $\begin{array}{c}\text { Mean (Log Hydraulic } \\
\text { Conductivity m/d) }\end{array}$ & $\begin{array}{c}\text { Standard } \\
\text { Deviation } \\
\text { (log m/d) }^{a}\end{array}$ & $\begin{array}{c}\text { Lower } \\
\text { Limit }\end{array}$ & $\begin{array}{c}\text { Upper } \\
\text { Limit }\end{array}$ \\
\hline \hline Hydraulic Gradient & Uniform & - & - & 0.005 & 0.02 \\
\hline PVTA & Log-normal & 0.1 & 0.9 & - & - \\
\hline PLFA & Log-normal & 0.1 & 0.9 & - & - \\
\hline UPCU & Log-normal & -0.9 & 0.9 & - & - \\
\hline LPCU & Log-normal & -0.9 & 0.9 & - & - \\
\hline CHVCM & Log-normal & -1.0 & 1.4 & - & - \\
\hline CFCM & Log-normal & -1.4 & 0.9 & - & - \\
\hline CHZCM & Log-normal & -0.2 & 0.5 & - & - \\
\hline KA & Log-normal & 0.1 & 0.9 & - & - \\
\hline BRA & Log-normal & -0.1 & 0.9 & - & - \\
\hline CHVTA & Log-normal & 0.1 & 0.9 & - & - \\
\hline BA & Log-normal & 0.6 & 0.8 & - & - \\
\hline TSA & Log-normal & 0.1 & 0.9 & - & - \\
\hline PBRCM & Log-normal & -0.7 & - & - \\
\hline
\end{tabular}

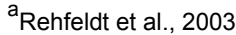

each test's HST is easily done. However, because this is an unclassified analysis the radionuclide distributions cannot be further refined other than as previously described. The SSM process for each realization will involve the following steps:

1. The test inventory will be calculated as the average inventory for a given area (e.g., Area 19 or 20) for a given uncertainty multiplier as given by Bowen et al. (2001).

2. The test inventory will be distributed to the melt glass and exchange volume, based on sampled partition coefficients.

3. Hydraulic gradient and hydraulic conductivity will be sampled from uniform and log-normal distribution, respectively, for the appropriate HSU.

4. Using the test-cavity radius from Pawloski (2004, Appendix A) the exchange volume radius multiplier will be sampled, the components of the exchange volume calculated, and the effective area of the exchange volume calculated from $A_{E V}=\left(V_{E V}\right)^{2 / 3}$.

5. The melt glass yield ratio will be sampled from a uniform distribution and the mass of the melt glass determined from the product of the yield ratio 
and the maximum yield for the test. The volume of the melt glass is determined by the ratio of the melt glass mass and its bulk density, $2,000 \mathrm{~kg} / \mathrm{m}^{3}$. Finally, the effective area of the melt glass is calculated from $A_{M G}=\left(V_{M G}\right)^{2 / 3}$.

6. The retardation ratios for the cavity-chimney rubble, the rock matrix, and the fracture lining (if present) will be sampled for $\mathrm{Am}, \mathrm{Ca}, \mathrm{Cm}, \mathrm{Cs}, \mathrm{Eu}$, $\mathrm{Ho}, \mathrm{Np}, \mathrm{Pu}, \mathrm{Sm}, \mathrm{Sr}$, and $\mathrm{U}$ and applied to the transport of radionuclides in the HST.

It is anticipated that the number of realizations for each HST calculation will be approximately twice the number of sampled distributions. The final number of realizations will be determined through numerical testing of the SSM. 


\subsection{Evaluation of Radionuclide Data}

This section presents the results of the evaluation of radionuclide data conducted to help understand the nature and extent of the radionuclide contamination present in the Pahute Mesa groundwater system. The Pahute Mesa CAIP (DOE/NV, 1999) is the primary reference for the data evaluation. An update is provided based on selected radionuclide data extracted from the GeoChem database (IT, 2002a). Citations from other reference documents are specifically called out in the text. The information was obtained from groundwater sampling conducted on Pahute Mesa and other areas of interest as described in Section 3.0. The available data are discussed by geographical area. Data for Areas 19 and 20 of the NTS are presented first, followed by data available for offsite groundwater sampling sites located within the Pahute Mesa area.

\subsection{NTS Area 19 Data}

A discussion of the radionuclide data available for wells located within NTS Area 19 is provided in this section. Data of interest in Area 19 were collected from sampling sites located near the ALMENDRO (U19v) and CAMEMBERT (U19q) nuclear tests, and UE-19c Water Well (UE-19c WW). Site locations are provided in Figure 6-1.

\subsubsection{ALMENDRO (U19v) Sampling Data}

The ALMENDRO test was conducted June 6, 1973, at a vertical depth of $1,063 \mathrm{~m}$ bgs, approximately $400 \mathrm{~m}$ below the pretest water table (Figure 6-1).

The chimney and cavity regions of the ALMENDRO test are currently accessible via post-test Well U-19v PS-1 D. According to Smith (2002), temperature logs run periodically into the post-test well starting in 1973 through the present indicate anomalously high temperatures persist in the test cavity. In fact, in 1996 a maximum temperature of approximately $157^{\circ} \mathrm{C}$ was recorded at a depth of $1,147 \mathrm{~m}$ bgs within the test cavity (Smith, 2002). No pump has ever been installed in Well U-19v PS-1 D; however, bailed samples have been collected from specific target depths. The results from various sampling dates and depths are shown in Table 6-1. All reported depths are corrected for borehole deviation. It can be seen from the table that the tritium activities are relatively consistent over time with the activities varying from $2.4 \times 10^{8}$ to $1.5 \times 10^{8}$ picocuries per liter $(\mathrm{pCi} / \mathrm{L})$. It can also be seen from the table that the ${ }^{36} \mathrm{Cl}$ and ${ }^{85} \mathrm{Kr}$ activities are relatively consistent, at least within an order of magnitude. 


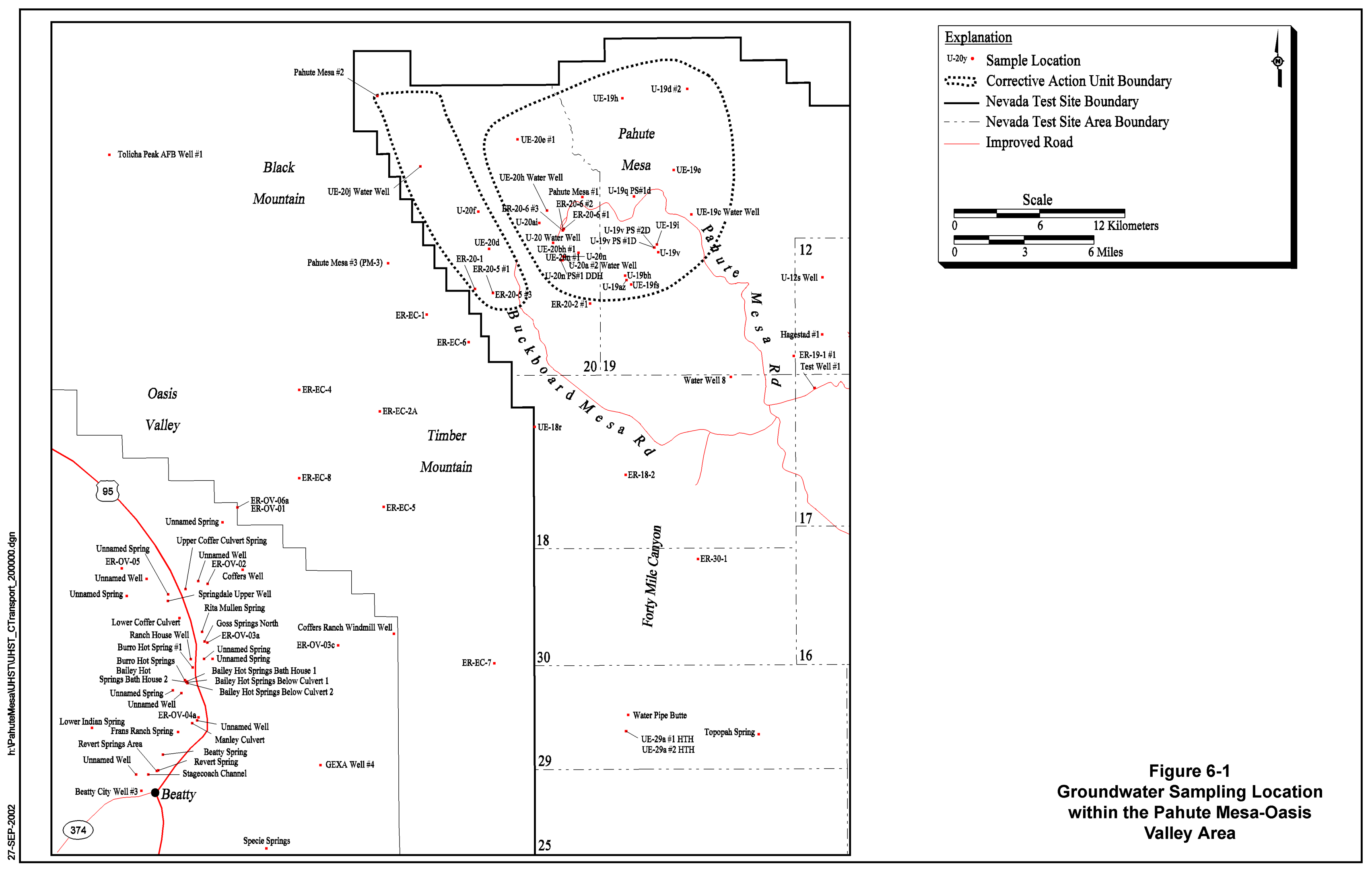


Table 6-1

Radionuclides in Groundwater at ALMENDRO (Well U-19v PS-1 D)

\begin{tabular}{|c|c|c|c|c|c|c|c|c|}
\hline \multirow[b]{2}{*}{ Radionuclide } & \multicolumn{8}{|c|}{ Activity at Time of Collection (pCi/L) with Depth of Sampling Noted } \\
\hline & $\begin{array}{c}09 / 28 / 1993 \\
703 \mathrm{~m} \text { bgs } \\
(2,306 \mathrm{ft} \text { bgs })\end{array}$ & $\begin{array}{c}\mathbf{0 9 / 2 8 / 1 9 9 3} \\
942 \mathrm{~m} \mathrm{bgs} \\
(3,090 \mathrm{ft} \text { bgs })\end{array}$ & $\begin{array}{c}\mathbf{0 7 / 1 9 9 6} \\
942 \mathrm{~m} \text { bgs } \\
(3,090 \mathrm{ft} \text { bgs })\end{array}$ & $\begin{array}{c}\mathbf{0 7 / 1 9 9 6} \\
1,023 \mathrm{~m} \text { bgs } \\
(3,356 \mathrm{ft} \text { bgs })\end{array}$ & $\begin{array}{c}\mathbf{9 / 2 2 / 1 9 9 8} \\
1,021.4 \mathrm{~m} \text { bgs } \\
(3,351 \mathrm{ft} \text { bgs })\end{array}$ & $\begin{array}{c}\mathbf{8} / 18 / 1999 \\
914 \mathrm{~m} \mathrm{bgs} \\
(2,999 \mathrm{ft} \text { bgs })\end{array}$ & $\begin{array}{c}\mathbf{9 / 2 6 / 2 0 0 0} \\
942 \mathrm{~m} \mathrm{bgs} \\
(3,090 \mathrm{ft} \text { bgs })\end{array}$ & $\begin{array}{c}\mathbf{5 / 3 1 / 2 0 0 1} \\
942 \mathrm{~m} \text { bgs } \\
(3,090 \mathrm{ft} \text { bgs })\end{array}$ \\
\hline Tritium & $1.7 \times 10^{8}$ & $2.4 \times 10^{8}$ & $2.0 \times 10^{8}$ & $2.0 \times 10^{8}$ & $1.59 \times 10^{8}$ & $1.6 \times 10^{8}$ & $1.5 \times 10^{8}$ & $1.5 \times 10^{8}$ \\
\hline Chlorine-36 & $N A^{a}$ & NA & NA & NA & NA & $2.14 \times 10^{0}$ & $3.66 \times 10^{0}$ & $3.6 \times 10^{0}$ \\
\hline Cobalt-60 & NA & NA & NA & NA & $<8.57 \times 10^{-2}$ & NA & NA & NA \\
\hline Krypton-85 & $4.0 \times 10^{3}$ & $1.3 \times 10^{5}$ & $9.6 \times 10^{4}$ & $5.4 \times 10^{4}$ & $5.3 \times 10^{4}$ & $5.0 \times 10^{3}$ & $1.9 \times 10^{4}$ & $2.2 \times 10^{3}$ \\
\hline Cesium-137 & NA & NA & \multicolumn{2}{|c|}{$2.7^{\mathrm{b}}$} & $5.68 \times 10^{-1}$ & NA & NA & NA \\
\hline
\end{tabular}

${ }^{\text {aNo analysis }}$

${ }^{\mathrm{b}}$ Sample was a composite of samples from 942 and 1,023 meters (3,090 and 3,356 feet)

Sources: Geochem Database (IT, 2002a), Thompson (1997), Smith et al. (1999), Rose et al. (2002; 2003), Finnegan and Thompson (2002)

Rose et al. (2000a) and Smith (2002) have noted, however, that chemical and isotopic groundwater samples and groundwater level data for ALMENDRO collected within the past several years are not reflective of ambient groundwater conditions in Central Pahute Mesa. For example, Rose et al. (2000a) state that groundwater samples collected in 1998 and 1999 show a significant positive shift in their $\delta$ Oxygen-18 $\left({ }^{18} \mathrm{O}\right)$ isotope ratios $(-13.3$ per mil) relative to other deep Pahute Mesa groundwaters (mean $\delta^{18} \mathrm{O}$ value of -14.9 per mil). They also note that the dissolved inorganic carbon in water taken from the ALMENDRO cavity shows anomalous $\delta^{13} \mathrm{C}$ enriched carbon isotope signatures that may be the result of methanogenic processes involving the reduction of carbon dioxide (Rose et al., 2000a). Smith (2002) also points out that immediately following the ALMENDRO test, the water level dropped approximately $250 \mathrm{~m}$ below the pre-test water level. He further states that periodic monitoring of the water level in the post-test re-entry well suggested that recovery of the water table took approximately twenty years. According to Smith (2002), the anomalous water temperatures, the unusual enrichment in oxygen and carbon isotope ratios, and the slow recovery of the water table to pre-test levels suggests that the water in the ALMENDRO cavity is only partially in contact with the ambient groundwater flow system in central Pahute Mesa.

\subsubsection{CAMEMBERT Test (U19q)}

The CAMEMBERT test (U19q) was conducted on June 25, 1975, at a vertical depth of $1,312 \mathrm{~m}$ bgs.

In 1975, a post-test hole (U-19q PS-1d) was drilled to a depth of 1,521 m. In 1998, it was discovered that the hole had become obstructed with fill to a depth of 
1,125 m. Sampling was conducted in October 1998, after a submersible pump was lowered to a depth of approximately $916 \mathrm{~m}$ (Rose et al., 1999). After purging the well of 12,455 gallons, samples were collected on October 20 and 21, 1998 (Rose et al., 1999). Large amounts of sediment were encountered in the hole during pumping. However, the amount of sediment in the water samples appeared to decrease with time. Only samples collected on the second day of pumping were, therefore, analyzed (Rose et al., 1999). During well purging, tritium concentrations were initially low $\left(\sim 10^{3} \mathrm{pCi} / \mathrm{L}\right)$ but later stabilized at a much higher level. Upon sampling, tritium was detected at $2.1 \times 10^{7} \mathrm{pCi} / \mathrm{L},{ }^{85} \mathrm{Kr}$ at $1.1 \times 10^{5}$ $\mathrm{pCi} / \mathrm{L},{ }^{14} \mathrm{C}$ at $1,310 \mathrm{pCi} / \mathrm{L}$, and ${ }^{36} \mathrm{Cl}$ at $0.1813 \mathrm{pCi} / \mathrm{L}$.

\subsubsection{Water Supply Well UE-19c WW}

Water Supply Well UE-19c WW has been sampled under the annual on-site environmental monitoring program for radioactivity conducted by the

NNSA/NSO and its contractors and under the Long-Term Hydrologic Monitoring Program (LTHMP). The location of this well is shown in Figure 6-1.

Table 6-2 presents the average annual activities for gross alpha, gross beta, and several radionuclides in groundwater from Well UE-19c WW, for the period 1989 to 1996. Well UE-19c WW is a water supply wells on Pahute Mesa that has been periodically sampled each year as part of an on-site environmental monitoring network. The list of analytes and the frequency of sampling have varied over time. Details of changes in the sampling program are beyond the scope of this document and are available in the annual site environmental reports. Sampling at well UE-19c WW ceased in 1992 because the pump in the well became inoperable (REECo, 1994). Also listed in Table 6-2 are the minimum detectable activities (MDAs) for the 1996 data. Comparison of sample data to these MDAs indicates that radionuclide activities in groundwater at wells UE-19c WW were generally below detection during the period of observation. Detected gross alpha and beta activities are due to the presence of naturally occurring radionuclides $\left(\right.$ e.g. ${ }^{40} \mathrm{~K}$, ${ }^{226} \mathrm{Ra}$, and ${ }^{228} \mathrm{Ra}$ ) in groundwater. Variability in the tritium data is due to changes in the analytical method. Prior to 1994, tritium was analyzed by the conventional method and corresponding sample results and detection limits were high (Table 6-2).

Gamma-emitting radionuclides from underground nuclear tests were not detected in LTHMP water samples at this water supply well. Tritium results from the LTHMP are presented in Table 6-3. Only tritium data from the enrichment analyses are shown. This is because the detection limits for the conventional tritium analytical method are too high, and the associated tritium activity data are not meaningful. Table 6-3 shows that tritium activities are below background at this well. 
Table 6-2

Average Annual Groundwater Activity Data for Well UE-19c WW from NTS Environmental Monitoring Program

\begin{tabular}{|c|c|c|c|c|c|c|c|}
\hline Well & Date & $\begin{array}{c}\text { Gross Alpha } \\
(\mathrm{pCi} / \mathrm{L})\end{array}$ & $\begin{array}{c}\text { Gross Beta } \\
(\mathrm{pCi} / \mathrm{L})\end{array}$ & $\begin{array}{c}\text { Plutonium-239/240 } \\
(\mathrm{pCi} / \mathrm{L})\end{array}$ & $\begin{array}{c}\text { Plutonium-238 } \\
(\mathrm{pCi} / \mathrm{L})\end{array}$ & $\begin{array}{c}\text { Strontium-90 } \\
(\mathrm{pCi} / \mathrm{L})\end{array}$ & $\begin{array}{c}\text { Tritium }^{\mathrm{c}} \\
(\mathrm{pCi} / \mathrm{L})\end{array}$ \\
\hline \hline \multirow{3}{*}{ UE-19c WW } & 1989 & $\mathrm{NA}^{\mathrm{b}}$ & 0.88 & $3.8 \times 10^{-3}$ & $\mathrm{ND}$ & $\mathrm{NA}$ & 62 \\
\cline { 2 - 9 } & 1990 & 1.6 & 1.8 & $\mathrm{ND}$ & $\mathrm{ND}$ & $6.3 \times 10^{-2}$ & 230 \\
\cline { 2 - 9 } & 1991 & $\mathrm{NA}$ & 1.5 & $4.3 \times 10^{-2}$ & $2.7 \times 10^{-2}$ & 0.24 & 68 \\
\cline { 2 - 9 } & 1992 & $\mathrm{NA}$ & 2.8 & $6.6 \times 10^{-3}$ & $\mathrm{ND}$ & 0.13 & 44 \\
\hline $\mathrm{MCL}^{\mathrm{d}}$ & - & $1.5 \times 10^{1}$ & $5.0 \times 10^{1}$ & $1.6 \times 10^{0}$ & $1.7 \times 10^{0}$ & $8.0 \times 10^{0}$ & $2.0 \times 10^{4}$ \\
\hline
\end{tabular}

${ }^{a}$ Refer to Figure 6-1 for sampling locations.

bo analysis

'The tritium MDA shown is for enrichment analyses (1994 to 1996); the MDA for conventional analyses is approximately $300 \mathrm{pCi} / \mathrm{L}$.

dMaximum Contaminant Level

Sources: (REECo and EPA, 1990; REECo, 1991, 1992, 1993, 1994, and 1995; BN, 1996 and 1997; CFR, 1998)

Table 6-3

Tritium Activities in Well UE-19c WW from the Long-Term Hydrological Monitoring Program

\begin{tabular}{|c|c|}
\hline Date & $\begin{array}{c}\text { Tritium Activity } \\
\text { (pCi/L) }\end{array}$ \\
\hline \hline 1989 & 2.8 \\
\hline 1990 & $\mathrm{ND}$ \\
\hline 1991 & 0.6 \\
\hline 1992 & $0.5 \pm 2.5$ \\
\hline
\end{tabular}

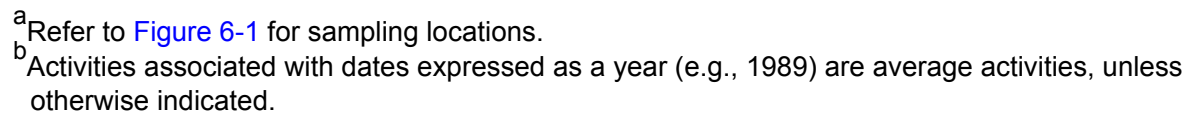

Sources: (REECo and EPA, 1990; REECo, 1991, 1992, and 1993)

\subsection{NTS Area 20 Data}

A discussion of the radionuclide data available for groundwater sites located in NTS Area 20 is provided in this section. Groundwater sampling sites of interest within Area 20 of the NTS are those near the CHESHIRE (U20n) and TYBO (U20y)/BENHAM (U20c) nuclear tests, the ER-20-6 well cluster (near the BULLION [U20bd] nuclear test), U-20 Water Well (U-20 WW), Well Pahute 
Mesa \# 1 (PM-1), and Well Pahute Mesa \# 2 (PM-2). Site locations are provided in Figure 6-1.

\subsubsection{CHESHIRE (U2On)}

The CHESHIRE test took place in February 1976 at a depth of $1,167 \mathrm{~m}$ $(3,828.7 \mathrm{ft})$ in brecciated rhyolitic lava flows, about $540 \mathrm{~m}(1,771 \mathrm{ft})$ below the water table. In late 1976, groundwater from Well U-20n PS\#1 DDH (Figure 6-1) was sampled. The collected groundwater contained a number of fission products, detectable plutonium, and tritium at activities of up to $2 \times 10^{9} \mathrm{pCi} / \mathrm{L}$ (Daniels and Thompson, 1984).

In 1983, the Hydrologic Resources Management Plan (HRMP) recompleted Well U-20n PS\#1 DDH and pumped over $1 \times 10^{4}$ cubic meters $\left(3 \times 10^{6}\right.$ gallons) of water from the hole by May 1985. The well was perforated at a depth of approximately $1,200 \mathrm{~m}$ bgs, close to the CHESHIRE cavity. Hydrologic studies indicated that a natural thermal gradient in the area established a vertical gradient, producing upward groundwater movement (Marsh, 1992). It was speculated that this could allow radionuclides from the cavity to be transported to relatively permeable units above the cavity. To evaluate this possibility, the HRMP plugged and reperforated Well U-20n PS\#1 DDH at a depth of approximately $820 \mathrm{~m}$ bgs, $250 \mathrm{~m}$ above the CHESHIRE cavity and displaced laterally about $100 \mathrm{~m} \mathrm{(328 \textrm {ft } )}$ outside of the chimney.

Table 6-4 lists the activities of radionuclides in groundwater samples collected at Well U-20n PS\#1 DDH. The first four samples were collected at the 1,200-m depth (cavity samples), and the last two samples were collected from a depth of 820-m (formation samples). Comparison indicates that tritium, ${ }^{85} \mathrm{Kr}$, and ${ }^{125} \mathrm{Sb}$ activities are similar at both depths, implying that groundwater (and mobile radionuclides) from the cavity region were migrating upward into overlying permeable units. However, activities of ${ }^{90} \mathrm{Sr}$ and ${ }^{137} \mathrm{Cs}$ in groundwater from the 820-m (2,690-ft) depth are considerably lower than in groundwater from the cavity depth. Well U-20n PS\#1 DDH was also sampled in 1994, 1996, 1997, and 1999. The HRMP reports that the well was not purged prior to sampling in 1994, 1996, and 1997 and that the samples were collected by bailed groundwater from specific target depths.

To further test the hypothesis that groundwater from the cavity region of CHESHIRE was flowing upward into overlying units and then horizontally, Well UE-20n \#1 was installed in 1987 approximately $300 \mathrm{~m}$ downgradient of the test location (Figure 6-1). The total depth of this satellite well is $1,000 \mathrm{~m}$, and it is open to the formation from approximately 700 to $1,000 \mathrm{~m}$ bgs (Thompson, 1988). Temperature and tritium activity, which were monitored during drilling, were greatest in the uppermost relatively permeable zone encountered (roughly 700 to $1,000 \mathrm{~m}$ bgs).

Groundwater samples were collected from various depths at Well UE-20n \#1 during May to August 1987. Table 6-5 presents maximum radionuclide activities observed in these samples. Only maximum values are given in Table 6-5 because 
Table 6-4

Radionuclides in Groundwater at CHESHIRE (Well U-20n PS\#1 DDH)

\begin{tabular}{|c|c|c|c|c|c|c|}
\hline \multirow[b]{2}{*}{ Radionuclide } & \multicolumn{6}{|c|}{ Activity at Time of Collection ( $\mathrm{pCi} / \mathrm{L})$} \\
\hline & $\begin{array}{c}\text { 09/08/1983 } \\
\text { cavity }\end{array}$ & $\begin{array}{c}\text { 08/01/1984 } \\
\text { cavity }\end{array}$ & $\begin{array}{c}\text { 10/23/1984 } \\
\text { cavity }\end{array}$ & $\begin{array}{c}\text { 05/09/1985 } \\
\text { cavity }\end{array}$ & $\begin{array}{l}\text { 06/18/1985 } \\
\text { formation }\end{array}$ & $\begin{array}{c}\text { 11/04/1985 } \\
\text { formation }\end{array}$ \\
\hline Tritium & $3.9 \times 10^{8}$ & $3.3 \times 10^{8}$ & $3.2 \times 10^{8}$ & $3.0 \times 10^{8}$ & $2.4 \times 10^{8}$ & $2.3 \times 10^{8}$ \\
\hline Sodium-22 & 1 & 0.7 & 0.7 & 0.6 & 0.2 & 0.1 \\
\hline Potassium-40 & 5.1 & 5.4 & 4.7 & 5.8 & 13 & 9.8 \\
\hline Cobalt-60 & 0.096 & 0.15 & 0.045 & 0.03 & 0.061 & 0.03 \\
\hline Krypton-85 & $2.0 \times 10^{5}$ & $1.8 \times 10^{5}$ & $1.5 \times 10^{5}$ & $1.6 \times 10^{5}$ & $1.4 \times 10^{5}$ & $1.3 \times 10^{5}$ \\
\hline Strontium-90 & 130 & 98 & 89 & 120 & 4.2 & $N A^{a}$ \\
\hline Rubidium-106 & 5 & 6 & 2 & 0.02 & 5 & 0.7 \\
\hline Antimony-125 & 460 & 390 & 300 & 480 & 270 & 340 \\
\hline Cesium-134 & 0.8 & 0.6 & 0.6 & 0.5 & 0.05 & 0.04 \\
\hline Cesium-137b & 1,200 & 2,000 & 2,300 & 2,100 & 570 & NA \\
\hline Cesium-137 & 920 & 990 & 1,200 & 1,500 & 490 & 550 \\
\hline Europium-152 & $10^{-1}$ & $10^{-1}$ & $10^{-1}$ & $N D^{d}$ & $10^{-1}$ & ND \\
\hline Europium-154 & 0.4 & 0.5 & 0.2 & $10^{-1}$ & 0.2 & $10^{-1}$ \\
\hline Europium-155 & 1 & $10^{-1}$ & $10^{-1}$ & $10^{-1}$ & 1 & $10^{-1}$ \\
\hline Plutonium-239 & 0.2 & 0.1 & 0.2 & NA & 0.1 & NA \\
\hline
\end{tabular}

\footnotetext{
a No analysis

${ }^{\mathrm{b}}$ Radiochemical analysis

${ }^{\mathrm{C}}$ Gamma spectrometry

d Not detected
}

Sources: Thompson, 1986 and 1987

most of the data reported by the HRMP are for samples collected at depths that are outside of the interval with the highest tritium content. The occurrence of radionuclides in groundwater from CHESHIRE at Well UE-20n \#1 provided strong evidence that convectively driven warmer water from deeper zones was flowing upward through the cavity and chimney and then horizontally through permeable units (Marsh, 1991).

Comparison of data from Table 6-4 to Table 6-5 indicates that tritium, ${ }^{85} \mathrm{Kr}$, and ${ }^{125} \mathrm{Sb}$ have migrated from the test cavity with little attenuation. However, comparison of ${ }^{137} \mathrm{Cs}$ activities clearly shows that attenuation has occurred. Based on the amount of tritium observed in groundwater samples from CHESHIRE wells, it was assumed that the leading edge of the radionuclide plume had already passed Well UE-20n \#1 at the time the well was sampled (Marsh, 1992). In February 1988, very high concentrations of fine, colloidal iron oxyhydroxide material (based on visual observation) were found in groundwater at 
Well UE-20n \#1. The origin of the material was not determined, and sampling of the satellite well was stopped. The HRMP determined that a significant fraction of the total radioactivity in groundwater samples from CHESHIRE was associated with colloidal particles.

Table 6-5

Radionuclides in Groundwater at CHESHIRE (Well UE-20n \#1) $)^{a}$

\begin{tabular}{|c|c|}
\hline Radionuclide & Activity at Time of Collection $(\mathbf{p C i} / \mathbf{L})$ \\
\hline \hline Tritium & $3.6 \times 10^{8}$ \\
\hline Sodium-22 & 2.0 \\
\hline Potassium-40 & 160 \\
\hline Krypton-85 & $6.2 \times 10^{4}$ \\
\hline Antimony-125 & 130 \\
\hline Cesium-137 & 2.5 \\
\hline Technetium-99 & 56 \\
\hline
\end{tabular}

${ }^{a}$ Samples collected from May to July 1987

Sources: Thompson, 1988 and Marsh, 1991

Water samples collected from cavity depth (1,200 m bgs) of Well U-20n PS\#1 DDH contained approximately 10 milligrams per liter $(\mathrm{mg} / \mathrm{L})$ of colloidal material, and the colloid mass concentration of groundwater from the formation depth ( $820 \mathrm{~m} \mathrm{bgs}$ ) was approximately $4 \mathrm{mg} / \mathrm{L}$ (Buddemeier, 1988). The colloid mass was defined as the mass of material in the size range of 0.05 to 0.003 micrometers $(\mu \mathrm{m})$. Table 6-6 and Table 6-7 present the sequential filtration results for cavity and formation water from Well U-20n PS\#1 DDH, respectively. Sodium-22, ${ }^{125} \mathrm{Sb},{ }^{134} \mathrm{Cs}$, and ${ }^{137} \mathrm{Cs}$ were present in groundwater predominantly as dissolved species (greater than 50 percent of the total activity in the dissolved fraction as shown in Table 6-6 and Table 6-7). Twenty percent or more of the total activity of manganese- $54,{ }^{60} \mathrm{Co}$, rubidium-106 $\left({ }^{106} \mathrm{Rb}\right),{ }^{144} \mathrm{Ce}$, and europium isotopes was associated with suspended solids (material retained by $1.0 \mu \mathrm{m}$ and $0.45 \mu \mathrm{m}$ filters). Table 6-6 and Table 6-7 indicate that at least 15 percent of the total activity of ${ }^{60} \mathrm{Co},{ }^{106} \mathrm{Rb},{ }^{144} \mathrm{Ce}$, and europium isotopes was also present in the colloidal size range (retained by $0.003 \mu \mathrm{m}$ filter). X-ray diffraction (XRD) studies indicated that the colloids were composed predominantly of quartz and feldspar; clay minerals may also have been present in the colloid fractions (Buddemeier, 1988). Tritium was present as tritiated water.

Pumped groundwater samples collected from the CHESHIRE cavity region in October 1999 contained a maximum tritium activity of $5.1 \times 10^{7} \mathrm{pCi} / \mathrm{L}$ at the time of collection (Rose et al., 2003 Table 5). When this value is decay corrected to time zero (February 14, 1976), this is equivalent to $1.9 \times 10^{8} \mathrm{pCi} / \mathrm{L}$

(Rose et al., 2003, Table 5). Note that this decay corrected value is an order of magnitude lower than the tritium activity measured in the cavity region in late $1976\left(2 \times 10^{9} \mathrm{pCi} / \mathrm{L}\right.$ [Daniels and Thompson, 1984]). This is further direct evidence for the migration of radionuclides out of the CHESHIRE cavity. 
Table 6-6

Filtration Results for Cavity Groundwater at CHESHIRE (Well U-20n PS\#1 DDH) ${ }^{a}$

\begin{tabular}{|c|c|c|c|c|c|c|c|}
\hline \multirow[b]{2}{*}{ Radionuclide } & \multirow{2}{*}{$\begin{array}{c}\text { Total } \\
\text { Activity }^{\mathrm{b}} \\
(\mathrm{pCi} / \mathrm{L})\end{array}$} & \multicolumn{5}{|c|}{ Fraction of Total Activity Retained on } & \multirow{2}{*}{$\begin{array}{c}\text { Fraction } \\
\text { Dissolved }^{d}\end{array}$} \\
\hline & & $\begin{array}{l}1.0 \mu \mathrm{m}^{\mathrm{c}} \\
\text { prefilter }\end{array}$ & $\begin{array}{c}0.45 \mu \mathrm{m} \\
\text { filter }\end{array}$ & $\begin{array}{l}0.20 \mu \mathrm{m} \\
\text { filter }\end{array}$ & $\begin{array}{l}0.05 \mu \mathrm{m} \\
\text { filter }\end{array}$ & $\begin{array}{l}0.003 \mu \mathrm{m} \\
\text { ultrafilter }\end{array}$ & \\
\hline Tritium & $3.1 \times 10^{8}$ & $N A^{e}$ & NA & NA & NA & NA & 1.000 \\
\hline Sodium-22 & 0.82 & $<0.18$ & $<0.01$ & 0.022 & 0.013 & 0.037 & 0.928 \\
\hline Potassium-40 & 4.2 & 0.198 & 0.039 & 0.079 & 0.330 & 0.084 & 0.270 \\
\hline Manganese-54 & 0.029 & 0.750 & 0.250 & $<0.14$ & $<0.12$ & $N D^{f}$ & ND \\
\hline Cobalt-60 & 0.99 & 0.368 & 0.129 & 0.155 & 0.123 & 0.204 & 0.021 \\
\hline Rubidium-106 & 2.5 & 0.321 & 0.129 & 0.158 & 0.070 & 0.178 & 0.144 \\
\hline Antimony-125 & 780 & 0.006 & 0.005 & 0.004 & 0.003 & 0.014 & 0.968 \\
\hline Cesium-134 & 1.5 & 0.111 & 0.038 & 0.048 & 0.067 & 0.057 & 0.679 \\
\hline Cesium-137 & 3,600 & 0.116 & 0.041 & 0.055 & 0.068 & 0.075 & 0.645 \\
\hline Cerium-144 & $4.1 \times 10^{-3}$ & 0.362 & 0.132 & 0.140 & 0.071 & 0.295 & $<0.05$ \\
\hline Europium-152 & 4.3 & 0.359 & 0.127 & 0.162 & 0.135 & 0.209 & 0.008 \\
\hline Europium-154 & 5.6 & 0.364 & 0.130 & 0.161 & 0.127 & 0.218 & $<0.01$ \\
\hline Europium-155 & 9.8 & 0.345 & 0.118 & 0.148 & 0.109 & 0.280 & $<0.03$ \\
\hline
\end{tabular}

\footnotetext{
a Sample collected from approximately $1,200 \mathrm{~m}$ bgs on October 23,1984 ; cavity sample B-4 of Buddemeier (1988)

botal activity at time of collection

cMicrometer

The dissolved fraction is defined as one minus the sum of the fractions retained on the prefilter, filters, and ultrafilter

No analysis

Not detected
}

Source: Buddemeier, 1988

\subsubsection{TYBO (U20y)/BENHAM (U20c)}

TYBO was conducted on May 14, 1975, at a depth of $765 \mathrm{~m} \mathrm{bgs,} 135 \mathrm{~m}$ below the static water table. During 1995 and 1996, the DOE installed Wells ER-20-5 \#1 and \#3 near the site of the TYBO test (Figure 6-1) (DOE/NV, 1997a). Well ER-20-5 \#1 is located approximately $280 \mathrm{~m}$ west of the TYBO test site, and ER-20-5 \#3 is about $30 \mathrm{~m}$ south of ER-20-5 \#1. Well ER-20-5 \#1 was screened at a depth of 701 to $784 \mathrm{~m}$ bgs, the approximate depth of the TYBO cavity. Well ER-20-5 \#3 was screened in a deeper aquifer at 1,046 to $1,183 \mathrm{~m}$ bgs. Groundwater was sampled at these wells on three separate occasions in 1996 and 1997 and analyzed for tritium, gamma emitters, plutonium isotopes, and americium. The results are shown in Table 6-8 and Table 6-9. Radionuclide activities exhibited relatively little change as large volumes of groundwater were pumped from the wells (IT, 1997). 
Table 6-7

Filtration Results for Formation Groundwater at CHESHIRE (Well U-20n PS\#1 DDH) ${ }^{a}$

\begin{tabular}{|c|c|c|c|c|c|c|c|}
\hline \multirow[b]{2}{*}{ Radionuclide } & \multirow{2}{*}{$\begin{array}{c}\text { Total } \\
\text { Activity }^{b} \\
(p C i / L)\end{array}$} & \multicolumn{5}{|c|}{ Fraction of Total Activity Retained on } & \multirow{2}{*}{$\begin{array}{c}\text { Fraction } \\
\text { Dissolved }^{d}\end{array}$} \\
\hline & & $\begin{array}{l}1.0 \mu \mathrm{m}^{\mathrm{c}} \\
\text { prefilter }\end{array}$ & $\begin{array}{l}0.45 \mu \mathrm{m} \\
\text { filter }\end{array}$ & $\begin{array}{c}0.20 \mu \mathrm{m} \\
\text { filter }\end{array}$ & $\begin{array}{c}0.05 \mu \mathrm{m} \\
\text { filter }\end{array}$ & $\begin{array}{l}0.003 \mu \mathrm{m} \\
\text { ultrafilter }\end{array}$ & \\
\hline Tritium & $2.6 \times 10^{8}$ & $N A^{e}$ & NA & NA & NA & NA & 1.000 \\
\hline Sodium-22 & 0.088 & $<0.02$ & $<0.02$ & 0.057 & $<0.28$ & $<0.20$ & 0.943 \\
\hline Potassium-40 & 2.9 & 0.047 & $<0.01$ & $<0.01$ & 0.118 & 0.083 & 0.752 \\
\hline Manganese-54 & 0.004 & \multicolumn{5}{|c|}{ combined filters: 1.0} & $<0.01$ \\
\hline Cobalt- 60 & 0.031 & 0.441 & $<0.05$ & 0.097 & 0.294 & 0.168 & $<0.04$ \\
\hline Rubidium-106 & 4.3 & 0.162 & 0.071 & 0.055 & 0.289 & 0.205 & 0.217 \\
\hline Antimony-125 & 360 & 0.003 & 0.002 & 0.004 & 0.004 & 0.006 & 0.985 \\
\hline Cesium-134 & 0.089 & $N D^{f}$ & ND & ND & ND & 0.024 & 0.976 \\
\hline Cesium-137 & 600 & 0.018 & 0.005 & 0.007 & 0.050 & 0.035 & 0.884 \\
\hline Cerium-144 & $<1.9 \times 10^{-5}$ & ND & ND & ND & ND & ND & ND \\
\hline Europium-152 & 0.10 & 0.237 & $<0.07$ & $<0.08$ & 0.458 & 0.305 & $<0.06$ \\
\hline Europium-154 & 0.14 & 0.245 & $<0.02$ & $<0.02$ & 0.466 & 0.289 & $<0.07$ \\
\hline Europium-155 & 0.23 & 0.173 & 0.034 & 0.066 & 0.382 & 0.345 & $<0.13$ \\
\hline
\end{tabular}

\footnotetext{
a Sample collected from approximately 820 meters (2,690 feet) below ground surface on May 28, 1985. Formation sample B-5 of Buddemeier (1988).

Total activity at time of collection

CMicrometer

d The dissolved fraction is defined as one minus the sum of the fractions retained on the prefilter, filters, and ultrafilter.

${ }^{\mathrm{e}}$ No analysis

Not detected
}

Source: Buddemeier, 1988

Because europium is relatively insoluble, the presence of europium isotopes in unfiltered samples from Well ER-20-5 \#1 was an indication that other low-solubility radionuclides might be present in groundwater (Kersting et al., 1999). To evaluate this possibility, a sample of groundwater from Well ER-20-5 \#1 was subjected to sequential filtration. The results of the filtration experiment are presented in Table 6-10. The data indicate that a large fraction of the total activity of the cationic radionuclides that commonly exhibit strong sorption behavior are associated with colloidal material (defined here as particle sizes between 1 and $0.006 \mu \mathrm{m}$ ). Only a minor fraction of the ${ }^{137} \mathrm{Cs}$ and ${ }^{60} \mathrm{Co}$ activity were present in the dissolved mass. Plutonium was distributed similar to the gamma emitters and less than 1 percent was in the dissolved filtrate (Table 6-10). Using XRD and scanning electron microscopy (SEM), it was determined that the colloidal material was composed of clay, zeolites, cristobalite and minor glass (Thompson, 1998; Kersting et al., 1998). This mineralogy is consistent with the host-rock lithology. 
Table 6-8

Radionuclides in Unfiltered Groundwater at Well ER-20-5 \#1

\begin{tabular}{|c|c|c|c|}
\hline \multirow{2}{*}{ Radionuclide } & \multicolumn{2}{|c|}{ Activity at Time of Collection (pCi/L) } \\
\cline { 2 - 4 } & $\begin{array}{c}\mathbf{0 1 / 0 3 / 1 9 9 6} \\
\left(1.9 \times 10^{1} \mathrm{~m}^{3} \text { pumped }\right)^{\mathrm{a}, \mathrm{b}}\end{array}$ & $\begin{array}{c}\mathbf{0 6 / 0 3 / 1 9 9 6} \\
\left(1.5 \times 10^{3} \mathrm{~m}^{3} \text { pumped }\right)\end{array}$ & $\begin{array}{c}\mathbf{0 4 / 2 2 / 1 9 9 7} \\
\left(1.8 \times 10^{3} \mathrm{~m}^{3} \mathrm{pumped}\right)\end{array}$ \\
\hline \hline Tritium & $6.6 \times 10^{7}$ & $6.8 \times 10^{7}$ & $6.9 \times 10^{7}$ \\
\hline Cobalt-60 & 1.9 & 1.8 & 1.7 \\
\hline Cesium-137 & 11.9 & 15.5 & 15.7 \\
\hline Europium-152 & 1.6 & 1.5 & 1.4 \\
\hline Europium-154 & 1.9 & 1.7 & 1.6 \\
\hline Europium-155 & 0.47 & 0.44 & 0.31 \\
\hline Plutonium-239/240 & 0.53 & 0.26 & 0.63 \\
\hline
\end{tabular}

andicates total volume of water pumped from well at time of sample collection

${ }^{b}$ Cubic meter

Sources: Thompson, 1998; Kersting et al., 1998

Table 6-9

Radionuclides in Unfiltered Groundwater at Well ER-20-5 \#3

\begin{tabular}{|c|c|c|c||}
\hline \multirow{2}{*}{ Radionuclide } & \multicolumn{2}{|c|}{ Activity at Time of Collection (pCi/L) } \\
\cline { 2 - 4 } & $\begin{array}{c}\mathbf{0 2 / 1 5 / 1 9 9 6} \\
\left(3.0 \times 10^{1} \mathrm{~m}^{3} \text { pumped }\right)^{\mathrm{a}, \mathrm{b}}\end{array}$ & $\begin{array}{c}\mathbf{0 7 / 3 1 / 1 9 9 6} \\
\left(2.0 \times 10^{3} \mathrm{~m}^{3} \mathrm{pumped}\right)\end{array}$ & $\begin{array}{c}\mathbf{0 4 / 2 2 / 1 9 9 7} \\
\left(2.2 \times 10^{3} \mathrm{~m}^{3} \mathrm{pumped}\right)\end{array}$ \\
\hline \hline Tritium & $6.5 \times 10^{4}$ & $1.5 \times 10^{5}$ & $1.4 \times 10^{5}$ \\
\hline Cobalt-60 & 0.05 & 0.09 & 0.06 \\
\hline Cesium-137 & 0.17 & 0.14 & 0.06 \\
\hline Europium-152 & $\mathrm{ND}$ & $\mathrm{ND}$ \\
\hline Europium-154 & $\mathrm{ND}$ & $\mathrm{ND}$ & $\mathrm{ND}$ \\
\hline Europium-155 & $\mathrm{ND}$ & $\mathrm{ND}$ & $\mathrm{ND}$ \\
\hline Plutonium-239/240 & $\mathrm{NA}$ & 0.008 & $0.011^{\mathrm{e}} / 0.0085^{\mathrm{f}}$ \\
\hline
\end{tabular}

\footnotetext{
a Indicates total volume of water pumped from well at time of sample collection

${ }^{b}$ Cubic meter

${ }^{\mathrm{c}}$ Not detected

No analysis

Eeported by Thompson (1998)

Reported by Kersting et al. (1998)

Sources: Thompson, 1998; Kersting et al., 1998
} 
Table 6-10

Filtration Results for Groundwater from Well ER-20-5 \#1 ${ }^{\mathrm{a}}$

\begin{tabular}{|c|c|c|c|c|}
\hline \multirow{2}{*}{ Radionuclide } & \multicolumn{2}{|c|}{ Fraction of Total Activity Retained } & \multirow{2}{*}{$\begin{array}{c}\text { Fraction } \\
\text { Dissolved }\end{array}$} \\
\cline { 2 - 5 } & $\begin{array}{c}1.0 \mu \mathrm{m} \\
\text { prefilter }\end{array}$ & $\begin{array}{c}0.05 \mu \mathrm{m} \\
\text { filter }\end{array}$ & $\begin{array}{c}0.006 \mu \mathrm{m} \\
\text { ultrafilter }\end{array}$ & 0.09 \\
\hline \hline Cobalt-60 & 0.16 & 0.39 & 0.37 & 0.05 \\
\hline Cesium-137 & 0.16 & 0.41 & 0.38 & $\mathrm{~b}$ \\
\hline Europium-152 & 0.17 & 0.43 & 0.40 & $\mathrm{~b}$ \\
\hline Europium-154 & 0.17 & 0.43 & 0.40 & $\mathrm{~b}$ \\
\hline Europium-155 & 0.21 & 0.44 & 0.36 & 0.41 \\
\hline
\end{tabular}

\footnotetext{
${ }^{a}$ Sample collected on April 22, 1997; activity fractions based on activity at time of sample collection.

${ }^{b}$ This cell is intentionally blank, no information reported in Thompson (1998). However, it can be assumed that the dissolved fraction is negligible because the other fractions sum to 1.
}

Source: Thompson, 1998

It was initially assumed that the radioactivity in groundwater at Wells ER-20-5 \#1 and \#3 was derived from the TYBO test. To determine the source, the ${ }^{239 / 240} \mathrm{Pu}$ isotopic ratios of the following media were determined:

- Wells ER-20-5 \#1 and \#3 unfiltered groundwater

- Colloidal fraction from Well \#1 groundwater

- Archived melt glass material from the cavity regions of BENHAM and TYBO

- Surface soil from the vicinity of the ER-20-5 well cluster

Evaluation of the ${ }^{239} \mathrm{Pu} /{ }^{240} \mathrm{Pu}$ data indicated that the source of radionuclides in Wells ER-20-5 \#1 and \#3 groundwater was the BENHAM test, not TYBO. BENHAM (U20c) is located approximately $1,300 \mathrm{~m}(4,265 \mathrm{ft})$ north of the ER-20-5 well cluster (Figure 6-1). These findings imply that plutonium may migrate an appreciable distance from the nuclear test where it originated (Thompson, 1998; Kersting et al., 1999).

As part of the hydrologic testing activities conducted at Wells ER-20-5 \#1 and \#3 in mid-1996, groundwater samples were collected from both wells and analyzed for radiological constituents (IT, 1997). The groundwater radiological data for ER-20-5\#1 and \#3 are listed in Table 6-11. Elevated tritium activities were present in groundwater at both wells. In addition, ${ }^{239} \mathrm{Pu} /{ }^{240} \mathrm{Pu}$ was detected at Well \#1 in activities significantly greater than the MDA, and ${ }^{214} \mathrm{~Pb}$ activities in samples from Well \#3 were substantially greater than its MDA. Other than these isotopes, other radioisotopes in groundwater at the ER-20-5 wells were reported at activities that are less than or only slightly above their respective MDAs (Table 6-11). 
Table 6-11

Radionuclides in Groundwater at ER-20-5 Well Cluster

\begin{tabular}{|c|c|c|c|c|c|c|c|c|}
\hline \multirow{2}{*}{ Radionuclide } & \multicolumn{2}{|c|}{$\begin{array}{c}\text { Well ER-20-5 \#1 } \\
\text { (GCP00425) } \\
06 / 03 / 1996\end{array}$} & \multicolumn{2}{|c|}{$\begin{array}{c}\text { Well ER-20-5 \#1 } \\
\text { (GCP00425 duplicate) } \\
\text { 06/03/1996 }\end{array}$} & \multicolumn{2}{|c|}{$\begin{array}{c}\text { Well ER-20-5 \#3 } \\
\text { (GCP00427) } \\
07 / 31 / 1996\end{array}$} & \multicolumn{2}{|c|}{$\begin{array}{c}\text { Well ER-20-5 \#3 } \\
\text { (GCP00427 duplicate) } \\
07 / 31 / 1996\end{array}$} \\
\hline & $\begin{array}{l}\text { Result } \\
(\mathrm{pCi} / \mathrm{L})\end{array}$ & $\begin{array}{c}\text { MDA } \\
(\mathrm{pCi} / \mathrm{L})\end{array}$ & $\begin{array}{l}\text { Result } \\
(\mathrm{pCi} / \mathrm{L})\end{array}$ & $\begin{array}{c}\text { MDA } \\
(\mathrm{pCi} / \mathrm{L})\end{array}$ & $\begin{array}{l}\text { Result } \\
(\mathrm{pCi} / \mathrm{L})\end{array}$ & $\begin{array}{c}\text { MDA } \\
(\mathrm{pCi} / \mathrm{L})\end{array}$ & $\begin{array}{l}\text { Result } \\
(\mathrm{pCi} / \mathrm{L})\end{array}$ & $\begin{array}{c}\text { MDA } \\
(\mathrm{pCi} / \mathrm{L})\end{array}$ \\
\hline Tritium & $\begin{array}{c}7.20 \times 10^{7} \pm \\
7.07 \times 10^{6}\end{array}$ & 5,760 & $\begin{array}{c}7.38 \times 10^{7} \pm \\
7.25 \times 10^{6}\end{array}$ & 5,850 & $\begin{array}{c}1.49 \times 10^{5} \pm \\
1.46 \times 10^{4}\end{array}$ & 194 & $\begin{array}{c}1.52 \times 10^{5} \pm \\
1.49 \times 10^{4}\end{array}$ & 196 \\
\hline Cesium-137 & $11.8 \pm 10.8$ & 10.7 & $22.6 \pm 13.9$ & 16.2 & $N D^{b}$ & 6.79 & ND & 7.66 \\
\hline Lead-214 & $\mathrm{NR}^{\mathrm{a}}$ & NR & $36.6 \pm 20.1$ & 28.3 & $132 \pm 16$ & 14 & $109 \pm 16$ & 13 \\
\hline Plutonium-238 & $0.039 \pm 0.029$ & 0.036 & $0.029 \pm 0.022$ & 0.023 & $0.063 \pm 0.039$ & 0.026 & $0.043 \pm 0.030$ & 0.023 \\
\hline Plutonium-239/240 & $0.76 \pm 0.18$ & 0.03 & $0.63 \pm 0.15$ & 0.03 & $0.030 \pm 0.027$ & 0.028 & ND & 0.029 \\
\hline lodine-129 & ND & 1.1 & ND & 1.0 & ND & 1.00 & ND & 0.866 \\
\hline Strontium-85 & $23.1 \pm 13.1$ & 11.7 & NR & NR & NR & NR & NR & NR \\
\hline Strontium-90 & ND & 0.55 & NR & NR & $4.26 \pm 0.50$ & 0.35 & $0.44 \pm 0.13$ & 0.20 \\
\hline Technetium-99 & ND & 2.26 & $2.62 \pm 1.43$ & 2.32 & ND & 4.66 & ND & 4.69 \\
\hline
\end{tabular}

${ }^{a}$ Not reported

${ }^{\mathrm{b}}$ Not detected

Source: IT, 1997

In April 1998, samples collected from ER 20-5\#3 were found to contain tritium at activities of 1.42 and $1.56 \times 10^{5} \mathrm{pCi} / \mathrm{L}$ for two samples analyzed at the contract laboratory and LLNL. Gross alpha and beta activity was 37.4 and $24.8 \mathrm{pCi} / \mathrm{L}$, respectively. The activity of ${ }^{36} \mathrm{Cl}$ was found to be $1.1 \times 10^{-2} \mathrm{pCi} / \mathrm{L}$. Finally, the activities of the uranium isotopes were as follows: ${ }^{234} \mathrm{U}$ was $2.635 \mathrm{pCi} / \mathrm{L},{ }^{235} \mathrm{U}$ was $4.2 \times 10^{-2} \mathrm{pCi} / \mathrm{L}$ and ${ }^{238} \mathrm{U}$ was $9.02 \times 10^{-1} \mathrm{pCi} / \mathrm{L}$.

During July 1998, a sample collected from ER-20-5\#1 was found to contain tritium with an activity of $6.2 \times 10^{7} \mathrm{pCi} / \mathrm{L}$. Gross alpha and beta activities were reported to be 22.7 and $27.1 \mathrm{pCi} / \mathrm{L}$, respectively. The activities of the three uranium isotopes were as follows: ${ }^{234} \mathrm{U}$ was $15.23 \mathrm{pCi} / \mathrm{L},{ }^{235} \mathrm{U}$ was $0.234 \mathrm{pCi} / \mathrm{L}$ and ${ }^{238} \mathrm{U}$ was $5.01 \mathrm{pCi} / \mathrm{L}$. In addition, ${ }^{238+239} \mathrm{Pu}$ was detected at $0.57 \mathrm{pCi} / \mathrm{L}$. Other nuclides detected in this well include ${ }^{36} \mathrm{Cl}$ at $3.324 \mathrm{pCi} / \mathrm{L},{ }^{137} \mathrm{Cs}$ at $16.3 \mathrm{pCi} / \mathrm{L}$, and ${ }^{85} \mathrm{Kr}$ at $502 \mathrm{pCi} / \mathrm{L}$.

The most recent sampling at the ER 20-5 cluster occurred during fiscal year 2001 (Finnegan and Thompson, 2003; Rose et al., 2003). In November 2001, samples collected from ER 20-5\#3 were found to contain tritium at activities of $5.75 \times 10^{5}$ $\mathrm{pCi} / \mathrm{L}$ and $1.4 \times 10^{5} \mathrm{pCi} / \mathrm{L}$ for samples analyzed at LANL and LLNL respectively. The activity of ${ }^{36} \mathrm{Cl}$ was found to be $2.18 \times 10^{-2} \mathrm{pCi} / \mathrm{L}$, and ${ }^{14} \mathrm{C}$ was $2.08 \mathrm{pCi} / \mathrm{L}$. ${ }^{85} \mathrm{Kr}$ averaged $61.8 \mathrm{pCi} / \mathrm{L}$. Finally, the activities of the uranium isotopes were as follows: ${ }^{234} \mathrm{U}$ was $5.01 \mathrm{pCi} / \mathrm{L},{ }^{235} \mathrm{U}$ was $0.2 \mathrm{pCi} / \mathrm{L}$, and ${ }^{238} \mathrm{U}$ was $4.27 \mathrm{pCi} / \mathrm{L}$. 
Two tasks designed to test the possibility of colloid-facilitated transport between the BENHAM test and the ER-20-5 well cluster have been conducted as part of the Pahute Mesa CAI. They include a colloid study (Kersting and Reimus, 2003) and groundwater flow and transport modeling of the TYBO/BENHAM area (Wolfsberg et al., 2002). The findings of the colloid study are that colloid-facilitated transport of radionuclides is possible within the geochemical conditions found within the Pahute Mesa groundwater system (Kersting and Reimus, 2003). The model results support the feasibility of groundwater flow and transport of radionuclides from BENHAM to the ER-20-5 well cluster in less than 30 years, although other mechanisms such as prompt injection may not completely be ruled out at this time (Wolfsberg et al., 2002).

\subsubsection{ER-20-6 Well Cluster}

The ER-20-6 well cluster is located on Pahute Mesa near the site of the BULLION nuclear test (U20bd) (Figure 6-1). The ER-20-6 well cluster includes three wells: ER-20-6 \#1, ER-20-6 \#2, and ER-20-6 \#3. The three wells were installed during March and April 1996 along a line southwest of BULLION in the approximate direction of natural groundwater flow (Figure 6-1). These wells are located $166 \mathrm{~m}, 207 \mathrm{~m}$, and $296 \mathrm{~m}$, respectively, from BULLION ground zero (DOE/NV, 1998). Radionuclides, apparently associated with BULLION, were detected in groundwater samples from Wells ER-20-6 \#1 and ER-20-6 \#2 (Table 6-12 and Table 6-13). Comparison of data from the first sampling event (early 1996) to data from the second event (late 1996) indicates that activities decreased significantly as groundwater was pumped from the wells.

Well ER-20-6 \#3 was sampled in December 1996, and no tritium or nuclear test-related gamma radioactivity were detected. Tritium detection limits were approximately $1,000 \mathrm{pCi} / \mathrm{L}$, and based on ${ }^{137} \mathrm{Cs}$, the detection limit for gamma-emitters was $0.01 \mathrm{pCi} / \mathrm{L}$.

Samples collected in late 1996 from ER-20-6 \#1 and ER-20-6 \#2 underwent sequential filtration. Thompson (1998) reported that less than 20 percent of ${ }^{125} \mathrm{Sb}$, about 55 percent of ${ }^{137} \mathrm{Cs}$, and over 70 percent of ${ }^{106} \mathrm{Ru}$ were present in filterable form at Well ER-20-6 \#1. In contrast, a small amount (approximately 20 percent or less) of these radionuclides were filterable in groundwater from

Well ER-20-6 \#2.

Groundwater samples were collected from Wells ER-20-6 \#1, ER-20-6 \#2, and ER-20-6 \#3 in November and December 1996. The samples were analyzed for tritium, gamma emitters, and several other radiological constituents; results are shown in Table 6-14. Elevated tritium was detected in groundwater at Wells ER-20-6 \#1 and ER-20-6 \#2, but not at Well ER-20-6 \#3. Other than tritium, no other radionuclides were definitively detected in groundwater from the ER-20-6 wells.

During May 1998, ER-20-6 \#1 and ER-20-6 \#3 were sampled. No radionuclides were found to be present above the method detection limit in groundwater from 
Table 6-12

Radionuclides in Groundwater from Well ER-20-6 \#1

\begin{tabular}{|c|c|c|}
\hline \multirow{2}{*}{ Radionuclide } & \multicolumn{2}{|c|}{ Activity at Time of Collection (pCi/L) } \\
\cline { 2 - 3 } & $\begin{array}{c}03 / 16 / 1996 \\
\left(26 \mathrm{~m}^{3} \text { pumped }\right)^{\mathrm{a}, \mathrm{b}}\end{array}$ & $\begin{array}{c}12 / 17 / 1996 \\
\left(38 \mathrm{~m}^{3} \mathrm{pumped}\right)\end{array}$ \\
\hline \hline Tritium & $1.70 \times 10^{6}$ & $2.89 \times 10^{4}$ \\
\hline Antimony-125 & 183 & $2.7^{\mathrm{C}}$ \\
\hline Cobalt-60 & 0.36 & $\mathrm{NA}^{\mathrm{d}}$ \\
\hline Cesium-137 & 39.8 & $0.64^{\mathrm{C}}$ \\
\hline Rhodium-102 & 0.67 & $\mathrm{NA}$ \\
\hline Ruthenium-106 & 406 & $2.3^{\mathrm{C}}$ \\
\hline
\end{tabular}

andicates total volume of water pumped from well at time of sample collection

${ }^{b}$ Cubic meter

${ }^{\mathrm{C}}$ From analysis of 0.05-micrometer filtrate sample

dNo analysis

Sources: Thompson, 1997 and 1998

Table 6-13

Radionuclides in Groundwater from Well ER-20-6 \#2

\begin{tabular}{|c|c|c|}
\hline \multirow[b]{2}{*}{ Radionuclide } & \multicolumn{2}{|c|}{ Activity at Time of Collection ( $\mathrm{pCi} / \mathrm{L})$} \\
\hline & $\begin{array}{c}\text { 04/02/1996 } \\
\left(76 \mathrm{~m}^{3} \text { pumped }\right)^{\mathrm{a}, \mathrm{b}}\end{array}$ & $\begin{array}{c}11 / 27 / 1996 \\
\left(140 \mathrm{~m}^{3} \text { pumped }\right)\end{array}$ \\
\hline Tritium & $9.44 \times 10^{5}$ & $1.69 \times 10^{5}$ \\
\hline Antimony-125 & 53.5 & $4.3^{c}$ \\
\hline Cobalt-60 & $10^{-2}$ & $N A^{d}$ \\
\hline Cesium-137 & 13.2 & $0.90^{\mathrm{C}}$ \\
\hline Rhodium-102m & 0.15 & NA \\
\hline Ruthenium-106 & 120 & $3.4^{\mathrm{C}}$ \\
\hline
\end{tabular}

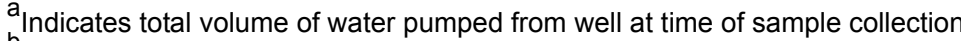

${ }^{b}$ Cubic meter

${ }_{\mathrm{C}}^{\mathrm{c}}$ From analysis of 0.05-micrometer filtrate sample

$\mathrm{d}_{\text {No analysis }}$

Sources: Thompson, 1997 and 1998

both these wells. It should be noted that the MDA for tritium in these samples was $204 \mathrm{pCi} / \mathrm{L}$.

A forced gradient experiment was conducted at the ER-20-6 wells during the summer of 1997. Well ER-20-6 \#3 was continuously pumped from 6/2/97 to 
Table 6-14

Radionuclides in Groundwater at ER-20-6 Well Cluster NNSA/NSO Environmental Restoration Program Sampling

\begin{tabular}{|c|c|c|c|c|c|c||}
\hline \multirow{3}{*}{ Radionuclide } & \multicolumn{2}{|c|}{$\begin{array}{c}\text { Well ER-20-6 } \\
\text { (GCP00436) } \\
12 / 17 / 1996\end{array}$} & \multicolumn{2}{c|}{$\begin{array}{c}\text { Well ER-20-6 \#2 } \\
\text { (GCP00437) } \\
11 / 27 / 1996\end{array}$} & \multicolumn{2}{c|}{$\begin{array}{c}\text { Well ER-20-6 \#3 } \\
\text { (GCP00438) } \\
12 / 16 / 1996\end{array}$} \\
\cline { 2 - 7 } & $\begin{array}{c}\text { Result } \\
(\mathrm{pCi} / \mathrm{L})\end{array}$ & $\begin{array}{c}\text { MDA } \\
\text { (pCi/L) }\end{array}$ & $\begin{array}{c}\text { Result } \\
(\mathrm{pCi} / \mathrm{L})\end{array}$ & $\begin{array}{c}\text { MDA } \\
(\mathrm{pCi} / \mathrm{L})\end{array}$ & $\begin{array}{c}\text { Result } \\
(\mathrm{pCi} / \mathrm{L})\end{array}$ & $\begin{array}{c}\text { MDA } \\
(\mathrm{pCi} / \mathrm{L})\end{array}$ \\
\hline \hline Tritium & $23,200 \pm 2,310$ & 185 & $158,000 \pm 15,500$ & 199 & $\mathrm{ND}^{\mathrm{a}}$ & 183 \\
\hline Cesium-137 & $\mathrm{ND}$ & 11.4 & $<13.5$ & 13.5 & $<13.8$ & 13.8 \\
\hline Plutonium-238 & $\mathrm{ND}$ & 0.17 & $0.02 \pm 0.08$ & 0.22 & $0.072 \pm 0.10$ & 0.21 \\
\hline Plutonium-239/240 & $\mathrm{ND}$ & 0.15 & $\mathrm{ND}$ & 0.22 & $\mathrm{ND}$ & 0.21 \\
\hline lodine-129 & $\mathrm{ND}$ & 0.92 & $0.95 \pm 0.55$ & 0.95 & $\mathrm{ND}$ & 1.2 \\
\hline Strontium-89 & $\mathrm{ND}$ & 0.67 & $\mathrm{NR}$ & $\mathrm{NR}$ & $\mathrm{ND}$ & 0.69 \\
\hline Strontium-90 & $2.19 \pm 0.43$ & 0.48 & $0.15 \pm 0.33$ & 0.57 & $4.21 \pm 0.60$ & 0.49 \\
\hline Technetium-99 & $\mathrm{ND}$ & 1.91 & $4.43 \pm 1.40$ & 2.14 & $1.02 \pm 1.22$ & 2.05 \\
\hline
\end{tabular}

a Not detected

$\mathrm{b}_{\text {Not reported }}$

Source: DOE/NV, 1999

8/28/97. Tracers were injected into wells ER-20-6 \#1 and \#2, and the breakthrough curves of these tracers were characterized with time-series sampling (IT, 1998). During this experiment, significant decreases in soluble radionuclide concentrations were observed in the \#1 and \#2 wells, and modest increases were seen at well \#3. The fact that intensive pumping failed to mobilize radionuclides from the BULLION test cavity suggests the interval from which water was produced is hydrologically isolated from the test cavity (LLNL, 1998).

\subsubsection{Water Supply Well U-20 WW}

Water Supply Well U-20 WW has been sampled under the annual on-site environmental monitoring program for radioactivity conducted by the NNSA/NSO and its contractors and under the LTHMP. The location of this well is shown in Figure 6-1.

Table 6-15 presents the average annual activities for gross alpha, gross beta, and several radionuclides in groundwater from Well U-20 WW, for the period 1989 to 1996. Well U-20 is a water supply well on Pahute Mesa that has been periodically sampled each year as part of an on-site environmental monitoring network. The 
list of analytes and the frequency of sampling have varied over time. Details of changes in the sampling program are beyond the scope of this document and are available in the annual site environmental reports. Also listed in Table 6-15 are the MDAs for the 1996 data. Comparison of sample data to these MDAs indicates that radionuclide activities in groundwater at U-20 WW were generally below detection during the period of observation. Detected gross alpha and beta activities are due to the presence of naturally occurring radionuclides $\left(\right.$ e.g., ${ }^{40} \mathrm{~K}$, ${ }^{226} \mathrm{Ra}$, and ${ }^{228} \mathrm{Ra}$ ) in groundwater. Variability in the tritium data is due to changes in the analytical method. Prior to 1994, tritium was analyzed by the conventional method and corresponding sample results and detection limits were high (Table 6-15).

Table 6-15

Average Annual Groundwater Activity Data for Well U-20 WW from NTS Environmental Monitoring Program

\begin{tabular}{|c|c|c|c|c|c|c|c|}
\hline Well $^{a}$ & Date & $\begin{array}{l}\text { Gross Alpha } \\
\quad(p \mathrm{Ci} / \mathrm{L})\end{array}$ & $\begin{array}{l}\text { Gross Beta } \\
\qquad(p C i / L)\end{array}$ & $\begin{array}{l}\text { Plutonium-239/240 } \\
(\mathrm{pCi} / \mathrm{L})\end{array}$ & $\begin{array}{c}\text { Plutonium-238 } \\
(\mathrm{pCi} / \mathrm{L})\end{array}$ & $\begin{array}{l}\text { Strontium-90 } \\
\quad(p \mathrm{Ci} / \mathrm{L})\end{array}$ & $\begin{array}{c}\text { Tritium }^{\mathbf{b}} \\
(\mathrm{pCi} / \mathrm{L})\end{array}$ \\
\hline \multirow{8}{*}{ U-20 WW } & 1989 & $N A^{c}$ & 2.2 & $N D^{d}$ & ND & NA & 59 \\
\hline & 1990 & 7.2 & 13 & ND & $2.2 \times 10^{-2}$ & $9.3 \times 10^{-2}$ & 72 \\
\hline & 1991 & 7.1 & 7.5 & ND & $1.7 \times 10^{-2}$ & NA & 39 \\
\hline & 1992 & 7.2 & 5.6 & $6.1 \times 10^{-4}$ & ND & 0.30 & ND \\
\hline & 1993 & NA & 2.7 & $4.7 \times 10^{-3}$ & $4.7 \times 10^{-3}$ & 0.52 & 120 \\
\hline & 1994 & 11 & 7.2 & ND & $4.7 \times 10^{-3}$ & NA & ND \\
\hline & 1995 & 5.9 & 3.0 & ND & $2.5 \times 10^{-3}$ & ND & 1.3 \\
\hline & 1996 & 8.4 & 2.7 & ND & $8.4 \times 10^{-3}$ & ND & ND \\
\hline $\mathrm{MCL}^{\mathrm{e}}$ & - & $1.5 \times 10^{1}$ & $5.0 \times 10^{1}$ & $1.6 \times 10^{0}$ & $1.7 \times 10^{0}$ & $8.0 \times 10^{0}$ & $2.0 \times 10^{4}$ \\
\hline
\end{tabular}

${ }^{\mathrm{a}}$ Refer to Figure 6-1 for sampling locations

${ }^{b}$ The tritium MDA shown is for enrichment analyses (1994 to 1996); the MDA for conventional analyses is approximately $300 \mathrm{pCi} / \mathrm{L}$

${ }^{\mathrm{c}}$ No analysis

${ }^{d}$ Not detected

e Maximum Contaminant Level

Sources: (REECo and EPA, 1990; REECo, 1991, 1992, 1993, 1994, and 1995; BN, 1996 and 1997; CFR, 1998)

Gamma-emitting radionuclides from underground nuclear tests were not detected in LTHMP water samples at the two water supply wells. Tritium results from the LTHMP are presented in Table 6-16. Only tritium data from the enrichment analyses are shown. This is because the detection limits for the conventional tritium analytical method are too high, and the associated tritium activity data are not meaningful. Table 6-16 shows that tritium activities are below background at these two wells. 
Table 6-16

Tritium Activities in Well U-20 WW from the Long-Term Hydrological Monitoring Program

\begin{tabular}{|c|c|}
\hline Date & $\begin{array}{c}\text { Tritium Activity } \\
(\mathrm{pCi} / \mathrm{L})\end{array}$ \\
\hline \hline 1989 & $\mathrm{ND}^{\mathbf{c}}$ \\
\hline 1990 & $\mathrm{ND}$ \\
\hline 1991 & 1.0 \\
\hline 1992 & $1.0 \pm 2.7$ \\
\hline 1993 & $0.6 \pm 2.2$ \\
\hline
\end{tabular}

${ }^{a}$ Refer to Figure 6-1 for sampling locations.

${ }^{b}$ Activity associated with dates expressed as a year (e.g., 1989) are average activities, unless otherwise indicated.

${ }^{\mathrm{c}}$ Not detected.

Sources: (REECo and EPA, 1990; REECo, 1991, 1992, 1993, and 1994)

\subsubsection{Well PM-1}

Gamma-emitting radionuclides from underground nuclear tests were not detected in LTHMP water samples for Well PM-1. Tritium results from the LTHMP are presented in Table 6-17. Only tritium data from the enrichment analyses are shown. This is because the detection limits for the conventional tritium analytical method are too high, and the associated tritium activity data are not meaningful. Table 6-17 shows that above-background tritium activities are observed at Well PM-1.

Table 6-17

Tritium Activities in Well PM-1 Water

\begin{tabular}{|c|c|}
\hline \multicolumn{2}{|c|}{$\begin{array}{c}\text { Well PM-1 } \\
\text { (NTS Area 20) }\end{array}$} \\
\hline Date & Tritium Activity (pCi/L) \\
\hline 1992 & $210 \pm 0.2$ \\
1993 & $218 \pm 4.2$ \\
1994 & $200 \pm 2.6^{\mathrm{a}}$ \\
1995 & $220 \pm 3.1^{\mathrm{a}}$ \\
1996 & $210 \pm 3.1^{\mathrm{a}}$ \\
\hline
\end{tabular}

activity is from an individual sample, not an average.

Sources: (REECo, 1993, 1994, and 1995; BN, 1996; BN, 1997)

\subsubsection{Well PM-2}

Well PM-2 is located in the extreme northwest corner of the NTS (Figure 6-1). Well PM-2 was completed to a vertical depth of 2,677 $\mathrm{m}$ in October 1964. In 
1993, elevated tritium levels were detected in groundwater at Well PM-2. The HRMP collected water samples from PM-2 in 1993 and 1994 in an effort to determine the mechanism by which tritium (assumed to come from the SCHOONER test) migrated got into the well. The well was not purged prior to sampling; Thompson (1995) reports that grab samples were collected. Table 6-18 presents the radiological results of HRMP groundwater sampling at Well PM-2.

Table 6-18

Radionuclides in Groundwater at Well PM-2

\begin{tabular}{|c|c|c|c|c|c|c||}
\hline \multirow{2}{*}{ Radionuclide } & \multicolumn{5}{|c|}{ Activity at Time of Collection (pCi/L) with Depth of Sampling Noted } \\
\cline { 2 - 7 } & $\begin{array}{c}\mathbf{1 1 / 3 0 / 1 9 9 3} \\
305 \mathrm{~m} \text { bgs }\end{array}$ & $\begin{array}{c}11 / 30 / 1993 \\
610 \mathrm{~m} \text { bgs }\end{array}$ & $\begin{array}{c}\mathbf{1 1 / 3 0 / 1 9 9 3} \\
823 \mathrm{~m} \text { bgs }\end{array}$ & $\begin{array}{c}\mathbf{0 5 / 0 4 / 1 9 9 4} \\
305 \mathrm{~m} \text { bgs }\end{array}$ & $\begin{array}{c}\mathbf{0 5} / 04 / 1994 \\
823 \mathrm{~m} \text { bgs }\end{array}$ & $\begin{array}{c}\mathbf{0 5} / 04 / 1994 \\
914 \mathrm{~m} \text { bgs }\end{array}$ \\
\hline \hline Tritium & $1.5 \times 10^{4}$ & $7.3 \times 10^{5}$ & $7.0 \times 10^{5}$ & $2.1 \times 10^{4}$ & $7.0 \times 10^{5}$ & $6.9 \times 10^{5}$ \\
\hline Krypton-85 & 14 & ND & ND & 2.4 & ND & 2.4 \\
\hline Cesium-137 & NA & NA & NA & ND & 0.3 & 2.6 \\
\hline Plutonium-238/239 & NA & NA & NA & ND & $0.044 \pm 0.011$ & $0.117 \pm 0.019$ \\
\hline
\end{tabular}

${ }^{a}$ No analysis

${ }^{\mathrm{b}}$ Not detected

Sources: Thompson, 1995; Russell and Locke, 1997

SCHOONER was a near-surface test conducted in 1968 that created a large crater and ejected earth material to distances exceeding $1 \mathrm{~km}$ in an area surrounding the test. Well PM-2, which is $270 \mathrm{~m}$ northwest of the SCHOONER test, was buried under approximately $3 \mathrm{~m}$ of ejecta from the test (Russell and Locke, 1997).

The mechanism for contamination of groundwater at Well PM-2 has not been determined. However, the sudden 4.77-m (15.6-ft) increase in the water level (Russell and Locke, 1997) and the presence of black sludge-like material in the wellbore (Thompson, 1995) may be related to the radiological contamination. Russell and Locke (1997) also report that measured plutonium isotopic ratios suggest SCHOONER as a possible source and this supports the view that contamination was transported into Well PM-2 from the ground surface. Existing information suggests that the radiological contamination may be confined to the wellbore of PM-2. However, no subsequent sampling has been performed.

\subsection{Offsite Radionuclide Data}

A discussion of the radionuclide data available for groundwater sites located off the NTS but within the PM-OV area is provided in this section. Offsite areas of interest include the Oasis Valley discharge area, and the area located between the NTS and the Oasis Valley discharge area. Groundwater sites located in the Oasis Valley discharge area include wells and discharge points at the surface. 
Groundwater sites located between the NTS and the Oasis Valley discharge area are the wells investigated under the Pahute Mesa CAI. Site locations are provided in Figure 6-1.

\subsubsection{Oasis Valley Discharge Area Sampling Data}

Groundwater samples were collected from Oasis Valley sites under the LTHMP and the UGTA Project.

Gamma-emitting radionuclides from underground nuclear tests were not detected in the LTHMP water samples. Tritium results from the LTHMP are presented in Table 6-19. Only tritium data from the enrichment analyses are shown. This is because the detection limits for the conventional tritium analytical method are too high, and the associated tritium activity data are not meaningful. Tritium is generally not detected in groundwater and spring water from off-site locations in the Oasis Valley/Beatty area. Only at Specie Spring is tritium repeatedly detected, and the observed activities appear to be related to tritium fallout in precipitation. The tritium concentration in modern precipitation in the southwestern U.S. is approximately $32 \mathrm{pCi} / \mathrm{L}$, and since the advent of atmospheric thermonuclear weapons testing in 1952, it has been much greater than $32 \mathrm{pCi} / \mathrm{L}$ (e.g., $110 \mathrm{pCi} / \mathrm{L}$ in Albuquerque, New Mexico, measured in 1982) (Phillips et al., 1988).

In response to the findings of the UGTA regional model (DOE/NV, 1997b), USGS personnel collected water samples from springs and shallow wells in the Oasis Valley area on February 10, 1997. The samples were released for tritium analysis by conventional liquid scintillation counting. The results are shown in Table 6-20; tritium MDAs for these samples are 170 or $180 \mathrm{pCi} / \mathrm{L}$. The tritium activities reported for samples from Bailey's Bath House and the Stagecoach Channel exceed the MDA. However, considering the associated analytical error, the results are probably not indicative of the actual tritium activity of the water.

More recently, LLNL measured tritium by the helium accumulation method for a number of environmental wells and springs in the Oasis Valley area, including many of the ER-OV wells, several Oasis Valley springs, and all of the ER-EC wells (Rose et al., 2002). The helium accumulation method has a very low tritium detection limit of about $1.5 \mathrm{pCi} / \mathrm{L}$. In general, observed tritium levels were near or below the detection limit in all of the environmental monitoring locations in the Oasis Valley region.

\subsubsection{Pahute Mesa CAI Wells}

As part of the Pahute Mesa CAI, seven new wells were installed in the area located between the NTS boundary and the Oasis Valley discharge area. The seven wells are: ER-EC-1, ER-EC-2A, ER-EC-4, ER-EC-5, ER-EC-6, ER-EC-7, and ER-EC-8. The locations of these wells are shown in Figure 6-1. These wells were subsequently tested and sampled. The testing program also included 
Table 6-19

Tritium Activities in Oasis Valley Water from the Long-Term Hydrological Monitoring Program

\begin{tabular}{|c|c|c|c|c|c|c|c|c|c|}
\hline \multicolumn{2}{|c|}{$\begin{array}{l}\text { Beatty City Well } \\
\text { (Off Site) }\end{array}$} & \multicolumn{2}{|c|}{$\begin{array}{l}\text { Coffers Well } \\
\text { (Off Site) }\end{array}$} & \multicolumn{2}{|c|}{$\begin{array}{l}\text { Goss Springs } \\
\text { (Off Site) }\end{array}$} & \multicolumn{2}{|c|}{$\begin{array}{l}\text { Specie Springs } \\
\text { (Off Site) }\end{array}$} & \multicolumn{2}{|c|}{$\begin{array}{c}\text { Younghans Ranch House Wel } \\
\text { (Off Site) }\end{array}$} \\
\hline Date $^{b}$ & $\begin{array}{c}\text { Tritium } \\
\text { Activity }^{\mathrm{c}} \\
\text { (pCi/L) }\end{array}$ & Date & $\begin{array}{c}\text { Tritium } \\
\text { Activity } \\
\text { (pCi/L) }\end{array}$ & Date & $\begin{array}{c}\text { Tritium } \\
\text { Activity } \\
\text { (pCi/L) }\end{array}$ & Date & $\begin{array}{c}\text { Tritium } \\
\text { Activity } \\
\text { (pCi/L) }\end{array}$ & Date & $\begin{array}{c}\text { Tritium } \\
\text { Activity } \\
\text { (pCi/L) }\end{array}$ \\
\hline \begin{tabular}{|c}
$04 / 06 / 1989$ \\
$07 / 12 / 1990$ \\
$07 / 02 / 1991$ \\
$07 / 09 / 1992$ \\
$07 / 21 / 1993$ \\
1994 \\
1995 \\
1996
\end{tabular} & $\begin{array}{c}\text { ND } \\
4.2 \pm 2.9 \\
1 \pm 1.8 \\
3.0 \pm 1.5 \\
0.1 \pm 1.6 \\
2.6 \pm 2.2 \\
0.4 \pm 1.8 \\
\text { ND }\end{array}$ & $\begin{array}{c}02 / 01 / 1989 \\
01 / 04 / 1990 \\
07 / 11 / 1990 \\
07 / 11 / 1991 \\
07 / 09 / 1992 \\
07 / 15 / 1993 \\
1994 \\
1995 \\
1996\end{array}$ & $\begin{array}{c}\text { ND } \\
2.2 \pm 2.7 \\
4.8 \pm 2 \\
0.9 \pm 1.8 \\
2.7 \pm 1.5 \\
0.6 \pm 1.4 \\
1.2 \pm 1.2 \\
0.4 \pm 1.9 \\
\text { ND }\end{array}$ & $\begin{array}{c}08 / 14 / 1990 \\
08 / 07 / 1991 \\
08 / 05 / 1992 \\
08 / 20 / 1993 \\
1994 \\
1995\end{array}$ & $\begin{array}{c}\text { ND } \\
0.8 \pm 1.6 \\
0.0 \pm 1.9 \\
0.3 \pm 1.6 \\
3.3 \pm 1.9 \\
0.9 \pm 1.7\end{array}$ & $\begin{array}{c}03 / 08 / 1989 \\
07 / 10 / 1990 \\
07 / 12 / 1991 \\
07 / 09 / 1992 \\
07 / 21 / 1993 \\
12 / 15 / 1993 \\
1994 \\
1995\end{array}$ & $\begin{array}{c}48 \pm 7 \\
20 \pm 2.9 \\
1.8 \pm 1.7 \\
4.6 \pm 1.6 \\
18 \pm 1.6 \\
20 \pm 1.9 \\
26 \pm 2^{\mathrm{e}} \\
24 \pm 4.8\end{array}$ & $\begin{array}{c}01 / 05 / 1989 \\
02 / 01 / 1989 \\
03 / 09 / 1989 \\
06 / 13 / 1990 \\
12 / 05 / 1990 \\
06 / 12 / 1991 \\
06 / 11 / 1992 \\
06 / 24 / 1993 \\
12 / 15 / 1993 \\
1994 \\
1995\end{array}$ & $\begin{array}{c}\text { ND } \\
\text { ND } \\
\text { ND } \\
0.4 \pm 3.2 \\
\text { ND } \\
4.2 \pm 2.6 \\
\text { ND } \\
3.8 \pm 1.6 \\
2.0 \pm 2.8 \\
2.7 \pm 1.2 \\
2.2 \pm 1.2\end{array}$ \\
\hline
\end{tabular}

${ }^{a}$ Also known as Well 12S-47E-7dbd

${ }^{b}$ Activities associated with dates expressed as a year (e.g., 1989) are average activities, unless otherwise indicated

${ }^{c}$ Not detected

Also known as Well 11S-48-1dd

${ }^{\mathrm{e}}$ Activity is from an individual sample, not an average.

Sources: (REECo and EPA, 1990; REECo, 1991, 1992, 1993, 1994, and 1995; BN, 1996; BN, 1997) 
Table 6-20

Tritium Activity of Oasis Valley Water Samples

\begin{tabular}{|c|c|c|}
\hline Sample Location & $\begin{array}{c}\text { Tritium Activity } \\
\text { (pCi/L, unless noted) }\end{array}$ & $\begin{array}{c}\text { Minimum Detectable } \\
\text { Activity } \\
(\mathrm{pCi} / \mathrm{L})\end{array}$ \\
\hline Amargosa Narrows & $\mathrm{ND}^{\mathrm{a}}$ & 170 \\
\hline Amargosa Narrows (duplicate) & 175 & $N R^{b}$ \\
\hline Baileys Bath House 1 & 290 & 180 \\
\hline Baileys Bath House 2 & 180 & 170 \\
\hline Baileys Below Culvert 1 & ND & 180 \\
\hline Baileys Culvert 2 & ND & 170 \\
\hline Baileys Pump House & ND & 170 \\
\hline Frans Ranch & ND & 170 \\
\hline Gexa 4 Well & ND & 170 \\
\hline Lower Coffer Culvert & ND & 170 \\
\hline Lower Indian Spring & ND & 170 \\
\hline Manleys Culvert & ND & 170 \\
\hline Revert Spring 1 & ND & 170 \\
\hline Specie Spring & ND & 170 \\
\hline Stagecoach Channel & 180 & 170 \\
\hline Stagecoach Channel (matrix spike) & 90 (percent recovery) & $N A^{C}$ \\
\hline Upper Coffer Culvert & ND & 170 \\
\hline
\end{tabular}

\footnotetext{
a Not detected

${ }^{b}$ Not reported

${ }^{\mathrm{c}}$ Not applicable

Source: Sobocinski, 1997
}

Well ER-18-2, an existing well. The details of the testing analysis are documented in eight reports (IT, 2002b through i).

Except for Well ER-EC-2A and Well ER-EC-8, radiological indicator parameters were not detected in the groundwater samples of any of the other wells.

\subsubsection{ER-EC-2A}

A radiological indicator parameter was possibly detected in the composite groundwater characterization sample of Well ER-EC-2A. For example, ${ }^{14} \mathrm{C}$ was detected in sample \#EC-2A-072700-1 at an activity of 1,540 +/- $280 \mathrm{pCi} / \mathrm{L}$, which was above the minimum detectable activity. This value, however, is somewhat suspect and tends to conflict with the ${ }^{14} \mathrm{C}$ (percent modern carbon) [pmc]) value that was determined by LLNL for the "Age and Migration Parameters"

(IT, 2002d). 


\subsubsection{ER-EC-8}

A radiological indicator parameter was detected in both of the discrete bailer samples for Well ER-EC-8 at activities that were above the minimum detectable activity (IT, 2002i). For example, it can be seen in the "Radiological Indicator Parameters" (Table 6-21) that ${ }^{239} \mathrm{Pu}$ was present at an activity of $0.101+/-$ $0.036 \mathrm{pCi} / \mathrm{L}$ in discrete bailer sample \#EC-8-062800-2. It can also be seen from the table that ${ }^{239} \mathrm{Pu}$ was detected in discrete bailer sample \#EC-8-062800-3 at an activity of $0.066+/-0.03 \mathrm{pCi} / \mathrm{L}$. This activity is less than the requested minimum detectable activity, but greater than the sample specific minimum detectable activity (IT, 2002i).

Table 6-21

Results of Analysis for ER-EC-8 Water Samples: Radiological Indicator Parameters

\begin{tabular}{|c|c|c|c|c|c|}
\hline Analyte & CRDL & Laboratory & $\begin{array}{c}\text { Results of Discrete } \\
\text { Bailer } \\
\text { Sample \#EC-8-062800-2 }\end{array}$ & $\begin{array}{c}\text { Results of Discrete Bailer } \\
\text { Sample \#EC-8-062800-3 }\end{array}$ & $\begin{array}{c}\text { Results of Wellhead } \\
\text { Composite } \\
\text { Sample \#EC-8-071200-1 }\end{array}$ \\
\hline \hline Potassium-40 & $77,160,160$ & Paragon & $264+/-83$ & ND & ND \\
\hline Tritium & $250,250,270$ & Paragon & ND & ND & ND \\
\hline Gross Alpha & $3.1,3.1,3.8$ & Paragon & $8.1+/-2.7$ & $7.7+/-2.7$ & ND \\
\hline Gross Beta & $3.6,4.1,4.1$ & Paragon & ND & ND & ND \\
\hline Carbon-14 & $310,310,310$ & Paragon & ND & N/A & ND \\
\hline Strontium-90 & 0.44 & Paragon & N/A & ND \\
\hline Plutonium-238 & $\begin{array}{c}0.034,0.026, \\
0.034\end{array}$ & Paragon & ND & LT $0.066+/-0.030$ & ND \\
\hline Plutonium-239 & $0.0081,0.0089$, & Paragon & $0.101+/-0.036$ & N/A & ND \\
\hline lodine-129 & 1.4 & Paragon & N/A & N/A & ND \\
\hline Technetium-99 & 13 & Paragon & N/A & \\
\hline
\end{tabular}

$\mathrm{ND}=$ Not detected

$\mathrm{LT}=$ Result is less than requested MDC, but greater than sample-specific MDC

$\mathrm{N} / \mathrm{A}=$ Not applicable for that sample

$\mathrm{pCi} / \mathrm{L}=$ Picocuries per liter

Source: Modified from IT, 2002

The detection of ${ }^{239} \mathrm{Pu}$ activities in the discrete bailer samples from Well ER-EC-8 was unexpected because this radiological indicator had not previously been found in any of the other PM-OV hydrogeologic investigation wells. To rule out the discrete bailer as a potential source of the ${ }^{239} \mathrm{Pu}$ activities, the analytical results from the equipment rinsate sample (\#EC-8-062800-1) were investigated. Equipment rinsate samples were collected from the final rinse solution from the equipment decontamination process to assess the effectiveness of the decontamination process. The analytical results from the rinsate sample revealed $\mathrm{a}^{239} \mathrm{Pu}$ activity of $0.0013+/-0.0086 \mathrm{pCi} / \mathrm{L}$. This value was qualified as a result that was not detected at the given minimum detectable activity. This implies that the discrete bailer was not the source of the ${ }^{239} \mathrm{Pu}$ activity.

To further validate the original analytical results, two duplicate groundwater samples were sent to LANL for analysis in July 2001. Los Alamos National 
Laboratory reported that a blank sample was run before, between, and after the two duplicate samples to check for any possible contamination of the samples. They stated that all of the results for the blanks were non-detects (LANL, 2001). Table 6-22 displays the results of the ${ }^{238} \mathrm{Pu}$ and ${ }^{239} \mathrm{Pu}$ measurements. Los Alamos National Laboratory (2001) reported that all of the analytical results were considered non-detects as the detected activities are well below the minimum detectable activities and are overwhelmed by the associated error in most cases. They also state that the negative values are consistent with the statistical nature of radioactivity and are indicative of the fact that ${ }^{238} \mathrm{Pu}$ and ${ }^{239} \mathrm{Pu}$ were not present in the discrete bailer samples (LANL, 2001).

Table 6-22

Results of Plutonium Analyses for Well ER-EC-8 Discrete Bailer Samples

\begin{tabular}{||c|c|c|c|c|c|}
\hline Isotope & Sample \# & IT Sample \# & Volume (L) & $\begin{array}{c}\text { pCi/L +/- 2 } \\
\text { sigma }\end{array}$ & MDA \\
\hline \hline Pu-239 & 000374 & EC-8-062800-2 & 0.440 & ND & 0.0058 \\
\hline Pu-239 & 000375 & EC-8-062800-3 & 0.380 & ND & 0.0078 \\
\hline Pu-238 & 000374 & EC-8-062800-2 & 0.440 & ND & 0.0058 \\
\hline Pu-238 & 000375 & EC-8-062800-3 & 0.380 & ND & 0.0048 \\
\hline
\end{tabular}

Source: IT, 2002i

\subsection{Summary}

The available groundwater sampling data show that radionuclides related to underground nuclear testing are present at detectable levels in groundwater at Pahute Mesa. However, except for the ER-20-5 well cluster, radionuclide contamination has only been observed in cavity water and in areas relatively close to the nuclear test locations. At the ER-20-5 well cluster, radionuclides were found in groundwater samples collected at wells \#1 and \#3 located near the TYBO test. The data indicate that a large fraction of the total activity of each radionuclide was associated with colloidal material. Evaluation of the ${ }^{239,240} \mathrm{Pu}$ data indicated that the source of radionuclides in Well ER-20-5 groundwater was the BENHAM test, not the TYBO test. BENHAM (U20c) is located approximately 1,300 m north of the ER-20-5 well cluster. These findings imply that radionuclides may migrate an appreciable distance from the nuclear test where they originated (Thompson, 1998; Kersting et al., 1998). 


\subsection{Summary and Limitations}

The Pahute Mesa CAU transport model requires that the sources of contamination be defined as input to the model. The sources are generally accepted to be the radionuclides released into groundwater from underground nuclear test cavities. A method for estimating the unclassified hydrologic source terms for nuclear tests conducted in Areas 19 and 20 was developed. In this method, a simplified version of an HST process model was developed using Goldsim ${ }^{\circledR}$. This simplified method was tested against the detailed process model calculations for the CHESHIRE test. A procedure is presented for estimating the source term for the underground nuclear tests of Pahute Mesa using estimates of the unclassified radiologic source terms published by Bowen et al. (2001), hydrologic information from the Pahute Mesa hydrologic data document (SNJV, 2004), and test-specific characteristics.

The radionuclide data available for groundwater sampling sites located within the the Pahute Mesa Oasis Valley area were compiled and assessed. These data will be used to attempt to constrain the simulation results of the CAU radionuclide transport model.

The simplified hydrologic source term model presented in this document is based on simplifying assumptions that may place limitations on the results. The assumptions or simplifications and associated limitations are identified in Table 7-1. 
Table 7-1

Source Model Assumptions or Simplifications and Associated Limitations

\begin{tabular}{||l|l||}
\hline \multicolumn{1}{|c|}{ Assumption or Simplification } & \multicolumn{1}{c|}{ Limitation } \\
\hline \hline $\begin{array}{l}\text { Total mass of each radionuclide in the study area is based } \\
\text { on the unclassified inventory of Bowen et al. (2001). Bowen } \\
\text { et al. (2001) also provides estimates of the associated } \\
\text { accuracies. }\end{array}$ & $\begin{array}{l}\text { The total mass of radionuclides in Area 19 or Area 20 as provided by } \\
\text { Bowen et al. (2001) is an adequate estimate and is not considered a } \\
\text { significant limitation. }\end{array}$ \\
\hline $\begin{array}{l}\text { The initial mass of each radionuclide for each underground } \\
\text { test is calculated as the total inventory for the } \\
\text { corresponding NTS area averaged by the number of tests in } \\
\text { that area. }\end{array}$ & $\begin{array}{l}\text { The initial mass of any radionuclide at a particular test may be } \\
\text { significantly in error as a result of this simplification. To overcome } \\
\text { this limitation, classified, test-specific data would be required. } \\
\text { Radionuclide concentrations in the near field cannot be expected to } \\
\text { match observed data in the near field. }\end{array}$ \\
\hline $\begin{array}{l}\text { Radionuclides are assumed to be uniformly distributed in } \\
\text { the exchange volume and melt glass. }\end{array}$ & $\begin{array}{l}\text { The spatial variability of radionuclide mass in the cavity region could } \\
\text { lead to errors when comparing to measured data in cavities, even if } \\
\text { classified source inventories are used. }\end{array}$ \\
\hline $\begin{array}{l}\text { The chemical reactions are based on assumed linear } \\
\text { adsorption isotherms. }\end{array}$ & $\begin{array}{l}\text { The work of Tompson et al. (1999) and Pawloski et al. (2002) clearly } \\
\text { show that near field heterogeneity in reactive mineral distribution } \\
\text { controls the near-field migration of radionuclides. At larger } \\
\text { distances, the linear isotherm approach is expected to have greater } \\
\text { validity, if } \mathrm{K}_{\mathrm{d}} \text { values can be defined. }\end{array}$ \\
\hline $\begin{array}{l}\text { Solubility limits on melt glass dissolution are ignored in this } \\
\text { analysis. }\end{array}$ & $\begin{array}{l}\text { The radionuclide flux due to melt glass dissolution may be } \\
\text { overestimated by ignoring factors such as silica solubility, that might } \\
\text { limit dissolution. }\end{array}$ \\
\hline
\end{tabular}




\subsection{References}

BN, see Bechtel Nevada.

Bechtel Nevada. 1996. Nevada Test Site Annual Site Environmental Report for Calendar Year 1995, DOE/NV/11718-037. Las Vegas, NV.

Bechtel Nevada. 1997. Nevada Test Site Annual Site Environmental Report for Calendar Year 1996, DOE/NV/11718-137. Las Vegas, NV.

Bechtel Nevada. 2002. A Hydrostratigraphic Model and Alternatives for the Groundwater Flow and Contaminant Transport Model of Corrective Action Units 101 and 102: Central and Western Pahute Mesa, Nye County, Nevada, DOE/NV/11718-706. Prepared for U.S. Department of Energy, National Nuclear Security Administration Nevada Operations Office. Las Vegas, NV.

Borg, I.Y., R. Stone, H.B. Levy, and L.D. Ramspott. 1976. Information Pertinent to the Migration of Radionuclides in Ground Water at the Nevada Test Site, Part 1: Review and Analysis of Existing Information, UCRL-52078. Livermore, CA: Lawrence Livermore National Laboratory.

Bowen, S.M., D.L. Finnegan, J.L. Thompson, C.M. Miller, P.L. Baca, L.F. Olivas, C.G. Geoffrion, D.K. Smith, W. Goishi, B.K. Esser, J.W. Meadows, N. Namboodiri, and J.F. Wild. 2001. Nevada Test Site Radionuclide Inventory, 1951-1992, LA-13859-MS. Los Alamos, NM: Los Alamos National Laboratory.

Buddemeier, R.W. 1988. Hydrology and Radionuclide Migration Program 1985-1986 Progress Report, UCRL-53779. Livermore, CA: Lawrence Livermore National Laboratory.

CFR see Code of Federal Regulations.

CRWMS, see Civilian Radioactive Waste Management System Management and Operating Contractor.

Code of Federal Regulations. 1998. Title 40 CFR Part 141.15 and 16, "Maximum Contaminant Levels for Beta Particle and Photon Radioactivity from Man-made Radionuclides in Community Water Systems". Washington, DC: U.S. Government Printing Office. 
Civilian Radioactive Waste Management System Management and Operating Contractor. 2000. Calibration of the Site-Scale Saturated Zone Flow Model, MDL-NBS-HS-000011, Rev. 00. Las Vegas, NV.

Daniels, J.I., R. Andricevic, L.R. Anspaugh, and R.L. Jacobson. 1993. Risk Based Screening Analysis of Ground Water Contaminated by Radionuclides Introduced at the Nevada Test Site (NTS), UCRL-LR-113891. Livermore, CA: Lawrence Livermore National Laboratory.

Daniels, W.R., and J.L. Thompson, comp. and eds. 1984. Laboratory and Field Studies Related to the Hydrology/Radionuclide Migration Project (October 1, 1982 - September 30, 1983), LA-10121-PR. Los Alamos, NM: Los Alamos National Laboratory.

Dash, Z.V. 2000. Validation Test Report (VTR) for the FEHM Application Version 2.10 Yucca Mountain Project Identification Numbers SAN: LANL-1999-046; STN: 10086-2.10-00. Los Alamos, NM: Los Alamos National Laboratory.

Dash, Z.V. 2001. Validation Test Report (VTR) for the FEHM Application Version 2.12, Yucca Mountain Project Identification Numbers SAN: LANL-2001-133; STN: 19986-2,12-00. Los Alamos, NM: Los Alamos National Laboratory.

Dash, Z.V., B.A. Robinson, and G.A. Zyvoloski. 1997. Software Requirements, Design, and Verification and Validation for the FEHM Application - A Finite-Element Heat- and Mass-Transfer Code, LA-13305-MS. Los Alamos, NM: Los Alamos National Laboratory

DOE, see U.S. Department of Energy.

DOE/NV, see U.S. Department of Energy, Nevada Operations Office

FFACO, see Facility Agreement and Consent Order.

Federal Facility Agreement and Consent Order. 1996 (as amended). Agreed to by the State of Nevada, the U.S. Department of Energy, and the U.S. Department of Defense.

Finkel, R.C., M.W. Caffee, K.V. Marsh, and J.H. Rego. 1992. Accelerator Mass Spectrometry Measurements of I129 in CHESHIRE Site Groundwater, UCRL-53779-88: 11-12. Livermore, CA: Lawrence Livermore National Laboratory.

Finnegan, D.L., and J.L. Thompson, 2002. Laboratory and Field Studies Related to Radionuclide Migration at the Nevada Test Site in Support of the Underground Test Area and Hydrologic Resources Management Projects, LA-13919-MS. Los Alamos, NM: Los Alamos National Laboratory. 
Finnegan, D.L., and J.L. Thompson, 2003. Laboratory and Field Sudies Related to Radionuclide Migration at the Nevada Test Site in Support of the Underground Test Area and Hydrologic Resources Management Projects, October 1, 2001-September 30, 2002, LA-14042-PR. Los Alamos, NM: Los Alamos National Laboratory.

George, D.C. 1997. Unstructured 3D Grid Toolbox for Modeling and Simulation, LA-UR-97-3052. Los Alamos, NM: Los Alamos National Laboratory.

Golder Associates. 2002a. User's Guide: GoldSim Contaminant Transport Module, Version 1.30. Redmond, WA: Golder Associates, Inc.

Golder Associates. 2002b. User's Guide: GoldSim Graphical Simulation Environment, Version 7.40. Redmond, WA: Golder Associates, Inc.

IAEA, see International Atomic Energy Agency.

International Atomic Energy Agency. 1998. The Radiological Situation at the Atolls of Mururoa and Fangataufa, Technical Report, Volume 3: Inventory of Radionuclides Underground at the Atolls, IAEA-MFTR-3. Proceedings of an IAEA Conference, Vienna, 30 June - 3 July 1998, to present the results of the International Study. Vienna, Austria.

IT Corporation. 1997. Hydrologic Testing Documentation Package for Wells ER-20-5 \#1 and ER-20-5 \#3. Las Vegas, NV.

IT Corporation. 1998. Report and Analysis of the BULLION Forced-Gradient Experiment, DOE/NV/13052-042, Rev. 0. Las Vegas, NV.

IT Corporation. 2002a. A User's Guide to the Comprehensive Chemistry Database for Groundwater at the Nevada Test Site, ITLV/13052-070, Rev, 4. Las Vegas, NV.

IT Corporation. 2002b. Analysis of Well ER-EC-1 Testing, Western Pahute Mesa-Oasis Valley FY 2000 Testing Program, ITLV/13052-173., Rev. 0. Las Vegas, NV.

IT Corporation. 2002c. Analysis of Well ER-18-2 Testing, Western Pahute Mesa Oasis Valley FY 2000 Testing Program, ITLV/13052-172, Rev. 0. Las Vegas, NV.

IT Corporation. 2002d. Analysis of Well ER-EC-2a Testing, Western Pahute Mesa-Oasis Valley FY 2000 Testing Program, ITLV/13052-174, Rev. 0. Las Vegas, NV.

IT Corporation. 2002e. Analysis of Well ER-EC-4 Testing, Western Pahute Mesa-Oasis Valley FY 2000 Testing Program, ITLV/13052-175, Rev. 0. Las Vegas, NV. 
IT Corporation. 2002f. Analysis of Well ER-EC-5 Testing, Western Pahute Mesa-Oasis Valley FY 2000 Testing Program, ITLV/13052-176, Rev. 0. Las Vegas, NV.

IT Corporation. 2002g. Analysis of Well ER-EC-6 Testing, Western Pahute Mesa-Oasis Valley FY 2000 Testing Program, ITLV/13052-177, Rev. 0. Las Vegas, NV.

IT Corporation. 2002h. Analysis of Well ER-EC-7 Testing, Western Pahute Mesa-Oasis Valley FY 2000 Testing Program, ITLV/13052-178, Rev. 0. Las Vegas, NV.

IT Corporation. 2002i. Analysis of Well ER-EC-8 Testing, Western Pahute Mesa-Oasis Valley FY 2000 Testing Program, ITLV/13052-179, Rev. 0. Las Vegas, NV.

Kersting, A.B., D. W. Efurd, D.L. Finnegan, D.J. Rokop, D.K. Smith, and J.L. Thompson. 1998. "Migration of Plutonium in Groundwater at the Nevada Test Site.” In Hydrologic Resources Management Program and Underground Test Area Operable Unit FY 1997 Progress Report, UCRL-ID-130792. Livermore, CA: Lawrence Livermore National Laboratory.

Kersting, A.B., D.W. Efurd, D.L. Finnegan, D.J. Rokop, D.K. Smith, and J.L. Thompson. 1999. "Migration of Plutonium in Ground Water at the Nevada Test Site." In Nature, Vol. 397 (7): 56-59. New York, NY: McMillan Publishing Company.

Kersting, A.B., and P.W. Reimus. 2003. Colloid-Facilitated Transport of Low-Solubility Radionuclides: A Field, Experimental, and Modeling Investigation, UCRL-ID-149688. Livermore, CA: Lawrence Livermore National Laboratory.

Laczniak, R.J., J.C. Cole, D.A. Sawyer, and D.A. Trudeau. 1996. Summary of Hydrogeologic Controls on Ground-Water Flow at the Nevada Test Site, Nye County, Nevada, USGS-WRIR-96-4109. Denver, CO: U.S. Geological Survey.

LANL, see Los Alamos National Laboratory.

LLNL, see Lawrence Livermore National Laboratory.

Lawrence Livermore National Laboratory. 1998. Isotopic Analyses: ER-20-6 Forced Gradient Experiment, letter report. Livermore, CA: Isotope Hydrology Team, Isotope Sciences Division. 
Los Alamos National Laboratory. 2001. Memo to R. Bangerter (U.S. Department of Energy, Nevada Operations Office) that reports radiochemistry and environmental isotope data for Well ER-EC-8, 28 February. Livermore, CA: Isotope Tracers and Transport Team, Analytical \& Nuclear Chemistry Division.

Marsh, K.V. comp. 1991. Hydrology and Radionuclide Migration Program, 1987 Progress Report, UCRL-53779-87. Livermore, CA: Lawrence Livermore National Laboratory.

Marsh, K.V., comp. 1992. Hydrology and Radionuclide Migration Program, 1988 Progress Report, UCRL-53779-88. Livermore, CA: Lawrence Livermore National Laboratory.

Nimz, G.J., and J.L. Thompson. 1992. Underground Radionuclide Migration at the Nevada Test Site, DOE/NV-346. Las Vegas, NV: Reynolds Electrical \& Engineering Co., Inc.

Nitao, J.J. 1988. Reference Manual for the NUFT Flow and Transport Code, Version 2.0, UCRL-MA-130651. Livermore, CA: Lawrence Livermore National Laboratory.

Nitao, J.J. 1989. User's Manual for the USNT Module of the NUFT Code, Version 2.0.1 (NP-Phase, NC-Component, Thermal), UCRL-MA-130653-Rev. 1. Livermore, CA: Lawrence Livermore National Laboratory.

Pawloski, G.A. 1999. Development of Phenomenological Models of Underground Nuclear Tests on Pahute Mesa, Nevada Test Site-BENHAM and TYBO, UCRL-ID-136003. Livermore, CA: Lawrence Livermore National Laboratory.

Pawloski, G.A., A.F.B. Tompson, and S.F. Carle, eds. 2002. Evaluation of the Hydrologic Source Term from Underground Nuclear Test on Pahute Mesa at the Nevada Test Site: the CHESHIRE Test, UCRL-ID-147023-DR. Livermore, CA: Lawrence Livermore National Laboratory.

Pawloski, G.A., Lawrence Livermore National Laboratory. 2004. Personal communication with B. Deshler (Stoller-Navarro Joint Venture) regarding a draft report entitled Categorization of Underground Nuclear Tests on Pahute Mesa, Nevada Test Site, for use in Radionuclide Transport Models, 28 July. Livermore, CA.

Phillips, F.M., J.L. Mattick, T.A. Duval, D. Elmore, and P.W. Kubik. 1988. "Chlorine 36 and Tritium from Nuclear Weapons Fallout as Tracers for Long-Term Liquid and Vapor Movement in Desert Soils." In Water Resources Research, Vol. 24, (11): 1877-1891. Washington, DC: American Geophysical Union.

REECo, see Reynolds Electrical \& Engineering Co., Inc. 
Rehfeldt, K., W. Drici, D. Sloop, J. Watrus, T. Beard, M. Sully, C. Benedict, A. Wolsbergrand, and P. Reimus. 2003. Contaminant Transport Parameters for the Groundwater Flow and Contaminant Transport Model of Corrective Action Units 101 and 102: Central and Western Pahute Mesa, Nye County, Nevada, Shaw/13052-201, Rev. 0. Las Vegas, NV: Shaw Environmental, Inc.

Reynolds Electrical \& Engineering Co., Inc. 1991. Nevada Test Site Annual Site Environmental Report - 1990, Vols. I and II, DOE/NV/10630-20.

E.M. McDowell, and S.C. Black, eds. Las Vegas, NV.

Reynolds Electrical \& Engineering Co., Inc. 1992. Nevada Test Site Annual Site Environmental Report - 1991, Vols. I and II, DOE/NV/10630-33. S.C. Black, A.R. Latham, and Y.E. Townsend, eds. Las Vegas, NV.

Reynolds Electrical \& Engineering Co., Inc. 1993. Nevada Test Site Annual Site Environmental Report - 1992, Vols. I and II, DOE/NV/10630-66. S.C. Black, A.R. Latham, and Y.E. Townsend, eds. Las Vegas, NV.

Reynolds Electrical \& Engineering Co., Inc. 1994. Nevada Test Site Annual Site Environmental Report - 1993, Vols. I and II, DOE/NV/11432-123. S.C. Black, W.M. Glines, and Y.E. Townsend, eds. Las Vegas, NV.

Reynolds Electrical \& Engineering Co., Inc. 1995. Nevada Test Site Annual Site Environmental Report - 1994, DOE/NV/11432-175. S.C. Black, W.M. Glines, and Y.E. Townsend, eds. Las Vegas, NV.

Reynolds Electrical \& Engineering Co., Inc., and U.S. Environmental Protection Agency. 1990. Nevada Test Site Annual Site Environmental Report - 1989, Vols. I and II, DOE/NV/10630-11, D.T. Wruble, and E.M. McDowell, eds. Las Vegas, NV.

Rose, T.P., Eaton, G.F., Smith, D.K., Kenneally, J.M., and G.B. Hudson, 1999. FY 1998 Re-entry, Re-conditioning, and Sample Analyses at Camembert (U-19q PS-1d). In D.K. Smith and G.F. Eaton (eds.), Hydrologic Resources Management Program and Underground Test Area FY 1998 Progress Report, UCRL-ID-135170. Livermore, CA: Lawrence Livermore National Laboratory.

Rose, T.P., D.K. Smith, and D.L. Phinney. 2000a. "Secondary Ion Mass Spectrometry Measurements of Volcanic Tuffs Containing Radionuclides from Underground Nuclear Tests." In Radiochim. Acta, Vol. 88: 465 - 473. Munich, Germany: R. Oldenberg.

Rose, T.P., G.A. Pawloski, and D.K. Smith. 2000b. Environmentally Closed Test Cavity-Chimney Systems: Evidence and Controlling Factors. Livermore, CA: Lawrence Livermore National Laboratory. 
Rose, T.P., Benedict, F.C., Jr., Thomas, J.M., Sicke, W.S., Hershey, R.L., Paces, J.B., Farnham, I.M., and Peterman, Z.E. 2002. Geochemical Data Analysis and Interpretation of the Pahute Mesa-Oasis Valley Groundwater Flow System, Nye County, Nevada. Draft report submitted to U.S. Department of Energy, Nevada Operations Office, August.

Rose, T.P., G.F. Eaton, and A.B. Kersting, eds. 2003. Hydrologic Resources Management Program and Underground Test Area Project FY2001-2002 Progress Report, UCRL-ID-154357. Livermore, CA: Lawrence Livermore National Laboratory.

Russell, G.M., and G.I. Locke. 1997. Summary of Data Concerning Radiological contamination at Well PM-2, Nevada Test Site, Nye County, Nevada, USGS-OFR-96-599. Denver, CO: U.S. Geological Survey.

Smith, D.K. 1993. Review of Literature Pertaining to the Leaching and Sorption of Radionuclides Associated with Nuclear Explosive Melt Glasses, UCRL-ID-113370. Livermore, CA: Lawrence Livermore National Laboratory.

Smith, D.K. 1995a. Challenges in Defining a Radiologic and Hydrologic Source Term for Underground Nuclear Test Centers, Nevada Test Site, Nye County, Nevada, UCRL-JC-120389. Livermore, CA: Lawrence Livermore National Laboratory.

Smith, D.K. 1995b. Phenomenology of Underground Nuclear Explosions Conducted at the Nevada Test Site with Emphasis on Recent Experience at BASEBALL (U7ba) and INGOT (U2gg). Prepared for the U.S. Department of Energy, Nevada Operations Office. Livermore, CA: Lawrence Livermore National Laboratory.

Smith, D.K. 2001. Unclassified Radiologic Source Term for Nevada Test Site Areas 19 and 20, UCRL-ID-141706. Livermore, CA: Lawrence Livermore National Laboratory.

Smith, D.K. 2002. Evaluation of the Radiochemistry of Near-Field Water Samples at the Nevada Test Site Applied to the Definition of a Hydrologic Source Term, UCRL-ID-149049. Livermore, CA: Lawrence Livermore National Laboratory.

Smith, D.K., B.K. Esser, and J.L. Thompson. 1995. Uncertainties Associated with the Definition of a Hydrologic Source Term for the Nevada Test Site, UCRL-ID-120322. Livermore, CA: Lawrence Livermore National Laboratory.

Smith, D.K., Lawrence Livermore National Laboratory. 1997. Memo to Janet Wille (IT Corp.), regarding radionuclides recommended by the Underground Test Area-Source and Transport (UGTA-S\&T) Subcommittee of significance for remedial investigations at the Nevada Test Site. Livermore, CA. 
Smith, D.K., R.J. Nagle, and J.M. Kenneally. 1996. "Migration of Fission Products at the Nevada Test Site: Detection with an Isotopic Tracer." In Radiochim. Acta, 52/53: 229 - 231. Munich, Germany: R. Oldenberg.

Smith, D.K., A.B. Kersting, J.M. Kenneally, J.H. Rego, and J.L. Thompson. 1997. Hydrologic Resources Management Program FY 1996 Progress Report, UCRL-ID-126886. Livermore, CA: Livermore National Laboratory.

Smith, D.K., A.B. Kersting, T.P. Rose, J.M. Kenneally, G.B. Hudson, G.F. Eaton, and M.L. Davisson. 1998. Hydrologic Resources Management Program and Underground Test Area Operable Unit FY 1997 Progress Report, UCRL-ID-130792. Livermore, CA: Lawrence Livermore National Laboratory.

Smith, D.K., A.B. Kersting, T.P. Rose, J.M. Kenneally, G.B. Hudson, G.F. Eaton, M.L. Davisson, F.C. Benedict, Jr., and R.E. Criss. 1999. Hydrologic Resources Management Program and Underground Test Area, FY 1998 Progress Report, UCRL-ID-135170. Lawrence, CA: Lawrence Livermore National Laboratory.

Smith, D.K., G.F. Eaton, T.P. Rose, J.E. Moran, A. Brachmann, J.E. McAninch, A.B. Kersting, V.V. Romanovski, R.E. Martinelli, and J.K. Werner, Jr. 2000. Hydrologic Resources Management Program and Underground Test Area FY 1999 Progress Report, UCRL-ID-139226. Livermore, CA: Lawrence Livermore National Laboratory.

Smith, D.K. 2002. Evaluation of the Radiochemistry of Near-Field Water Samples at the Nevada Test Site Applied to the Definition of a Hydrologic Source Term, UCRL-ID-149049. Lawrence, CA: Lawrence Livermore National Laboratory.

Sobocinski, R.W., IT Corporation. 1997. Memorandum to files regarding Oasis Valley tritium data, 11 November. Las Vegas, NV: IT Corporation.

Stoller-Navarro Joint Venture. 2004. Hydrologic Data for the Groundwater Flow and Contaminant Transport Model of Corrective Action Units 101 and 102: Central and Western Pahute Mesa, Nye County, Nevada. Las Vegas, NV.

Thompson, J.L., ed. 1986. Laboratory and Field Studies Related to the Radionuclide Migration Project (October 1, 1984 - September 30, 1985), Progress Report LA-10644-PR. Los Alamos, NM: Los Alamos National Laboratory.

Thompson, J.L., ed. 1987. Laboratory and Field Studies Related to the Radionuclide Migration Project (October 1, 1985 - September 30, 1986), Progress Report LA-11081-PR. Los Alamos, NM: Los Alamos National Laboratory. 
Thompson, J.L., ed. 1988. Laboratory and Field Studies Related to the Radionuclide Migration Project (October 1, 1986 - September 30, 1987), Progress Report LA-11223-PR. Los Alamos, NM: Los Alamos National Laboratory.

Thompson, J.L. ed., 1995. Laboratory and Field Studies Related to the Hydrologic Resources Management Program (October 1, 1994 - September 30, 1995), LA-13064-PR. Los Alamos, NM: Los Alamos National Laboratory.

Thompson, J.L. ed. 1997. Laboratory and Field Studies Related to the Hydrologic Resources Management Program (October 1, 1995 - September 30, 1996), LA-13270-PR. Los Alamos, NM: Los Alamos National Laboratory.

Thompson, J.L. ed. 1998. Laboratory and Field Studies Related to Radionuclide Migration at the Nevada Test Site (October 1, 1996 - September 30, 1997), LA-13419-PR. Los Alamos, NM: Los Alamos National Laboratory.

Thompson, J.L. ed. 1999. Laboratory and Field Studies Related to Radionuclide Migration at the Nevada Test Site (October 1, 1997 - September 30, 1998), LA-13576-PR. Los Alamos, NM: Los Alamos National Laboratory.

Thompson, J.L., ed. 2000. Laboratory and Field Studies Related to Radionuclide Migration of the Nevada Test Site, October 1, 1998-September 30, 1999, LA-13701-PR. Los Alamos, NM: Los Alamos National Laboratory.

Thompson, J.L., and J.S. Gilmore. 1991. "Migration of Fission Products at the Nevada Test Site: Detection with an Isotopic Tracer." In Radiochim. Acta, Vol. 52/53: 229-231. Munich, Germany: R. Oldengerg.

Tompson, A.F.B., C.J. Bruton, and G.A. Pawloski (eds.). 1999. Evaluation of the Hydrologic Source Term from Underground Nuclear Tests in Frenchman Flat at the Nevada Test Site: The CAMBRIC Test, UCRL-ID-132300. Livermore, CA: Lawrence Livermore National Laboratory.

Tompson, A.F.B., M. Zavarin, C.J. Bruton, and G.A. Pawloski. 2004. Simplified Hydrologic Source Term for Frenchman Flat Sensitivity Studies, UCRL-TR-201817. Livermore, CA: Lawrence Livermore National Laboratory.

U.S. Congress, Office of Technology Assessment. 1989. The Containment of Underground Explosions. Washington, DC: U.S. Government Printing Office.

U.S. Department of Energy. 2000. Quality Assurance Requirements and Description, DOE/RW-0333P, Rev. 10. Washington, DC: U.S. Department of Energy, Office of Civilian Radioactive Waste Management. ACC:MOL.20000427.0422. 
U.S. Department of Energy, Nevada Operations Office. 1997a. Completion Report for Well Cluster ER-20-5, DOE/NV-466. Las Vegas, NV.

U.S. Department of Energy, Nevada Operations Office. 1997b. Regional Groundwater Flow and Tritium Transport Modeling and Risk Assessment of the Underground Test Area, Nevada Test Site, Nevada, DOE/NV-477. Las Vegas, NV.

U.S. Department of Energy, Nevada Operations Office. 1998. Completion Report for Well Cluster ER-20-6, DOE/NV-467. Las Vegas, NV.

U.S. Department of Energy, Nevada Operations Office. 1999. Corrective Action Investigation Plan for Corrective Action Units 101 and 102, Central and Western Pahute Mesa, Nevada Test Site, Nevada, DOE/NV-516, Rev. 1. Las Vegas, NV.

U.S. Department of Energy, Nevada Operations Office. 2000. United States Nuclear Tests, July 1945 through September 1992, DOE/NV--209, Rev. 15. Las Vegas, NV.

Watermark Computing, see Watermark Numerical Computing and Waterloo Hydrogeologic.

Watermark Numerical Computing and Waterloo Hydrogeologic. 2000. Visual PEST User's Manual (Includes PEST2000 \& WinPEST) - Graphical Model-Independent Parameter Estimation. Ontario, Canada, and Tampa, FL.

Wolfsberg, A., L. and J. Boryta. 2002. Extension to TYBO/BENHAM Modeling Study: Additional Radionuclide and Transport Processes. Los Alamos, NM: Los Alamos National Laboratory.

Wolfsberg, A., L. Glascoe, G. Lu, A. Olson, P. Lichtner, M. McGraw, T. Cherry, and G. Roemer. 2002. TYBO/BENHAM Model Analysis of Groundwater Flow and Radionuclide Migration from Underground Nuclear Tests in Southwestern Pahute Mesa, NTS, LA-13977. Los Alamos, NM: Los Alamos National Laboratory.

Zyvoloski, G.A., B.A. Robinson, Z.V. Dash, and L.L. Trease. 1997a. Summary of Models and Methods for the FEHM Application - A Finite-Element Heatand Mass-Transfer Code, LA-13307-MS. Los Alamos, NM: Los Alamos National Laboratory.

Zyvoloski, G.A., B.A. Robinson, Z.V. Dash, and L.L. Trease. 1997b. User's Manual for the FEHM Application - A Finite-Element Heat- and Mass-Transfer Code, LA-13306-M. Los Alamos, NM: Los Alamos National Laboratory. 
Appendix A

Hydrostratigraphic Model Supporting Information 


\section{A.1.0 Description of the Pahute Mesa-Oasis Valley Model Layers}

Brief descriptions of the HSUs used to construct the PM-OV model are provided in Table A.1-1. They are listed in approximate order from surface to basement, although some are laterally rather than vertically contiguous, and not all units are present in all parts of the model area. Other information supporting Table A.1-1 is provided in Table A.1-2 and Table A.1-3.

\section{A.2.0 References}

Bechtel Nevada. 2002. Hydrostratigraphic Model of the Pahute Mesa-Oasis Valley Area, Nye County, Nevada, DOE/NV/11718-646. Prepared for U.S. Department of Energy, National Nuclear Security Administration Nevada Operations Office. Las Vegas, NV.

Ferguson, J.F., A.H. Cogbill, and R.G. Warren. 1994. "A GeophysicalGeological Transect of the Silent Canyon Caldera Complex, Pahute Mesa, Nevada.” In Groundwater, Vol. 99 (B3): 4323-4339. Washington, DC: American Geophysical Union.

IT Corporation. 1996. Regional Geologic Model Data Documentation Package (Phase 1 Data Analysis Documentation, Volume I). Prepared for the U.S. Department of Energy, Nevada Operations Office. Las Vegas, NV.

Slate, J.L., M.E. Berry, P.D. Rowley, C.J. Fridrich, K.S. Morgan, J.B. Workman, O.D. Young, G.L. Dixon, V.S. Williams, E.H. McKee, D.A. Ponce, T.G. Hildenbrand, WC Swadley, S.C. Lundstrom, E.B. Ekren, R.G. Warren, J.C. Cole, R.J. Fleck, M.A. Lanphere, D.A. Sawyer, S.A. Minor, D.J. Grunwald, R.J. Laczniak, C.M. Menges, J.C. Yount, and A.S. Jayko. 1999. Digital Geologic Map of the Nevada Test Site and Vicinity, Nye, Lincoln, and Clark Counties, Nevada, and Inyo County, California, USGS-OFR-99-554-A. Denver, CO: U.S. Geological Survey. 
Table A.1-1

Hydrostratigraphic Units of the Pahute Mesa-Oasis Valley Hydrostratigraphic Framework Model

(Page 1 of 6 )

\begin{tabular}{|c|c|c|c|c|c|}
\hline $\begin{array}{l}\text { Model Layer } \\
\text { Number }^{a}\end{array}$ & $\begin{array}{c}\text { Hydrostratigraphic Unit } \\
\text { (Symbol) }\end{array}$ & $\begin{array}{l}\text { Dominant } \\
\text { Hydrogeologic } \\
\text { Unit(s) }\end{array}$ & $\begin{array}{l}\text { Stratigraphic Unit } \\
\text { Map Symbols }^{c}\end{array}$ & General Description & $\begin{array}{l}\text { Transport } \\
\text { Parameter } \\
\text { Category }\end{array}$ \\
\hline 46 & $\begin{array}{l}\text { Alluvial Aquifer (AA) } \\
\text { (this term is also used to } \\
\text { designate a hydrogeologic } \\
\text { unit) }\end{array}$ & AA & $\begin{array}{l}\text { Qay, QTc, Qs, Qam, } \\
\text { QTa, QTu, Qb, Tgy, } \\
\text { Tgc, Tgm, Tgyx, Tt }\end{array}$ & $\begin{array}{l}\text { Consists mainly of alluvium that fills extensional basins such as Gold Flat, } \\
\text { Crater Flat, Kawich Valley, and Sarcobatus Flat. Also includes generally } \\
\text { older Tertiary gravels, tuffaceous sediments, and nonwelded tuffs (where } \\
\text { thin) that partially fill other basins such as Oasis Valley and the moat of } \\
\text { the Timber Mountain caldera complex. }\end{array}$ & Alluvium \\
\hline 45 & $\begin{array}{l}\text { Younger Volcanic } \\
\text { Composite Unit } \\
\text { (YVCM) }\end{array}$ & LFA, WTA, VTA & $\begin{array}{l}\text { Typ, Tgy, Ts, Tyb, } \\
\text { Tyr }\end{array}$ & $\begin{array}{l}\text { A minor unsaturated HSU that consists of Pliocene to late Miocene } \\
\text { basaltic rocks such as those at Thirsty Mountain and Buckboard Mesa. } \\
\text { Also includes welded and nonwelded ash-flow tuff of the Volcanics of } \\
\text { Stonewall Mountain. Mainly occurs in the northwestern portion of the } \\
\text { model area. }\end{array}$ & $\begin{array}{l}\text { WTA } 75 \% \\
\text { VTA } 25 \%\end{array}$ \\
\hline 44 & $\begin{array}{l}\text { Thirsty Canyon Volcanic } \\
\text { Aquifer } \\
\text { (TCVA) }\end{array}$ & WTA, LFA, lesser VTA & $\begin{array}{l}\text { Ttg, Tth, Tts, Ttt, } \\
\text { Ttp, Ttc }\end{array}$ & $\begin{array}{l}\text { Consists mainly of welded ash-flow tuff and lava of the Thirsty Canyon } \\
\text { Group. Unit is very thick within the Black Mountain caldera. Also is } \\
\text { present east and south of the caldera, including the northwestern moat } \\
\text { area of the Timber Mountain caldera complex and the northern portion of } \\
\text { the Oasis Valley basin. }\end{array}$ & $\begin{array}{l}\text { WTA } 75 \% \\
\text { LFA } 25 \%\end{array}$ \\
\hline 43 & $\begin{array}{l}\text { Detached Volcanics } \\
\text { Composite Unit } \\
\text { (DVCM) }\end{array}$ & WTA, LFA, TCU & Tf through Tq & $\begin{array}{l}\text { Consists of a very complex distribution of lavas and tuffs that form a } \\
\text { relatively thin, highly extended interval above the FC-BH detachment fault } \\
\text { in the southwestern portion of the model area. }\end{array}$ & $\begin{array}{l}\text { WTA } 85 \% \\
\text { TCU } 15 \%\end{array}$ \\
\hline 42 & $\begin{array}{l}\text { Detached Volcanics } \\
\text { Aquifer } \\
\text { (DVA) }\end{array}$ & WTA, LFA & Tgyx, Tf, Tma, Tmr & $\begin{array}{l}\text { Consists of welded ash-flow tuff and lava assigned to the Ammonia Tanks } \\
\text { Tuff and units of the Volcanics of Fortymile Canyon. Although (like the } \\
\text { DVCM) the DVA also overlies the FC-BH detachment fault, it is } \\
\text { considered a separate HSU because of the preponderance of welded-tuff } \\
\text { and lava-flow aquifers that compose the HSU and much smaller degree of } \\
\text { alteration present. }\end{array}$ & WTA \\
\hline 41 & $\begin{array}{l}\text { Fortymile Canyon } \\
\text { Composite Unit } \\
\text { (FCCM) }\end{array}$ & LFA, TCU, lesser WTA & $\begin{array}{l}\text { Tfu, Tfs, Tfd, Tfr, } \\
\text { Tfb, Tfl, Tff }\end{array}$ & $\begin{array}{l}\text { Consists of a complex and poorly understood distribution of lava and } \\
\text { associated tuff of the Volcanics of Fortymile Canyon. Generally confined } \\
\text { within the moat of the Timber Mountain caldera complex, where the unit } \\
\text { forms a ring around Timber Mountain. Unit is also present in areas } \\
\text { southwest of the Timber Mountain caldera complex. }\end{array}$ & $\begin{array}{l}\text { LFA } 60 \% \\
\text { TCU } 30 \% \\
\text { WTA } 10 \%\end{array}$ \\
\hline 40 & $\begin{array}{l}\text { Fortymile Canyon } \\
\text { Aquifer } \\
\text { (FCA) }\end{array}$ & WTA, LFA & $\begin{array}{l}\text { Tff, tuff of Cutoff } \\
\text { Road }\end{array}$ & $\begin{array}{l}\text { Composed mainly of welded ash-flow tuffs and lesser amounts of rhyolitic } \\
\text { lava, and is generally less than } 305 \mathrm{~m}(1,000 \mathrm{ft}) \text { thick. It is located } \\
\text { between two composite units that are much more hydrologically diverse, } \\
\text { although they include some of the same units as the FCA. The FCA is } \\
\text { completely saturated. }\end{array}$ & $\begin{array}{l}\text { WTA } 80 \% \\
\text { LFA } 20 \%\end{array}$ \\
\hline
\end{tabular}


Table A.1-1

Hydrostratigraphic Units of the Pahute Mesa-Oasis Valley Hydrostratigraphic Framework Model

(Page 2 of 6 )

\begin{tabular}{|c|c|c|c|c|c|}
\hline $\begin{array}{l}\text { Model Layer } \\
\text { Number }^{\mathrm{a}}\end{array}$ & $\begin{array}{l}\text { Hydrostratigraphic Unit } \\
\text { (Symbol) }\end{array}$ & $\begin{array}{l}\text { Dominant } \\
\text { Hydrogeologic } \\
\text { Unit(s) }\end{array}$ & $\begin{array}{l}\text { Stratigraphic Unit } \\
\text { Map Symbols }\end{array}$ & General Description & $\begin{array}{l}\text { Transport } \\
\text { Parameter } \\
\text { Category }\end{array}$ \\
\hline 39 & $\begin{array}{l}\text { Timber Mountain } \\
\text { Composite Unit } \\
\text { (TMCM) }\end{array}$ & $\begin{array}{l}\text { TCU (altered tuffs, } \\
\text { lavas) and unaltered } \\
\text { WTA and lesser LFA }\end{array}$ & $\begin{array}{l}\text { Tmay, Tmaw, Tma, } \\
\text { Tmx, Tmat, Tmt, } \\
\text { Tmr }\end{array}$ & $\begin{array}{l}\text { Consists mainly of intra-caldera, strongly welded ash-flow tuff of the } \\
\text { Timber Mountain Group, and is confined within the Timber Mountain } \\
\text { caldera complex. Although consisting mainly of strongly welded tuff which } \\
\text { is assumed to be considerably fractured and thus behave as an aquifer, } \\
\text { the TMCM is designated a composite unit because of the potential for } \\
\text { hydrothermal alteration within this deep intra-caldera setting. Alteration } \\
\text { would have significantly altered the hydraulic properties of the rocks, } \\
\text { particularly filling fractures with secondary minerals such as quartz. }\end{array}$ & $\begin{array}{l}\text { TCU } 75 \% \\
\text { WTA } 25 \%\end{array}$ \\
\hline 38 & $\begin{array}{l}\text { Tannenbaum Hill Lava-Flow } \\
\text { Aquifer } \\
\text { (THLFA) }\end{array}$ & LFA & Tmat & $\begin{array}{l}\text { Composed entirely of rhyolitic lava of the rhyolite of Tannenbaum Hill. } \\
\text { Occurs just outside the northwestern structural boundary of the Timber } \\
\text { Mountain caldera complex. Tannenbaum Hill lava occurring inside the } \\
\text { caldera complex is grouped with the TMCM. }\end{array}$ & LFA \\
\hline 37 & $\begin{array}{l}\text { Tannenbaum Hill } \\
\text { Composite Unit } \\
\text { (THCM) }\end{array}$ & $\begin{array}{l}\text { Mostly TCU, } \\
\text { lesser WTA }\end{array}$ & Tmat & $\begin{array}{l}\text { Zeolitic tuff and lesser welded ash-flow tuff of the rhyolite of Tannenbaum } \\
\text { Hill that occurs stratigraphically below Tannenbaum Hill lava and above } \\
\text { the rhyolite of Fluorspar Canyon. Distribution is similar to the THLFA. }\end{array}$ & $\begin{array}{l}\text { TCU } 75 \% \\
\text { WTA } 25 \%\end{array}$ \\
\hline 36 & $\begin{array}{l}\text { Timber Mountain } \\
\text { Aquifer } \\
\text { (TMA) }\end{array}$ & $\begin{array}{l}\text { Mostly WTA, } \\
\text { minor VTA }\end{array}$ & $\begin{array}{l}\text { Tmay, Tmaw, Tma, } \\
\text { Tmx, Tmat, Tmt, } \\
\text { Tmr }\end{array}$ & $\begin{array}{l}\text { Consists mainly of extra-caldera welded ash-flow tuffs of Ammonia Tanks } \\
\text { Tuff and Rainier Mesa Tuff. These rocks are the extra-caldera equivalent } \\
\text { of the rocks comprising the TMCM. Unit occurs mostly north and west of } \\
\text { the Timber Mountain caldera complex. }\end{array}$ & $\begin{array}{c}\text { WTA } 80 \% \text { VTA } \\
20 \%\end{array}$ \\
\hline 35 & $\begin{array}{l}\text { Subcaldera Volcanic } \\
\text { Confining Unit } \\
\text { (SCVCU) }\end{array}$ & TCU & $\begin{array}{l}\text { Tm, Tp, Tc, and } \\
\text { older, } \\
\text { undifferentiated tuffs }\end{array}$ & $\begin{array}{l}\text { A highly conjectural unit that is modeled as consisting of highly altered } \\
\text { volcanic rocks that occur stratigraphically between the Rainier Mesa Tuff } \\
\text { and basement rocks (ATICU and RMICU) within the deeper portions of } \\
\text { the Timber Mountain caldera complex. }\end{array}$ & TCU \\
\hline 34 & $\begin{array}{l}\text { Fluorspar Canyon } \\
\text { Confining Unit } \\
\text { (FCCU) }\end{array}$ & TCU & Tmrf & $\begin{array}{l}\text { Consists of zeolitic, nonwelded tuff of the rhyolite of Fluorspar Canyon } \\
\text { that generally occurs beneath the THCM, and thus has a similar } \\
\text { distribution. Typically, the rhyolite of Fluorspar Canyon is higher } \\
\text { structurally, and vitric in other areas. }\end{array}$ & TCU \\
\hline 33 & $\begin{array}{l}\text { Windy Wash Aquifer } \\
\text { (WWA) }\end{array}$ & LFA & Tmw & $\begin{array}{l}\text { Minor HSU consisting of the lava-flow lithofacies of the rhyolite of Windy } \\
\text { Wash. Occurs along the western (down-thrown) side of the West Greeley } \\
\text { fault in Area } 20 \text {. }\end{array}$ & LFA \\
\hline
\end{tabular}


Table A.1-1

Hydrostratigraphic Units of the Pahute Mesa-Oasis Valley Hydrostratigraphic Framework Model

(Page 3 of 6 )

\begin{tabular}{|c|c|c|c|c|c|}
\hline $\begin{array}{l}\text { Model Layer } \\
\text { Number }^{a}\end{array}$ & $\begin{array}{l}\text { Hydrostratigraphic Unit } \\
\text { (Symbol) }\end{array}$ & $\begin{array}{l}\text { Dominant } \\
\text { Hydrogeologic } \\
\text { Unit(s) }\end{array}$ & $\begin{array}{l}\text { Stratigraphic Unit } \\
\text { Map Symbols }^{c}\end{array}$ & General Description & $\begin{array}{l}\text { Transport } \\
\text { Parameter } \\
\text { Category }\end{array}$ \\
\hline 32 & $\begin{array}{l}\text { Paintbrush } \\
\text { Composite Unit } \\
\text { (PCM) }\end{array}$ & WTA, LFA, TCU & Tmr, Tmrf, Tmn, Tp & $\begin{array}{l}\text { Consists mostly of units of the Paintbrush Group that occur in the } \\
\text { southern portion of the model area in the vicinity of the Claim Canyon } \\
\text { caldera. Unit is dominated by thick, strongly welded Tiva Canyon Tuff } \\
\text { within the Claim Canyon caldera. Outside the caldera this unit is more } \\
\text { variable, consisting of welded and nonwelded tuff and rhyolitic lava } \\
\text { assigned to various formations of the Paintbrush Group. Stratigraphically } \\
\text { equivalent units of the Paintbrush Group that occur in the northern portion } \\
\text { of the model area beneath Pahute Mesa have been grouped into seven } \\
\text { separate HSUs. }\end{array}$ & $\begin{array}{l}\text { WTA } 75 \% \\
\text { TCU } 25 \%\end{array}$ \\
\hline 31 & $\begin{array}{l}\text { Paintbrush } \\
\text { Vitric-tuff Aquifer } \\
\text { (PVTA) }\end{array}$ & VTA & Pre-Tmr tuffs, Tp & $\begin{array}{l}\text { Typically includes all vitric, nonwelded, and bedded tuff units below the } \\
\text { Rainier Mesa Tuff to the top of a Paintbrush lava (e.g., Tpb or Tpe) but } \\
\text { may extend to base of Paintbrush Tuff in eastern Area } 19 \text { where Tpe or } \\
\text { Tpr lavas are not present. May also include the vitric pumiceous top of } \\
\text { the Tpe lava. Unit occurs in the northern portion of the model area } \\
\text { beneath Pahute Mesa. }\end{array}$ & VTA \\
\hline 30 & $\begin{array}{l}\text { Benham Aquifer } \\
\text { (BA) }\end{array}$ & LFA & $\mathrm{Tpb}$ & $\begin{array}{l}\text { Lava-flow lithofacies of the rhyolite of Benham. Occurs north of the } \\
\text { Timber Mountain caldera complex and beneath the southwestern portion } \\
\text { of Pahute Mesa. }\end{array}$ & LFA \\
\hline 29 & $\begin{array}{l}\text { Upper Paintbrush } \\
\text { Confining Unit } \\
\text { (UPCU) }\end{array}$ & TCU & Pre-Tmr tuffs, Tp & $\begin{array}{l}\text { Includes all zeolitic, nonwelded and bedded tuffs below the Rainier Mesa } \\
\text { Tuff to base of the rhyolite of Delirium Canyon. Unit occurs in the northern } \\
\text { portion of the model area beneath Pahute Mesa. }\end{array}$ & TCU \\
\hline 28 & $\begin{array}{l}\text { Tiva Canyon Aquifer } \\
\text { (TCA) }\end{array}$ & WTA & Tpc & $\begin{array}{l}\text { The welded ash flow lithofacies of the Tiva Canyon Tuff in southern Area } \\
20 \text {. May not be differentiated where thin or where sandwiched between } \\
\text { vitric bedded tuffs as in Area } 19 .\end{array}$ & $\begin{array}{l}\text { WTA } 70 \% \\
\text { VTA } 30 \%\end{array}$ \\
\hline 27 & $\begin{array}{l}\text { Paintbrush } \\
\text { Lava-flow Aquifer } \\
\text { (PLFA) }\end{array}$ & LFA & Tpd, Tpe, Tpr & $\begin{array}{l}\text { Lava-flow lithofacies of the rhyolite of Delirium Canyon (Tpd), rhyolite of } \\
\text { Echo Peak (Tpe), and rhyolite of Silent Canyon (Tpr). Also includes } \\
\text { moderately to densely welded ash-flow tuff of Tpe. Unit occurs in the } \\
\text { northern portion of the model area beneath Pahute Mesa. }\end{array}$ & LFA \\
\hline 26 & $\begin{array}{l}\text { Lower Paintbrush } \\
\text { Confining Unit } \\
\text { (LPCU) }\end{array}$ & TCU & Tpe, Tpp, Tpt & $\begin{array}{l}\text { Includes all zeolitic nonwelded and bedded tuffs below the rhyolite of } \\
\text { Delirium Canyon to the base of the Topopah Spring Tuff. Unit occurs in } \\
\text { the northern portion of the model area beneath Pahute Mesa. }\end{array}$ & TCU \\
\hline 25 & $\begin{array}{l}\text { Topopah Spring Aquifer } \\
\text { (TSA) }\end{array}$ & WTA & Tpt & $\begin{array}{l}\text { The welded ash-flow lithofacies of the Topopah Spring Tuff in southern } \\
\text { Area } 20 .\end{array}$ & WTA \\
\hline
\end{tabular}


Table A.1-1

Hydrostratigraphic Units of the Pahute Mesa-Oasis Valley Hydrostratigraphic Framework Model

(Page 4 of 6 )

\begin{tabular}{|c|c|c|c|c|c|}
\hline $\begin{array}{l}\text { Model Layer } \\
\text { Number }^{\mathrm{a}}\end{array}$ & $\begin{array}{l}\text { Hydrostratigraphic Unit } \\
\text { (Symbol) }\end{array}$ & $\begin{array}{l}\text { Dominant } \\
\text { Hydrogeologic } \\
\text { Unit(s) }\end{array}$ & $\begin{array}{l}\text { Stratigraphic Unit } \\
\text { Map Symbols }\end{array}$ & General Description & $\begin{array}{l}\text { Transport } \\
\text { Parameter } \\
\text { Category }\end{array}$ \\
\hline 24 & $\begin{array}{l}\text { Yucca Mountain Crater } \\
\text { Flat Composite Unit } \\
\text { (YMCFCM) }\end{array}$ & LFA, WTA, TCU & Tc, Th & $\begin{array}{l}\text { Includes all units of the Crater Flat Group and Calico Hills Formation that } \\
\text { occur in the southern portion of the model area in the vicinity of Yucca } \\
\text { Mountain. Stratigraphically equivalent units that occur in the northern } \\
\text { portion of the model area beneath Pahute Mesa have been grouped into } \\
\text { nine separate HSUs. }\end{array}$ & $\begin{array}{l}\text { WTA } 75 \% \\
\text { TCU } 25 \%\end{array}$ \\
\hline 23 & $\begin{array}{l}\text { Calico Hills } \\
\text { Vitric-tuff Aquifer } \\
\text { (CHVTA) }\end{array}$ & VTA & Th (Tac) & $\begin{array}{l}\text { Structurally high, vitric, nonwelded tuffs of the Calico Hills Formation. } \\
\text { Present in the northern portion of the model area beneath the eastern } \\
\text { portion of Area 19. May become partly zeolitic in the lower portions. }\end{array}$ & VTA \\
\hline 22 & $\begin{array}{l}\text { Calico Hills } \\
\text { Vitric Composite Unit } \\
\text { (CHVCM) }\end{array}$ & VTA, LFA & Th & $\begin{array}{l}\text { Structurally high, lava and vitric nonwelded tuff of the Calico Hills } \\
\text { formation. Present in the northern portion of the model area beneath the } \\
\text { western portion of Area 19. May become partly zeolitic in the lower } \\
\text { portions. }\end{array}$ & $\begin{array}{l}\text { VTA } 75 \% \\
\text { LFA } 25 \%\end{array}$ \\
\hline 21 & $\begin{array}{l}\text { Calico Hills zeolitic composite } \\
\text { unit } \\
\text { (CHZCM) }\end{array}$ & LFA, TCU & Th & $\begin{array}{l}\text { Complex three-dimensional distribution of rhyolite lava and zeolitic } \\
\text { nonwelded tuff of the Calico Hills Formation. Present in the northern } \\
\text { portion of the model area beneath most of eastern and central Area } 20 \text {. }\end{array}$ & $\begin{array}{l}\text { TCU } 75 \% \\
\text { LFA } 25 \%\end{array}$ \\
\hline 20 & $\begin{array}{l}\text { Calico Hills } \\
\text { Confining Unit } \\
\text { (CHCU) }\end{array}$ & Mostly TCU, minor LFA & Th & $\begin{array}{l}\text { Consists mainly of zeolitic nonwelded tuff of the Calico Hills Formation. } \\
\text { May include minor lava flows along the eastern margin. Present in the } \\
\text { northern portion of the model area beneath the western portion of Area } \\
20 \text {. }\end{array}$ & $\begin{array}{l}\text { TCU } 90 \% \\
\text { LFA } 10 \%\end{array}$ \\
\hline 19 & $\begin{array}{l}\text { Inlet Aquifer } \\
\text { (IA) }\end{array}$ & LFA & Tci & $\begin{array}{l}\text { Lava-flow lithofacies of the rhyolite of Inlet. Occurs as two thick isolated } \\
\text { deposits beneath Pahute Mesa in the northern portion of the model area. }\end{array}$ & LFA \\
\hline 18 & $\begin{array}{l}\text { Crater Flat } \\
\text { Composite Unit } \\
\text { (CFCM) }\end{array}$ & $\begin{array}{l}\text { Mostly LFA, intercalated } \\
\text { with TCU }\end{array}$ & Th (Tac), Tc & $\begin{array}{l}\text { Includes welded tuff and lava flow lithofacies of the tuff of Jorum (Tcpj), } \\
\text { the rhyolite of Sled (Tcps), and the andesite of Grimy Gulch (Tcg). Occurs } \\
\text { in central Area } 20 \text { in the northern portion of the model area. }\end{array}$ & $\begin{array}{l}\text { LFA } 75 \% \\
\text { TCU } 25 \%\end{array}$ \\
\hline 17 & $\begin{array}{l}\text { Crater Flat } \\
\text { Confining Unit } \\
\text { (CFCU) }\end{array}$ & TCU & Tc & $\begin{array}{l}\text { Includes all zeolitic, nonwelded and bedded units below the Calico Hills } \\
\text { Formation (Th) to the top of the Bullfrog Tuff (Tcb). Occurs mainly in Area } \\
19 \text { in the northern portion of the model area. }\end{array}$ & TCU \\
\hline 16 & $\begin{array}{l}\text { Kearsarge Aquifer } \\
\text { (KA) }\end{array}$ & LFA & Tcpk & $\begin{array}{l}\text { Minor HSU that consists of the lava-flow lithofacies of rhyolite of } \\
\text { Kearsarge. Unit is present as a small isolated occurrence in the } \\
\text { northeastern portion of the model area. }\end{array}$ & LFA \\
\hline 15 & $\begin{array}{l}\text { Bullfrog Confining Unit } \\
\text { (BCU) }\end{array}$ & TCU & Tcb & $\begin{array}{l}\text { Major confining unit in the northern portion of the model area. Unit } \\
\text { consists of thick intra-caldera, zeolitic, mostly nonwelded tuff of the } \\
\text { Bullfrog Formation. }\end{array}$ & TCU \\
\hline
\end{tabular}


Table A.1-1

Hydrostratigraphic Units of the Pahute Mesa-Oasis Valley Hydrostratigraphic Framework Model

(Page 5 of 6 )

\begin{tabular}{|c|c|c|c|c|c|}
\hline $\begin{array}{l}\text { Model Layer } \\
\text { Number }^{a}\end{array}$ & $\begin{array}{l}\text { Hydrostratigraphic Unit } \\
\text { (Symbol) }\end{array}$ & $\begin{array}{l}\text { Dominant } \\
\text { Hydrogeologic } \\
\text { Unit(s) }\end{array}$ & $\begin{array}{l}\text { Stratigraphic Unit } \\
\text { Map Symbols }\end{array}$ & General Description & $\begin{array}{c}\text { Transport } \\
\text { Parameter } \\
\text { Category }\end{array}$ \\
\hline 14 & $\begin{array}{l}\text { Belted Range Aquifer } \\
\text { (BRA) }\end{array}$ & $\begin{array}{l}\text { LFA and WTA, with } \\
\text { lesser TCU }\end{array}$ & $\mathrm{Tb}$ & $\begin{array}{l}\text { Consists of welded ash-flow tuff and lava of the Belted Range Group (Tb) } \\
\text { above the Grouse Canyon Tuff (Tbg), but may also include the lava flow } \\
\text { lithofacies of the commendite of Split Ridge (Tbgs) and the commendite of } \\
\text { Quartet Dome (Tbq) where present. Occurs in the northern portion of the } \\
\text { model area. }\end{array}$ & $\begin{array}{l}\text { WTA } 50 \% \\
\text { LFA } 50 \%\end{array}$ \\
\hline 13 & $\begin{array}{l}\text { Pre-belted Range } \\
\text { Composite Unit } \\
\text { (PBRCM) }\end{array}$ & TCU, WTA, LFA & $\begin{array}{l}\text { Tr, Tn, Tq, Tu, To, } \\
\text { Tk, Te }\end{array}$ & $\begin{array}{l}\text { Laterally extensive and locally very thick HSU that includes all the } \\
\text { volcanic rocks older than the Belted Range Group. }\end{array}$ & $\begin{array}{l}\text { TCU } 75 \% \\
\text { WTA } 25 \%\end{array}$ \\
\hline 12 & $\begin{array}{l}\text { Black Mountain } \\
\text { Intrusive Confining Unit } \\
\text { (BMICU) }\end{array}$ & $\mathrm{IICU}$ & Tti & \multirow{6}{*}{$\begin{array}{l}\text { Although modeled as single intrusive masses beneath each of the Black } \\
\text { Mountain, Ammonia Tanks, Rainier Mesa, Claim Canyon, and Silent } \\
\text { Canyon calderas, and the Calico Hills area, the actual nature of these } \\
\text { units is unknown. They may consist exclusively of igneous intrusive } \\
\text { rocks, or older volcanic and pre-Tertiary sedimentary rocks that are } \\
\text { intruded to varying degrees by igneous rocks ranging in composition from } \\
\text { granite to basalt. }\end{array}$} & \multirow[t]{6}{*}{ “TCU” } \\
\hline 11 & $\begin{array}{l}\text { Ammonia Tanks } \\
\text { Intrusive Confining Unit } \\
\text { (ATICU) }\end{array}$ & $\mathrm{IICU}$ & Tmai & & \\
\hline 10 & $\begin{array}{l}\text { Rainier Mesa Intrusive } \\
\text { Confining Unit } \\
\text { (RMICU) }\end{array}$ & IICU & Tmri & & \\
\hline 9 & $\begin{array}{l}\text { Claim Canyon Intrusive } \\
\text { Confining Unit } \\
(\mathrm{CCICU})\end{array}$ & IICU & Tpi & & \\
\hline 8 & $\begin{array}{l}\text { Calico Hills Intrusive } \\
\text { Confining Unit } \\
\text { (CHICU) }\end{array}$ & $\mathrm{IICU}$ & Thi & & \\
\hline 7 & $\begin{array}{l}\text { Silent Canyon Intrusive } \\
\text { Confining Unit } \\
\text { (SCICU) }\end{array}$ & $\mathrm{IICU}$ & Tc, Tb & & \\
\hline 6 & $\begin{array}{l}\text { Mesozoic Granite } \\
\text { Confining Unit } \\
\text { (MGCU) }\end{array}$ & GCU & $\mathrm{Kg}$ & $\begin{array}{l}\text { Consists of granitic rocks that comprise the Gold Meadows stock along } \\
\text { the northeastern margin of the model area. }\end{array}$ & \\
\hline 5 & $\begin{array}{l}\text { Lower Carbonate Aquifer - } \\
\text { Thrust Plate } \\
\text { (LCA3) }\end{array}$ & $\mathrm{CA}$ & Dg through Cc & $\begin{array}{l}\text { Cambrian through Devonian, mostly limestone and dolomite, rocks that } \\
\text { occur in the hanging wall of the Belted Range thrust fault. }\end{array}$ & \\
\hline
\end{tabular}


Table A.1-1

Hydrostratigraphic Units of the Pahute Mesa-Oasis Valley Hydrostratigraphic Framework Model

(Page 6 of 6 )

\begin{tabular}{|c|c|c|c|c|c|}
\hline $\begin{array}{c}\text { Model Layer } \\
\text { Number }^{a}\end{array}$ & $\begin{array}{l}\text { Hydrostratigraphic Unit } \\
\text { (Symbol) }\end{array}$ & $\begin{array}{c}\text { Dominant } \\
\text { Hydrogeologic } \\
\text { Unit(s) }^{\mathrm{b}}\end{array}$ & $\begin{array}{l}\text { Stratigraphic Unit } \\
\text { Map Symbols }\end{array}$ & General Description & $\begin{array}{c}\text { Transport } \\
\text { Parameter } \\
\text { Category }\end{array}$ \\
\hline 4 & $\begin{array}{l}\text { Lower Clastic Confining Unit - } \\
\text { Thrust Plate } \\
\text { (LCCU1) }\end{array}$ & $\mathrm{CCU}$ & $\mathrm{Cc}, \mathrm{Cz}, \mathrm{Czw}, \mathrm{Zs}$ & $\begin{array}{l}\text { Late Proterozoic to Early Cambrian siliciclastic rocks that occur within the } \\
\text { hanging wall of the Belted Range thrust fault. }\end{array}$ & \\
\hline 3 & $\begin{array}{l}\text { Upper Clastic } \\
\text { Confining Unit } \\
\text { (UCCU) }\end{array}$ & $\mathrm{CCU}$ & MDc, MDe & $\begin{array}{l}\text { Late Devonian through Mississippian siliciclastic rocks. Present in the } \\
\text { eastern third of the model area. }\end{array}$ & \\
\hline 2 & $\begin{array}{l}\text { Lower Carbonate Aquifer } \\
\text { (LCA) }\end{array}$ & CA & Dg through Cc & $\begin{array}{l}\text { Cambrian through Devonian mostly limestone and dolomite. Widespread } \\
\text { throughout the model area. }\end{array}$ & \\
\hline 1 & $\begin{array}{l}\text { Lower Clastic } \\
\text { Confining Unit } \\
\text { (LCCU) }\end{array}$ & $\mathrm{CCU}$ & Cc, Cz, Czw, Zs, Zj & $\begin{array}{l}\text { Late Proterozoic through Early Cambrian siliciclastic rocks. Widespread } \\
\text { throughout the model area. }\end{array}$ & \\
\hline
\end{tabular}

aPM-OV 3-D Hydrostratigraphic Framework model (BN, 2002)

bSee Table A.1-2 and Table A.1-3 for definitions of HGUs

'Refer to Slate et al. (1999) and Ferguson et al. (1994) for definitions of stratigraphic unit map symbols

Adapted from BN, 2002 
Table A.1-2

Hydrogeologic Units of the UGTA Regional Model in the PM-OV Model Area

\begin{tabular}{|c|c|c|}
\hline Hydrogeologic Unit & Typical Lithologies & Hydrologic Significance \\
\hline $\begin{array}{l}\text { Alluvial aquifer } \\
\text { (AA) } \\
\text { (AA is also an HSU } \\
\text { in hydrogeologic models.) }\end{array}$ & $\begin{array}{l}\text { Unconsolidated to partially } \\
\text { consolidated gravelly sand, aeolian } \\
\text { sand, and colluvium; thin, basalt flows } \\
\text { of limited extent }\end{array}$ & $\begin{array}{l}\text { Has characteristics of a highly conductive aquifer, but less so } \\
\text { where lenses of clay-rich paleocolluvium or playa deposits are } \\
\text { present }\end{array}$ \\
\hline $\begin{array}{l}\text { Welded-tuff aquifer } \\
\text { (WTA) }\end{array}$ & Welded ash-flow tuff; vitric to devitrified & $\begin{array}{l}\text { Degree of welding greatly affects interstitial porosity (less porosity } \\
\text { as degree of welding increases) and permeability (greater fracture } \\
\text { permeability as degree of welding increases) }\end{array}$ \\
\hline $\begin{array}{l}\text { Vitric-tuff aquifer } \\
\text { (VTA) }\end{array}$ & $\begin{array}{l}\text { Bedded tuff; ash-fall and reworked tuff; } \\
\text { vitric }\end{array}$ & $\begin{array}{l}\text { Constitutes a volumetrically minor HGU; generally does not } \\
\text { extend far below the static water level due to tendency of tuffs to } \\
\text { become zeolitic (which drastically reduces permeability) under } \\
\text { saturated conditions; significant interstitial porosity ( } 20 \text { to } \\
40 \text { percent); generally insignificant fracture permeability }\end{array}$ \\
\hline $\begin{array}{l}\text { Lava-flow aquifer } \\
\text { (LFA) }\end{array}$ & $\begin{array}{l}\text { Rhyolite lava flows; includes flow } \\
\text { breccias (commonly at base) and } \\
\text { pumiceous zones (commonly at top) }\end{array}$ & $\begin{array}{l}\text { Generally a caldera-filling unit; hydrologically complex, wide } \\
\text { range of transmissivities, fracture density and interstitial porosity } \\
\text { differ with lithologic variations }\end{array}$ \\
\hline $\begin{array}{l}\text { Tuff confining unit } \\
\text { (TCU) }\end{array}$ & $\begin{array}{l}\text { Zeolitic bedded tuff with interbedded, } \\
\text { but less significant, zeolitic, nonwelded } \\
\text { to partially welded ash-flow tuff }\end{array}$ & $\begin{array}{l}\text { May be saturated but measured transmissivities are very low; } \\
\text { may cause accumulation of perched and/or semiperched water in } \\
\text { overlying units }\end{array}$ \\
\hline $\begin{array}{l}\text { Intrusive confining unit } \\
\text { (ICU) }\end{array}$ & Granodiorite, quartz monzonite & $\begin{array}{l}\text { Relatively impermeable; forms local bulbous stocks, north of } \\
\text { Rainier Mesa, Yucca Flat, and scattered elsewhere in the regional } \\
\text { model area; may contain perched water }\end{array}$ \\
\hline $\begin{array}{l}\text { Clastic confining unit } \\
(\mathrm{CCU})\end{array}$ & Argillite, siltstone, quartzite & $\begin{array}{l}\text { Clay-rich rocks are relatively impermeable; more siliceous rocks } \\
\text { are fractured, but with fracture porosity generally sealed due to } \\
\text { secondary mineralization }\end{array}$ \\
\hline $\begin{array}{l}\text { Carbonate aquifer } \\
(\mathrm{CA})\end{array}$ & Dolomite, limestone & $\begin{array}{l}\text { Transmissivity values vary greatly and are directly dependent on } \\
\text { fracture frequency }\end{array}$ \\
\hline
\end{tabular}

Source: Adapted from IT (1996) and BN (2002)

Table A.1-3

Additional and Modified Hydrogeologic Units of the PM-OV Model

\begin{tabular}{||l|l|l|}
\hline \multicolumn{1}{|c|}{ Hydrogeologic Unit } & \multicolumn{1}{|c|}{ Typical Lithologies } & \multicolumn{1}{c|}{ Hydrologic Significance } \\
\hline \hline $\begin{array}{l}\text { Intra-caldera intrusive } \\
\text { confining unit } \\
\text { (IICU) }\end{array}$ & $\begin{array}{l}\text { Highly altered, highly } \\
\text { injected/intruded country rock } \\
\text { and granitic material }\end{array}$ & $\begin{array}{l}\text { Assumed to be impermeable. Conceptually } \\
\text { underlies each of the SWNVF calderas and Calico } \\
\text { Hills. Developed for this study to designate } \\
\text { basement beneath calderas as different from } \\
\text { basement outside calderas. }\end{array}$ \\
\hline $\begin{array}{l}\text { Granite confining unit } \\
\text { (GCU) }\end{array}$ & $\begin{array}{l}\text { Granodiorite, quartz } \\
\text { monzonite }\end{array}$ & $\begin{array}{l}\text { Relatively impermeable; forms local bulbous stocks, } \\
\text { north of Rainier Mesa and Yucca Flat; may contain } \\
\text { perched water. }\end{array}$ \\
\hline
\end{tabular}

Source: Adapted from BN (2002) 
Appendix B

Summary Description of GoldSim ${ }^{\circledR}$ Software 


\section{B.1.0 GoldSim ${ }^{\circledast}$ Overview}

GoldSim $^{\circledR}$ is a general-purpose simulation software program designed to simulate complex systems in support of better decision making. GoldSim ${ }^{\circledR}$ is currently being used to support the investigation of radionuclide migration in groundwater as part of the UGTA Project. GoldSim ${ }^{\circledR}$ models constitute a major departure from the other models. Rather than simulating detailed processes at small scales and intergrating those impacts for larger scales, the GoldSim ${ }^{\circledR}$ approach uses one-dimensional transport simulations to simultaneously assess broad groupings of processes that influence the contaminant boundary. GoldSim ${ }^{\circledR}$ relies on the detailed process models developed for the source of contamination, groundwater flow, and contaminant transport to constrain the possible range of outcomes. The advantage of GoldSim ${ }^{\circledR}$ is speed of simulation and flexibility to incorporate almost any process. As a result, GoldSim ${ }^{B}$ is a convenient method to assess the full range of uncertainty inherent in the system without having to link and simulate numerous detailed process models.

GoldSim $^{\circledR}$,s key capabilities include the following:

- The variability and uncertainty present in real-world systems maybe quantitatively addressed using Monte Carlo simulations.

- The occurrence and consequences of discrete events may be superposed onto continuously varying systems.

- Top-down models may be constructed using hierarchical containers which facilitate the simulation of large and complex systems.

- External programs or spreadsheets may be directly and dynamically linked into GoldSim ${ }^{\circledR}$ models.

- Data may be directly exchanged between a GoldSim ${ }^{\circledR}$ model and any Open Database Connectivity (ODBC)-compliant database.

More information about the GoldSim ${ }^{\circledR}$ software may be found in the users guides (Golder, $2002 \mathrm{a}$ and b).

GoldSim $^{\circledR}$ has been used in the Yucca Mountain Project modeling activities. Its usage in the development of the YMP total system model is documented in a report titled: Total System Performance Assessment for the Site Recommendation (CRWMS M\&O, 2000). All YMP models are developed under their quality assurance program (DOE, 2000). 


\section{B.2.0 References}

CRWMS M\&O, see Civilian Radioactive Waste Management System Management and Operating Contractor.

Civilian Radioactive Waste Management System Management and Operating Contractor. 2000. Total System Performance Assessment for the Site Recommendation, TDR-WIS-PA-000001, Revision 00, ICN 01. Las Vegas, NV.

Golder. 2002a. Users Guide: GoldSim ${ }^{\circledR}$ Contaminant Transport Module, Version 1.30, (April).

Golder. 2002b. Users Guide: GoldSim ${ }^{\circledR}$ Graphical Simulation Environment, Version 7.40, (April).

U.S. Department of Energy. 2000. Quality Assurance Requirements and Description, DOE/RW-0333P, Rev. 10. Washington, DC: U.S. Department of Energy, Office of Civilian Radioactive Waste Management. ACC:MOL.20000427.0422. 
Appendix C Description of GeoChem Database 


\section{C.1.0 Description of GeoChem Database}

The GeoChem02 database was compiled for chemical analyses of water within the NTS and the surrounding region. The GeoChem database has been developed as part of the UGTA Project with the cooperation of several agencies actively participating in ongoing evaluation and characterization activities under contract to the DOE. The database has been constructed to provide up-to-date, comprehensive, and quality-controlled data in a uniform format for the support of current and future projects. The GeoChem database is updated on a semi-annual basis.

The area covered by the GeoChem database extends from approximately 35.6 to $39.7^{\circ}$ north latitude and from 114.1 to $117.6^{\circ}$ west longitude. Types of sampling sites include precipitation stations, surface water, springs, and wells. Data types include major ions, organic compounds, trace elements, radionuclides, and environmental isotopes. Analyses from over 5,000 samples, collected since 1901 from approximately 1,300 springs and wells, are included in the database.

The majority of the data originate from the USGS, DRI, U.S. Environmental Protection Agency (EPA), LLNL, Reynolds Electrical \& Engineering Co., Inc., and the Harry Reid Center for Environmental Studies (HRCES). Other data sources include published literature and a variety of programs and projects in support of the NNSA/NSO programs. These include the Hydrologic Resources Management Program, the LTHMP, NNSA/NSO's Annual Environmental Monitoring, and the UGTA.

The GeoChem database is documented in a user's guide (IT, 2002) which provides an explanation of the database configuration and summarizes the general content and utility of the individual data tables. The user's guide also provides a description of the quality assurance/quality control protocols for this database. The user's guide also includes full citations of the published data sources in the reference section.

\section{C.2.0 Reference}

IT Corporation. 2002. A User's Guide to the Comprehensive Chemistry Database for Groundwater at the Nevada Test Site, Rev. 4, ITLV/13052-070. Las Vegas, NV. 
Appendix D

Comparison of Mass Fluxes from the SSM and Particle Model (Process Model) for 37 Radionuclides in the CHESHIRE Inventory 


\section{D.1.0 Comparisons of Mass Flux from the SSM with the Process (Particle) Model for Tracer Radionuclides}

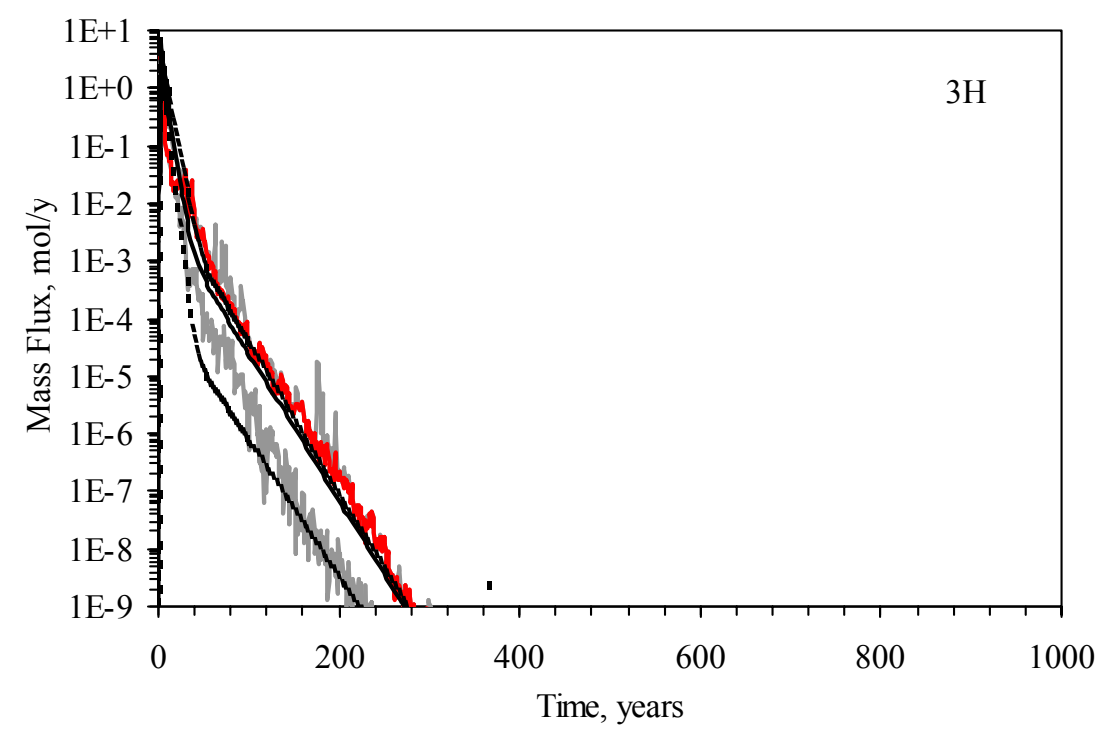

Figure D.1-1

Comparison of ${ }^{3} \mathrm{H}$ Exit Mass Fluxes from the Process Model with the SSM

Particle model results: mean (red), 5th and 95th percentiles (grey); SSM results: mean (solid black), maximum and minimum (dashed black) 


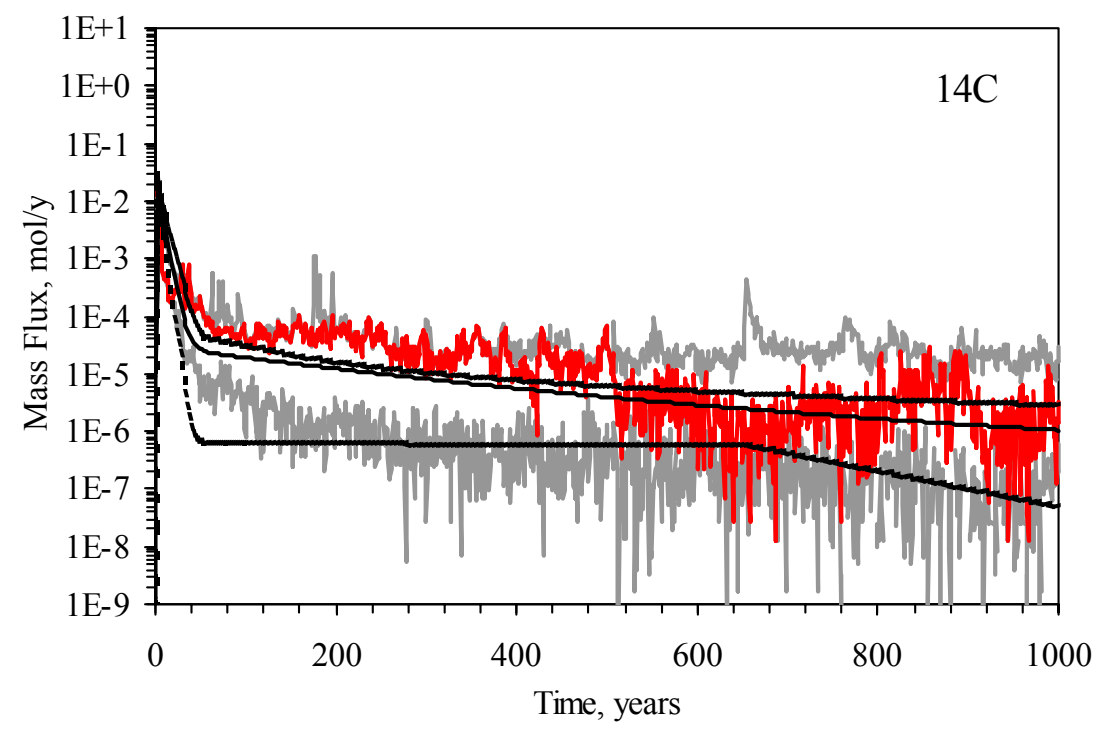

Figure D.1-2

Comparison of ${ }^{14} \mathrm{C}$ Exist Mass Fluxes from the Process Model with the SSM

Particle model results: mean (red), 5th and 95th percentiles (grey); SSM results: mean (solid black), maximum and minimum (dashed black)

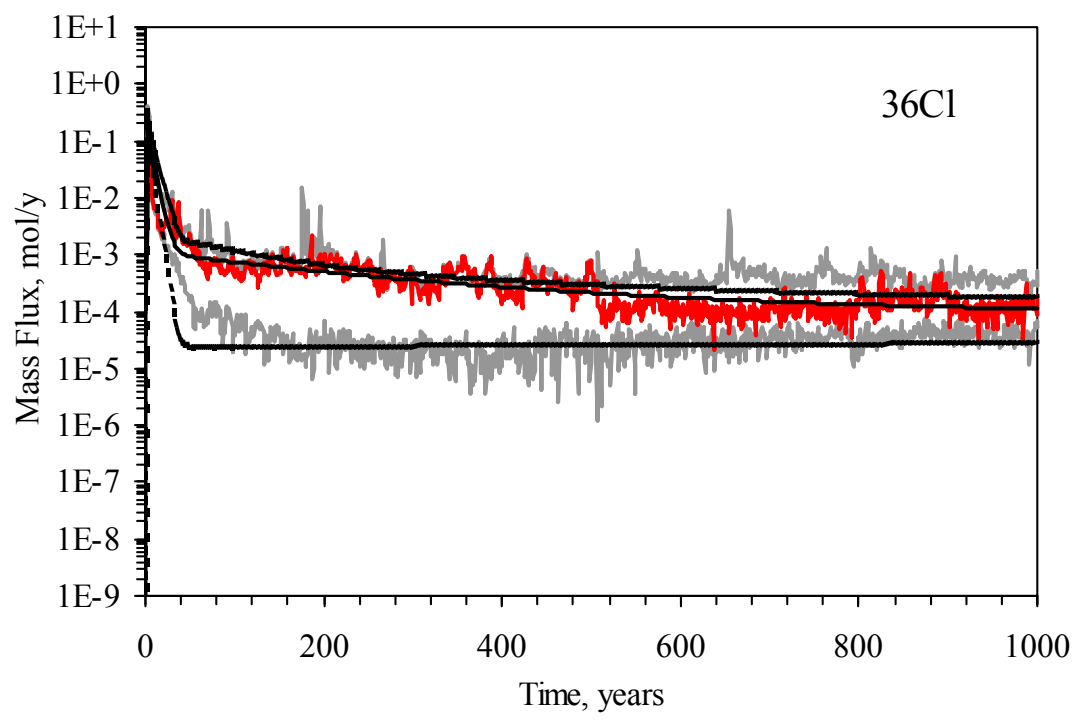

Figure D.1-3

Comparison of ${ }^{36} \mathrm{CI}$ Exist Mass Fluxes from the Process Model with the SSM

Particle model results: mean (red), 5th and 95th percentiles (grey); SSM results: mean (solid black), maximum and minimum (dashed black) 


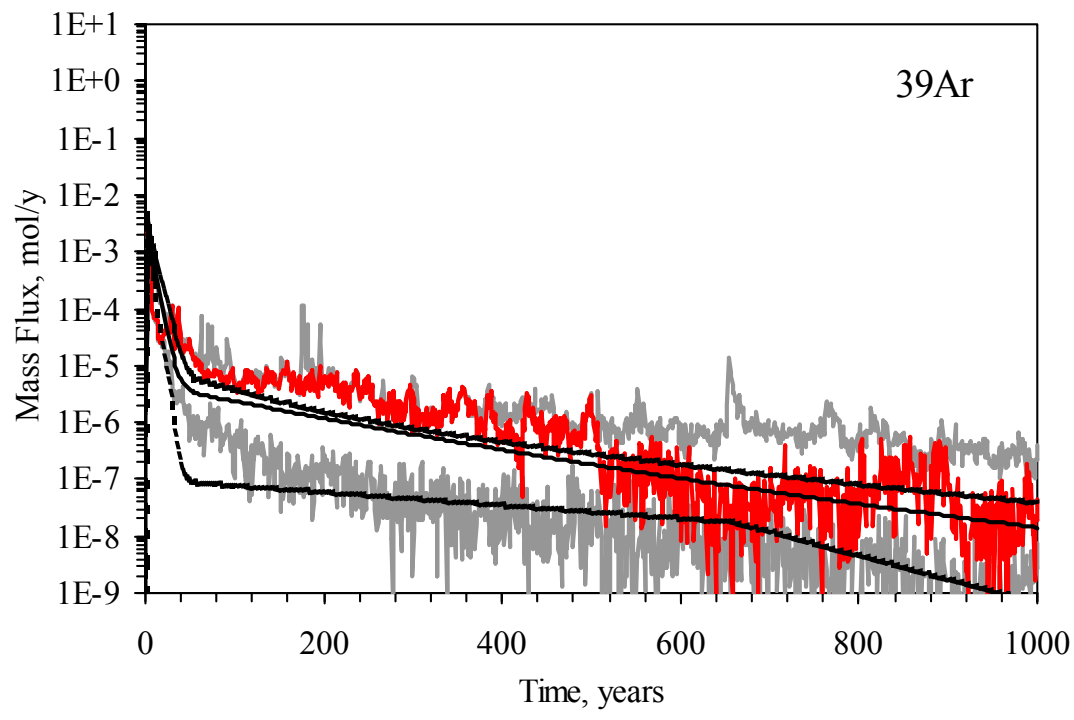

Figure D.1-4

Comparison of ${ }^{39} \mathrm{C}$ Ar Exit Mass Fluxes from the Process Model with the SSM

Particle model results: mean (red), 5th and 95th percentiles (grey); SSM results: mean (solid black), maximum and minimum (dashed black)

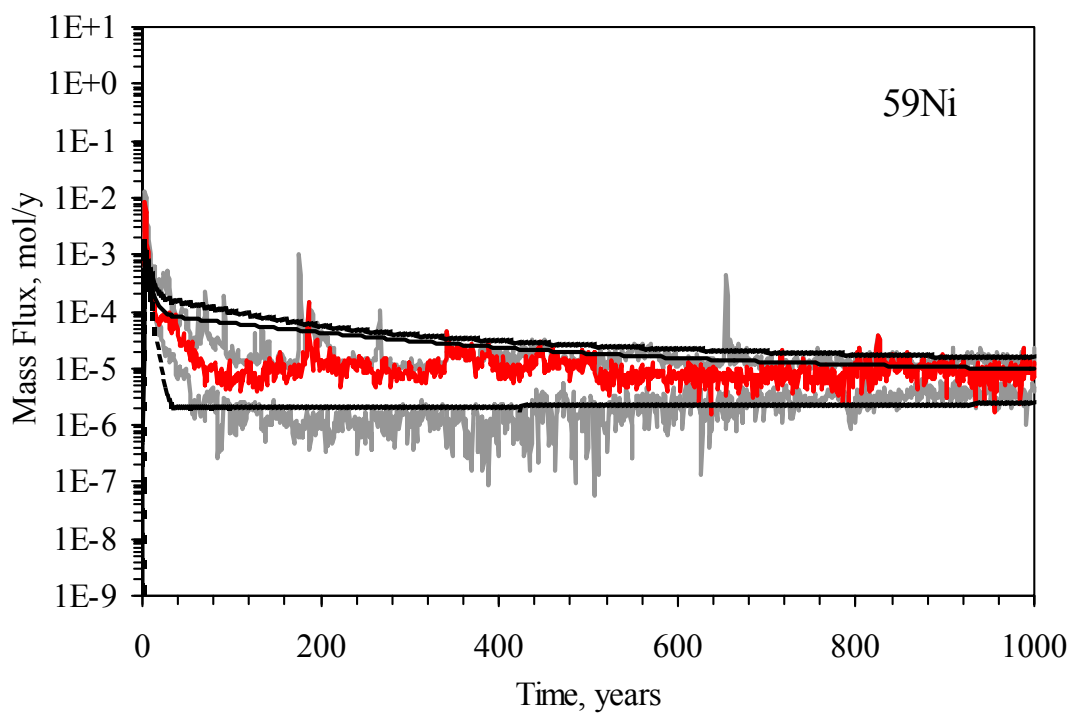

Figure D.1-5

Comparison of ${ }^{59} \mathrm{Ni}$ Exit Mass Fluxes from the Process Model with the SSM

Particle model results: mean (red), 5th and 95th percentiles (grey); SSM results: mean (solid black), maximum and minimum (dashed black) 


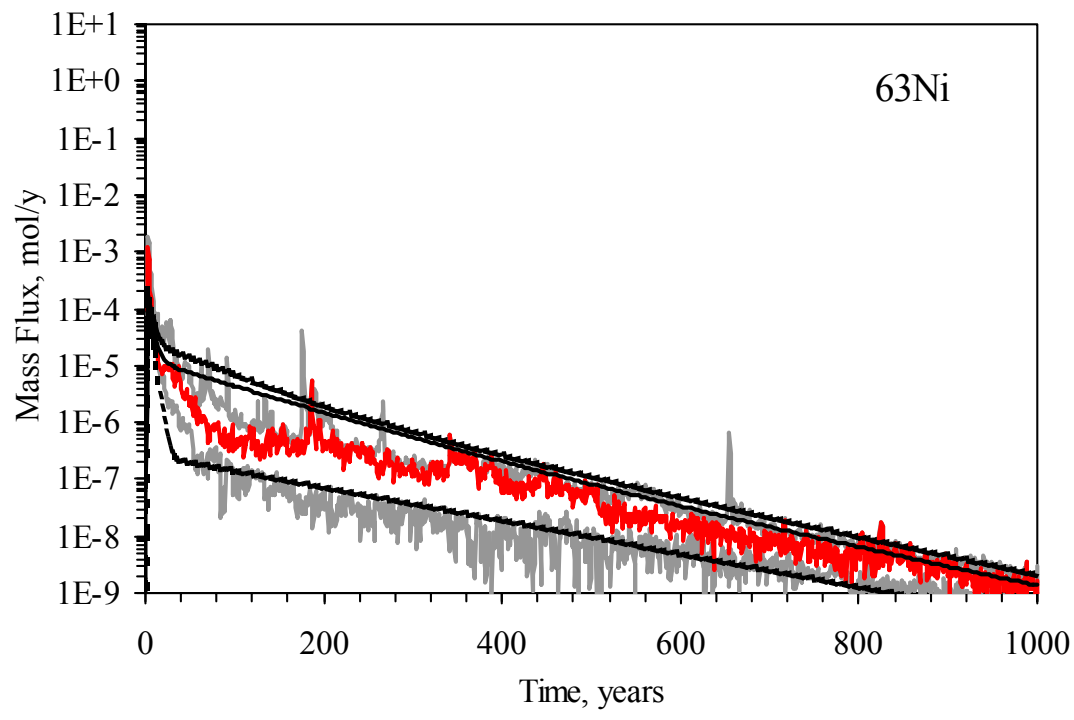

Figure D.1-6

Comparison of ${ }^{63} \mathrm{Ni}$ Exit Mass Fluxes from the Process Model with the SSM

Particle model results: mean (red), 5th and 95th percentiles (grey); SSM results: mean (solid black), maximum and minimum (dashed black)

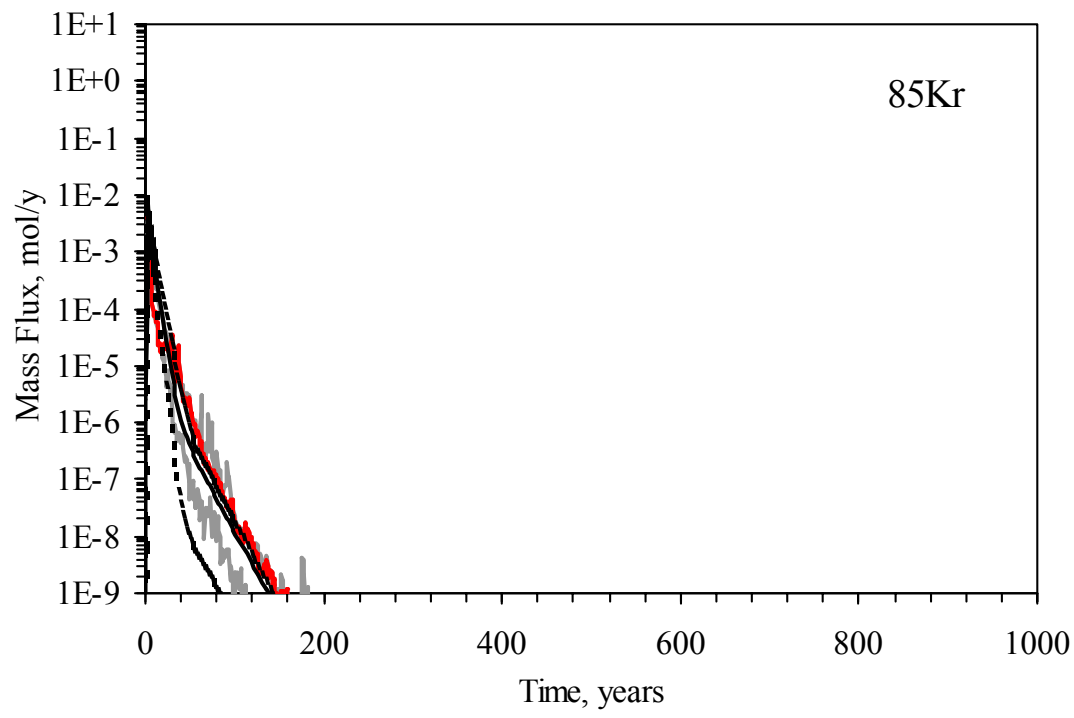

Figure D.1-7

Comparison of ${ }^{85} \mathrm{Kr}$ Exit Mass Fluxes from the Process Model with the SSM

Particle model results: mean (red), 5th and 95th percentiles (grey); SSM results: mean (solid black), maximum and minimum (dashed black) 


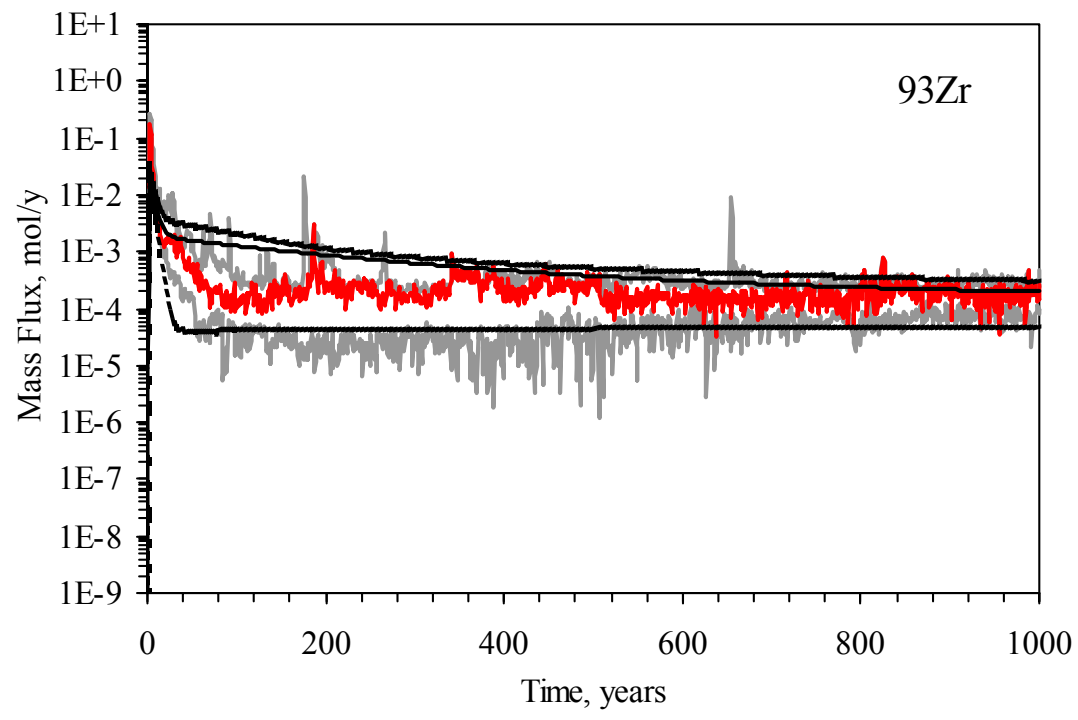

Figure D.1-8

Comparison of ${ }^{93} \mathrm{Zr}$ Exit Mass Fluxes from the Process Model with the SSM

Particle model results: mean (red), 5th and 95th percentiles (grey); SSM results: mean (solid black), maximum and minimum (dashed black)

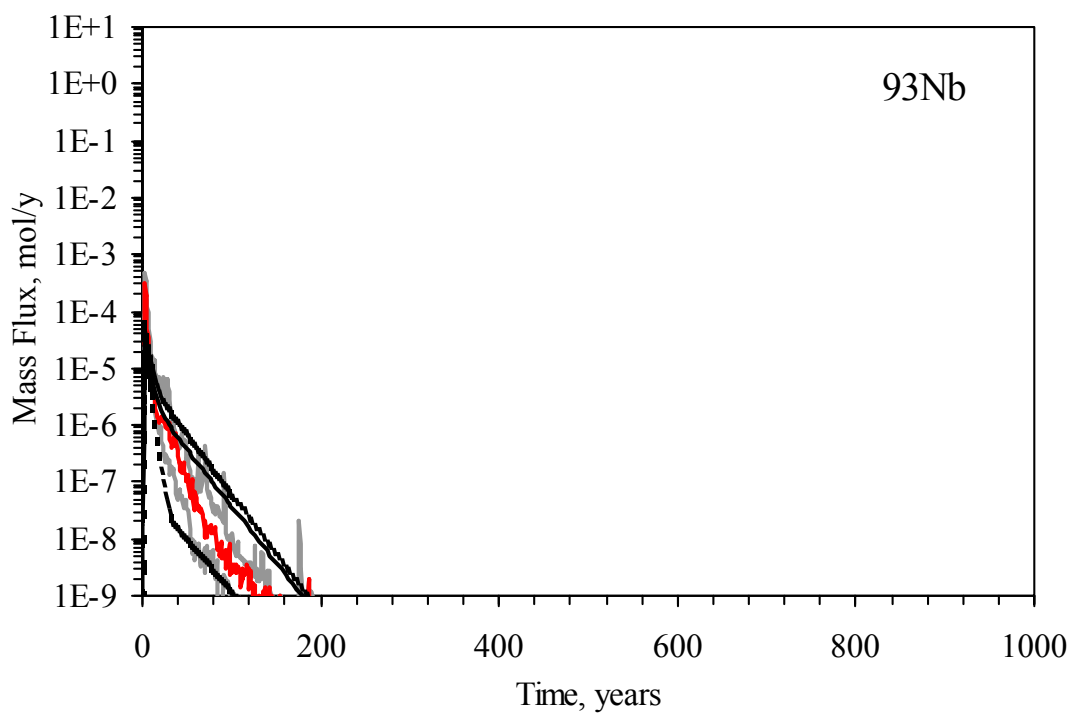

Figure D.1-9

Comparison of ${ }^{93} \mathrm{Nb}$ Exit Mass Fluxes from the Process Model with the SSM

Particle model results: mean (red), 5th and 95th percentiles (grey); SSM results: mean (solid black), maximum and minimum (dashed black) 


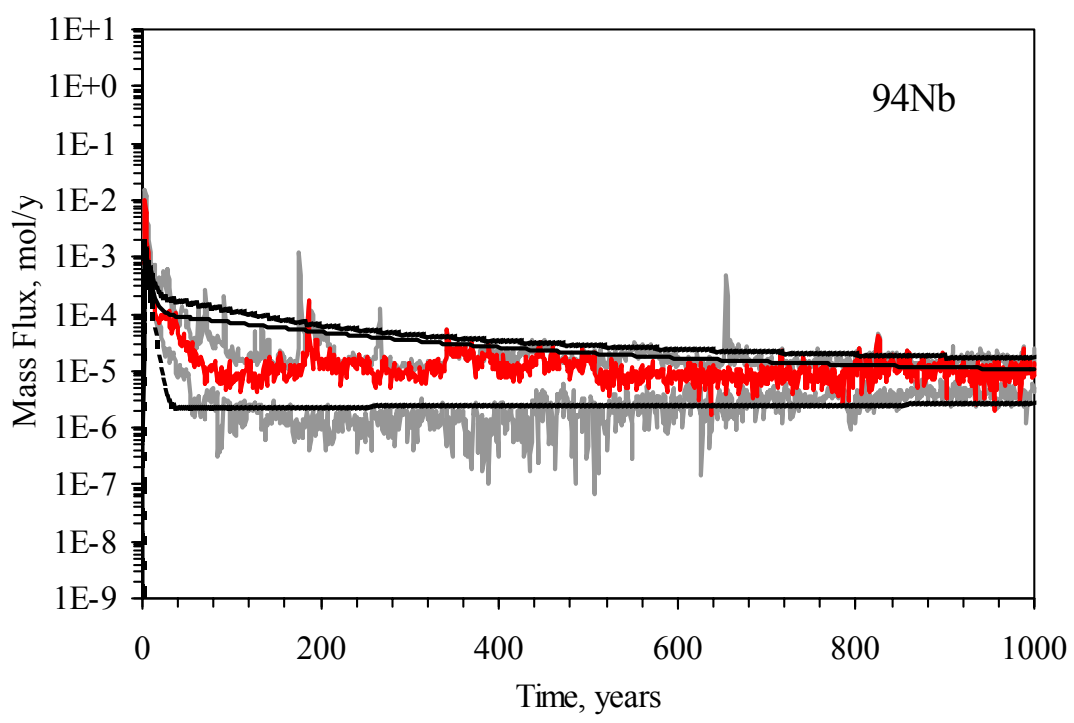

Figure D.1-10

Comparison of ${ }^{94} \mathrm{Nb}$ Exit Mass Fluxes from the Process Model with the SSM

Particle model results: mean (red), 5th and 95th percentiles (grey); SSM results: mean (solid black), maximum and minimum (dashed black)

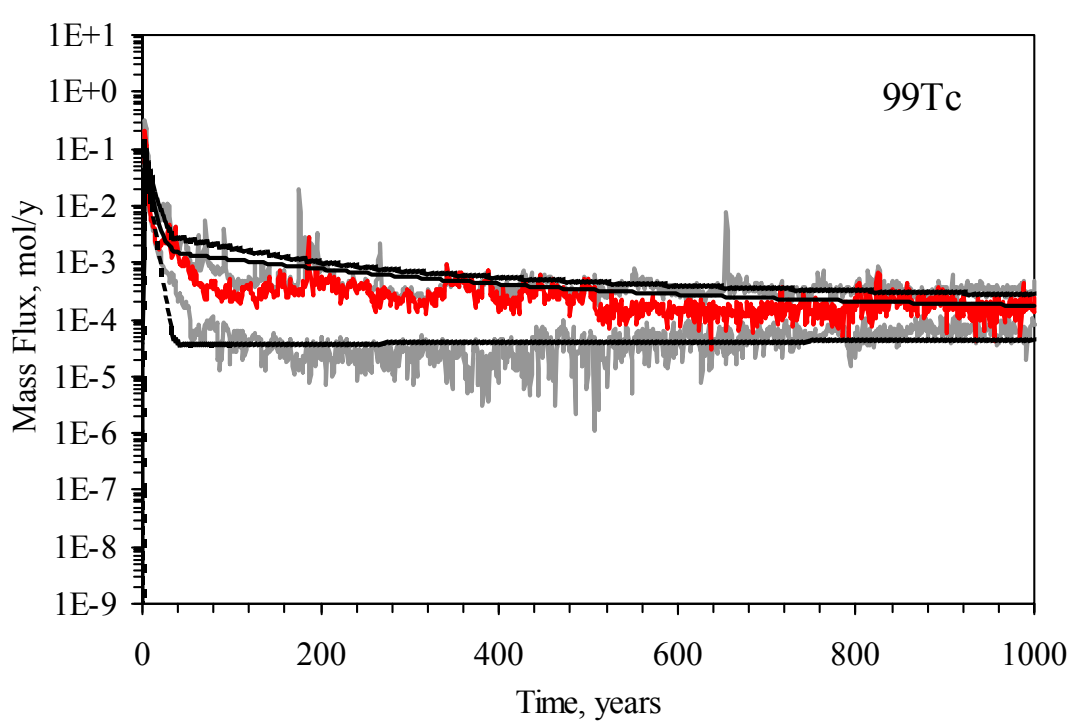

Figure D.1-11

Comparison of ${ }^{99} \mathrm{Tc}$ Exit Mass Fluxes from the Process Model with the SSM

Particle model results: mean (red), 5th and 95th percentiles (grey); SSM results: mean (solid black), maximum and minimum (dashed black) 


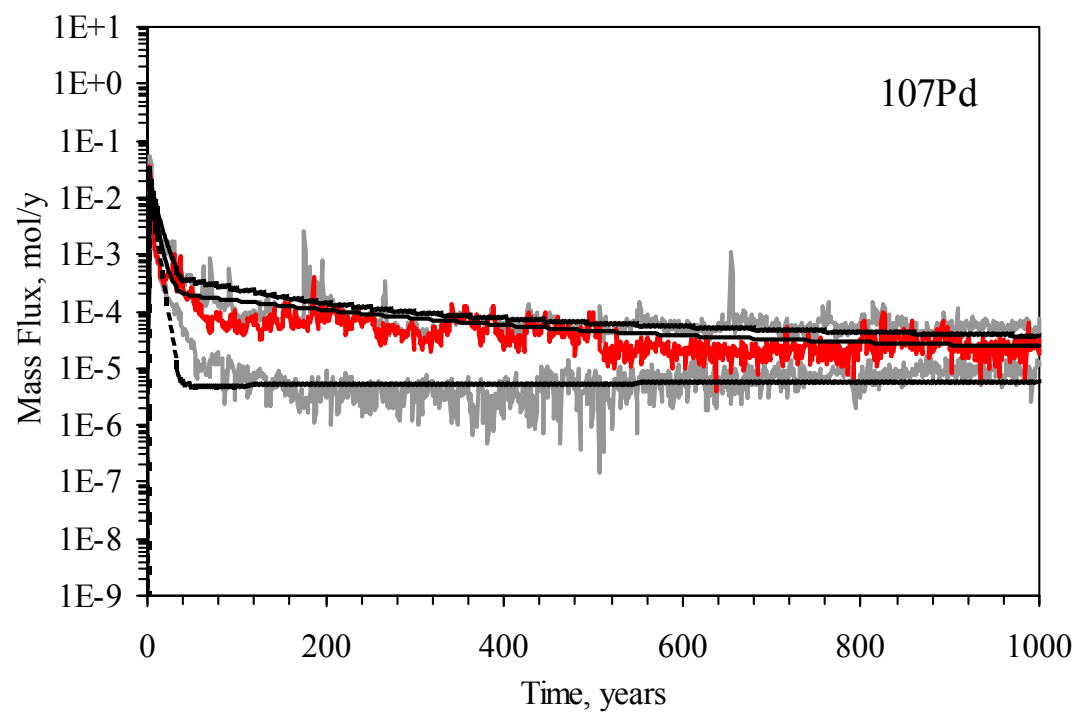

Figure D.1-12

Comparison of ${ }^{107} \mathrm{Pd}$ Exit Mass Fluxes from the Process Model with the SSM

Particle model results: mean (red), 5th and 95th percentiles (grey); SSM results: mean (solid black), maximum and minimum (dashed black)

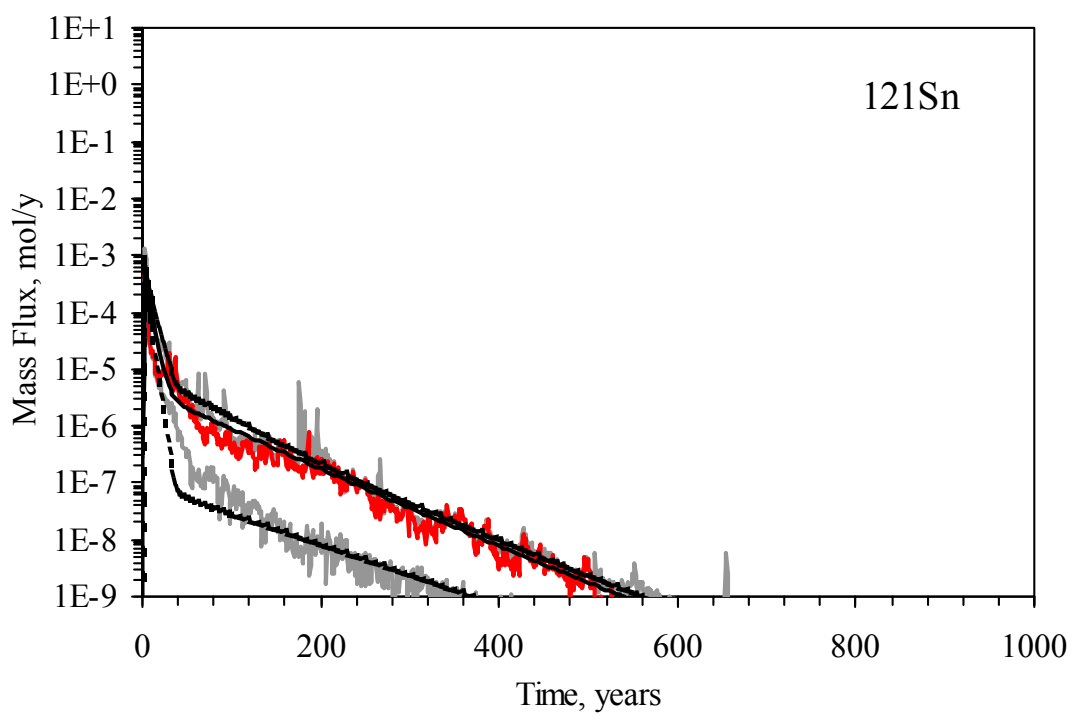

Figure D.1-13

Comparison of ${ }^{121}$ Sn Exit Mass Fluxes from the Process Model with the SSM

Particle model results: mean (red), 5th and 95th percentiles (grey); SSM results: mean (solid black), maximum and minimum (dashed black) 


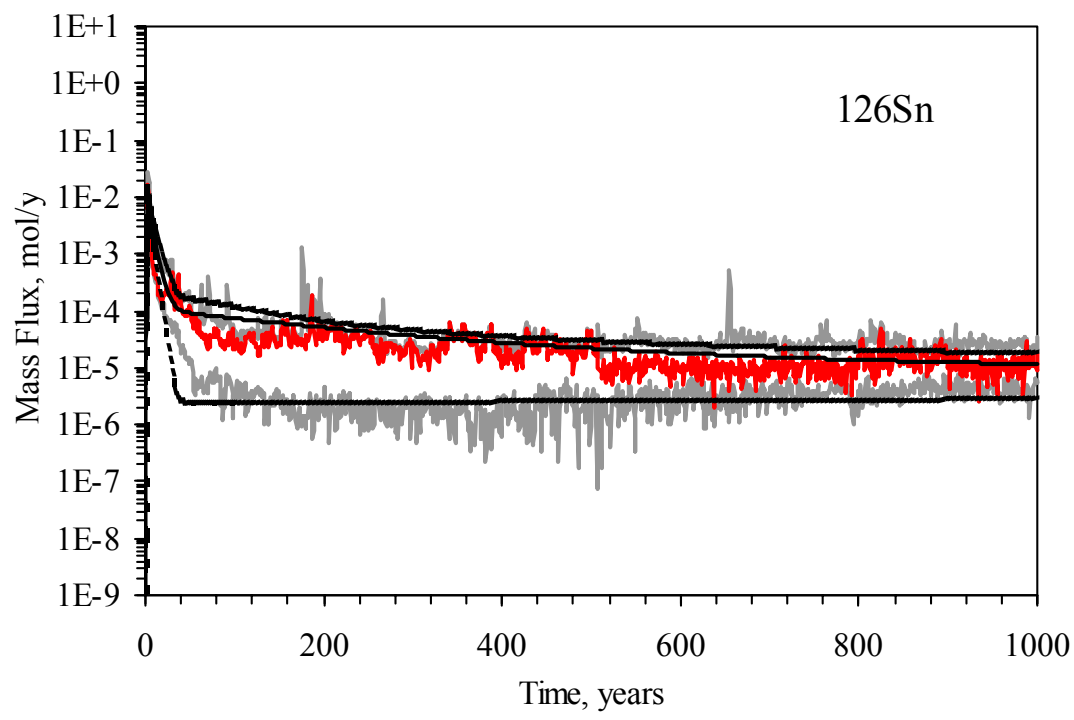

Figure D.1-14

Comparison of ${ }^{126}$ Sn Exit Mass Fluxes from the Process Model with the SSM

Particle model results: mean (red), 5th and 95th percentiles (grey); SSM results: mean (solid black), maximum and minimum (dashed black)

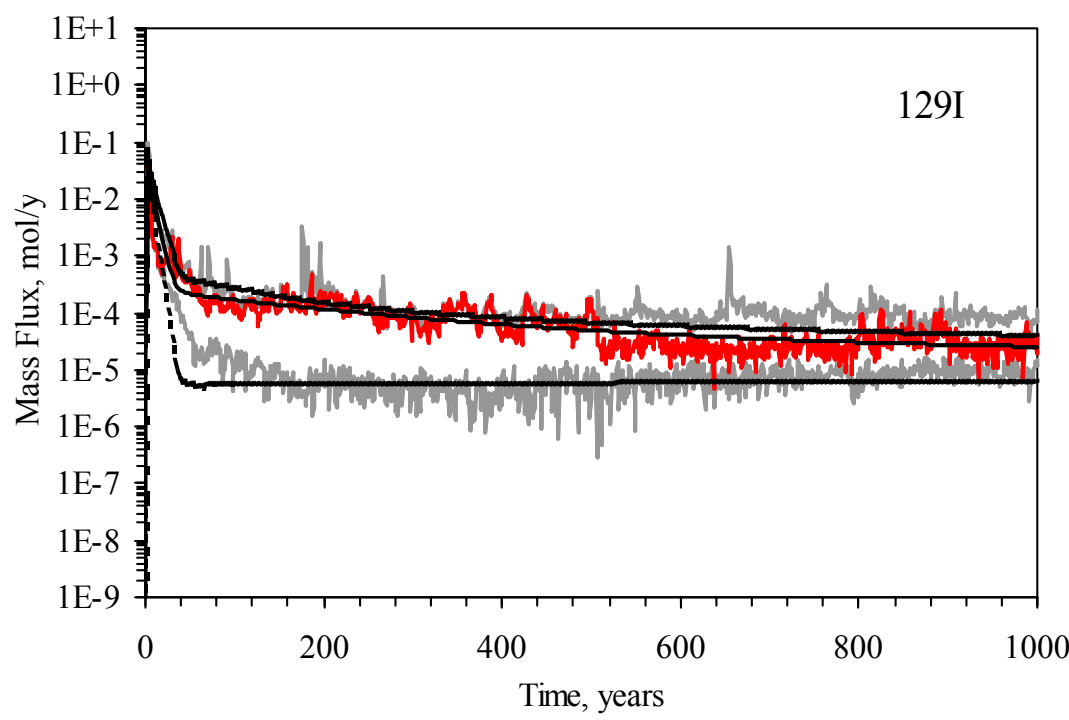

Figure D.1-15

Comparison of ${ }^{129}$ I Exit Mass Fluxes from the Process Model with the SSM

Particle model results: mean (red), 5th and 95th percentiles (grey;) SSM results: mean (solid black), maximum and minimum (dashed black) 


\section{D.2.0 Comparisons of Mass Flux from the SSM with the Process (Particle) Model for Sorbing Radionuclides with a Fracture Spacing of 1.5 per Meter}

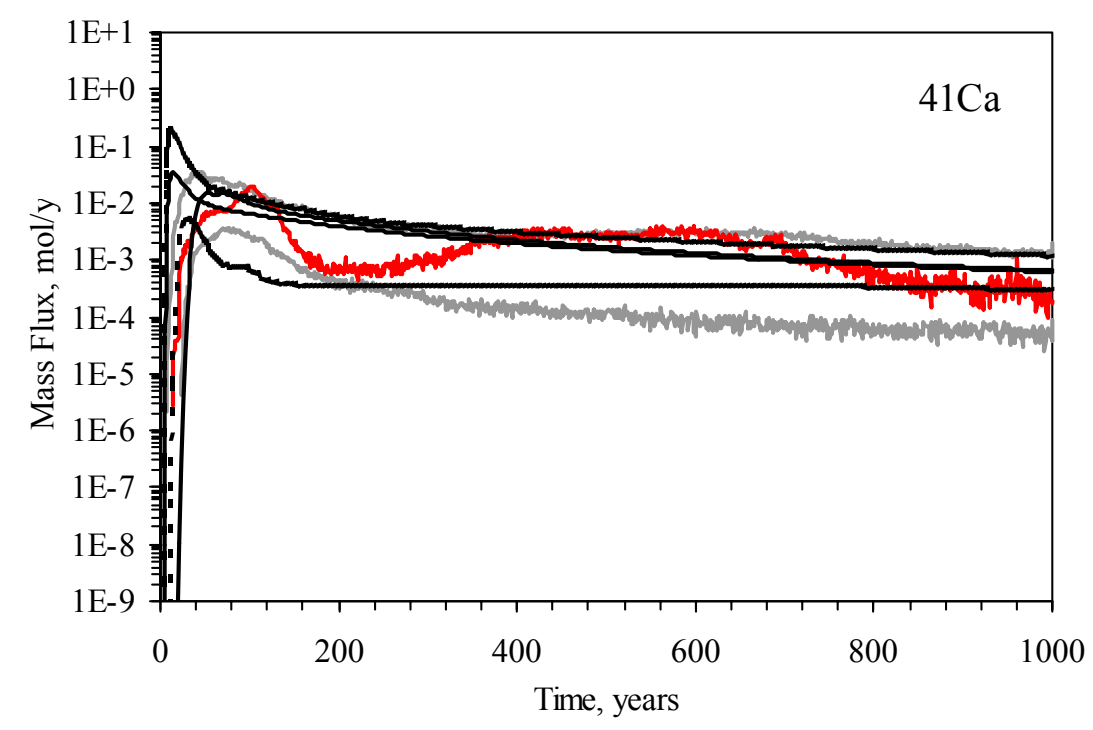

Figure D.2-1

Comparison of ${ }^{41} \mathrm{Ca}$ Exit Mass Fluxes from the Process Model with the SSM

Particle model results: mean (red), 5th and 95th percentiles (grey); SSM results: mean (solid black), maximum and minimum (dashed black) 


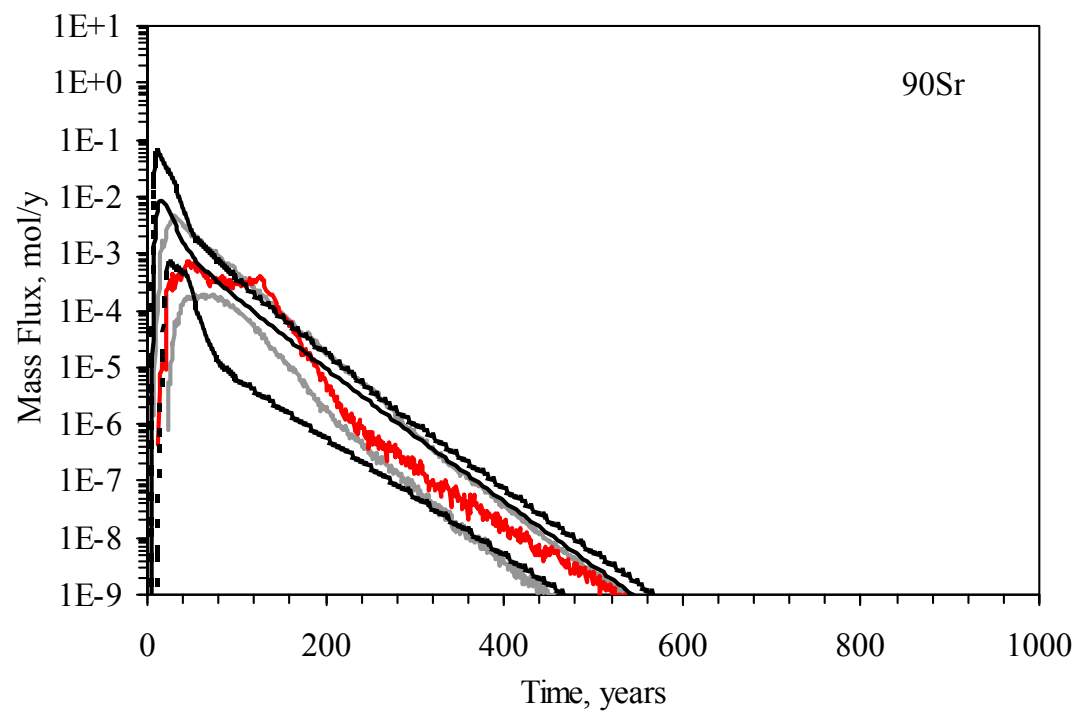

Comparison of ${ }^{90} \mathrm{Sr}$ Exit Mass Fluxes from the Process Model with the SSM

Particle model results: mean (red), 5th and 95th percentiles (grey); SSM results: mean (solid black), maximum and minimum (dashed black)

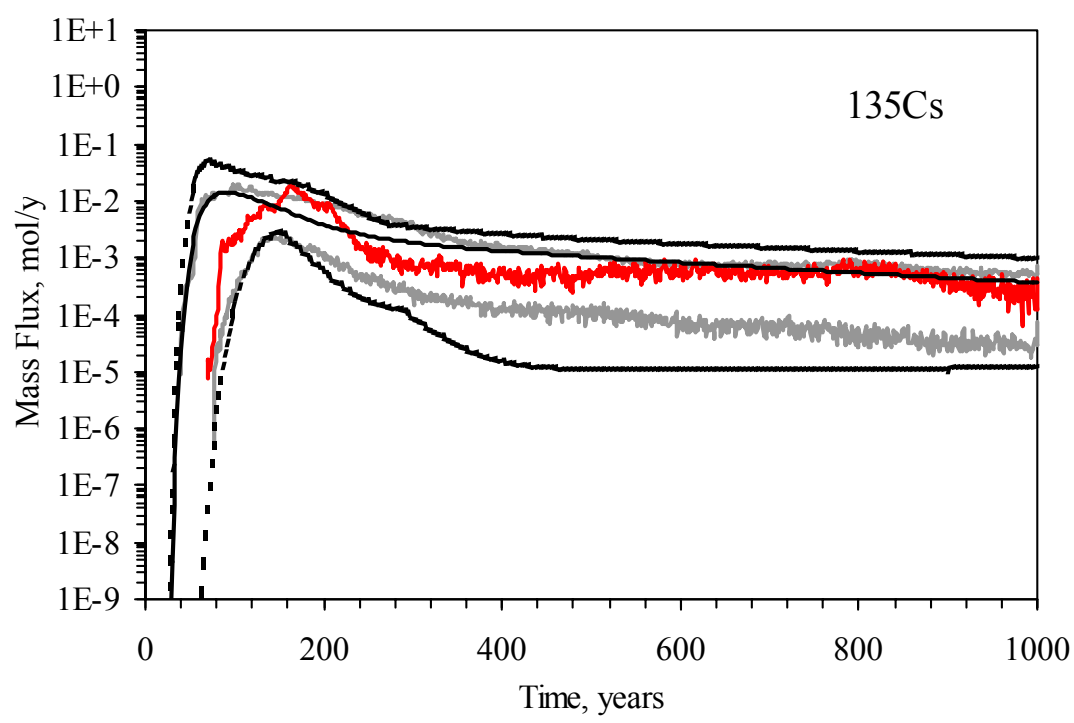

Figure D.2-3

Comparison of ${ }^{135}$ Cs Exit Mass Fluxes from the Process Model with the SSM

Particle model results: mean (red), 5th and 95th percentiles (grey); SSM results: mean (solid black), maximum and minimum (dashed black) 


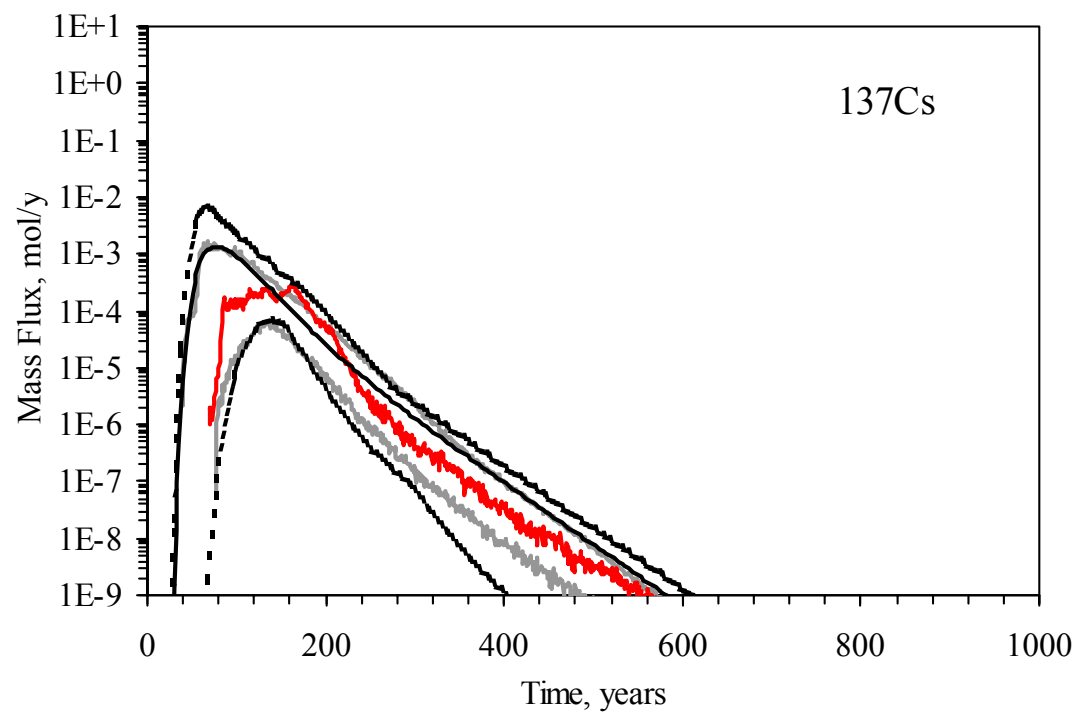

Figure D.2-4

Comparison of ${ }^{137}$ Cs Exit Mass Fluxes from the Process Model with the SSM

Particle model results: mean (red), 5th and 95th percentiles (grey); SSM results: mean (solid black), maximum and minimum (dashed black)

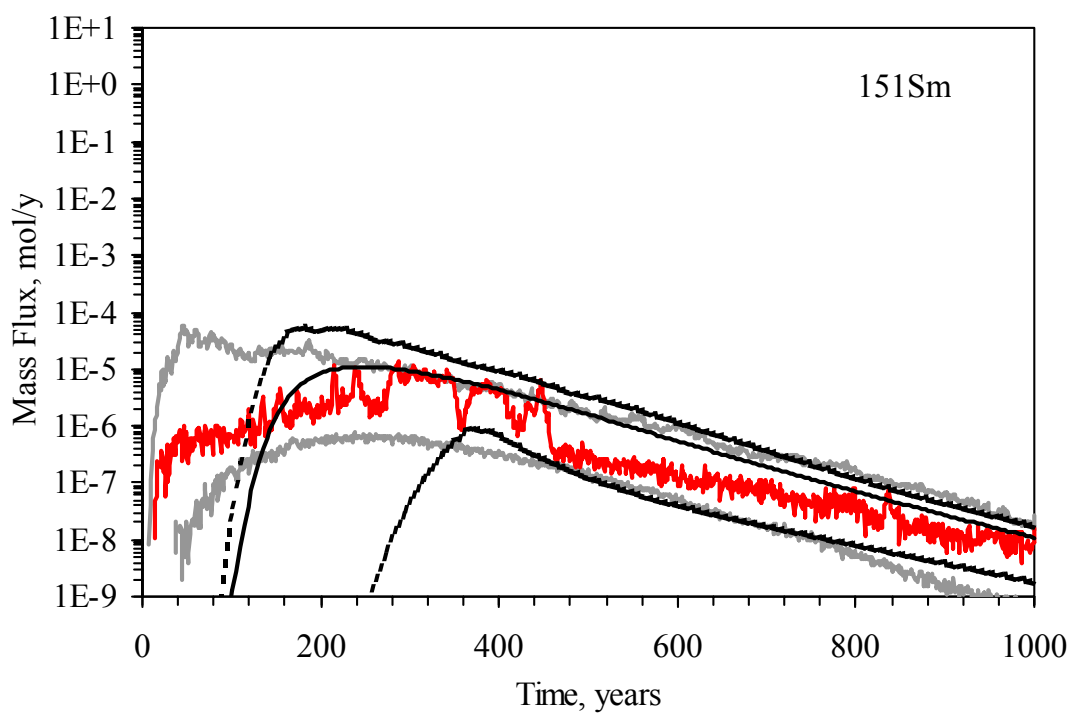

Figure D.2-5

Comparison of ${ }^{151} \mathrm{Sm}$ Exit Mass Fluxes from the Process Model with the SSM

Particle model results: mean (red), 5th and 95th percentiles (grey); SSM results: mean (solid black), maximum and minimum (dashed black) 


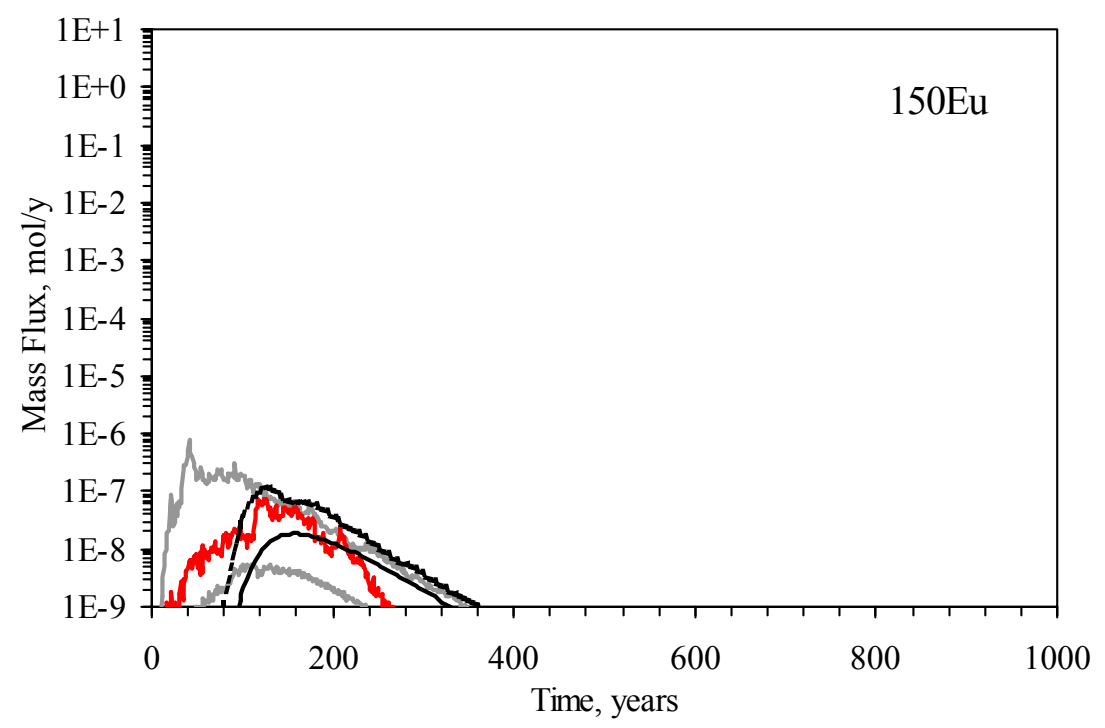

Figure D.2-6

Comparison of ${ }^{150}$ Eu Exit Mass Fluxes from the Process Model with the SSM

Particle model results: mean (red), 5th and 95th percentiles (grey); SSM results: mean (solid black), maximum and minimum (dashed black)

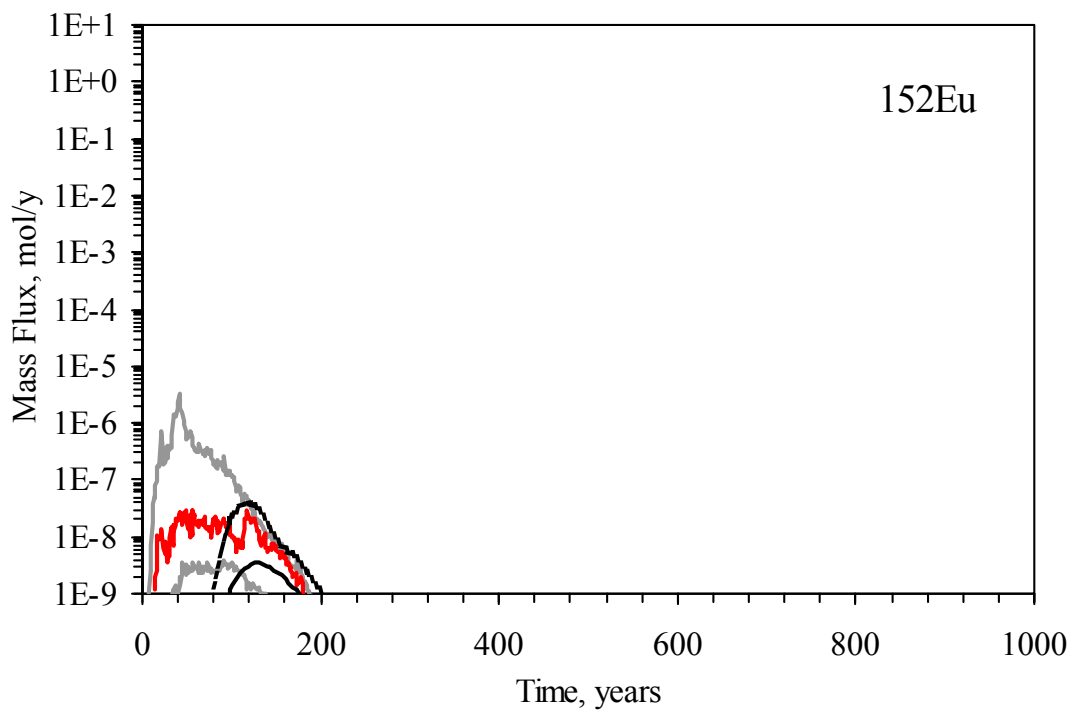

Figure D.2-7

Comparison of ${ }^{152}$ Eu Exit Mass Fluxes from the Process Model with the SSM

Particle model results: mean (red), 5th and 95th percentiles (grey); SSM results: mean (solid black), maximum and minimum (dashed black) 


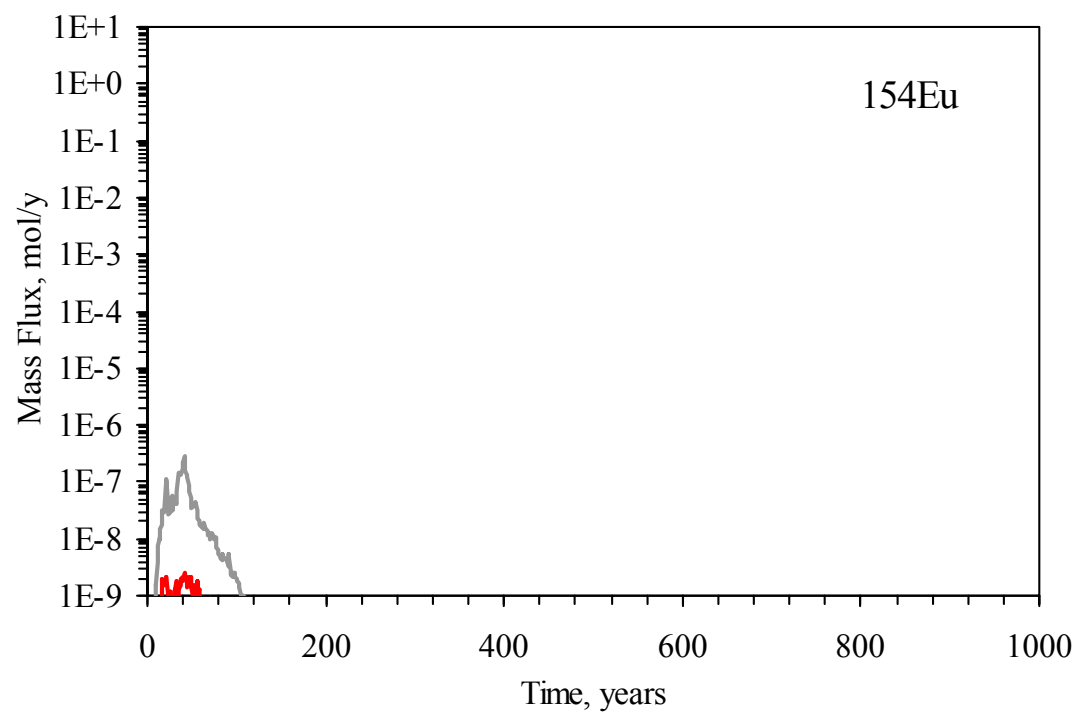

Figure D.2-8

Comparison of ${ }^{154}$ Eu Exit Mass Fluxes from the Process Model with the SSM

Particle model results: mean (red), 5th and 95th percentiles (grey); SSM results: mean (solid black), maximum and minimum (dashed black)

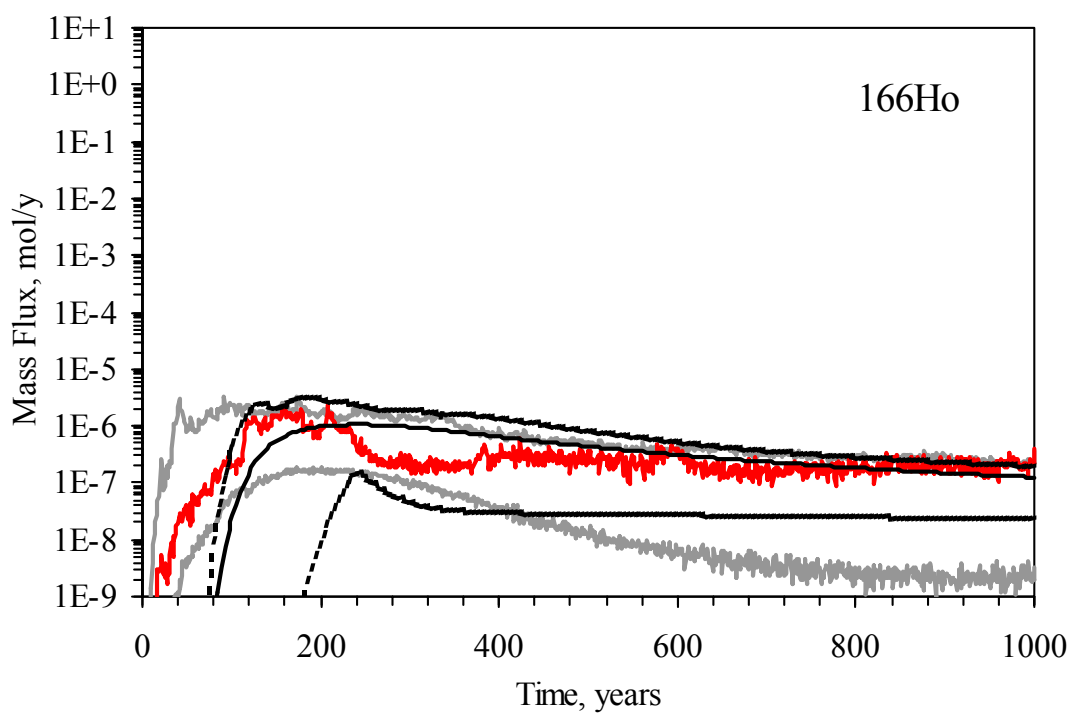

Figure D.2-9

Comparison of ${ }^{166}$ Ho Exit Mass Fluxes from the Process Model with the SSM

Particle model results: mean (red), 5th and 95th percentiles (grey); SSM results: mean (solid black), maximum and minimum (dashed black) 


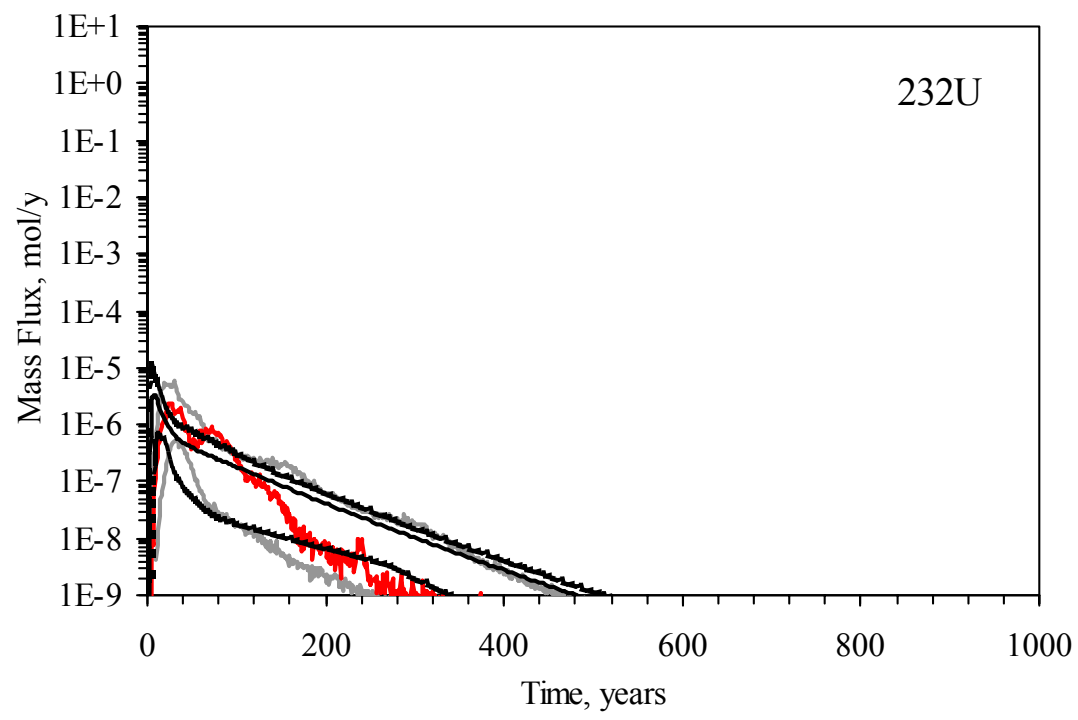

Figure D.2-10

Comparison of ${ }^{232} \mathrm{U}$ Exit Mass Fluxes from the Process Model with the SSM

Particle model results: mean (red), 5th and 95th percentiles (grey); SSM results: mean (solid black), maximum and minimum (dashed black)

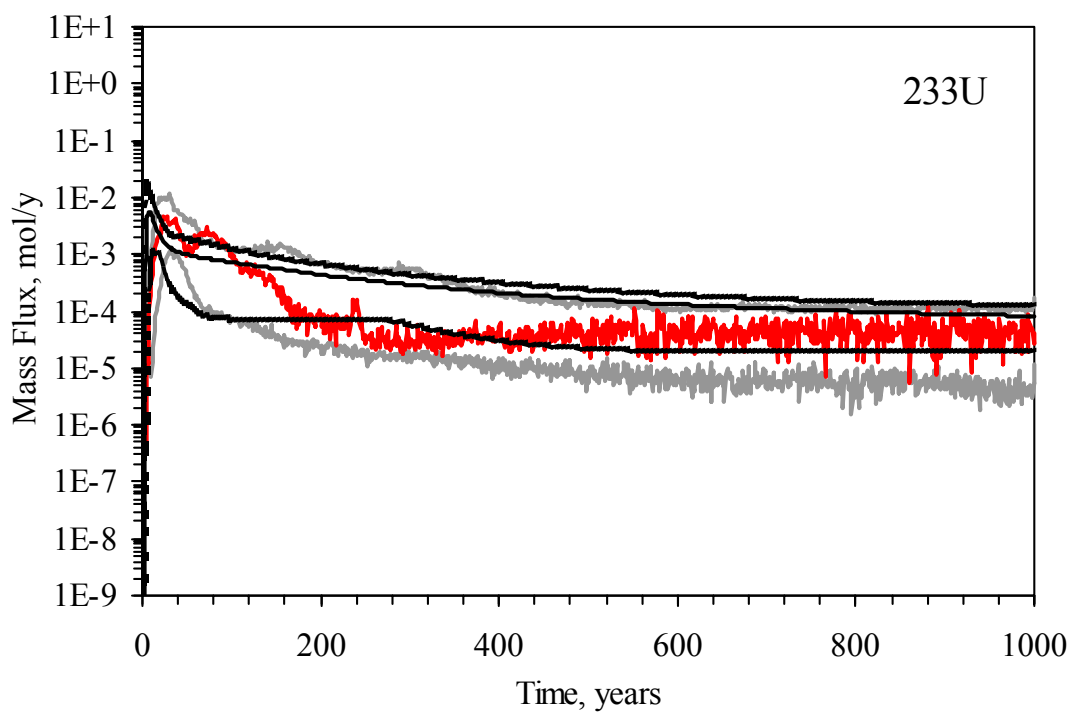

Figure D.2-11

Comparison of ${ }^{233} \mathrm{U}$ Exit Mass Fluxes from the Process Model with the SSM

Particle model results: mean (red), 5th and 95th percentiles (grey); SSM results: mean (solid black), maximum and minimum (dashed black) 


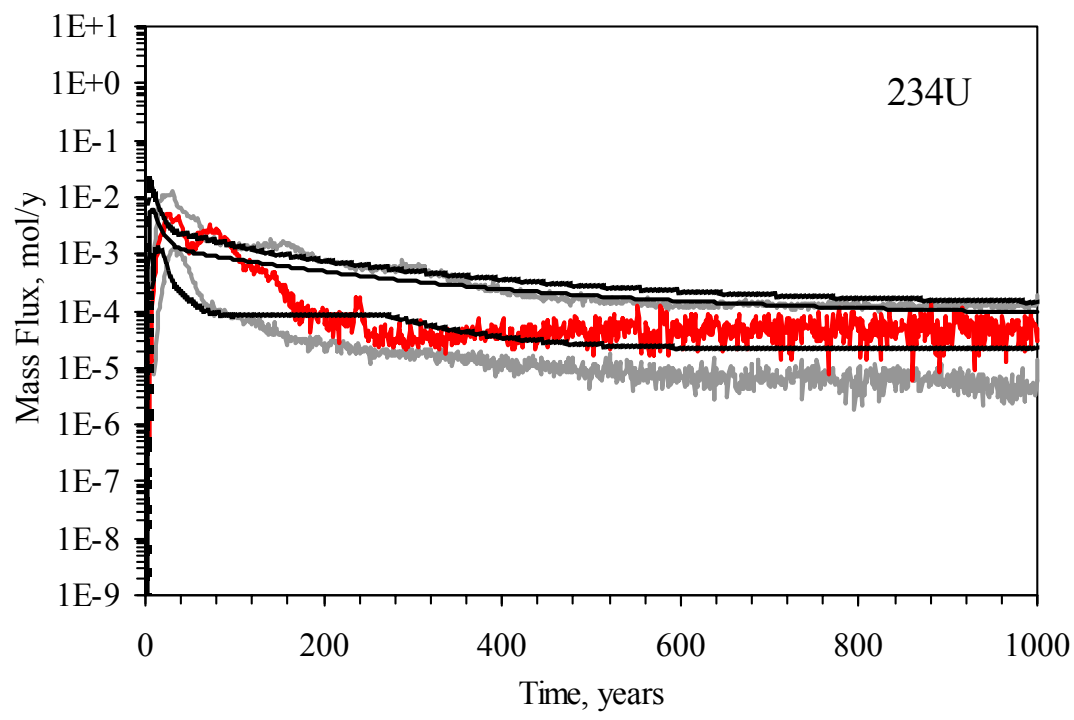

Figure D.2-12

Comparison of ${ }^{234} \mathrm{U}$ Exit Mass Fluxes from the Process Model with the SSM

Particle model results: mean (red), 5th and 95th percentiles (grey); SSM results: mean (solid black), maximum and minimum (dashed black)

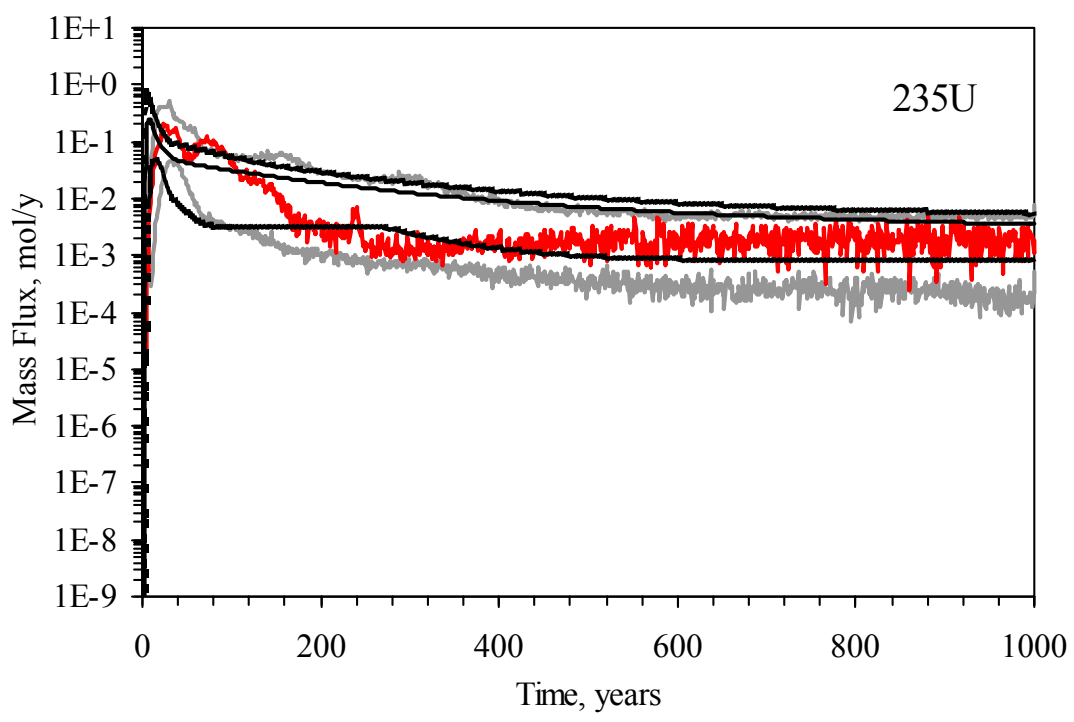

Figure D.2-13

Comparison of ${ }^{235} \mathrm{U}$ Exit Mass Fluxes from the Process Model with the SSM

Particle model results: mean (red), 5th and 95th percentiles (grey); SSM results: mean (solid black), maximum and minimum (dashed black) 


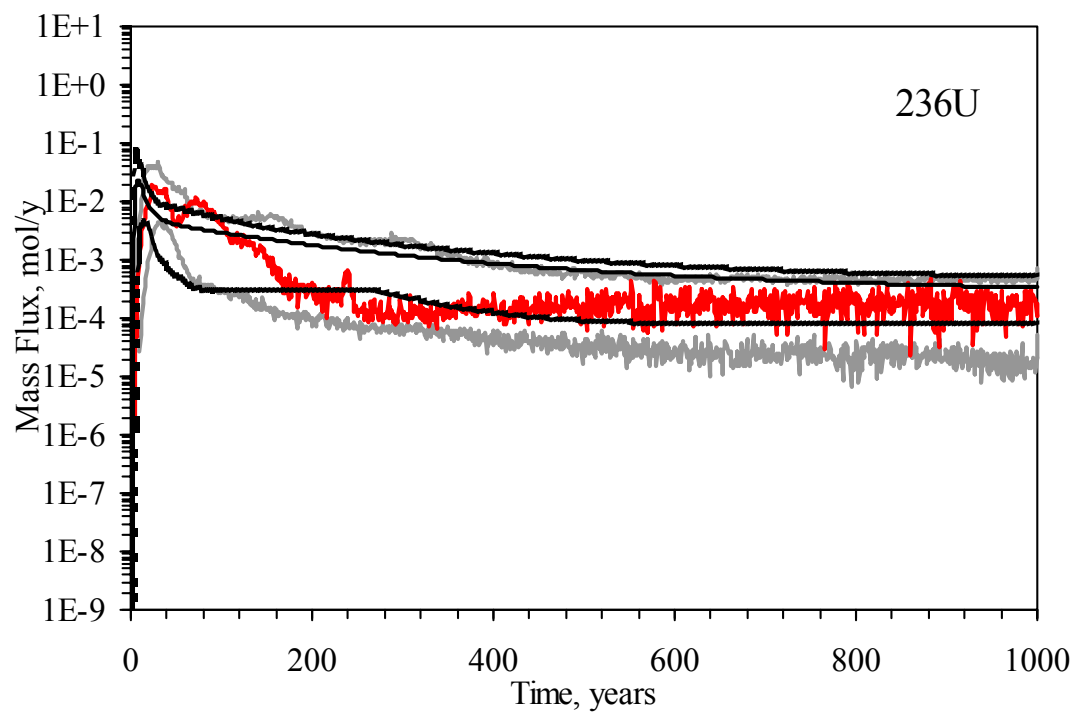

Figure D.2-14

Comparison of ${ }^{236} \mathrm{U}$ Exit Mass Fluxes from the Process Model with the SSM

Particle model results: mean (red), 5th and 95th percentiles (grey); SSM results: mean (solid black), maximum and minimum (dashed black)

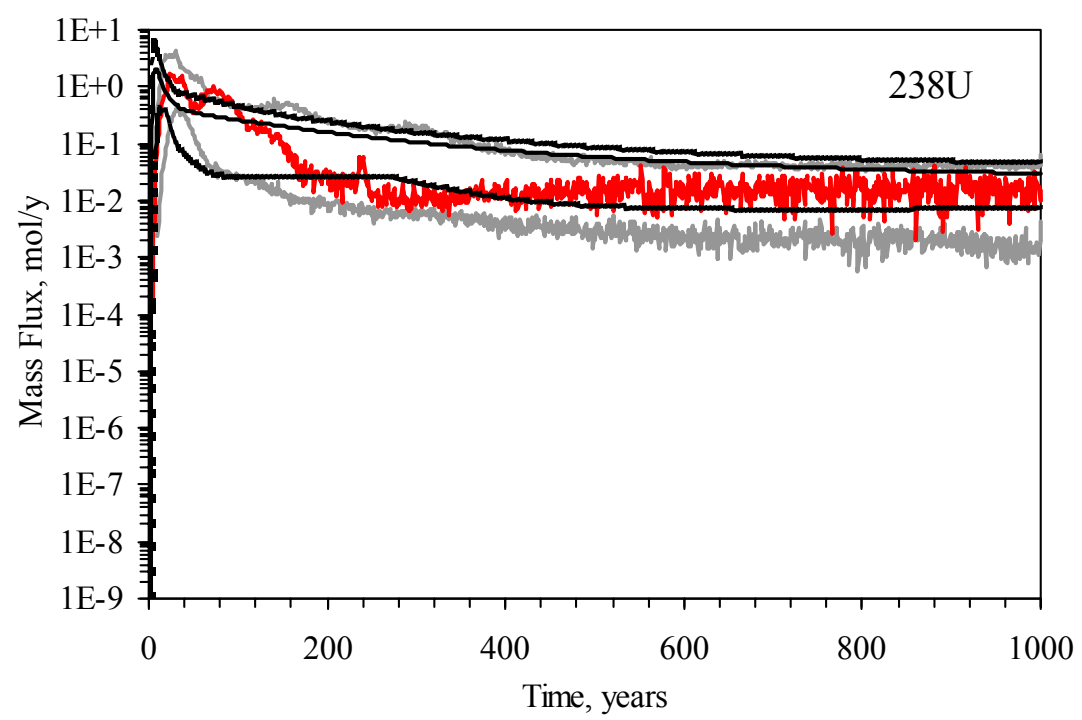

Figure D.2-15

Comparison of ${ }^{238} \mathrm{U}$ Exit Mass Fluxes from the Process Model with the SSM

Particle model results: mean (red), 5th and 95th percentiles (grey); SSM results: mean (solid black), maximum and minimum (dashed black) 


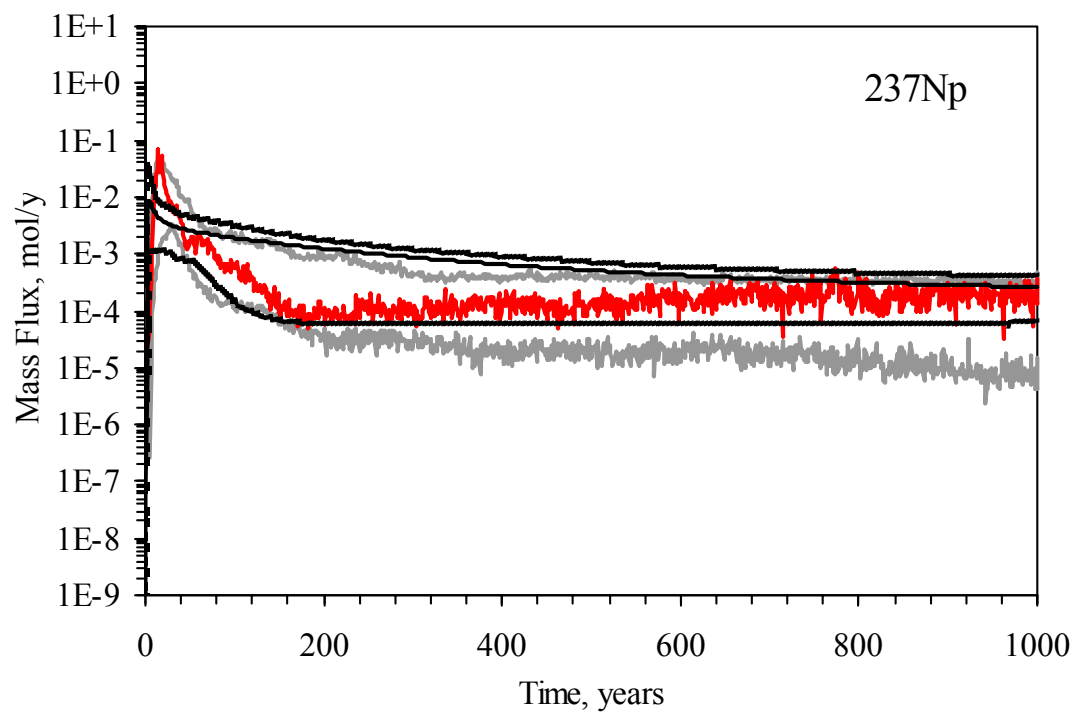

Figure D.2-16

Comparison of ${ }^{237} \mathrm{~Np}$ Exit Mass Fluxes from the Process Model with the SSM

Particle model results: mean (red), 5th and 95th percentiles (grey); SSM results: mean (solid black), maximum and minimum (dashed black)

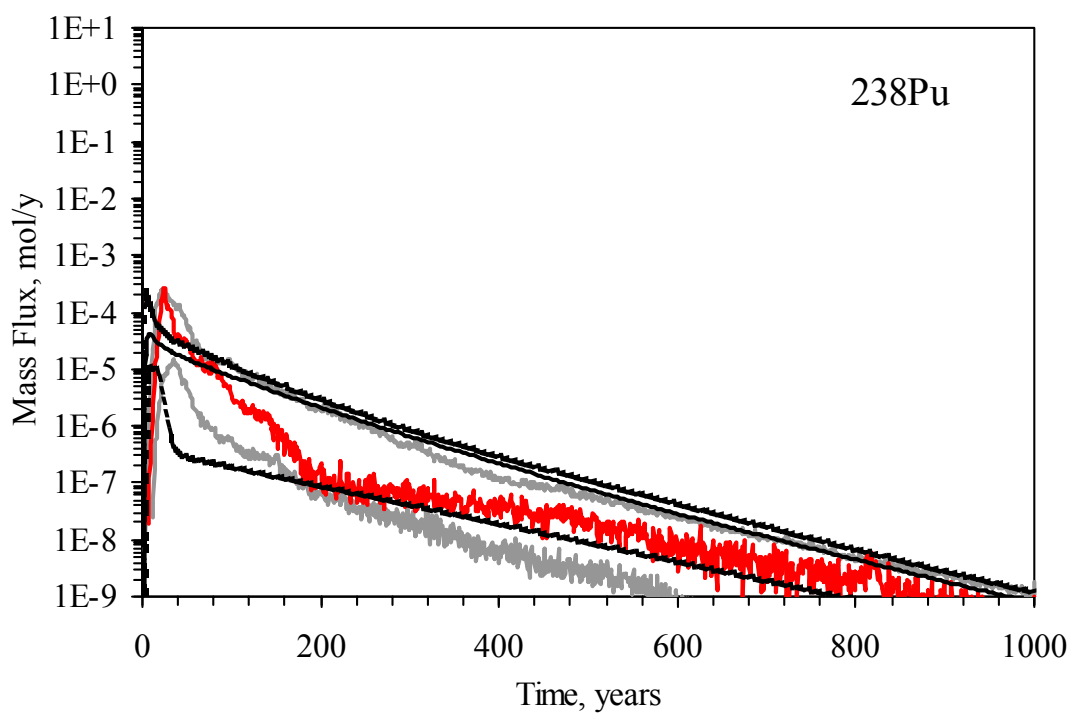

Figure D.2-17

Comparison of ${ }^{238} \mathrm{Pu}$ Exit Mass Fluxes from the Process Model with the SSM

Particle model results: mean (red), 5th and 95th percentiles (grey); SSM results: mean (solid black), maximum and minimum (dashed black) 


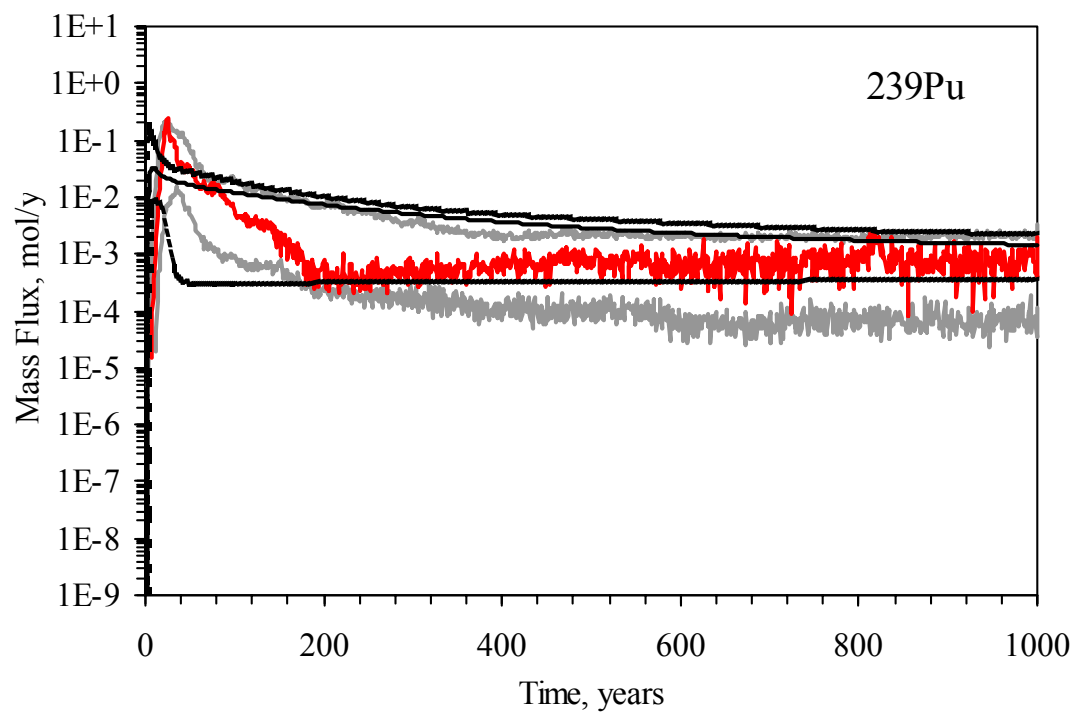

Figure D.2-18

Comparison of ${ }^{239} \mathrm{Pu}$ Exit Mass Fluxes from the Process Model with the SSM

Particle model results: mean (red), 5th and 95th percentiles (grey); SSM results: mean (solid black), maximum and minimum (dashed black)

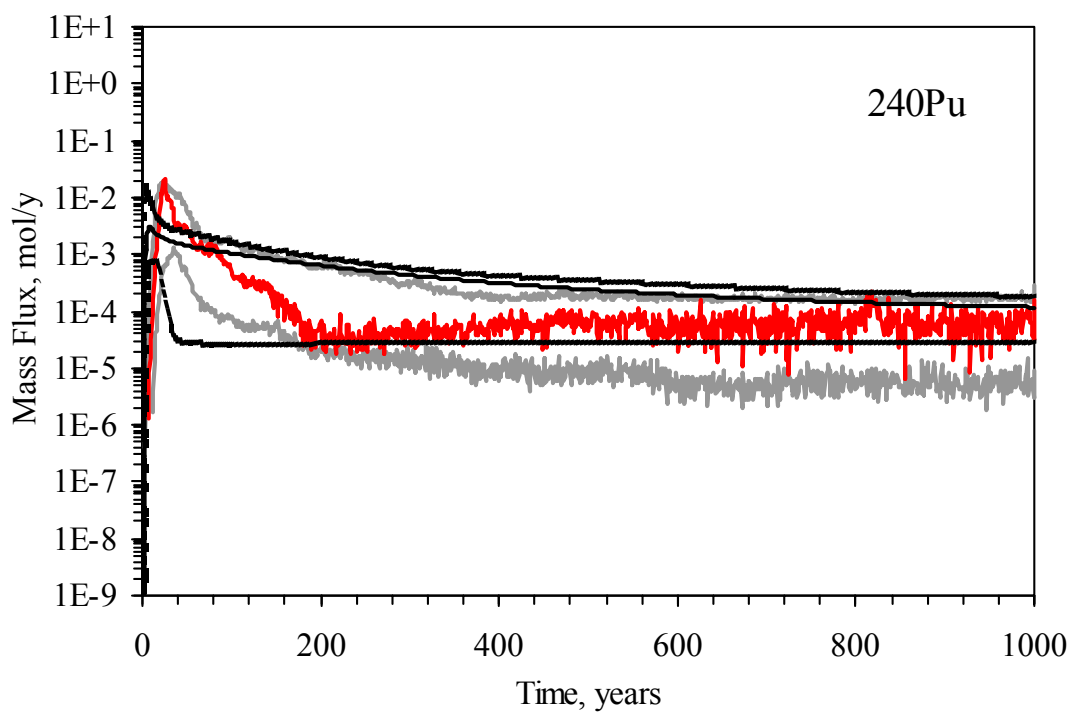

Figure D.2-19

Comparison of ${ }^{240} \mathrm{Pu}$ Exit Mass Fluxes from the Process Model with the SSM

Particle model results: mean (red), 5th and 95th percentiles (grey); SSM results: mean (solid black), maximum and minimum (dashed black) 


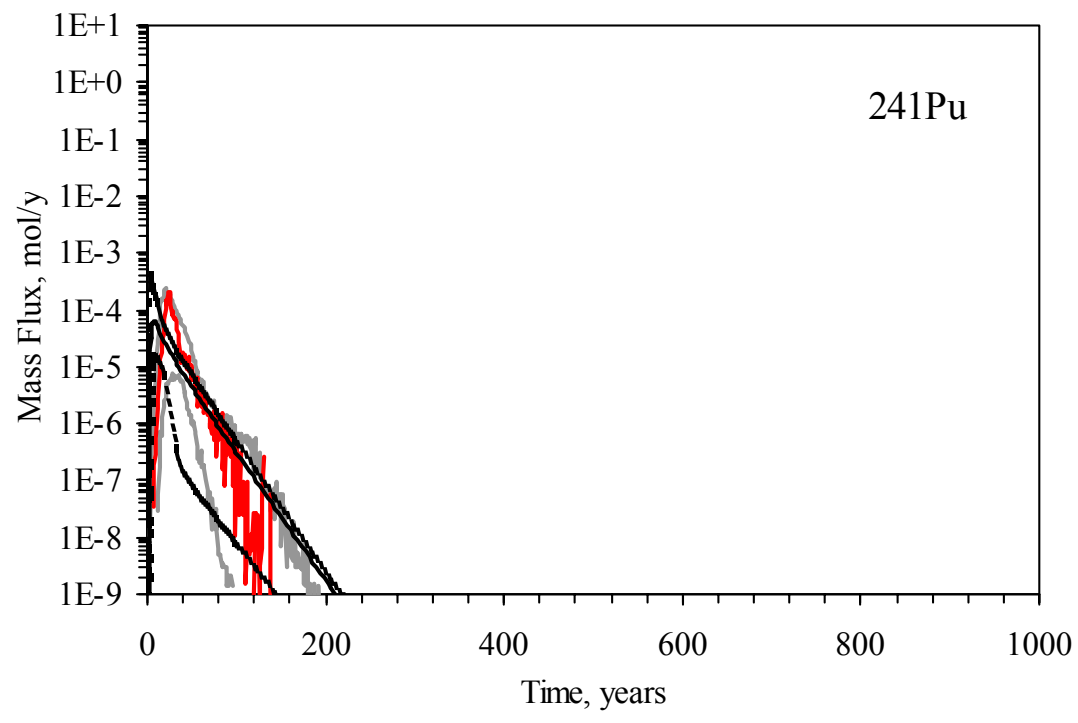

Figure D.2-20

Comparison of ${ }^{241} \mathrm{Pu}$ Exit Mass Fluxes from the Process Model with the SSM

Particle model results: mean (red), 5th and 95th percentiles (grey); SSM results: mean (solid black), maximum and minimum (dashed black)

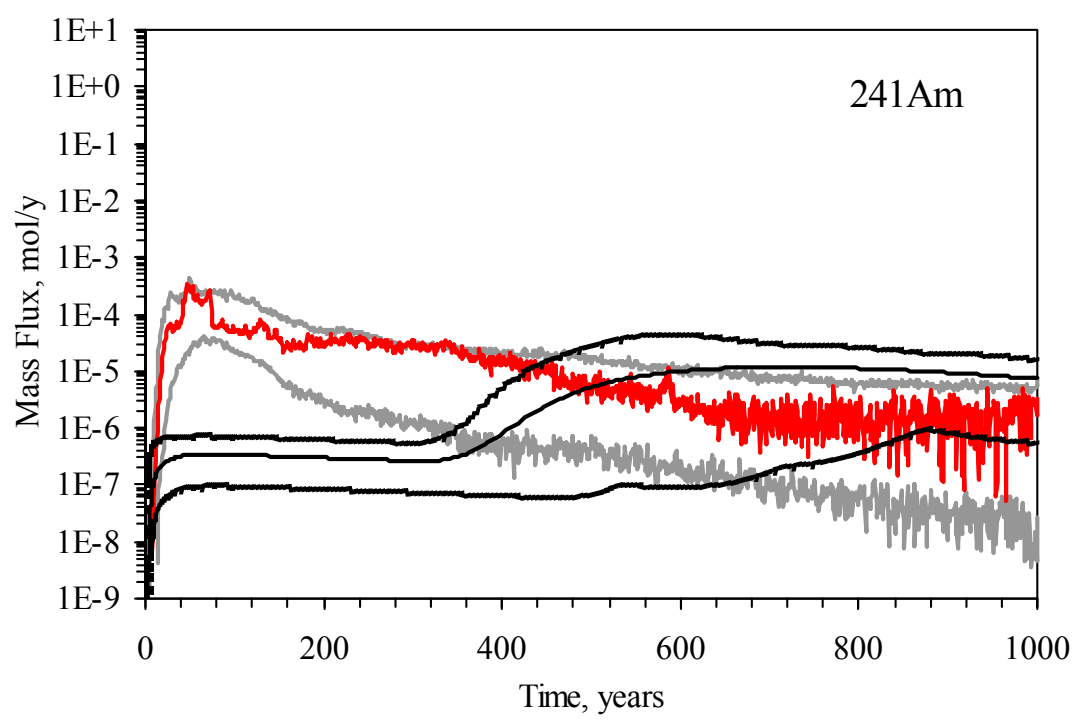

Figure D.2-21

Comparison of ${ }^{241} \mathrm{Am}$ Exit Mass Fluxes from the Process Model with the SSM

Particle model results: mean (red), 5th and 95th percentiles (grey); SSM results: mean (solid black), maximum and minimum (dashed black) 


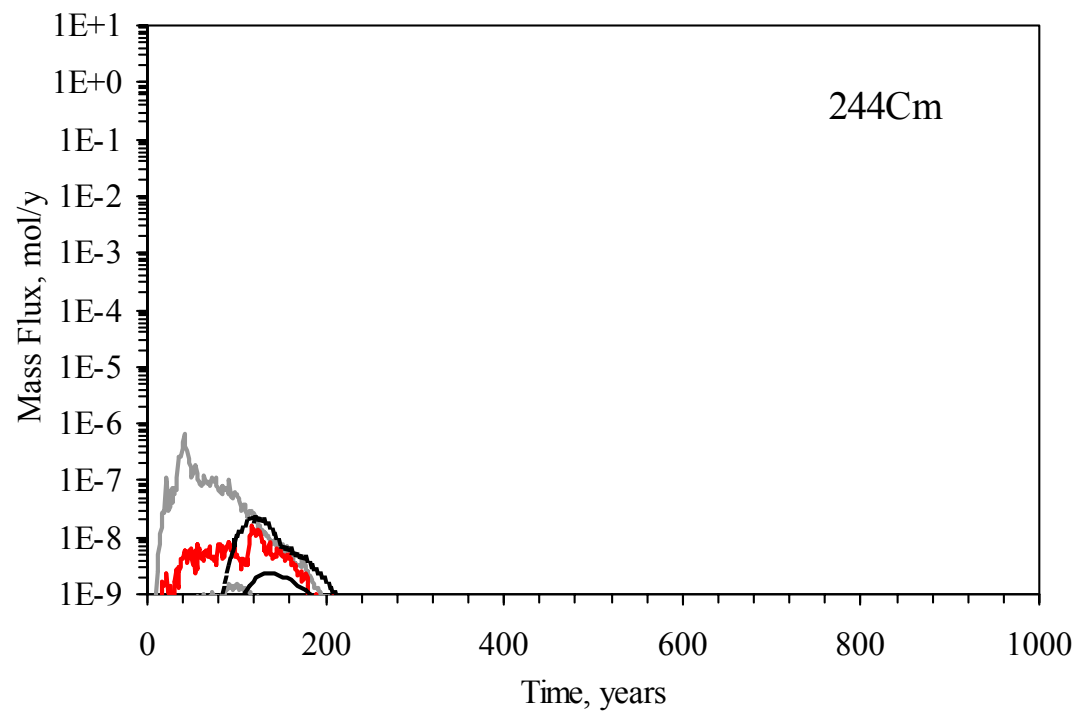

Figure D.2-22

Comparison of ${ }^{244} \mathrm{Cm}$ Exit Mass Fluxes from the Process Model with the SSM

Particle model results: mean (red), 5th and 95th percentiles (grey); SSM results: mean (solid black), maximum and minimum (dashed black) 


\section{Distribution}

State of Nevada

Bureau of Federal Facilities

Division of Environmental Protection

333 W. Nye Lane, Room 138

Carson City, NV 89706-0851

State of Nevada

Bureau of Federal Facilities

Division of Environmental Protection

1771 E. Flamingo Road, Suite 121-A

Las Vegas, NV 89119

R. M. Bangerter, Jr.

Environmental Restoration Division

U.S. Department of Energy

National Nuclear Security Administration

Nevada Site Office

P.O. Box 98518, M/S 505

Las Vegas, NV 89193-8518

W. R. Wilborn

Environmental Restoration Division

U.S. Department of Energy

National Nuclear Security Administration

Nevada Site Office

P.O. Box 98518, M/S 505

Las Vegas, NV 89193-8518

J. P. McCord

Stoller-Navarro Joint Venture

7710 W. Cheyenne Ave. Bldg. 3

Las Vegas, NV 89129

B. J. Deshler

Stoller-Navarro Joint Venture

1 (electronic copy)

7710 W. Cheyenne Ave. Bldg. 3

Las Vegas, NV 89129

J. A. Wurtz

1 (electronic copy)

Stoller-Navarro Joint Venture

(electronic copy)

7710 W. Cheyenne Ave. Bldg. 3

Las Vegas, NV 89129

G. J. Ruskauff

1 (electronic copy)

Stoller-Navarro Joint Venture

7710 W. Cheyenne Ave. Bldg. 3

Las Vegas, NV 89129 
J. I. Daniels

Lawrence Livermore National Laboratory

P.O. Box 808, L-396

Livermore, CA 94551

G. A. Pawloski

Lawrence Livermore National Laboratory

P.O. Box 808, L-231

Livermore, CA 94551

T. P. Rose

Lawrence Livermore National Laboratory

P.O. Box 808, L-221

Livermore, CA 94551

A. B. Kersting

Lawrence Livermore National Laboratory

P.O. Box 808, L-231

Livermore, CA 94551

R. M. Maxwell

Lawrence Livermore National Laboratory

P.O. Box 808, L-204

Livermore, CA 94551

\section{A. Tompson}

Lawrence Livermore National Laboratory

P.O. Box 808, L-204

Livermore, CA 94551

M. Zavarin

Lawrence Livermore National Laboratory

P.O. Box 808, L-231

Livermore, CA 94550

N. M. Becker

Los Alamos National Laboratory

P.O. Box 1663, M/S F665

Los Alamos, NM 87545

D. L. Finnegan

Los Alamos National Laboratory

P.O. Box 1663, M/S 462

Los Alamos, NM 87545

E. M. Kwicklis

Los Alamos National Laboratory

P.O. Box 1663, M/S T003

Los Alamos, NM 87545
1 (electronic copy)

1

1

1 (electronic copy)

1 (electronic copy)

1 (electronic copy)

1 (electronic copy)

1

1 (electronic copy)

1 (electronic copy) 
W. L. Hawkins

Los Alamos National Laboratory

P.O. Box 1663, M/S 462

Los Alamos, NM 87545

A. V. Wolfsberg

Los Alamos National Laboratory

P.O. Box 1663, M/S 649

Los Alamos, NM 87545

P. W. Reimus

Los Alamos National Laboratory

P.O. Box 1663, M/S J-534 CST-7

Los Alamos, NM 87545

H. J. Turin

Los Alamos National Laboratory

P.O. Box 1663, M/S J514

Los Alamos, NM 87545

P. K. Ortego

Bechtel Nevada

P.O. Box 98521, M/S NLV082

Las Vegas, NV 89193-8521

S. L. Drellack

Bechtel Nevada

P.O. Box 98521, M/S NLV082

Las Vegas, NV 89193-8521

V. Yucel

Bechtel Nevada

P.O. Box 98521, M/S NLV081

Las Vegas, NV 89193-8521

C. E. Russell

Desert Research Institute

755 E. Flamingo Road

Las Vegas, NV 89132-0040

G. M. Pohll

Desert Research Institute

755 E. Flamingo Road

Las Vegas, NV 89132-0040

R. L. Jacobson

Desert Research Institute

2215 Raggio Parkway

Reno, NV 89512
1 (electronic copy)

1 (electronic copy)

1 (electronic copy)

1 (electronic copy)

1

1 (electronic copy)

1 (electronic copy)

1

1 (electronic copy)

1 (electronic copy) 
J. M. Thomas

Desert Research Institute

2215 Raggio Parkway

Reno, NV 89512

R. K. Waddell

GeoTrans

363 Centennial Parkway, Suite 210

Louisville, CO 80030

R. J. Laczniak

U.S. Geological Survey

160 N. Stephanie St.

Henderson, NV 89074

B. K. Thompson

U.S. Geological Survey

160 N. Stephanie St.

Henderson, NV 89074

R. P. Graves

U.S. Geological Survey

160 N. Stephanie St.

Henderson, NV 89074

D. E. Prudic

U.S. Geological Survey

333 West Nye Lane, Room 203

Carson City, NV 89706

E. H. McKee

U.S. Geological Survey

345 Middlefield Road, MS 975

Menlo Park, CA 94025

Z. E. Peterman

U.S. Geological Survey

Denver Federal Center

21 Center Ave., MS 963

Lakewood, CO 80225

U.S. Department of Energy

National Nuclear Security Administration

Nevada Site Office Technical Library

P.O. Box $98518, \mathrm{M} / \mathrm{S} 505$

Las Vegas, NV 89193-8518

U.S. Department of Energy

Office of Scientific and Technical Information

P.O. Box 62

Oak Ridge, TN 37831-0062
1 (electronic copy)

1 (electronic copy)

1 (electronic copy)

1

1 (electronic copy)

1 (electronic copy)

1 (electronic copy)

1 (electronic copy)

1

1 (electronic copy) 
Southern Nevada Public Reading Facility

c/o Nuclear Testing Archive

P.O. Box $98521, \mathrm{M} / \mathrm{S} 400$

Las Vegas, NV 89193-8521

Manager, Northern Nevada FFACO

Public Reading Facility

c/o Nevada State Library \& Archives

Carson City, NV 89701-4285

Central Files

Stoller-Navarro Joint Venture

7710 W. Cheyenne Ave. M/S 439

Las Vegas, NV 89129 